HENRIQUE ALESSANDRO DE ALMEIDA RAMOS

Avaliação da Influência da Infraestrutura de Transporte nas Mudanças de Uso e Cobertura da Terra através de Modelagem Dinâmica Espacial

V.1 
HENRIQUE ALESSANDRO DE ALMEIDA RAMOS

\title{
Avaliação da Influência da Infraestrutura de Transporte nas Mudanças de Uso e Cobertura da Terra através de Modelagem Dinâmica Espacial
}

\begin{abstract}
Dissertação apresentada ao Programa de PósGraduação em Engenharia de Transportes da Escola Politécnica, Universidade de São Paulo, como parte dos requisitos para obtenção do título de Mestre em Ciências
\end{abstract}

Área de Concentração: Engenharia de Transportes - Informações Espaciais

Orientadora: Prof. $\underline{\text { a }}$ Dr. ${ }^{\text {a }}$ Mariana Abrantes Giannotti

Co-orientadora: Prof. $\underline{a}$ Dr. ${ }^{a}$ Cláudia Maria de Almeida 
Este exemplar foi revisado e corrigido em relação à versão original, sob responsabilidade única do autor e com a anuência de seu orientador.

São Paulo, de de

Assinatura do autor:

Assinatura do orientador:

\section{Catalogação-na-publicação}

Ramos, Henrique Alessandro de Almeira

Avaliação da Influência da Infraestrutura de Transporte nas Mudanças de Uso e Cobertura da Terra através de Modelagem Dinâmica Espacial / H. A. A. Ramos -- versão corr. -- São Paulo, 2017.

$167 \mathrm{p}$.

Dissertação (Mestrado) - Escola Politécnica da Universidade de São Paulo. Departamento de Engenharia de Transportes.

1.Modelagem Dinâmica 2.Cobertura do Solo 3.Dinamica-EGO 4.Guarulhos I.Universidade de São Paulo. Escola Politécnica. Departamento de Engenharia de Transportes II.t. 
Dedico este trabalho à minha mãe, que muito cedo acumulou a função de pai. 


\section{Agradecimentos}

Frequentemente a seção de agradecimentos é última parte a ser escrita, felizmente sem a aspiração ao rigor e a frieza necessários ao restante do texto. No entanto, não deixa de ser a escrita mais difícil, dada a rede de pessoas envolvidas para tornar a pesquisa uma realidade, seja direta ou indiretamente, ao longo do tempo na pós-graduação.

Desta forma, inicialmente agradeço aos meus professores, sobretudo aqueles que estiveram preocupados em fazer da faculdade um ambiente propício ao estudo e à reflexão. Faço um agradecimento especial à Mariana e à Claudia, orientadora e co-orientadora deste trabalho, e que tornaram tudo isso possível, com a sugestão do tema, elucidação do modelo, sugestões de leituras e inúmeras reuniões.

Também um agradecimento importante deve ser dirigido à Universidade de Guarulhos, que nas pessoas dos Profs. Antonio R. Saad e Anderson T. Ferreira, forneceu as imagens do município de Guarulhos, sem as quais não poderíamos ter realizado os mapas de cobertura e uso do solo.

A Universidade Federal de Minas Gerais (UFMG) que forneceu um curso sobre - Dinamica-EGO que foi de grande estima para o início dos trabalhos com a modelagem, e particularmente ao Prof. Wiliam Leles por ministrar o curso.

Aos professores Rodrigo Nóbrega (UFMG) e Karin Marins (USP), cujas contribuições durante a banca de qualificação foram de especial importância para agregar conteúdo e deixar o trabalho mais robusto.

Não menos importante é o agradecimento aos funcionários da faculdade em geral, que cumprem suas funções administrativas e, fazendo isso com alegria, tornam o ambiente acadêmico mais acolhedor.

Por fim, agradeço aos colegas de sala do mestrado e aos amigos da vida. Sem estes não há tanto motivo para continuar. Em particular à Marina, por traduzir os textos em inglês e a Malu por revisar o texto na reta final. Escrever este texto traz uma particular vontade de reencontra-los, para além dos compromissos do mestrado.

Sou grato à família e a Mariana, por incentivarem a entrar no curso do mestrado e, com certeza mais importante, por convencer e insistir para não sair!

Agradeço, enfim, à Universidade de São Paulo por contas das oportunidades que tive ao longo desta jornada. 


\section{Resumo}

A dinâmica das paisagens e as consequentes alterações no uso e cobertura da terra podem ser analisadas a partir de modelagens espaciais, que auxiliam na interpretação das variáveis responsáveis pelas alterações na paisagem, bem como viabilizam a criação de cenários distintos visando ao conhecimento do impacto produzido pela inserção ou supressão de variáveis na simulação de mudanças da paisagem.

Em Guarulhos, a instalação de grandes rodovias conectando o município de São Paulo ao Vale do Paraíba e, posteriormente, de um terminal aeroportuário, em consonância com diferentes períodos de crescimento econômico e expansão urbana, impactaram fortemente na formação da paisagem encontrada neste município, principalmente com a instalação dos grandes pátios industriais e bairros residenciais de média e baixa renda.

Com isso, a presente pesquisa buscou avaliar as mudanças no uso e cobertura da terra a partir de produtos de sensoriamento remoto para identificar a influência advinda da instalação dos grandes pontos de conexão do município, por meio de modelagem com autômatos celulares (cellular automata - CA).

Dentre os principais resultados obtidos está a influência positiva nas transições para a classe residencial regular exercida pela instalação do aeroporto no primeiro período de análise (1986 a 1993), e a repelência a essa transição nos anos seguintes. Resultados similares foram obtidos na avaliação da influência das grandes vias de acesso na implantação dos parques industriais e galpões logísticos. A modelagem dinâmica, por meio do software DinamicaEGO, mostrou-se uma ferramenta bastante versátil para avaliação da influência das variáveis espaciais na dinâmica das paisagens urbanas.

Palavras-chave: Guarulhos; Dinamica-EGO; Modelagem Dinâmica; Cobertura e Uso da Terra. 


\begin{abstract}
The dynamics of landscapes and the consequent changes in land use and land cover can be analyzed according to spatial models, which helps the interpretation of the variables responsible for territorial changes, as well as enables the creation of distinct scenarios in order to know the impact produced by the insertion or suppression of variables in the simulation of landscape changes.
\end{abstract}

In the municipal area of Guarulhos, the installation of large highways linking the municipality of São Paulo to the Paraíba Valley and an airport terminal afterwards, in accordance with different periods of economic growth and urban expansion, had a strong impact on the landscape found in this municipality, mostly because of the installation of large industrial yards and residential neighborhoods of medium and low income.

Hence, this research aimed to evaluate the changes in land use and land cover according to remote sensing products, and it also aimed to try to identify the influence of the installation of big connection points of the municipality through modeling with cellular automata (CA).

Among the main results obtained are the positive influence on the transitions to the regular residential class exercised by the airport installation in the first period of analysis (1986 to 1993), and the repellency of this transition in the following years. A similar result was obtained in the evaluation of the influence of the great access roads in the implantation of industrial parks and logistic sheds. Thus, the dynamic modeling through the Dynamica-EGO software proved to be a very versatile tool to evaluate the influence of spatial variables on the dynamics of urban landscapes.

Keywords: Guarulhos; Dynamica-EGO; Dynamic Modeling; Land Cover and Land Use. 


\section{Sumário}

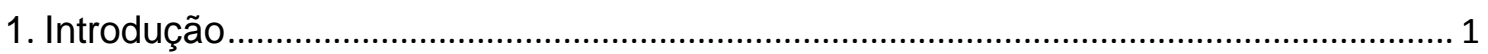

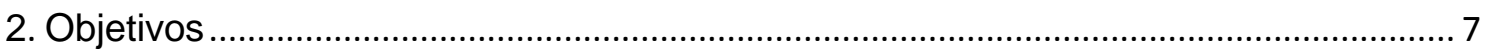

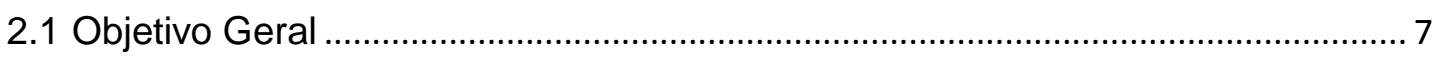

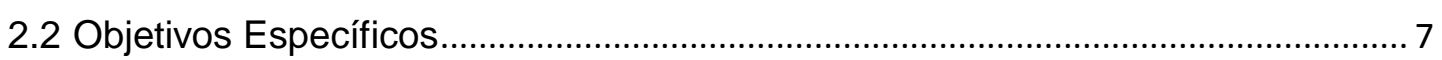

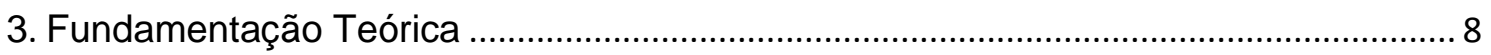

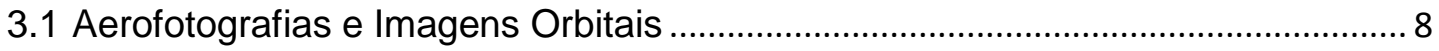

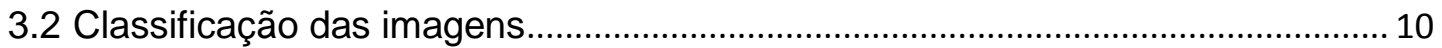

3.3 Avaliação da Classificação e Índice Kappa................................................................ 11

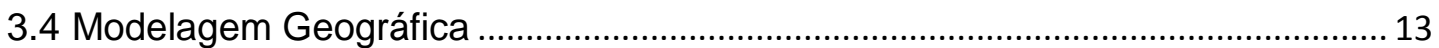

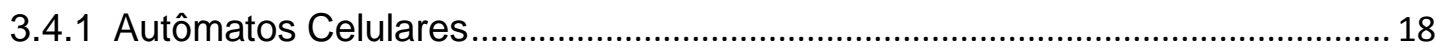

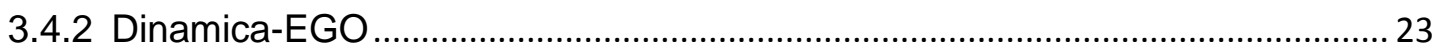

3.5 Sistemas de Transportes e Mudanças na Cobertura do Solo................................ 27

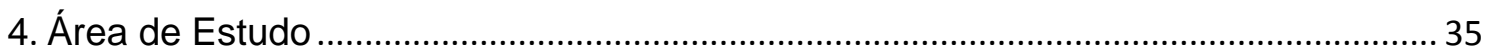

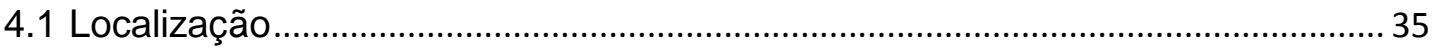

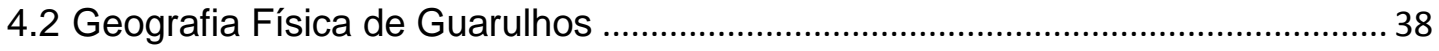

4.3 Aspectos Históricos e Geografia Humana de Guarulhos....................................... 42

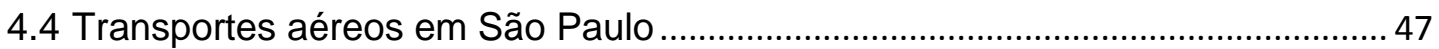

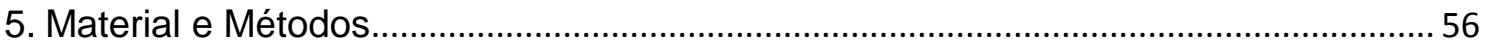

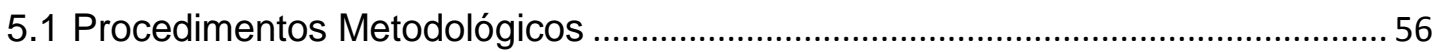

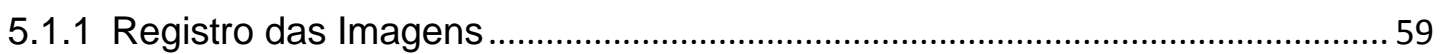

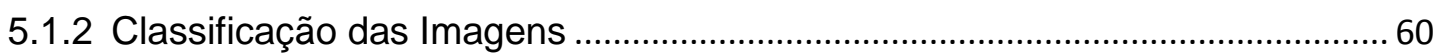

5.1.3 Organização e Processamento da Base de Dados ............................................63

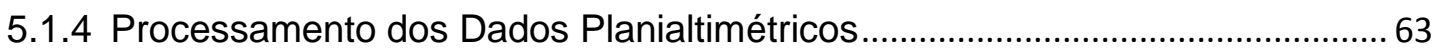

5.1.5 Processamentos dos Dados Vetoriais Temáticos ................................................ 64

5.1.6 Conversão das Classificações de Cobertura e Uso da Terra .............................. 64

5.1.7 Etapas de Construção do Modelo no Dinamica-EGO ......................................... 65

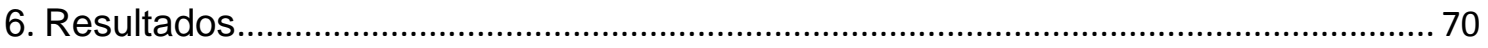

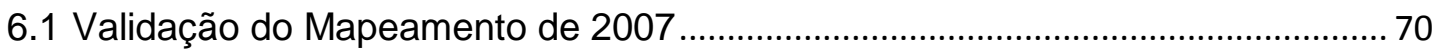

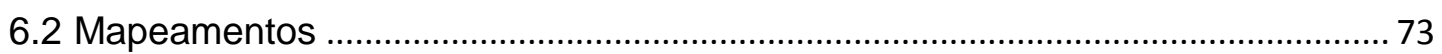

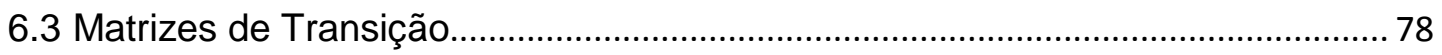

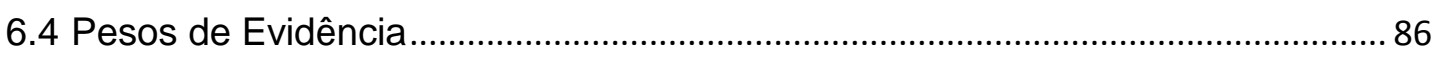


6.4.1 Transição de Loteamento Desocupado para Urbano Regular............................ 86

6.4.2 Transição de Campo / Capoeira para Urbano Regular ........................................ 92

6.4.3 Transição de Loteamento Desocupado para Urbano Irregular ........................... 98

6.4.4 Transição de Loteamento desocupado para Indústrias/ Galpões ................... 103

6.5 Considerações sobre os Mapeamentos, Matrizes de Transição e Pesos de

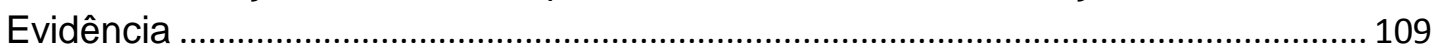

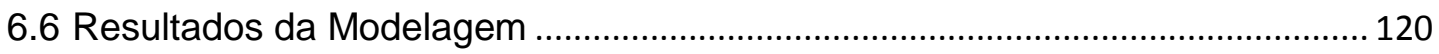

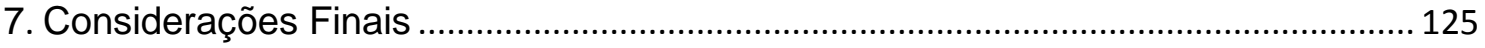

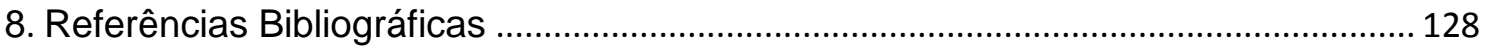




\section{Introdução}

A partir da revolução industrial ocorrida na Europa no final do século XVIII, a população mundial vem se tornando cada vez mais partícipe de profundas transformações da paisagem e do estilo de vida como um todo. Uma das características mais marcantes deste processo, senão o principal fenômeno, é o deslocamento populacional em direção às cidades em busca dos empregos gerados através das novas relações de trabalho.

Tais movimentos migratórios, o êxodo rural, teve início na Europa, concomitantes ao surgimento das primeiras industrias modernas e, à medida que a industrialização atingiu outras partes do mundo, estes movimentos foram ficando comuns também em outros países e continentes, sendo especialmente importantes na segunda metade do século XIX e ao longo do século XX.

De acordo com relatório da ONU (2014), a proporção da população urbana no mundo passou de 29,6\% em 1950 para 42,9\% em 1990 e 51,6\% no ano de 2015. Na América Latina essa proporção atingiu níveis ainda maiores, onde se constata que em 1950 a região possuía $40 \%$ da população em áreas urbanas e atingiu quase 80\% no início da década de 2010 (ONU, 2012).

Sobre o crescimento das manchas urbanas, foi realizado um estudo por Tautenböck et al. (2012) com base em imagens orbitais de 1975, 1990, 2000 e 2010 sobre as 27 megacidades existentes no mundo (sendo São Paulo, Rio de Janeiro, Buenos Aires e México as cidades da América Latina). Como resultado os autores constataram que a área urbana nestas localidades vem aumentando em ritmo mais acelerado que a proporção de população urbana mundial.

A concentração espacial de pessoas em áreas urbanas segue os preceitos da economia de aglomeração proposta por Marshall no final do século XIX. Este autor sugere que os agentes produtivos devem estar próximos entre si e também dos agentes consumidores (GALINARI, 2007). Considerando as novas relações de trabalho que passaram a existir após a revolução industrial, principalmente no que se refere à transformação do agente do campo em operário fabril, é possível entender porque as cidades com mais de um milhão 
de habitantes eram apenas duas há dois séculos (Londres e Pequin) e já somam mais de 450 no século XXI, das quais 17 estão localizadas no Brasil.

No caso do Brasil, a migração da população rural para as áreas urbanas ocorreu no século XX, cujas taxas de crescimento foram particularmente aceleradas nas décadas de 1950 e 1970, décadas em que o parque industrial brasileiro passou por grandes transformações. Esse ritmo acelerado de crescimento da população urbana começou a diminuir apenas após o ano de 1990 (ONU, 2012).

De acordo com dados tabulados por Santos (1993), a proporção da população urbana no Brasil era 10,7\% em 1920, eleva-se a 36,2\% em 1950 e atinge 65,1\% em 1980. Dados do censo demográfico do Brasil de 2010 (IBGE, 2011) revelam que das mais de duzentas milhões de pessoas contadas naquele ano, quase $85 \%$ viviam em áreas urbanas.

A urbanização acelerada no Brasil tem suas raízes nos processos de industrialização e mecanização da produção agrícola a partir da década e 1950, que criaram e intensificaram os fluxos de migrações internas, principalmente do Nordeste, Norte e Centro-Oeste em direção às regiões metropolitanas do eixo sul-sudeste que vinham recebendo a implementação dos grandes parques industriais no país, bem como a expressiva redução da mortalidade em decorrência do acesso à medicina moderna (SANTOS, 1993).

No caso particular da Região Metropolitana de São Paulo (RMSP), o crescimento acelerado foi muito bem documentado ao longo do século $\mathrm{XX}$, tanto por meio de documentos cartográficos, quanto por aerolevantamentos e registros cadastrais mantidos por órgãos vinculados às prefeituras como pode ser verificado no estudo conduzido por Meyer et. al. (2008), que resultou no conjunto de mapas apresentado na Figura 1.1 a seguir. 


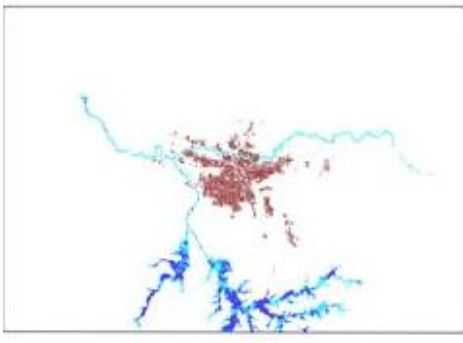

1930

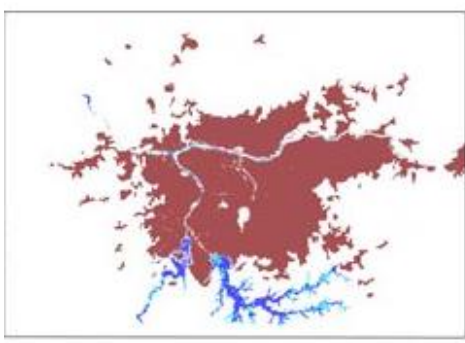

1972

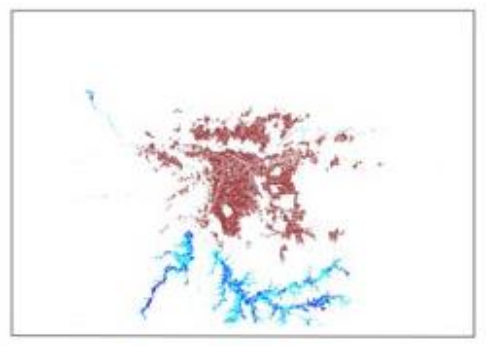

1952

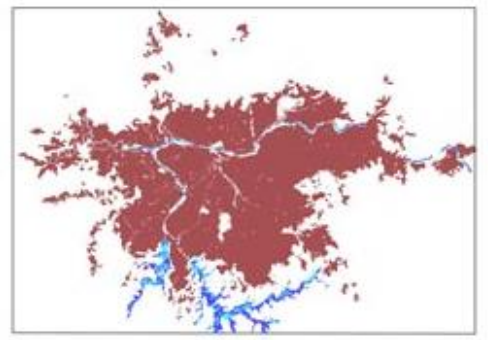

1983

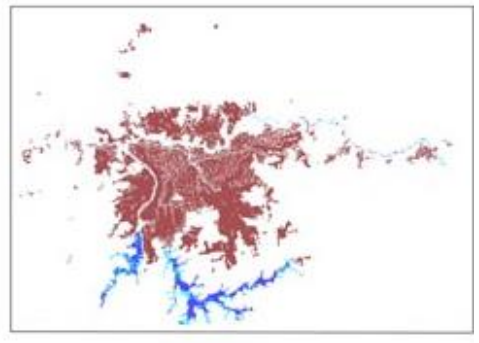

1962

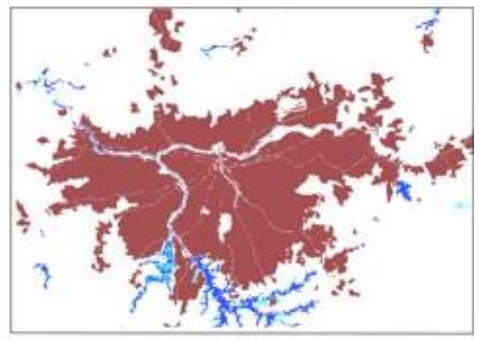

1995

Figura 1.1 - Crescimento Urbano na Região Metropolitana de São Paulo (MEYER et. al., 2008)

Estes mapas apontam para a elevada velocidade com que as áreas urbanas se fixaram e expandiram horizontalmente, atingindo inclusive as cabeceiras dos mananciais localizados na zona sul e conturbando áreas urbanas de diversos municípios da região metropolitana, como pode ser observado.

Sobre o crescimento populacional na RMSP, Marques \& Requena (2013) conduziram um estudo com base em dados censitários para analisar os movimentos populacionais entre os anos de 2000 e 2010. Com base nestes dados os autores constataram que há uma tendência geral de diminuição nas taxas de crescimento populacional da RMSP. No entanto, eles também destacaram a existência de fluxos migratórios dentro dessa região que resultaram em áreas cujo crescimento foi superior à média, ao passo que em outros locais houve uma diminuição significativa da população. Os autores destacaram o forte papel que a melhoria e o acesso aos sistemas de transportes tiveram na localização das populações.

É possível acompanhar o crescimento da RMSP por meio da história de importantes elementos do sistema de transporte, como a substituição dos bondes por ônibus a partir da década de 1920, a inauguração da via 23 de Maio na década de 1960, das rodovias Presidente Dutra (1951), Fernão Dias (1959) 
e Ayrton Senna (1982), dos Aeroportos de Congonhas (1936), Guarulhos (1985) e Viracopos (1960), das estações do metrô das linhas azul e vermelha ao longo da década de 1980 e da linha verde nas décadas de 1990 e 2000, entre outros exemplos.

No que se refere a Guarulhos, é possível destacar que até a década de 1970, foi considerado uma cidade dormitório, e desta década em diante, sobretudo a partir de 1980, passou a sofrer um forte crescimento populacional ensejado pelos preços mais atrativos dos terrenos e domicílios, pelas melhorias nas condições de transporte e pela crescente frota de automóveis disponíveis.

Os motivos para este crescimento populacional também estão conectados ao fato do municipio de São Paulo passar por uma desindustrialização entre as décadas de 1970 e 1980. Parte do parque industrial paulistano foi transferido para o municipio de Guarulhos, principalmente às margens das rodovias que dão acesso ao valor do Paraiba.

Com isso o municipio de Guarulhos viu seu parque industrial crescer rapidamente, e foi graças à ampliação da oferta de empregos diretos e indiretos que passou a exercer atração no contexto da RMSP, criando fluxos de entrada populacional para dentro de seus limites municipais. A inauguração do Aeroporto Internacional de Guarulhos, em 1985, aumenta significativamente a oferta de empregos no setor de serviços e ajuda a consolidar a nova condição de polo economico do município (SANTOS, 1985).

Compreender tais dinâmicas urbanas tem sido o objetivo de diversos pesquisadores, dentre os quais é possível destacar Lasalvia (2006) e Marques \& Requena (2013).

Para auxiliar na compreensão das dinâmicas urbanas, a partir dos anos 1960, a partir da inserção das análises quantitativas nas ciências sociais e o advento do computador pessoal, foram criados modelos urbanos concebidos para o estudo e planejamento de determinados aspectos do ambiente urbano, como os transportes, localização espacial de atividades comerciais e industriais, mudanças de uso do solo urbano, entre outros temas. 
Avanços consideráveis em modelagem urbana e de mudanças da paisagem em geral começam a ocorrer na década de 1980, com a popularização dos sistemas computacionais e o nascimento da computação gráfica. Modelos dinâmicos espaciais, ou assim chamados modelos espacialmente explícitos, surgem a partir de então, permitindo a representação de fenômenos dotados de dimensão temporal e espacial (LONGLEY et al. 2011).

O principal objetivo desses modelos é tornar possível a simulação númerica de processos do mundo real, sempre que o estado de um ponto na superfície muda em função de suas forças direcionadoras (BURROUGH, 1998).

Alguns pesquisadores estudaram especificamente a relação das alterações na cobertura e uso da terra com as modificações e adensamento das malhas pertencentes aos sistemas de transportes e terminais logísticos.

No contexto do planejamento urbano, a modelagem invariavelmente contribui através do estudo de prognósticos de diferentes alternativas de uso e facilidades de acesso, revelando sua importância no estudo e planejamento urbano.

Um software de simulação aplicado ao estudo das alterações da paisagem que tem sido disseminado na comunidade científica é o DinamicaEGO, que vem sendo desenvolvido desde 1998 pelo Centro de Sensoriamento Remoto da Universidade Federal de Minas Gerais - CSR-UFMG. É um modelo cuja simulação baseia-se nas regras de transição segundo o paradigma de autômatos celulares, o que significa que a paisagem é representada por uma grade regular com celulas discretas, que podem alterar seus estados (no caso, classes de uso ou cobertura da terra) segundo regras de transição universais.

A presente pesquisa utilizou o modelo Dinamica-EGO com dados do município de Guarulhos (principalmente as informações sobre o relevo e o sistema viário) para modelar as transições de uso e cobertura da terra observadas no período entre 1986 e 2007.

Este município é uma área bastante rica para estudos deste tipo, uma vez que se tornou uma cidade com mais de um milhão de habitantes em poucas décadas, tornando-se partícipe direta dos processos relacionados à urbanização 
da RMSP, sendo influenciado e influenciador dos movimentos populacionais em nível metropolitano, regional e macrorregional.

Há um destaque especial para a inauguração e posterior ampliação da Rodovia Presidente Dutra, a inauguração da rodovia Ayrton Senna, a instalação do Aeroporto de Guarulhos, além de outras vias que aumentaram a permeabilidade entre Guarulhos e os municípios limítrofes.

Além disso, o município de Guarulhos possui uma extensa base documental, incluindo mapeamentos, fotografias aéreas, estudos, entre outras bases, tornando-se assim um local adequado para a realização de uma pesquisa cujo intuito é a aplicação do modelo Dinamica-EGO no estudo da influência das vias de acesso no desenvolvimento do município.

O Dinamica-EGO reúne funções de transição baseadas em vizinhança estacionária ou multiescala, retroalimentação espacial, conceitos de fases por meio de processos estocásticos de simulação em etapas, e parametrização por pesos de evidência das mudanças ocorridas na paisagem, destinada a calcular mapas de probabilidade de transição entre classes.

O Dinamica-EGO tem sido amplamente utilizado em simulações de mudanças na cobertura e uso da terra e padrões de desflorestamento, identificação de zonas de transição, entre outros, fornecendo inclusive subsídios para o planejamento urbano (ALMEIDA, 2004). 


\section{Objetivos}

\subsection{Objetivo Geral}

- Avaliar a influência da infraestrutura de transportes, em especial do Aeroporto de Guarulhos e da Rodovia presidente Dutra, nas mudanças de cobertura e uso da terra no município de Guarulhos, por meio de modelagem dinâmica espacial retrospectiva, compreendendo o período de 1986 a 2007.

\subsection{Objetivos Específicos}

- Identificar os processos de mudanças de cobertura e uso da terra por meio de análises multi-temporais e mapas temáticos.

- Avaliar conjuntamente os mapas de uso do solo, as matrizes de transição, os pesos de evidência e os mapas de probabilidade de transição para elucidar as modificações na cobertura do solo de Guarulhos.

- Simular cenários futuros de cobertura e uso da terra a partir da análise dos mapeamentos presente e pretérito, utilizando-se modelagem dinâmica espacial. 


\section{Fundamentação Teórica}

O presente capítulo objetiva realizar uma breve descrição das metodologias utilizadas no decorrer da pesquisa, tanto para realizar o levantamento cartográfico das alterações de cobertura e uso da terra por meio de imagens aéreas e orbitais, como para a execução do modelo dinâmico espacial voltado à quantificação e simulação dessas alterações.

\subsection{Aerofotografias e Imagens Orbitais}

As aerofotografias são uma realidade desde o século XIX, quando a primeira fotografia aérea foi feita a bordo de um balão. Apesar disso, seu uso como um recurso de levantamento cartográfico e temático ocorreu após o aprimoramento das técnicas fotogramétricas durante e após a Segunda Guerra Mundial (JENSEN, 2009).

Possuem destaque para a cartografia as fotografias aéreas verticais que são obtidas por meio de câmeras transportadas em veículos aéreos voando a baixa altitude. Tradicionalmente são aeronaves de pequeno porte que sobrevoam uma região, obtendo imagens pancromáticas ou multiespectrais para coleta de informações, sendo que recentemente tem sido cada vez mais comum o uso de drones.

Dado o uso de uma câmera fotográfica, seja analógica ou digital, um conjunto de especificidades deve ser observado antes da utilização das fotografias para mapeamento. Duas características são marcantes no uso dessa tecnologia. A primeira é que qualquer que seja a lente utilizada na captura da fotografia, ela resultará em uma distorção que será gradativamente maior à medida que se afasta do centro focal. A segunda se refere à perspectiva relacionada à distância vertical entre objetos geográficos, de tal forma que elementos com maior altitude parecerão maiores que objetos de mesmo tamanho, no caso de estarem localizados em altitudes menores (CRÓSTA, 1993).

A correção desses elementos é, portanto, condição fundamental para usar tais imagens como base para mapeamento e criação de produtos cartográficos, e pode ser realizada por meio da ortorretificação das fotografias, que ocorre em 
ambiente computacional. O processo consiste em ordená-las em função do plano de voo, por meio da coordenada do ponto central e orientação, corrigir a distorção da lente por meio da aplicação de algoritmos de transformação, baseados na distância focal e modelo da lente, e correção da perspectiva a partir de um modelo digital do terreno em função da altitude de voo em cada foto.

Para isso é preciso fornecer os metadados das fotografias, ou seja, coordenada central, distância focal e modelo da lente, altitude de voo para cada cena e juntar a isso um modelo digital do terreno. Em levantamentos modernos, cuja saída é um arquivo digital, tais informações são gravadas diretamente nos arquivos de saída, tornando mais fácil a leitura pelos softwares que farão 0 processamento.

Contudo, em muitos levantamentos mais antigas tais informações não estão disponíveis, seja por que não existiam quando foram feitos (caso da coordenada central de cada foto quando não havia sistemas de posicionamento), seja porque se perderam por algum motivo. Tais problemas são particularmente comuns em coleções antigas de aerofotografias

Nesses casos, as fotografias poderão ainda ser utilizadas em algumas situações, como as restituições 3D, por exemplo. Também podem ser usadas para atualizar mapas existentes, já que permitem ao analista verificar a situação de ocupação dos lotes, a supressão ou não da vegetação em uma gleba, ou se uma determinada indústria foi construída ou demolida na passagem dos anos.

Além das fotografias aéreas, desde a década de 1970 estão disponíveis os satélites de observação da terra, de tal forma que a cada ano é ampliada a constelação de sistemas sensores, bem como as resoluções espacial, radiométrica, temporal e espectral das imagens por eles geradas. Atualmente já estão disponíveis imagens com taxa de retorno de 8 ou 16 dias, resolução espacial submétrica, uma grande variedade de bandas espectrais e resolução radiométrica superior a 16 bits para cada banda (JENSEN, 2009).

Segundo Jensen (2009), os sensores transportados pelos satélites possuem uma característica importante no que trata da perspectiva, já que os satélites onde são transportados os sensores estão a centenas de quilômetros 
de altitude (o lkonos, por exemplo, encontra-se a $681 \mathrm{~km}$ acima da terra), o que causa uma drástica redução das distorções causadas pela perspectiva. Além disso, a coleta da imagem do satélite não é feita de modo instantâneo, mas por varredura, o que também reduz os problemas decorrentes das lentes.

Atualmente, em estudos multitemporais, essas duas tecnologias podem ser combinadas a partir da integração de informações obtidas em períodos distintos, tornando possível realizar estes estudos baseados em aerofotografias da década de 1960, ou anteriores, combinadas com imagens orbitais mais recentes.

\subsection{Classificação das imagens}

A ação humana sobre o espaço materializa-se em um mosaico de coberturas distintas, criando paisagens de diferentes complexidades, com aspectos normalmente definidos pelo tipo de atividade desenvolvida tais como as áreas agrícolas, urbanas, florestais, industriais, entre outros.

Com isso, a paisagem é uma categoria tradicional de análise na geografia, e a elaboração de mapas de cobertura e uso da terra torna-se uma etapa primordial nestes estudos. Principalmente a partir da segunda metade do século $X X$, é uma tarefa normalmente efetuada com auxílio de aerofotografias ou imagens orbitais, tratadas em ambiente computacional (JENSEN, 2009).

Segundo o IBGE (2006), o ato de classificar é agrupar objetos, elementos e eventos em conjuntos pré-definidos mais ou menos homogêneos, tomando por base suas propriedades e características. Tais abstrações têm como objetivo atender a certos objetivos de pesquisa ou às necessidades do usuário.

Durante a etapa de planejamento do mapeamento de cobertura e uso da terra, é muito importante realizar um esforço para conceber um sistema adequado de cobertura e uso da terra, seja utilizando a adaptação de um sistema já existente, caso do sistema proposto por Anderson et al. (1979), programa CORINE (BÜTTNER et al., 2002), Monteiro (2008) e IBGE (2006), seja por meio da criação de um sistema inteiramente novo, baseado nas necessidades do projeto. 
Independente do sistema adotado, é importante que as classes sejam mutuamente exclusivas, isto é, qualquer área classificada deve pertencer a apenas uma classe e nenhuma outra. É importante destacar que esta máxima se refere a uma escala específica, pois é particularmente útil adotar uma organização hierarquizada das unidades, de tal forma que, a título ilustrativo, classes distintas na escala de 1:10.000 pertençam a uma classe menos detalhada na escala 1:100.000, por exemplo. Assim, em caráter exemplificativo, as classes de mata ciliar e vegetação semidecidual na escala 1:50.000, corresponderão apenas à vegetação na escala 1:100.000 (CONGALTON, 1991).

Para os mapeamentos utilizados em modelagem, é importante atentar para a escala do mapeamento, que deve ser condizente com a classe a ser modelada e com os níveis hierárquicos, que permite a adequada organização das classes de interesse e condizem com a estruturação das paisagens (PRADO; GALO, 2010).

De acordo com Monteiro (2008), as aerofotografias frequentemente se prestam a classificações de cobertura do solo em grandes escalas, tais como 1:5.000 ou maior, porém são limitadas quanto à possibilidade de automatização dos processos. Igualmente, as imagens de alta resolução se mostraram adequadas na obtenção de mapeamentos na ordem de 1:10.000, para as quais se utilizam, por exemplo, as imagens obtidas pelo satélite Ikonos-2.

Segundo este autor, pesquisas que buscam obter a dinâmica intraurbana precisam lidar com estes mapeamentos de detalhe, com os quais é possível, por exemplo, extrair a disposição de classes que tem uma distribuição frequentemente pequena, como por exemplo as pequenas indústrias e loteamentos irregulares.

\subsection{Avaliação da Classificação e Índice Kappa}

Qualquer mapeamento deve ser submetido a uma avaliação que quantifique a acurácia, precisão e exatidão, além de falhas de comissão e omissão, fornecendo como resultado um valor que indica o grau de confiabilidade de um determinado produto. 
Diversos coeficientes podem ser utilizados com este objetivo. Antunes \& Lingnau (1997) compararam o coeficiente de concordância total, o coeficiente de concordância Tau e o índice Kappa relativos a determinados mapas temáticos e concluíram que este coeficiente é mais adequado para avaliar os mapas de cobertura e uso da terra, justamente por quantificar os erros de comissão e omissão para cada classe mapeada.

O índice Kappa, proposto por Cohen (1960), vem sendo amplamente utilizado na validação de mapas de cobertura e uso do solo, sendo apresentado na Equação 3.1 a seguir.

$$
k=\frac{P_{0}-P_{e}}{1-P_{e}} \quad,
$$

em que $P_{0}$ é a taxa de aceitação relativa e $P_{e}$ é a taxa hipotética de aceitação. Estas variáveis baseiam-se em uma matriz de confusão construída com base em pontos amostrais do mapeamento realizado e de pontos obtidos em campo ou a partir de um mapa de referência ou imagem de melhor resolução, como apresentado na Tabela 3.1 a seguir:

\begin{tabular}{|c|c|c|c|c|c|}
\cline { 3 - 6 } \multicolumn{2}{c|}{} & \multicolumn{4}{c|}{ Obtido por realidade de campo } \\
\cline { 3 - 7 } \multicolumn{2}{c|}{} & Classe A & Classe B & Classe C & Total \\
\hline \multirow{3}{*}{$\begin{array}{c}\text { Obtido por } \\
\text { classificação }\end{array}$} & Classe A & 20 & 5 & 3 & 28 \\
\cline { 2 - 6 } & Classe B & 3 & 23 & 7 & 33 \\
\cline { 2 - 6 } & Classe C & 4 & 21 & 8 & 33 \\
\cline { 2 - 6 } & Total & 27 & 49 & 18 & 94 \\
\hline
\end{tabular}

Tabela 3.1 - Matriz de confusão para o cálculo do índice de Kappa

Congalton (1991) enfatiza a importância de se utilizar dados independentes para avaliação do mapa, de modo a eliminar as possibilidades de superestimar a precisão da classificação. Em linhas gerais, o autor sugere que a fonte dos dados de verdade de campo seja obtida por meios que não incluam a imagem classificada e tampouco o mapeamento realizado, pois do contrário incorrer-se-ía na inserção de um dado enviesado.

Normalmente, a matriz representa os dados de referência na coluna e a classificação a ser conferida nas linhas. A exatidão global é obtida com a divisão da soma de pixels corretamente classificados pelo total de pixels da imagem. Se 
a totalidade deles estiver correta, atinge-se o valor máximo e ao mapa é atribuída a confiabilidade de $100 \%$.

Para facilitar a compreensão dos resultados obtidos por meio do índice Kappa, Landis \& Koch (1977) criaram as classes de interpretação dispostas na Tabela 3.2:

\begin{tabular}{|c|c|}
\hline Valores do Índice Kappa & Interpretação \\
\hline$<0$ & Quase inexistente \\
\hline $0-0.19$ & Pequena \\
\hline $0.20-0.39$ & Insatisfatória \\
\hline $0.40-0.59$ & Satisfatória \\
\hline $0.60-0.79$ & Substancial \\
\hline $0.80-1.00$ & Quase perfeita \\
\hline
\end{tabular}

Tabela 3.2 - Classes de interpretação do índice Kappa (LANDIS; KOCH, 1977).

O método inclui a dispersão de pontos aleatórios sobre as classes a serem avaliadas. Para cada ponto, deve ser levantada a verdade de campo e o valor obtido por meio da classificação. Congalton (1991) sugere que sejam coletadas pelo menos 50 amostras para cada classe de cobertura ou uso da terra.

\subsection{Modelagem Geográfica}

Dado que o estudo da evolução da paisagem urbana no município de Guarulhos nas últimas décadas será realizado por meio da modelagem de mudanças de uso e cobertura da terra, torna-se relevante detalhar os conceitos e definições no escopo deste tema.

Tradicionalmente os sistemas de informações geográficas constituem tecnologias para armazenar, recuperar e modificar informações relativas ao espaço, lidando com elas de maneira estática. Contudo, está maneira de representar os elementos geográficas não consegue prover maneiras eficientes de lidar com fenômenos dinâmicos, como os processos físicos do relevo e do clima ou a dinâmica populacional. Com isso, os modelos têm sido uma saída para tentar representar estes fenômenos, e com isso transcender o caráter estático e bidimensional das tradicionais tecnologias de geoprocessamento (PEDROSA; CAMARA, 2007).

Ao lidar com aspectos do mundo real lida-se com problemas infinitamente complexos, para os quais não se pode compreender ou modelar em sua 
totalidade, ou seja, em sua dimensão mais completa. Isso é uma caraterística de qualquer fenômeno físico ou social, dada a quantidade de variáveis envolvidas, das diferentes escalas espaço-temporais possíveis em uma determinada análise.

Para Chorley \& Hagget (1975), diante deste mundo caótico e complexo, a reação natural do ser humano é buscar a simplificação, decompondo-o em partes menores, por meio de criatividade intelectual e experimentação sensorial. Esta é a base do desenvolvimento da ciência moderna.

Os modelos geográficos são estruturações simplificadas da realidade e apresentam as características ou relações importantes e direcionadoras em um determinado fenômeno. Sua utilidade reside justamente na capacidade de esmaecer elementos menos importantes e elucidar os aspectos mais fundamentais de uma forma mais generalizada (CHORLEY; HAGGET, 1975).

É bastante comum aparecer associado aos modelos o processo de "simulação" que, em termos gerais, se refere à condução de experiências sobre um dado modelo para estudar seu comportamento a partir de dados obtidos do mundo real.

Para Chiwft \& Medina (2005) é importante definir aquilo que um modelo não é. Para eles um modelo não é bola de cristal, no sentido de não permitir qualquer tipo de previsão do futuro; o modelo não é uma ferramenta estrita para otimização, e detacam com isso o papel que os modelos ocupam para conduzir estudos sobre os fenomenos; e, por fim, os modelos não são capazes de substituir o pensamento inteligente, o que destaca a necessidade de compreender os dados de entrada e o comportamento deles nos resultados.

Estes autores descrevem os modelos como uma maneira de analisar cenários distintos, baseando-se em uma série de premissas e em um conjunto de dados de entrada obtidos na realidade, sendo o ser humano o elemento mediador entre os aspectos de entrada e as premissas modeladas. Na mesma linha de raciocínio, Longley et al. (2011) afirmam que os modelos ajudam a responder perguntas do tipo "o que ocorre se", o que permite aos usuários 
visualizar as respostas ocorridas em função da modificiação de variáveis e parametros de entrada de um dado modelo.

Nesse sentido, como os modelos permitem uma larga produção de resultados sobre um determinado cenário tornam-se uma maneira muito menos custosa para avaliar uma intervenção, e com isso são largamente utilizados em processos de tomada de decisão (LONGLEY et al., 2011).

Echenique (1968) e Novaes (1981) destacam os seguintes tipos de modelos:

- modelo descritivo, os quais objetivam entender e descrever um dado sistema;

- modelo exploratório, que se caracteriza em um modelo descritivo com análise paramétrica por meio da variação dos estados dos seus elementos constitutivos;

- modelo preditivo, sendo este um modelo exploratório com a inserção da variável tempo e geração de projeção dos dados de entrada;

- modelo operacional, que permite a inserção de dados externos, capazes de modificar suas relações internas;

Christofoletti (1999) divide os modelos em duas categorias principais: a primeira se refere aos modelos análogos naturais, os quais têm a finalidade de elucidar um determinado estudo pela simplificação dos fenômenos, seja por seu viés histórico, como levantamento de ocorrências ao longo de uma linha temporal, seja pelo viés espacial, com base na visão de que o amplo conhecimento de uma paisagem mais simples poderá auxiliar na compreensão de paisagens complexas.

O segundo tipo de modelo descrito por Christofoletti (1999), se refere aos modelos análogos abstratos que se baseiam na ideia de que a compreensão do problema pode ser realizada por meio da análise da estrutura do sistema envolvido. Para isso utilizam-se de desenhos experimentais e modelos matemáticos, dentre os quais se pode citar os modelos determinísticos, baseados em teorias e noções matemáticas precisas, e os modelos probabilísticos ou estocásticos, cuja característica principal é a organização dos dados em expressões que envolvem variáveis, constantes e parâmetros com componentes aleatórios com flutuações imprevisíveis. 
Segundo Couclelis (1997) o avanço tecnológico engendrado no campo computacional a partir da segunda metade do século XX, principalmente com a proliferação de computadores, possibilitou um rápido desenvolvimento na ciência de informações geográficas, de tal forma que tornou possível transcender as clássicas representações de fenômenos reais em formato estático, partindo para a representação dinâmica de fenômenos.

Para ele alguns elementos da representação estática que precisam se flexibilizados para que possa haver a representação dinâmica. Nesse sentido, podemos destacar os seguintes elementos: o espaço, que é uma categoria central nas análises geográficas, deve ser considerado como uma entidade heterogênea, que sofre alterações ao longo do tempo, tanto em suas propriedades como em suas estruturas. As vizinhanças entre os elementos não podem ser estacionárias e as regras de transição não são universais. Além disso, a variação do tempo como um processo regular ou irregular deverá ser contemplada.

De fato, um modelo pode ser denominado dinâmico quando possui uma dimensão temporal explícita, quando as entradas e as saídas do modelo variam com o tempo e quando os estados subsequentes dependem das condições dos estados antecedentes. (WEGENER et al.1986).

Sklar \& Costanza (1990) corroboram esta definição ao categorizar como modelo dinâmico todo aquele que descreve mudanças nos padrões espaciais, de um tempo t para um tempo t+m, tal como expresso na Equação 3.2, a seguir:

$$
X_{t+m}=f\left(X_{t}, Y_{t}\right) \quad, \quad \text { Equação } 3.2
$$

em que

$X_{t}$ é o padrão espacial no tempo t,

$Y_{t}$ é um vetor ou conjunto de variáveis que podem afetar o padrão espacial.

Para estes autores, esta definição deixa implícita a noção da dependência entre espaço e tempo, resultando que tais aspectos não podem ser considerados componentes independentes (SKLAR; COSTANZA,1990). 
Para Soares-Filho et al. (2007), os elementos básicos de qualquer modelo de mudança da paisagem são uma configuração inicial, uma função de mudança e a configuração de saída. Segundo eles a configuração inicial do modelo pode ser um mapa da paisagem, e as funções de mudanças atuam sobre esse mapa a cada passo de tempo. Os resultados sãos os mapas simulados.

Existem modelos dinâmicos capazes de lidar com os mais distintos fenômenos naturais e sociais, nos quais a componente espacial tem sido utilizada como uma das variáveis de entrada. É possível citar os modelos climáticos, de evolução do relevo, hídricos, dispersão de sementes e doenças, de transportes, entre outros. No âmbito deste trabalho serão discutidos os modelos concebidos para lidar com a evolução dos padrões de cobertura do solo.

Para Almeida et. al. (2007) os esforços recentes para compreensão dos fenômenos que atuam sobre as paisagens com o objetivo de transformar tais conhecimentos em uma representação dinâmica delas constituem um dos mais promissores campos de pesquisa das ciências de informações geográficas.

Neste sentido a literatura cientifica tem apresentado um grande número de modelos distintos cujo objetivo é modelar e simular as transições ocorridas entre diferentes classes de cobertura do solo (VERBURG et al., 2006).

Guan et al. (2011) dividiram os modelos utilizados para estudar e simular as alterações ocorridas na cobertura e ocupação do solo em três categorias principais:

- modelos empíricos ou estatísticos, tais como os modelos de regressão e a cadeia de Markov e derivados;

- modelos dinâmicos, que abarcam os modelos baseados em autômatos celulares e modelos baseados em agentes;

- modelos integrados, a exemplo do modelo "Conversão do Uso da Terra e seus Efeitos" (Conversion of Land Use and its Effects - CLUE).

Segundo estes autores os modelos dinâmicos apresentam maior sensibilidade que modelos empíricos ou estatísticos na simulação de mudanças futuras do uso da terra, os quais apresentaram os melhores resultados. 
Um avanço considerável nos modelos utilizados para estes estudos, tanto no refinamento matemático quanto à possibilidade de integrar tais dados com os elementos espaciais ocorreu na década de 1980. Segundo Couclelis (1997) foi quando os modelos baseados em autômatos celulares puderam ser efetivamente modelados espacialmente, graças à ampliação da capacidade de processamento dos computadores, e a partir de então passaram a ser amplamente utilizados em estudos de dinâmica das paisagens, entre elas, a dinâmica de cobertura e uso do solo.

As sub-seção seguinte trata da explanação dos autômatos celulares e dos modelos baseados nesta teoria.

\subsubsection{Autômatos Celulares}

Segundo Pedrosa \& Camara (2007) os autômatos celulares (cellular automata - CA) têm origem no trabalho desenvolvido na década de 1980 por John Conway, que apresentou o "Jogo da Vida", com o qual pôde demostrar que regras bastante simples aplicadas repetidamente sobre estados aleatórios produzem resultados que se assemelham ao comportamento de sistemas orgânicos do mundo real.

Nesse jogo, dado um estado inicial aleatório, a cada passo de tempo, algumas células irão nascer enquanto outras morrerão, sendo que o que determina o estado da célula no instante seguinte é um conjunto de regras, que são avaliadas em função da vizinhança. A Figura 3.1, a seguir, apresenta um jogo da vida no qual há uma vizinhança que será analisada (item a), dois estados possíveis para cada célula, seja ligada ou desligada (item b), um conjunto com regras de transição (item c) e o quadro com as células geradas para o tempo te o resultado da aplicação das regras de transição com a referida vizinha, apresentado para o tempo $t+1$ (item d). 


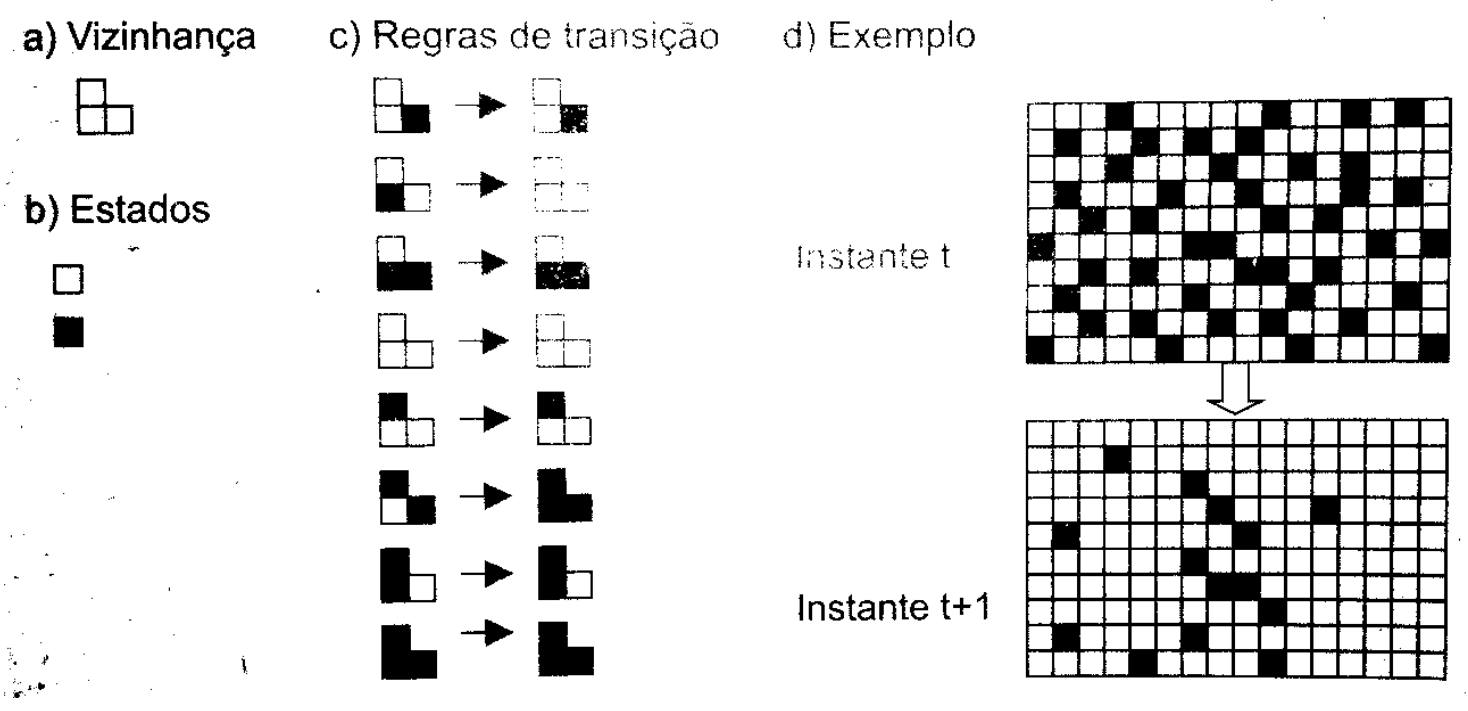

Figura 3.1 - Simulação do Jogo da Vida, indicando a vizinhança, os estados, as regras de transição e a simulação em uma grade aleatória. (CAMARA, 1996)

Segundo Batty et al. (1997), os CA possuem quatro elementos básicos, conforme é descrito a seguir:

- células - referem-se às as unidades espaciais e podem assumir diferentes formatos geométricos, p. ex., quadrado, retangular, hexagonal, e ocupar as dimensões uni, bi ou tridimensional. As células apresentam relações de adjacência entre si;

- estados - possuem um atributo único apresentado em cada célula em um intervalo de tempo específico;

- vizinhança - pode assumir diferentes formas (em cruz, em janelas de $3 \times 3$, etc.), e o estado dos vizinhos condicionará a mudança ou permanência do estado da célula central.

- regras de transição - são os elementos que condicionam a alteração do estado da célula a cada iteração do modelo (iteração esta que representa um passo de tempo).

Para Almeida et al. (2007) os modelos baseados em CA simulam processos de mudança ou crescimento de classes baseados na vizilhança imediata, conforme Figura 3.2 a seguir, não tomando em conta as ações que ocorrem à distância, sendo que todas as mudanças globais representadas são frutos de decisões lógicas locais. 


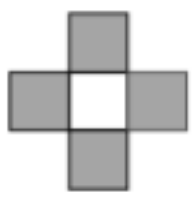

Vizinhança de Von Newmann

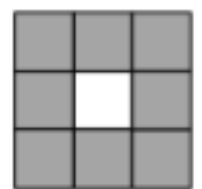

Vizinhança de Moore

Figura 3.2 - Tipos de vizinhança (LIU, 2009)

Em estudo sobre o funcionamento dos CA, Liu (2009) considerou uma cidade hipotética sobre uma grade regular, sendo que cada célula poderia assumir apenas dois estados, urbano ou não urbano, de forma que algumas poucas regras podem alterar a maneira como o crescimento se daria.

Neste experimento, usando a vizinhança de Moore, a pesquisadora estabeleceu inicialmente uma regra simples: Se há três ou mais células no estado urbano, a célula em questão deve passar a este estado e permanecer como não-urbano se o contrário for mantido. A Figura 3.3 a seguir apresenta 0 resultado desta simulação sobre a cidade inicial (t0) por 25 passos de tempo (t25). É possivel verificar que, não tendo nenhuma condição que indus ou retrai a expansão, a mancha final mantêm o caráter arredondado que possuía no início.

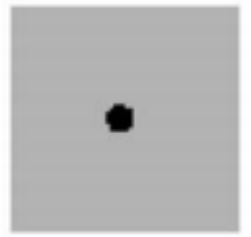

$t=0$

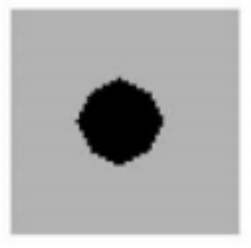

$t=15$

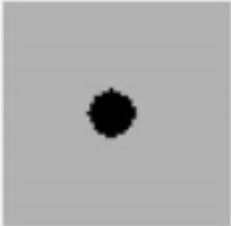

$\mathrm{t}=5$

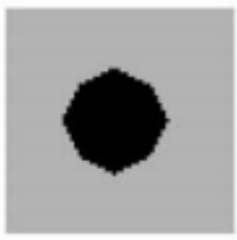

$\mathrm{t}=20$

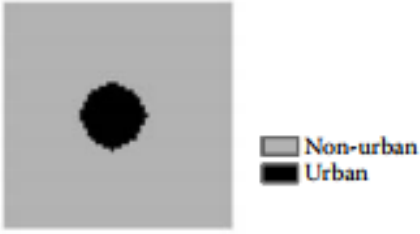

$t=10$

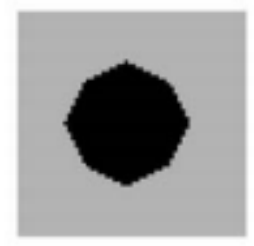

$\mathrm{t}=25$

Figura 3.3 - Desenvolvimento de um núcleo de classe urbana (LIU, 2009).

Com objetivo de verificar a influência do relevo sobre essa cidade hipotética, a autora do estudo carregou como base complementar um mapa hipsométrico e acrescentou uma segunda regra, a qual dizia que se a altitude estiver acima de $300 \mathrm{~m}$, a célula deve permanecer no estado não urbano, ao passo que se houver uma altitude abaixo de $300 \mathrm{~m}$ a transição deverá ocorrer. 
A Figura 3.4, a seguir, apresenta o resultado da aplicação dessa nova regra, para os mesmos 25 passos de iteração.

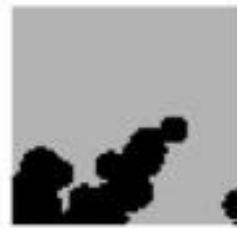

(a) Relief

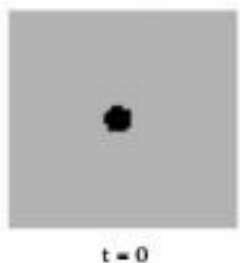

$t=0$

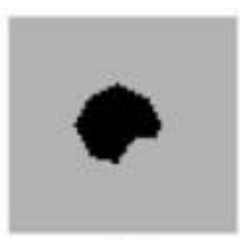

$t=15$

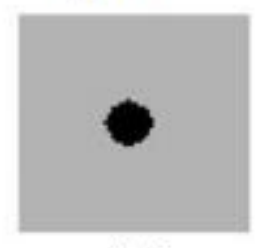

$t=5$

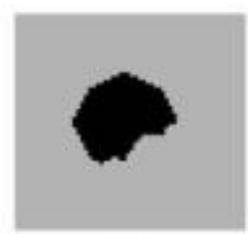

$\mathrm{t}=20$

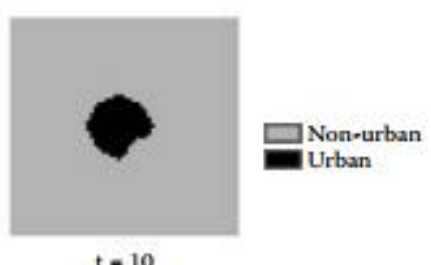

$t=10$

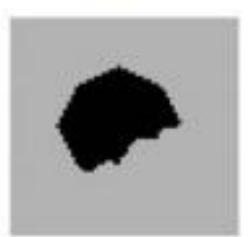

$t=25$

Figura 3.4 - Desenvolvimento de um núcleo de classe urbana, com a inserção da variável do relevo (LIU, 2009).

Para finalizar seu estudo, a autora incluiu também uma estrada para simular o efeito das vias de acesso no crescimento das cidades. Neste caso a via exerce uma influência positiva, e para simular isso a autora inseriu uma terceira regra antes de realizar a ultima simulação. Com isso, se uma ou mais células estiverem em contato com a rede viária, a célula não-urbana passa para o estado urbano. A Figura 3.5 apresenta o resultado deste conjunto de regrar no período de 25 passos. 


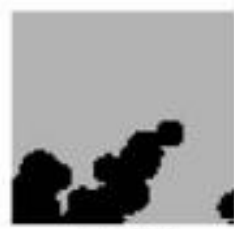

(a) Relief

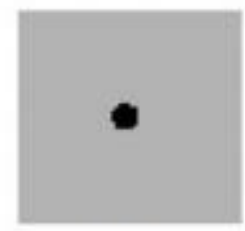

$t=0$

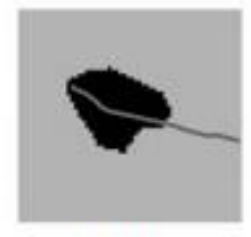

$t=15$

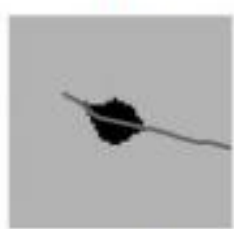

$t=5$

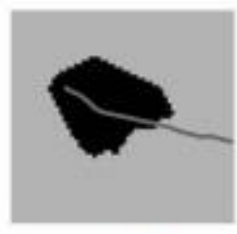

$t=20$

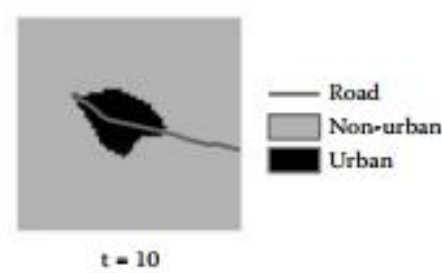

$t=10$

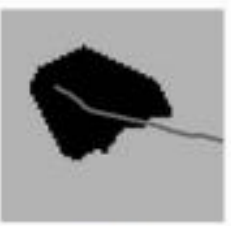

$t=25$

Figura 3.5 - Desenvolvimento de um núcleo de classe urbana, com a inserção da variável do relevo e de uma estrada (LIU, 2009).

Diante dessa característica dos modelos baseados em CA conseguirem representar os sistemas mais complexos a partir de regras especificas a cada caso, e cálculos adaptados à temática urbana, faz com que seja uma excelente ferramenta de apoio à compreensão destes fenômenos.

Segundo Almeida et al. (2007), os anos 1990 experimentaram um significativo melhoramento nos modelos urbanos baseados em autômatos celulares, com a incorporação de váriaveis espaciais, ambientais, sócioeconômicas e políticas diversas, sendo bem sucedidos na articulação entre fatores multiescalares.

Ao longo deste período surgiram algumas variações de modelos quanto ao ajuste dos mecanismos de simulação e dos dados de entrada, de tal forma que é possivel distinguir três abordagem distintas. A primeira se refere aos modelos mais tradicionais, nos quais os parametros são computados com base em equações probabilísticas aplicadas sobre os dados obtidos por observações empiricas. A segunda abordagem trata dos modelos que utilizam equações determinísticas sobre resultados preliminares para obter os parametros de entrada. Por fim, a terceira abordagem utiliza métodos não paramétricos para ajuste de padrão, tais como as redes neurais e os algoritmos genéticos, sendo 
este último um dos campos de pesquisa promissores da área (Almeida et. al.,2007).

A título de exemplificação, Omrani et al. (2012) utilizaram um modelo que se enquadra nesta terceira abordagem, com autômatos celulares integrados a redes neurais para simular mudanças de uso da terra. A vantagem das redes neurais artificiais em relação aos métodos estatísticos reside no fato de que estes últimos tendem a considerar as variáveis independentes e igualmente distribuídas, como os modelos de regressão, por exemplo, ao passo que dados espaciais tendem a apresentar dependência espacial, algo que é tratável por métodos não-paramétricos como as redes neurais. Os pesquisadores utilizaram mapas do projeto Corine de 1990 e 2000 e aplicaram o método à cidade-sede de Luxemburgo na Europa. Como resultado, obtiveram índices superiores aos obtidos por outros pesquisadores na mesma área com um modelo de regressão logística.

Dentro de uma abordagem mais tradicional, o modelo Dinâmica-EGO vem ganhando destaque entre a comunidade cientifica, sendo bastante utilizado no Brasil e em alguns outros países. O próximo sub-item discorrerá sobre 0 emprego deste modelo em estudos sobre as mudanças ocorridas na cobertura do solo ao longo do tempo.

\subsubsection{Dinamica-EGO}

Este modelo tem sido largamente usado para modelar desmatamentos (CHADID et al., 2015; STAN et al., 2015), regenerações florestais (MALEK et al., 2015), alterações no uso do solo urbano (ALMEIDA et al., 2003b; ALMEIDA, 2004; ALMEIDA, et al., 2005; AKIN et al., 2015), dinâmicas da cobertura da terra (SUAREZ; CANDEIAS, 2014), proposição de zoneamento ecológico-econômico, entre outros.

Mas et. al. (2014) realizaram um estudo de comparação entre os modelos IDRISI's CA_MARKOV, CLUE-S/Dyna-CLUE, LCM-Land Change Modeler e Dinamica-EGO. O estudo buscou comparar como cada modelo estima a quantidade de mudanças, como estabelece uma relação entre as variáveis explicativas e os graus de mudanças potenciais, como aloca as mudanças e 
como simula os padrões espaciais. Além disso, também envolveu a simulação de um estudo de caso virtual que permitiu isolar as variáveis de interesse para comparação.

Lima et al. (2013) também empreenderam um estudo para comparar o Dinamica-EGO e o Land Change Modeller, buscando o melhor desempenho na modelagem do desmatamento da amazônia, utilizando mapeamentos dos anos de 1997 e 2000 para a calibração dos modelos. Os resultados apontam que a performance do Dinamica-Ego foi capaz de responder melhor às alterações, se aproximando mais da realidade, sendo considerado por eles como uma plataforma mais versátil.

As conclusões destes dois trabalhos apontam algumas vantagens que 0 Dinamica-Ego apresenta em relação aos demais, principalmente no que tange à possibilidade de avaliar a qualidade de cada variavel na geração dos pesos de evidência, permitindo que o usuário edite a entrada do modelo de modo a criar um conjunto mais coeso. Além disso, em função da quantidade de ferramentas disponiveis, o Dinamica-Ego fornece maior flexibilidade para o usuário desenvolver o modelo.

Estudando a área urbana de Sidney na Australia, Liu (2009) buscou entender como evoluiu, entre 1976 e 1994, a influência da rede de transportes no desenvolvimento e crescimento urbano da cidade, identificando eixos de crescimento e as principais consequências da implantação de importantes rodovias.

O Dinamica EGO, utilizado neste trabalho, foi desenvolvido e distribuído pelo Centro de Sensoriamento Remoto da Universidade Federal de Minas Gerais, encontrando-se em sua terceira versão. Por se um software de licença livre pode ser baixado sem ônus a partir do sítio virtual http://csr.ufmg.br/dinamica.

Suas variáveis de entrada são os mapas da paisagem, iniciando por mapas de uso e cobertura tomados em dois períodos de tempo (T0 e T1), os quais serão a base para o cálculo das matrizes de transição. Além das variáveis estáticas, o Dinamica-EGO pode incorporar variáveis dinâmicas na simulação, 
as quais são recalculadas a cada iteração do modelo, sendo continuamente atualizadas de modo a influenciar o cálculo das probabilidades de transição no passo de tempo seguinte (SOARES-FILHO et al., 2009). Um esquema básico das etapas do processamento no Dinamica-EGO foi realizado por Kawashima (2015) e é apresentada na Figura 3.6, a seguir:

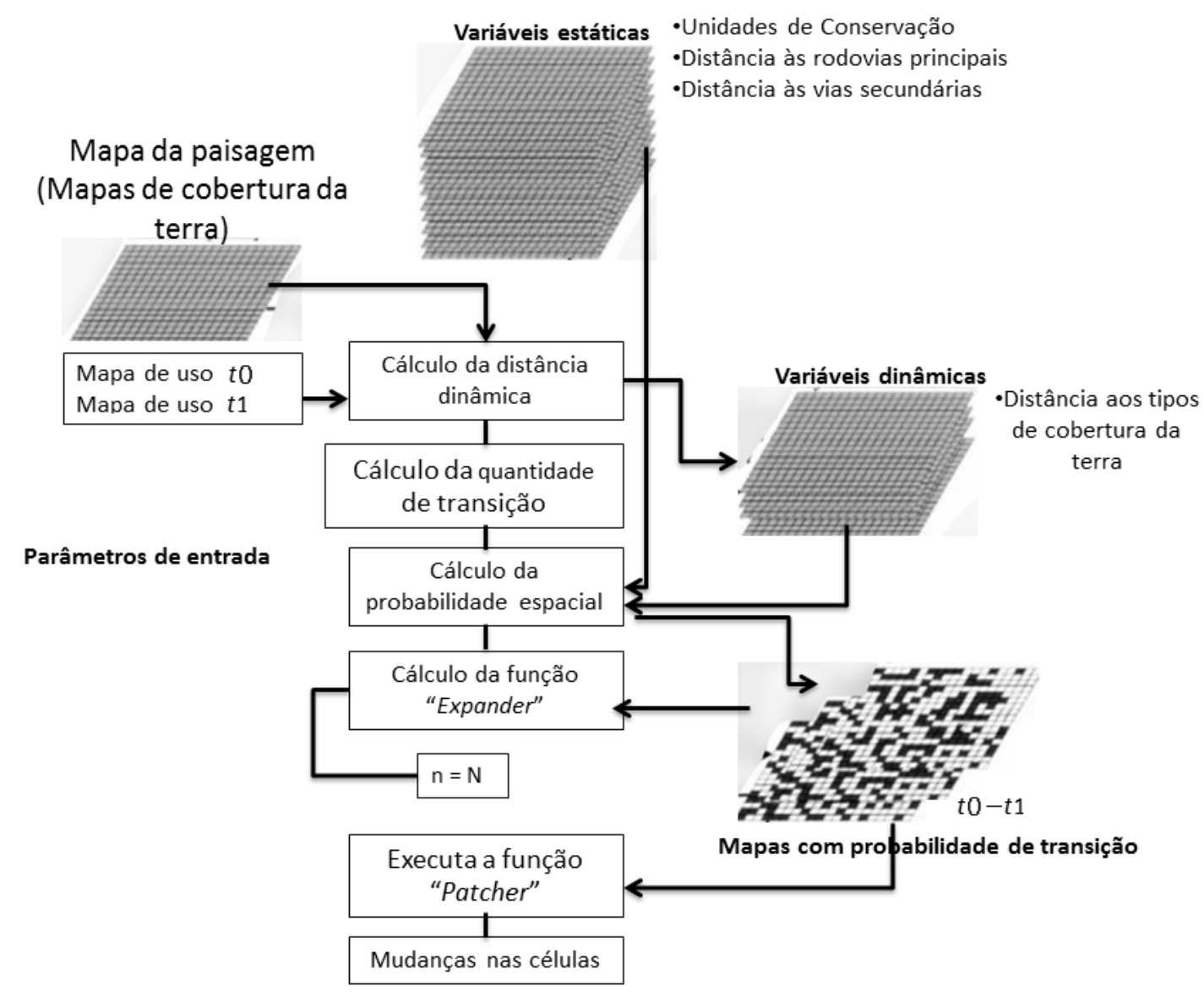

Figura 3.6 - Etapas do processamento do Dinamica-EGO, adaptado de Kawashima (2015)

Este software é a compilação de um conjunto de algoritmos (chamados de functors) que permitem a construção de modelos de simulação baseados em autômatos celulares, cujas etapas são realizadas a partir de functors para parametrização, calibração e validação dos modelos, o que o torna especialmente concebido para a reprodução das alterações das formas da paisagem, o constitui uma importante ferramenta para análise e simulação de paisagens (SOARES-FILHO et al., 2009).

Uma das etapas mais importante é a extração dos pesos de evidência, que é usado para calcular a probabilidade de transição de uma determinada 
classe para outra. O algoritmo implementado no software do Dinâmica-EGO baseia-se no teorema de probabilidade condicional de Bayes, que calcula a possibilidade de um evento ocorrer, dada a ocorrência de outro evento (Soares Filho et. Al. 2009).

Assim, os pesos de evidência são calculados sobre as faixas de distância de uma determinada variável e tem como resultados um mapa de probabilidades para cada transição possível e a influência de cada variável, indicando se a variável atuou positiva ou negativamente na ocorrência de uma dada transição.

A única exigência para utilização deste método é que os pares de variáveis sejam espacialmente independentes. O Dinâmica-EGO realiza a avaliação dessa condição por meio do índice de Cramer (V) e pela Incerteza da Informação Conjunta (JIU).

O índice de Cramer, proposto por Bonham-Carter (1994), é apresentado na Equação 3.1, a seguir:

$$
V=\sqrt{\frac{X^{2}}{T . . M}} \quad \text { Equação } 3.1
$$

Onde, T são os totais marginais da matriz de tabulação cruzada entre os mapas $A$ e $B, X^{2}$ é a estatística qui-quadrado e $M$ o mínimo de (n-1, m-1_em que $\mathrm{n}$ é igual ao número de linhas e $\mathrm{m}$ o número de colunas da matriz de tabulação cruzada entre os mapas das variáveis avaliadas.

Por sua vez, a Incerteza de Informação Conjunta (JIU), que também se baseia em uma matriz de tabulação cruzada. Foi apresentada por BonhamCarter (1994) conforme a equação 3.2, a seguir:

$$
J I U(A, B)=2[H(A)+H(B)-H(A, B) / H(A)+H(B)] \quad \text { Equação } 3.2
$$

Em que $\operatorname{JIU}(A, B)$ pode ser usada como medida de associação entre os mapas A e B.

Os dois índices têm como resultado um índice que varia entre 0 e 1, e indicam a total independência entre o par de variáveis avaliado (à medida que se aproxima de 0) e a total dependência entre eles (à medida que se aproxima 
de 1). Via de regra, os dois índices são visualizados e uma das variáveis deverá ser excluída quando o valor em qualquer um dos índices é maior que 0,5.

Segundo Soares Filho et. Al. (2009), a simulação dos cenários é baseada em dois algoritmos distintos, implementados nos functores expander e patcher. O functor expander realiza a expansão das manchas previamente existentes no mapa de cobertura do solo, de modo que a realização as transições de uma classe i para a classe j baseando-se basicamente nas relações de adjacências das células, ao passo que o functor patcher realiza a formação das de novas manchas, de modo que as transições da classe i para a classe j ocorrem apenas nas vizinhanças de células diferentes do estado j.

Como os dois algoritmos adotam mecanismos estocástico de seleção e alocação das células que farão as alterações, os resultados das simulações serão diferentes mesmo que as variáveis e parâmetros sejam mantidos.

\subsection{Sistemas de Transportes e Mudanças na Cobertura do Solo}

Os padrões de deslocamento em função da cobertura do solo resultam de uma grande gama de fatores, dentre os quais se destacam a necessidade do deslocamento de indivíduos para trabalho e lazer, bem como o transporte de carga por diferentes meios, sejam ferroviárias, rodoviárias, hidroviárias ou aeroviárias.

Atualmente, há na literatura cientifica uma percepção bastante difundida na qual se afirma que os sistemas viários para transporte de pessoas e cargas em conjunto com a cobertura da terra fazem parte de um sistema dinâmico intimamente integrado, cujas interações interferem mutuamente em suas estruturas.

Para Echenique (1975 apud LOPES, 2010) as alterações na acessibilidade a um determinado local, de forma a ampliar ou reduzir a acessibilidade, provoca alterações na cobertura e uso da terra em um determinado local na mesma medida em que alterações na cobertura e uso da terra induzem a realização de novas modificações no sistema viário local ou regional. 
Wegener \& Fürst (2004) consideram que os transportes estabelecem uma relação dialética com as diferentes classes de cobertura e uso da terra. Com isso, os autores afirmam que o tipo de cobertura e uso do solo existente exerce pressão de demanda sobre uma determinada estrutura de transporte. Para atender a essa demanda é preciso equilibrar a oferta por meio de transporte, ampliando a rede viária, adotando novos modos de transporte ou inserindo novas tecnologias nos meios já existentes, ou uma combinação de mais de uma dessas opções. Nestes casos o resultado é a ampliação da oferta.

Segundo estes autores, porém, no momento em que a demanda e a oferta a uma estrutura de transportes atingem 0 equilíbrio, surgem novas oportunidades para alocação de empreendimentos comerciais, industriais e/ou residenciais. Isso se reflete em alterações na cobertura e uso da terra, que tende a sofrer expansão e, com isso, amplia-se a demanda por meios de transporte mais eficientes, tanto de carga como de pessoas, reiniciando um ciclo de retroalimentação continuo, que tende a continuar ocorrendo à medida que será o crescimento das cidades. Os autores chamaram esse processo de ciclo do uso do solo e transportes e sintetizaram o processo na Figura 3.7 a seguir:

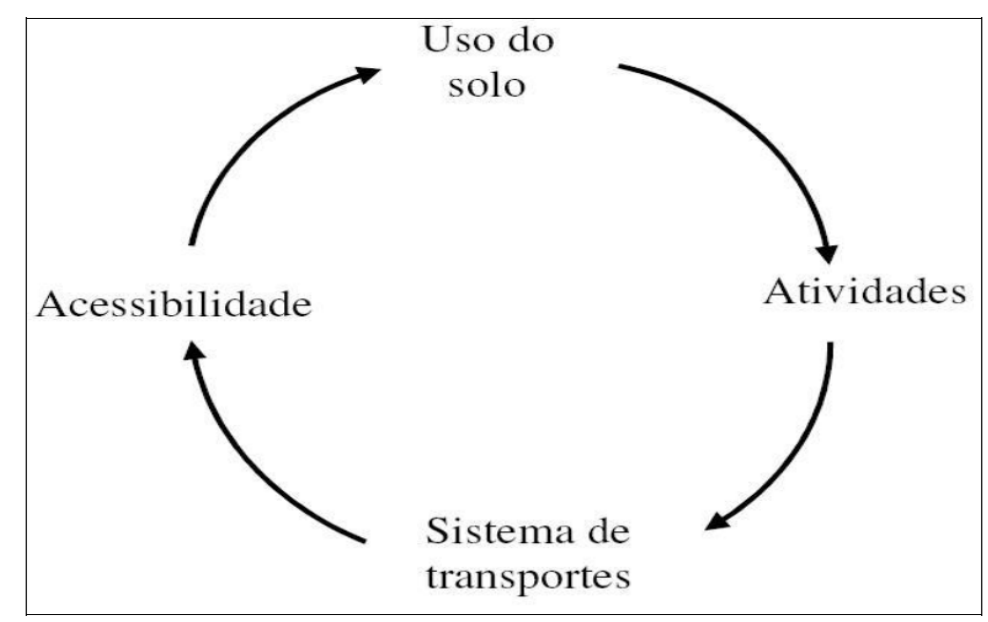

Figura 3.7 - Ciclo do Uso do Solo e Transporte segundo (WEGENER; FÜRST, 2004).

Ainda sobre este ciclo, Wegener \& Fürst (2004) destacaram que as distribuições existentes das classes de uso e cobertura do solo urbano (residencial, industrial, comercial, entre outros) estabelecem uma forte influência/determinação sobre os locais de habitação, trabalhos, compras, entre outros, que serão alocados. Basicamente isso quer dizer que é mais provável 
ocorrer o surgimento de um núcleo residencial ou comercial onde houver a conexão com o sistema viário ou a ampliação de uma dessas áreas já existente, com a alocação de novos empreendimentos nas proximidades. Segundo estes autores o mérito do ciclo do uso do solo e transportes é o fato de incorporar os dois elementos mais fundamentais dos processos urbanos, ou seja, a cobertura do solo e os sistemas de transportes.

Nesta mesma linha de raciocínio, para Villaça (2001) há uma relação íntima entre as vias regionais de transporte e o crescimento físico das cidades. Para ele, o primeiro efeito da implantação de uma via regional é a melhoria da acessibilidade e com isso a valorização dos terrenos, sendo que frequentemente o valor atribuído à terra em função da existência de uma via regional é frequentemente maior que o valor da própria via.

Em virtude dessa possibilidade de converter a terra rural em terrenos urbanos se torna bastante comum a especulação das áreas adjacentes à área urbana. E uma vez que essa conversão tenha ocorrido, a recente área urbana, conectada ao restante da cidade pelos sistemas viários e de transportes, passa a exercer influência na transformação da paisagem.

E completando o cenário, é a distribuição espacial das classes de cobertura e uso do solo em conjunto com a acessibilidade que influenciam nas decisões e comportamentos e atividades dos indivíduos, bem como na alocação de pontos comercial e industrias, o que determina por sua vez as interações que serão realizadas por meio dos deslocamentos físicos.

Em suma, são as necessidades de deslocamento que atuam na distribuição da infraestrutura de transporte e nas decisões de roteamento individual.

As distâncias na cidade são frequentemente medidas em tempo, e variam conforme os pontos de partida e chegada, o horário e sentido de deslocamento, o dia da semana e o modo de transporte utilizado.

Tendo em vista a perspectiva das atividades e a acessibilidade, Pacheco (2001) diz que 
.... população e respectivas atividades distribuem-se no território disputando localizações mais próximas dos recursos e/ou atividades que precisam e/ou desejam, num quadro geográfico cujo adensamento é, portanto, resultado da competição pelos usos do solo urbano, competição essa à qual parece não ser alheia a valorização decorrente das condições de acessibilidade, como causa-efeito do desenvolvimento.

Com esta perspectiva, para Villaça (2001) a acessibilidade torna-se o valor de uso mais importante, sendo considerado em todos os aspectos de compra e venda de lotes, terrenos e imóveis, tanto para fins residenciais como pontos comerciais e industriais.

Com isso, segundo este autor, quando o sistema intraurbano de transportes representa ampliação da oferta de transporte à população, cria a possibilidade de ocupação dos pontos mais distantes da cidade, garantindo a fixação de um excedente de população. Quando o crescimento das cidades ocorre em ritmo acelerado, como é o exemplo de grande parte dos municípios na RMSP.

Além disso, os meios de transporte agem de modo a polarizar as atividades urbanas organizadas territorialmente. A ligação das populações e atividades entre os pontos intraurbanos e interurbanos é articulada por meio de terminais (estações, portos e aeroportos) e vias de acesso, as quais criam a tendência para que as classes de uso urbano se organizem no entorno dos terminais e das vias (VILLAÇA, 2001).

Todo este conjunto de elementos, que incluem a influência das grandes vias de transporte regionais, os terminais de acesso a estes sistemas e os sistemas de transporte intraurbanos podem ser observados no desenvolvimento da paisagem paulista, como será visto a seguir.

Para o caso do estado de São Paulo, Monbeig (1998) descreveu uma forte correlação entre a disposição e desenvolvimento das cidades em função das vias de transportes na direção oeste, inicialmente seguindo o traçado dos principais rios e, posteriormente, a linha férrea, particularmente nos pontos de entroncamentos ao redor das estações ferroviárias, sendo que esse processo passa a ser mais intenso no início do século XX. 
O autor destaca que após a abertura de uma dada estação de trem no oeste paulista, aquilo que era apenas um povoado disperso tornou-se rapidamente uma cidade em franco desenvolvimento, sendo uma condição recorrente no cenário paulista.

Tendo nascido e se formado na França, país de cidades cujo crescimento ocorre em ritmo muito menos acelerado, Monbeig conseguiu elucidar uma característica das cidades paulista a partir de uma perspectiva pessoal. Ele destacou fortemente em seu trabalho a velocidade com que o surgimento e crescimento das cidades ocorreram no estado. Nas palavras de Monbeig (1998):

"Tudo se passa como se este país (o Brasil) conhecesse em setenta e cinco anos, um século no máximo, o que se levou milênios para fazer na Europa".

De acordo com Santos (1993), a urbanização brasileira teve como característica a rápida transformação do espaço e foi pautada pela interação com as redes logísticas, notadamente os entroncamentos e as estações ferroviárias, as margens rodoviárias e os terminais hidro e aeroportuários.

A relação entre as características da cobertura e uso da terra e os transportes ou a maneira como um influencia o outro, tem sido tema de estudos de inúmeros pesquisadores, com abordagens diferentes, seja do ponto de vista da evolução dos tipos de uso e cobertura do solo tendo o sistema de transporte como variável de entrada (ALMEIDA, 2004; KAWASHIMA, 2015), do ponto de visto da modelagem dos sistemas de transportes (LOPES, 2010) ou o caso específico da interação entre os dois temas (ALJOUFIE et al., 2013).

Um estudo realizado pelo Departamento de Transportes de Londres (TASM, 2014) destacou três características dessa relação: A) as interações entre as atividades e os tipos de uso geram demanda por transporte; B) a quantidade dessas interações influencia diretamente a disponibilidade de transporte; C) com isso, conhecer estas conexões são importantes para a definição das políticas de transporte.

Há atualmente uma tendência em propor diferentes métodos para o estudo da relação de influência entre transportes e cobertura do solo. Dentre 
estes métodos, é possível incluir a modelagem de cenários virtuais, que buscam recriar os processos dinâmicos da realidade no ambiente digital.

A principal justificativa desta linha de pesquisa é que um modelo desenvolvido para uma determinada localidade pode auxiliar na identificação dos eixos de transições, bem como a identificação dos componentes espaciais que afetam ou afetaram as transições na cobertura e uso do solo, tais como a implantação de uma nova via de tráfego ou um aeroporto, por exemplo.

Um dos exemplos é o de Aljoufie et al. (2013), que estudaram as transformações urbanas ocorridas em Jeddah, Arábia Saudita. A cidade está localizada na planície entre as montanhas Hijaz e o Mar Vermelho, de tal forma que o espalhamento horizontal da cidade se deu no sentido noroeste-sudeste, sendo fortemente influenciada pelos condicionantes deste relevo.

Para estudar essas transformações urbanas, estes autores aplicaram o Metronamica - LUTI, um modelo integrado que é baseado em autômatos celulares e relacionado aos transportes, consistindo de quatro módulos.

Os resultados obtidos por Aljoufie et al. (2013) corroboraram que a acessibilidade é um forte indutor das alterações na cobertura e uso da terra, e este fato foi corretamente simulado no experimento. Segundo eles, os modelos integrados dão uma resposta melhor que modelos isolados para a análise das transformações na cobertura e uso da terra, porém têm uma calibração muito mais complexa, o que pode inviabilizar seu uso em alguns casos. O uso de autômatos celulares permitiu a eles trabalhar com uma paisagem diversa, com 12 diferentes classes de uso e cobertura e regras complexas de transição.

Outra aplicação importante para os modelos baseados em autômatos celulares é a inserção de uma variável não existente com o objetivo de avaliar seus impactos em um determinado ambiente. O trabalho de Basse (2013) é um típico exemplo deste estudo.

A autora estudou os impactos da implantação ou não de um trem de alta velocidade entre as cidades de Cane, Nice, Mônaco e Ventimiglia, utilizando o modelo Moland, que também se baseia em autômatos celulares e é alimentado por dados temporais de uso da terra. 
Assim, após a validação do modelo, a autora criou três cenários com horizonte no ano de 2040: um sem a linha de trem, e os outros dois considerando as estações no centro das cidades e na área periurbana.

Para Basse (2013) a maior dificuldade de trabalhar com este modelo foi reunir os dados em sua complexidade, mas apresentou bons resultados sobre a relação entre uso da terra e transportes. De fato, quando instaladas fora da área urbana, as estações foram responsáveis por provocar um espraiamento generalizado de área urbana sobre outros tipos de uso, ao passo que quando localizadas no centro, a estação provocou uma intensificação das atividades no entorno delas. Sem a construção da linha de trem de alta velocidade, a modelagem indicou um crescimento no entorno das áreas já consolidadas, seguindo as conformações do relevo.

Lasalvia (2006) analisou, entre outros, como os meios de transporte influenciaram na trajetória do município de Guarulhos, dada sua estreita relação com o município de São Paulo. A autora destacou três períodos cujo desenvolvimento foi marcado pela existência do acesso ao município de Guarulhos: a estrada Nova Conceição a partir de 1600 e a estrada geral por volta de 1730; a inauguração da linha ferroviária no ano de 1915; e a rodovia Presidente Dutra, inaugurada em 1951, além das conexões por vias secundárias de menor porte. A mesma autora destaca a forte influência relacionada ao aeroporto, que embora não seja um meio de transporte que polarize o entorno por conta do acesso às vias aéreas, o faz pela quantidade elevada de empregos diretos e indiretos que ele é capaz de gerar.

É importante mencionar que, apesar de não trabalhar com modelos matemáticos, o trabalho realizado por Lasalvia (2006) é de grande interesse para esta pesquisa por analisar a história do município de Guarulhos e suas relações com o Aeroporto Internacional de Guarulhos.

É preciso distinguir a influência dos aeroportos no desenvolvimento das manchas urbanas em função das peculiaridades que a ele são imputadas. Para eles, há duas características que condicionam sua relação com a paisagem do entorno. 
A primeira delas é o fato de que terminais aeroportuários possuem limitações quanto à verticalização do entorno, o que reduz o tamanho dos prédios que se permite construir ou impede completamente a construção deles. Além disso, também afetam na disposição das áreas residenciais e industriais conforme o nível de ruído das aeronaves. Essas condições, no caso do Brasil, se refletem na criação de zonas especiais de ocupação nos planos diretores.

Em segundo lugar, está o fato de que os grandes aeroportos são estruturas complexas que demandam um grande efetivo de trabalhadores fixos, além de serviços terceirizados. Acaba gerando um polo econômico para o desenvolvimento de empreendimento de atividades correlatas, tais como shoppings, hotéis, locadoras de veículos, restaurantes, entre outros exemplos, cujas atividades são voltadas para 0 atendimento e entretenimento dos passageiros.

Desta forma, os empregos diretos e indiretos ligados à atividade aeroportuária são fatores cruciais para a geração de um polo de desenvolvimento econômico (SILVA, 1991).

Nesta feita, apesar dos terminais aeroportuários não exercerem uma influência tal qual os terminais ferroviários e, pelo contrário, estabelecer em leis municipais os critérios de ocupação de seu entorno, acaba exercendo influência por meio da quantidade de empregos que gera, pressionando os órgãos responsáveis pelas vias de acesso intraurbano para que sejam realizadas as modificações necessárias para o atendimento da demanda crescente. 


\section{4 Área de Estudo}

\subsection{Localização}

O município de Guarulhos situa-se entre as coordenadas $23,27^{\circ}$ e $23,5^{\circ}$ de latitude sul, e 46,35ㅇ e 46,57ํ de longitude oeste. Está localizado no setor leste do estado de São Paulo, conforme ilustra a Figura 4.1. O Trópico de Capricórnio atravessa o município ao sul do aeroporto.

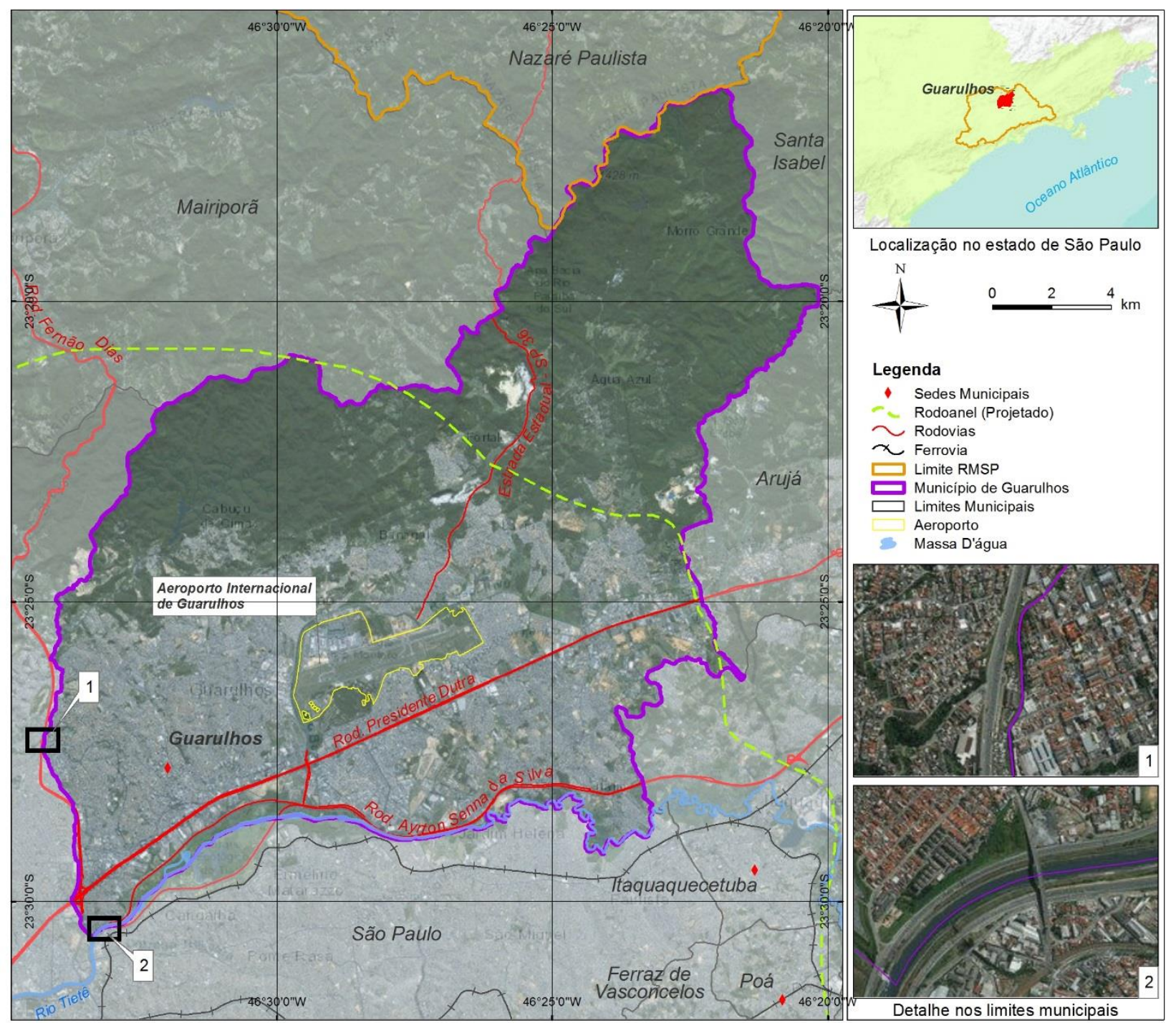

Figura 4.1 - Localização e principais vias do município de Guarulhos. Elaboração própria com base nos dados do Webgeo-Guarulhos.

O município ocupa o setor nordeste da Região Metropolitana de São Paulo - RMSP, a $25 \mathrm{~km}$ do centro do município de São Paulo, e tal como os demais municípios, está completamente inserido na Sub-Bacia do Alto Tietê, sendo limitado ao norte pelos divisores de água das Serras da Pirucaia e Itaberaba e, ao sul, pelo Rio Tietê. 
Como pode ser visualizado na Figura 4.1, os principais acessos ao município são as rodovias Presidente Dutra (BR-116) e Ayrton Senna (SP-070), que possuem orientação SO-NE, irradiadas a partir de São Paulo e a rodovia Fernão Dias (BR-381), com orientação N-S, na direção de Minas Gerais. O Rodoanel Mario Covas (SP-021) se estende até a rodovia Regis Bittencourt (BR116) e se configura como a principal conexão. Também merece nota a estrada Juvenal Ponciano de Camargo (SP-036) que tem caráter secundário, e fornece acesso para os municípios localizados além da Serra da Mantiqueira, conectando Guarulhos a Nazaré Paulista e à rodovia Dom Pedro I (SP-065).

Além destes acessos rodoviários, existe uma forte permeabilidade dos limites conurbados de Guarulhos com os municípios vizinhos, como pode ser observado nos detalhes 1 e 2 da Figura 4.1, onde são apresentadas algumas pontes que conectam os dois municípios cruzando a várzea do rio Tietê ou as grandes vias, no sentido sul e oeste respectivamente. Além disso, também são importantes os limites ao sudeste com Itaquaquecetuba, e a oeste com Arujá. Na direção norte, Guarulhos limita-se com Mairiporã, Nazaré Paulista e Santa Isabel, porém sem a mesma permeabilidade, dada a existência da Serra da Mantiqueira.

Com isso, do ponto de vista do deslocamento de carga no estado de São Paulo (e pode-se dizer, da região Sudeste), o município pode ser visto como um importante nó na malha logística em função da disponibilidade de acesso a essas grandes rodovias em conjunto com a existência de grandes áreas para alocar galpões e indústrias, conforme será visto mais adiante.

Guarulhos tem um total de $318 \mathrm{~km}^{2}$ e abriga uma população de 1,3 milhão de pessoas, as quais vivem exclusivamente em áreas de categoria urbana, segundo o censo de 2010 (IBGE, 2011). Administrativamente, o município tem dois distritos e 47 bairros, apresentados na Figura 4.2. 


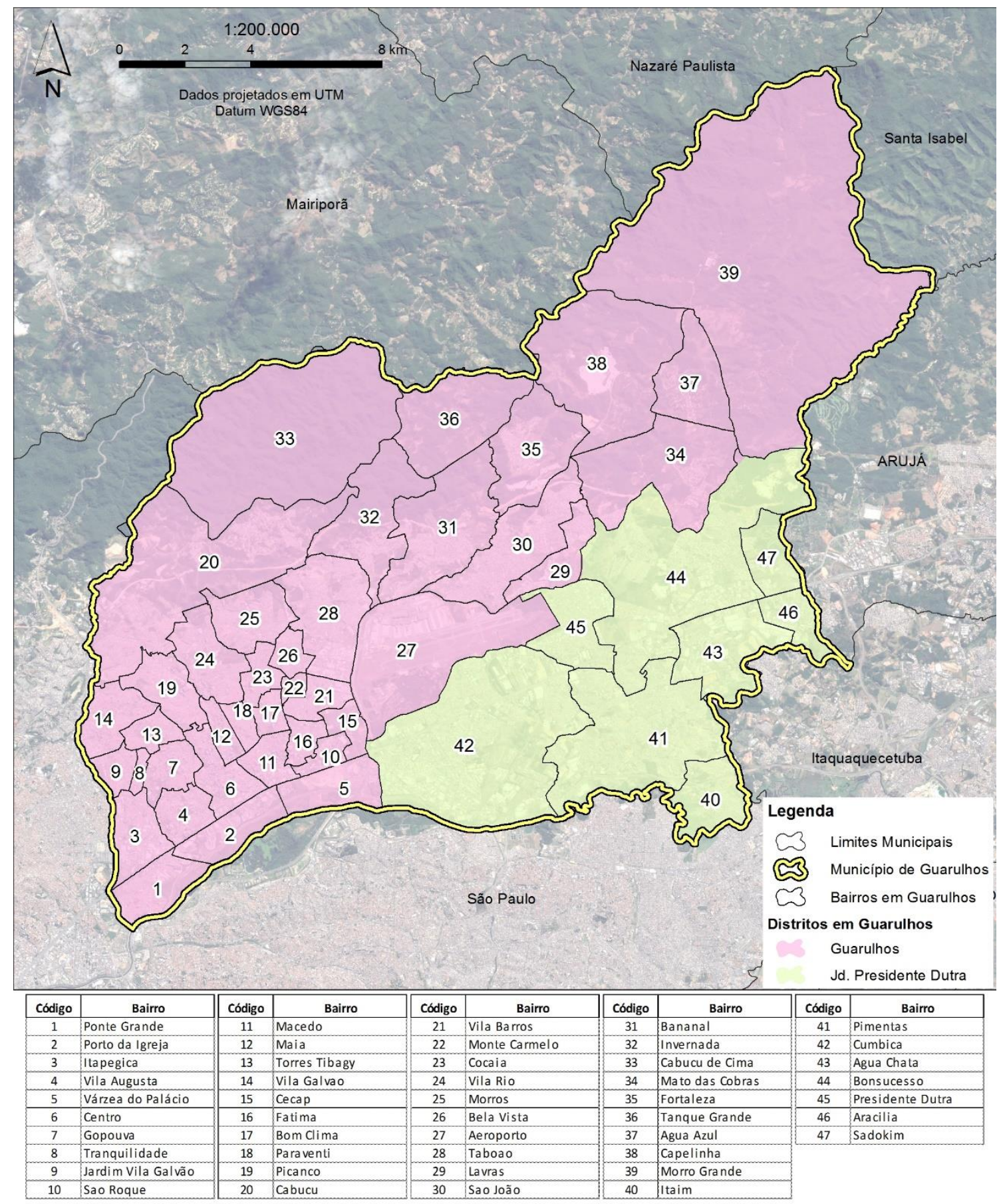

Figura 4.2 - Distritos e bairros no município de Guarulhos. Elaboração própria com base nos dados do Webgeo-Guarulhos.

No contexto da RMSP, Guarulhos se destaca como o segundo município mais importante, tanto no que se refere à população como ao PIB e oferta de empregos em geral. O presente capítulo busca agregar e consolidar as informações ambientais e socioeconômicas referentes ao município, com o objetivo de auxiliar no processo da modelagem. 


\subsection{Geografia Física de Guarulhos}

Do ponto de vista geológico, a área de estudo assenta-se sobre a Província Mantiqueira que, de acordo com Almeida (1977), possui direção NE-SW, com paralelismo ao litoral brasileiro, caracterizando-a pelos "maciços medianos" e faixas de dobramento ou faixas móveis, com zonas de falhas com orientação mais ou menos paralela a esta direção geral.

No caso de Guarulhos, chama a atenção o território seccionado de lado a lado pela falha do rio Japari, com orientação NE-SW, compartimentando o município em duas áreas de clara diferenciação, doravante chamadas de setor norte e setor sul, como pode ser observado no Quadro A da Figura 4.3.

Segundo Oliveira et al. (2009), no setor norte localizam-se as rochas do embasamento cristalino denominado de Domínio São Roque, com presença de rochas do tipo ígneas e metamórficas, destacando-se os granitoides, migmatitos, xistos e quartzitos.

O setor norte possui altitudes médias entre $850 \mathrm{~m}$ e $1200 \mathrm{~m}$, com ponto culminante no Pico do Gil (1.438 m), na Serra de Itaberaba. Aí, o relevo é mais movimentado, com existência de vales assimétricos e rampas com inclinações superiores a $45^{\circ}$, o que ocasionalmente pode acarretar movimentos de massa com acúmulo de depósitos coluvionares. O mapa geomoforlógico elaborado por Ross (2006) e apresentado no Quadro A da Figura 4.3 denomina esta área de Planalto Atlântico. Oliveira et al. (2009), em trabalho mais detalhado compartimentaram o setor em montanhas, morros, morrotes e escarpas.

Por outro lado, ao sul da falha do rio Japari, estão as rochas do embasamento cristalino do Domínio Embu, também composto por rochas de origem ígneas e magmáticas. Contudo, tais rochas cristalinas afloram apenas localmente a sudeste do município, onde é possível constatar uma unidade paragnáissica. Quase que a totalidade do setor sul está coberta por pacotes sedimentares oriundos dos períodos Terciário e Quaternário. 
A origem destes pacotes sedimentares terciários, segundo Oliveira et al. (2009), está diretamente relacionada aos sistemas de leques e planícies aluviais com sedimentos oriundos das áreas à montante da falha do rio Japari. A altitude máxima dos sedimentos é de $840 \mathrm{~m}$, que atinge o nível de base da superfície São Paulo, a qual acumulou sedimentos até o limite superior do Terciário, quando então se iniciou um novo ciclo erosivo, responsável pela formação dos sistemas de colinas nestes pacotes.

Além destes, ainda é preciso destacar as áreas cobertas com sedimentos quaternários, constituídos pelos depósitos aluvionares e coluvionares, como resultado dos processos atuais de erosão e deposição de sedimentos.

Desta feita, o setor sul apresenta relevo menos movimentado, com declividades mais suaves que as encontradas no setor norte, variando entre $0^{\circ}$ e $10^{\circ}$, interrompidas apenas localmente pela existência de colinas mais inclinadas. Segundo Ross (2006), aí se localiza o planalto de São Paulo e as planícies fluviais do Tietê. Neste trecho as altitudes variam entre $670 \mathrm{~m}$ e $850 \mathrm{~m}$.

O Quadro B da Figura 4.3 apresenta as altimetrias no município de Guarulhos, ultrapassando os 1.400 metros de altitude nas serras de Piracaia e Itaberaba, até altitudes menores que 700 metros, nas áreas de várzea do Tietê (ao sul) e do Paraíba do Sul (a leste). O perfil longitudinal denota a existência de dois patamares principais, um entre 850 e 1.400 metros de altitude e outro abaixo dos 800 metros.

A posição do município nas imediações do Trópico de Capricórnio caracteriza-o como uma área de transição entre dois importantes sistemas climáticos do Brasil. De um lado, o sistema controlado especialmente pelas massas de ar frio oriundas do círculo polar, e de outro, pelas massas de ar provenientes da Zona de Convergência Intertropical (NIMER, 1989). Além disso, a área também recebe umidade do oceano, empurrada pelos ventos alísios, mesmo ele deixando boa parte de sua umidade nas encostas da Serra do Mar.

Segundo Oliveira et al. (2009), no âmbito local, a topografia de Guarulhos acarreta temperaturas sensivelmente mais frias que as encontradas nos municípios vizinhos, e este aspecto é o resultado direto das elevadas altitudes 
da Serra da Mantiqueira ao norte, como pode ser verificado no Quadro C da Figura 4.3, em que se verifica que as temperaturas tendem a diminuir na direção nordeste e crescer à medida que se aproxima das áreas mais centrais, nas porções baixas do município.

De acordo com Oliveira et al. (2009), os solos em Guarulhos são constituídos predominantemente de associações de Latossolos Amarelos e VermelhoAmarelos no setor ao norte da falha do rio Jaguari e, ao sul, de associações de Argissolos Vermelho-Amarelos e Gleissolos. Outras classes, como os Plintossolos e Neossolo, têm ocorrência mais restrita na paisagem.

Na mesma figura, é possível verificar a disposição das isoietas, que indicam a influência das serras na distribuição das chuvas, na medida em que as maiores precipitações ocorrem na base e rampa da serra, diminuindo significativamente nos setores mais elevados.

Em Guarulhos, a precipitação média anual fica em torno de $1.400 \mathrm{~mm}$, podendo haver variações para mais ou para menos em função de fenômenos esporádicos, como o el Niño, por exemplo. Como em toda a região sudeste, a concentração de chuvas ocorre nos meses entre dezembro e março, quando ocorre quase $60 \%$ do total anual de precipitação, ao passo que entre junho e agosto os meses são mais secos, com precipitações mensais em torno de 40 $\mathrm{mm}$.

A temperatura média no município varia entre $15,1^{\circ} \mathrm{C}$ em julho e $26,2^{\circ} \mathrm{C}$ em janeiro, podendo alcançar valores superiores a $30^{\circ} \mathrm{C}$ em determinados momentos do dia no verão. Os meses mais frios são junho, julho e agosto, quando a temperatura média fica abaixo de $16^{\circ}$, podendo chegar a $10^{\circ} \mathrm{C}$, e os meses mais quentes são dezembro, janeiro e fevereiro. Vale destacar que no interior das áreas urbanas, em função da associação entre concreto, asfalto, ausência de vegetação e obstáculos à circulação do vento, a temperatura pode variar em diversos graus em relação ao esperado, para mais ou para menos. 


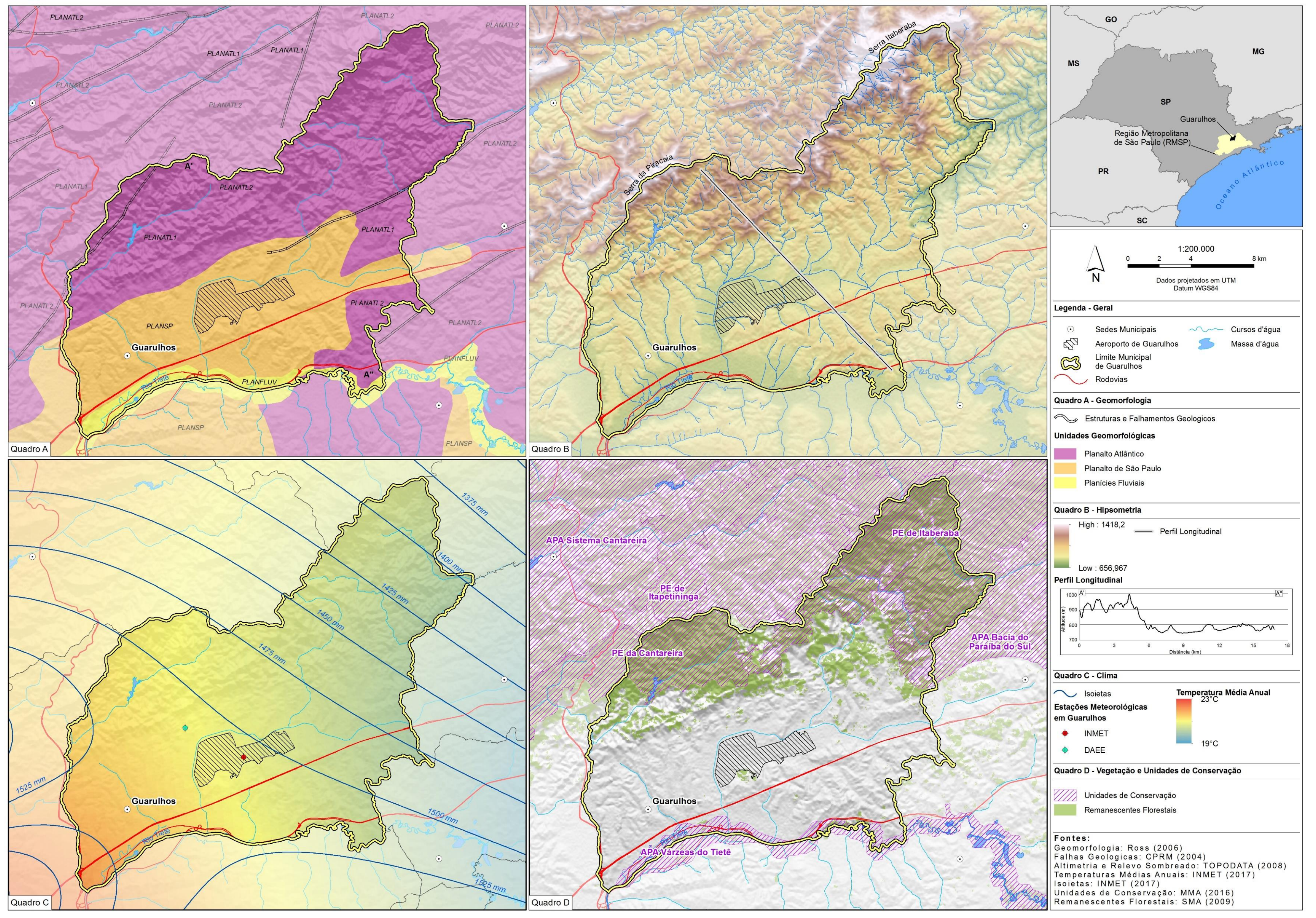

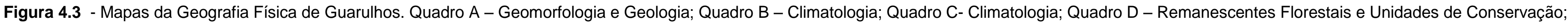


A vegetação original de Guarulhos era composta pela Mata Atlântica em diversos tipos de associação, tendo sido largamente suprimida ao longo dos primeiros séculos da colonização como forma de ampliar o acesso às lavras de ouro no século XVI, e para comportar rebanhos de gado e cultivo de café no século seguinte. Boa parte da mata hoje existente é secundária, em crescimento desde a segunda metade do século XIX, quando se iniciou a recuperação da mata como forma de manter o suprimento de água à capital. Vale destacar que o nome Cantareira tem origem nos cântaros, peças de cerâmica utilizadas para transportar e armazenar água no período pré-moderno.

O Quadro D da Figura 4.3 apresenta a distribuição dos remanescentes florestais no município de Guarulhos, localizados principalmente nas vertentes mais inclinadas em todo o setor norte. Há um mosaico de Unidades de Conservação, cujos limites estão sobrepostos e cujas funções se complementam, caso das Áreas de Proteção Ambiental do Sistema Cantareira e Bacia do Paraíba do Sul que são limítrofes ou sobrepostas aos Parques Estaduais de Itaberaba, de Itapetininga e da Cantareira.

\subsection{Aspectos Históricos e Geografia Humana de Guarulhos}

No que se refere à ocupação do município de Guarulhos, tal como se conhece hoje, Lasalvia (2006) identificou três fases distintas. Segundo ela, a primeira fase ocorre no contexto de formação do Pátio do Colégio, hoje no centro de São Paulo. Para assegurar a existência deste núcleo habitacional, os jesuítas criaram uma série de aldeamentos que formavam um grande arco ao redor deste núcleo fundamental, cujo objetivo era fornecer proteção contra os ataques de indígenas e salteadores. É neste contexto que são criados os núcleos fundamentais de Guarulhos, São Miguel, Itaquaquecetuba, Pinheiros, Itapecerica, Embu, Carapicuíba e Barueri.

No decorrer de um século, o aldeamento de Guarulhos obteve destaque em termos de crescimento, passando de aldeamento a povoado em 1675 e logo depois a paróquia. Segundo Romão e Noronha (apud Lasalvia, 2006), o motivo para esse acelerado crescimento foi a descoberta de ouro nas proximidades do aldeamento na década de 1590, provocando um afluxo constante de pessoas ao 
local, formando também a toponímia que define o local até hoje em dia, como o bairro de Lavras, por exemplo.

Não obstante, as lavras de ouros duraram pouco e no fim do século XVII estavam totalmente esgotadas, sendo substituídas por atividades agrícolas e comerciais sem grande expressão. Porém, essa fase de crescimento acelerado foi fundamental para o estabelecimento de uma rede de estradas que criou a comunicação entre o planalto paulista, o interior, o litoral e, posteriormente, até ao Rio de Janeiro por meio da construção da estrada Geral por volta de 1730, cujo traçado é o da atual estrada de Bom Sucesso.

É preciso mencionar que a conexão com São Paulo era realizada por meio da estrada de Nossa Senhora da Conceição de Guarulhos, que ligava o aldeamento em questão com o aldeamento da Penha, cujo acesso era realizado por meio da Ponte Grande que atravessava o rio Tietê. Este ponto está localizado no setor sudoeste do município e constitui, segundo Lasalvia (2006), o primeiro vetor de crescimento urbano de Guarulhos, o que seria alterado apenas no ano de $1915 \mathrm{com}$ a inauguração da ferrovia, fato que marca o início do segundo ciclo de desenvolvimento do município. Nesse ano são inauguradas as estações Vila Galvão e Vila Augusta, sendo que nos anos seguintes são inauguradas as estações de Copoúva (1922), Torres do Tibagi (1931) e estação Cumbica (1945) que atendia a base aérea da aeronáutica, também inaugurada nesse ano.

De acordo com Langenbuch (1971) a linha ferroviária que chegou a Guarulhos foi a extensão do ramal ferroviário do Sistema Cantareira que buscava alcançar o bairro de Guapira onde se encontrava um hospital com asilo para inválidos e leprosos. O autor destaca que a inauguração da ferrovia é contemporânea ao período de industrialização de São Paulo e por isso, embora tenha sido criada por motivos hospitalares, foi também responsável pelo transporte de passageiros e cargas, o que favoreceu o processo de suburbanização, com expansão de moradias populares e indústrias de pequena ordem. Ranali (1944 apud Lasalvia 2006) destaca a existência de 61 unidades fabris em Guarulhos no ano de 1944, incluindo-se ai estabelecimentos do ramo têxtil, cerâmico, de couro, vinícola e metalúrgico, inclusive com a presença da 
Fábrica Dental Suprema, que naquele ano declarou ter exportado cadeiras de dentistas.

As estações foram fundamentais para a consolidação urbana do município e pela expansão de uma rede de serviços análogos à existência dos fluxos pendulares de pessoas. No entanto tais elementos foram limitados pelo fato de a ferrovia estar localizada nos terrenos mais baixos da várzea do rio Tietê, ao passo que o centro histórico da cidade se localizava em setores mais elevados. $O$ trajeto entre um e outro era vencido por meio de charretes, animais e a pé, mas à medida que o fluxo de pessoas passou a aumentar significativamente, sobretudo a partir da $4^{\mathrm{a}}$ década do século $\mathrm{XX}$, a oferta começou a ficar limitada.

Com o aparecimento dos veículos automotores no cenário brasileiro em comunhão com a versatilidade que eles fornecem, as rodovias começaram a ser construídas em detrimento das vias férreas, sendo a inauguração da Rodovia Presidente Dutra (1951) o marco para o início do terceiro ciclo de desenvolvimento do município de Guarulhos.

É importante mencionar que a construção de grandes estradas se inicia a partir de 1920 com o então presidente Washington Luiz, que dizia que "governar é abrir estradas". Com isso são abertas as primeiras grandes estradas para Minas Gerais, Mato Grosso, Rio de Janeiro que, a despeito de importantes limitações técnicas, como a total ausência de pavimentação em longos trechos das vias, passam a exercer a função de indução do crescimento $e$ desenvolvimento urbano. $O$ processo se intensifica nas décadas seguintes. $A$ Figura 4.4 apresenta a Rodovia presidente Dutra na década de 1960, com duas faixas em cada sentido. 


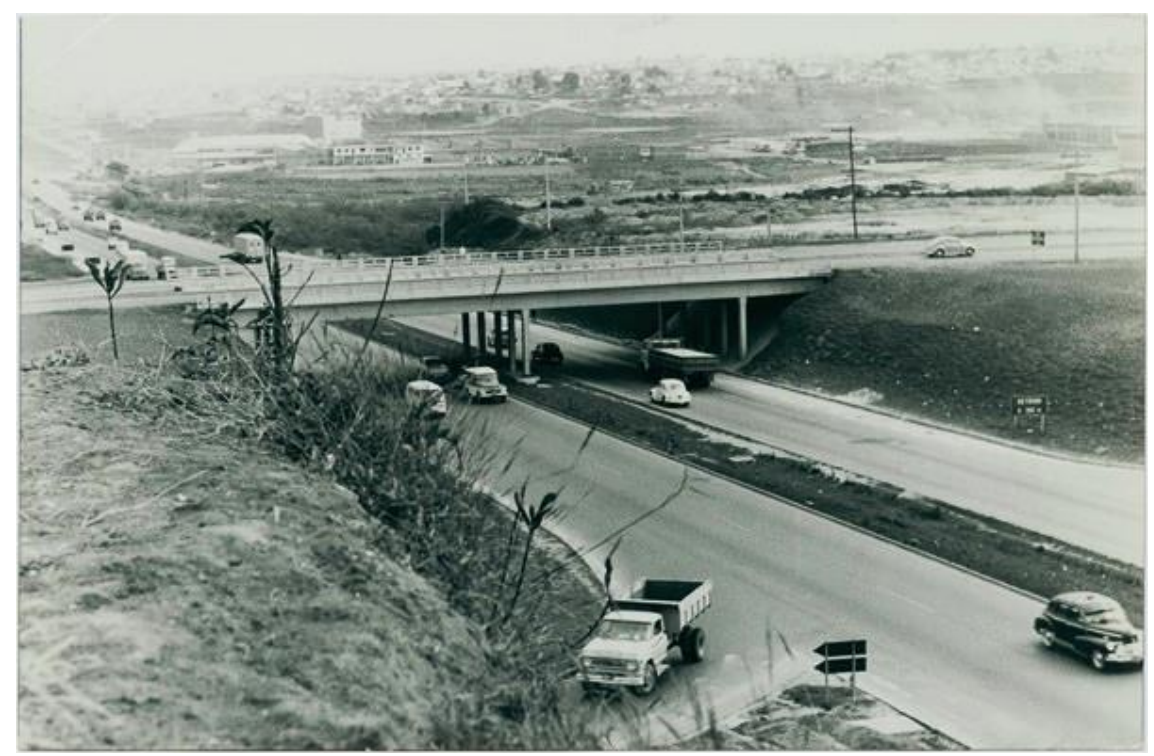

Figura 4.4 - Rodovia Presidente Dutra por volta de 1960. IBGE, 2017

Concomitante a isso, o município de São Paulo passa a se industrializar cada vez mais e a população é constantemente atraída para dentro dos seus limites e suas cidades satélites. É surpreendente o crescimento populacional na RMSP entre 1950 e 1970, que passa de 2.696.031 de pessoas para 8.172.542 de pessoas, um pouco mais de 300\% em duas décadas (MEYER et. al., 2004).

Grande parte dessa população ocupa a cidade de São Paulo, que tem como resultado a elevação do preço das terras em conjunto com a proliferação de problemas ligados à mobilidade interna, o que resulta na desindustrialização do município. As indústrias buscam então municípios vizinhos, com preços de terra mais acessíveis para implantação de grandes galpões e facilidade de acesso às rodovias para escoamento da produção.

A inauguração da Rodovia Presidente Dutra em 1951 e sua posterior duplicação no ano de 1967, resultam na atração de grandes indústrias para o município de Guarulhos a partir da década de 1970, cuja ocupação se deu essencialmente às margens da rodovia, constituindo um importante eixo industrial para atender às demandas da metrópole. Entre os exemplos de indústrias que passaram a ocupar tal eixo estão a Phillips, Ollivetti, Asea elétrica, Pfizer, Toddy, Borton, entre outras.

É nesse momento que o município de Guarulhos passa a ter uma importante alteração na formação da sua paisagem urbana. Segundo Lasalvia (2006), o crescimento urbano que até então estava concentrado no setor 
sudoeste do município, passa a ocorrer de maneira mais dispersa e desordenada. É neste momento que surgem os loteamentos próximos à rodovia e às indústrias que naquele momento passaram a exercer uma força de atração de mão de obra. O município deixa de ser caracterizado apenas como uma cidade dormitório para polarizar a atração de população.

É importante mencionar que a ocupação desses setores mais afastados a partir da década de 1980 foi possível graças à popularização do carro como meio de transporte individual, à expansão das vias de acesso ocorridas na década anterior e à ampliação das redes de transportes coletivos, tanto em termos de linhas de ônibus, como das estações de metrô nas zonas Norte e Leste da cidade de São Paulo. A Figura 4.5 a seguir destaca os movimentos populacionais em função dos três vetores de crescimento. 


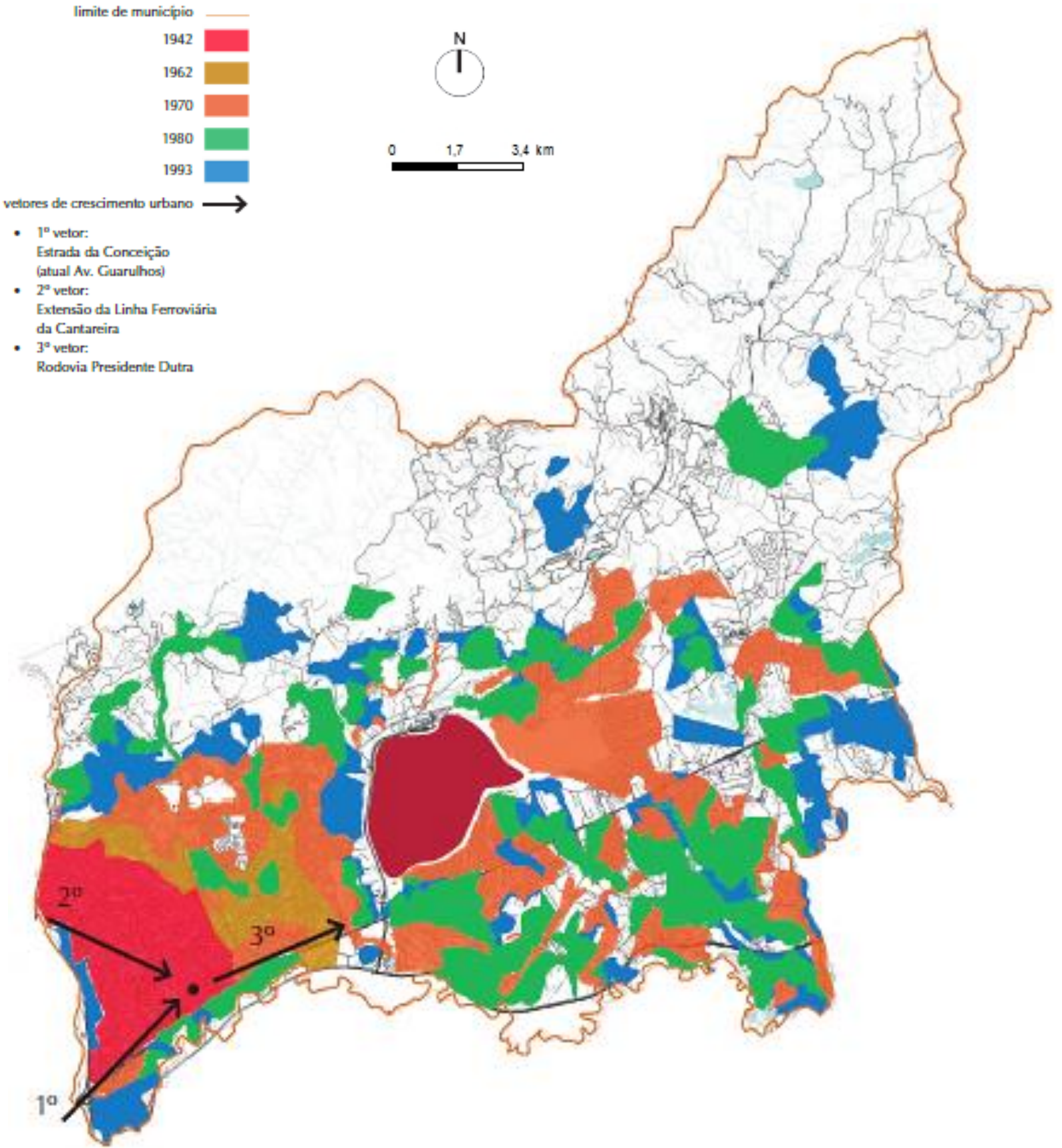

Figura 4.5 - Os três primeiros vetores de crescimento no município de Guarulhos. O primeiro e o segundo convergindo na direção do centro histórico do município e o terceiro fomentando a ocupação dispersa a partir da década de 1970 (LASALVIA, 2006).

\subsection{Transportes aéreos em São Paulo}

Na história dos transportes aéreos em São Paulo, o aeroporto de Marte foi o primeiro terminal aeroportuário de São Paulo, tendo suas atividades iniciadas em 1929. Porém, durante a revolução de 1932, o local foi atingido por bombas, além de ser palco constante de enchentes oriundas do tietê não 
retificado. Já em meados da década de 1930, torna-se um aeroporto secundário, utilizado para aviões de pequeno porte e, posteriormente, helicópteros.

O destaque fica com o Aeroporto de Congonhas, sendo ele um marco que separa a aviação realizada de maneira praticamente amadora no início da aviação em São Paulo para o início do transporte aéreo organizado no Brasil. Com isso, os pousos e decolagens deixam de ocorrer nas inúmeras pistas que havia em diversas fazendas da cidade para se concentrar na pista de Congonhas, escolhida por se localizar em uma colina com declive, o que permitia a rápida secagem da pista após as chuvas, e por estar em uma cota altimétrica elevada $(790 \mathrm{~m})$, o que facilitava sua identificação em um período onde a navegação era visual, e além de estar distante da malha urbana da cidade de São Paulo.

O Aeroporto de Congonhas, localizado na Zona Sul do município de São Paulo, foi inaugurado em 1936, passando posteriormente por uma reforma e ampliação, sendo reinaugurado em 1949. Com o rápido crescimento da cidade, o Aeroporto de Congonhas saturou-se brevemente, já em meados da década de 1960, tanto em função do crescimento na demanda por lugares que atendessem a mais passageiros e pistas que comportassem maiores aeronaves, como porque a malha urbana cercou completamente a pista do aeroporto, como pode ser visto na Figura 4.6 a seguir, o que impedia a possibilidade de ampliações significativas. 


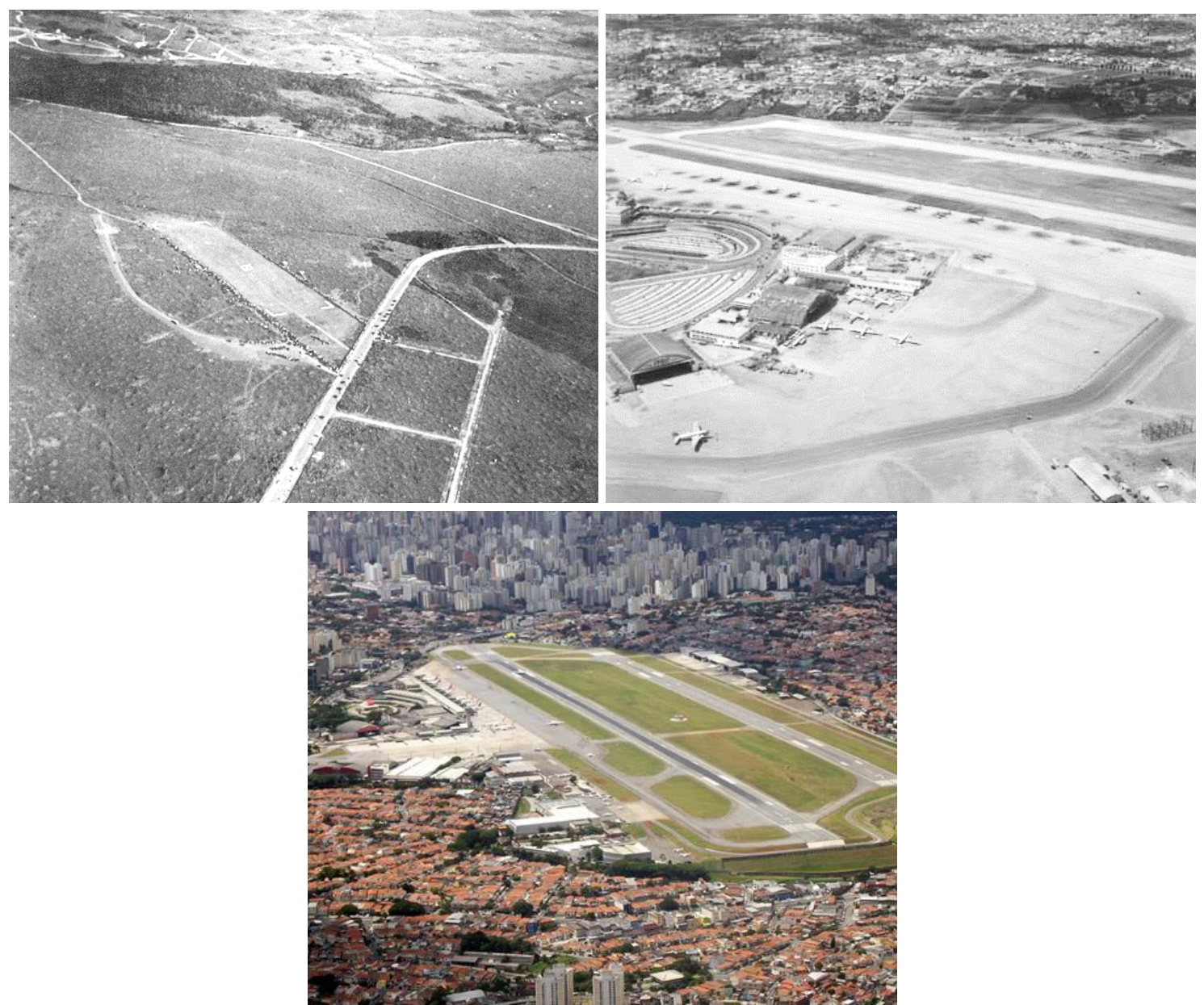

Figura 4.6 - A imagem superior esquerda destaca a pista do Aeroporto de Congonhas em meados de 1930, próximo à data de sua inauguração, ainda sem grandes terminais de passageiros e cargas. A imagem superior direita mostra a pista de Congonhas na década de 1950, logo após as obras de modernização e construção do terminal de passageiros. É possível observar no canto superior da imagem a urbanização, que já se aproxima da pista. Por fim, na imagem inferior é apresentado o atual estado do aeroporto, no qual se destaca a maneira como a cidade cresceu ao seu redor. Fonte das três imagens: IBGE, 2017.

De fato, no início da década de 1970, o aeroporto operava perto da capacidade máxima na época, com fluxo de 5,3 milhões de passageiros ao ano. Além disso, as aeronaves haviam crescido rapidamente, passando de modelos como SAAB 90 Scadia e Lockheed L-188, criados em 1946 e 1957, com comprimentos de $28 \mathrm{~m}$ e $32 \mathrm{~m}$, respectivamente, para os modernos DC-10 e Boeing 747 com $52 \mathrm{~m}$ e $60 \mathrm{~m}$ de comprimento, respectivamente. Tais aeronaves exigiam pistas superiores a $3.000 \mathrm{~m}$ de comprimento, quando a pista de Congonhas atingia $1.939 \mathrm{~m}$. E além da questão das aeronaves que vinham aumentando, também aumentava a demanda por voos e novos destinos tendiam a continuar em crescimento. 
Tanto a questão da saturação dos voos existentes, como a chegada de novas aeronaves no cenário da aviação sinalizaram a necessidade de um novo aeroporto. Após estudos que envolveram mais de 23 propostas diferentes e envolveram diversas cidades no entorno de São Paulo, optou-se em 1977 pela construção do complexo aeroportuário no bairro de Cumbica em Guarulhos. Os principais motivos dessa escolha foram a existência da base aérea da aeronáutica, baixa densidade populacional no entorno (tendo sido realizada a desapropriação de uma área habitada) e a proximidade com São Paulo, já servida por algumas vias de acesso (rodovias Presidente Dutra e Trabalhadores e av. Monteiro Lobato).

Cabe destacar para o fato de o aeroporto ter sido construído de forma modular, de modo que cada um dos 4 módulos seria capaz de atender a uma demanda de 7,5 milhões de passageiros ao ano. Com previsão de crescimento de demanda da ordem de $10 \%$ ao ano, sendo que o último módulo seria concluído em 2000, quando então atenderia a 30 milhões de passageiros ao ano.

Com isso, o Aeroporto Internacional de São Paulo foi inaugurado em 1985, e junto com ele como forma de suprir o aumento no tráfego de automóveis entre o aeroporto e a cidade de São Paulo, a rodovia dos Trabalhadores foi ampliada em 1982 e rebatizada, na década de 1990, para rodovia Ayrton Senna.

Juntamente com a instalação desses novos elementos e alocação dos novos parques industriais, o município experimentou um crescimento populacional intenso a partir da década de 1970. Este crescimento populacional pode ser observado entre os anos de 1940 e 2016 nos gráficos a seguir.

A população Guarulhense, que em 1940 era de 13.439 pessoas, chegou a 532.724 em apenas 40 anos. Nas décadas seguintes, embora a taxa de crescimento decenal tenha diminuído, a população continuou a ampliar-se rapidamente, chegando a mais de 1 milhão de habitantes em 2000 e a quase 1,5 milhão em 2016. Tais números fazem de Guarulhos a $13^{\mathrm{a}}$ cidade mais populosa do Brasil e a $53^{\mathrm{a}}$ do continente americano, conforme a Figura 4.7. 


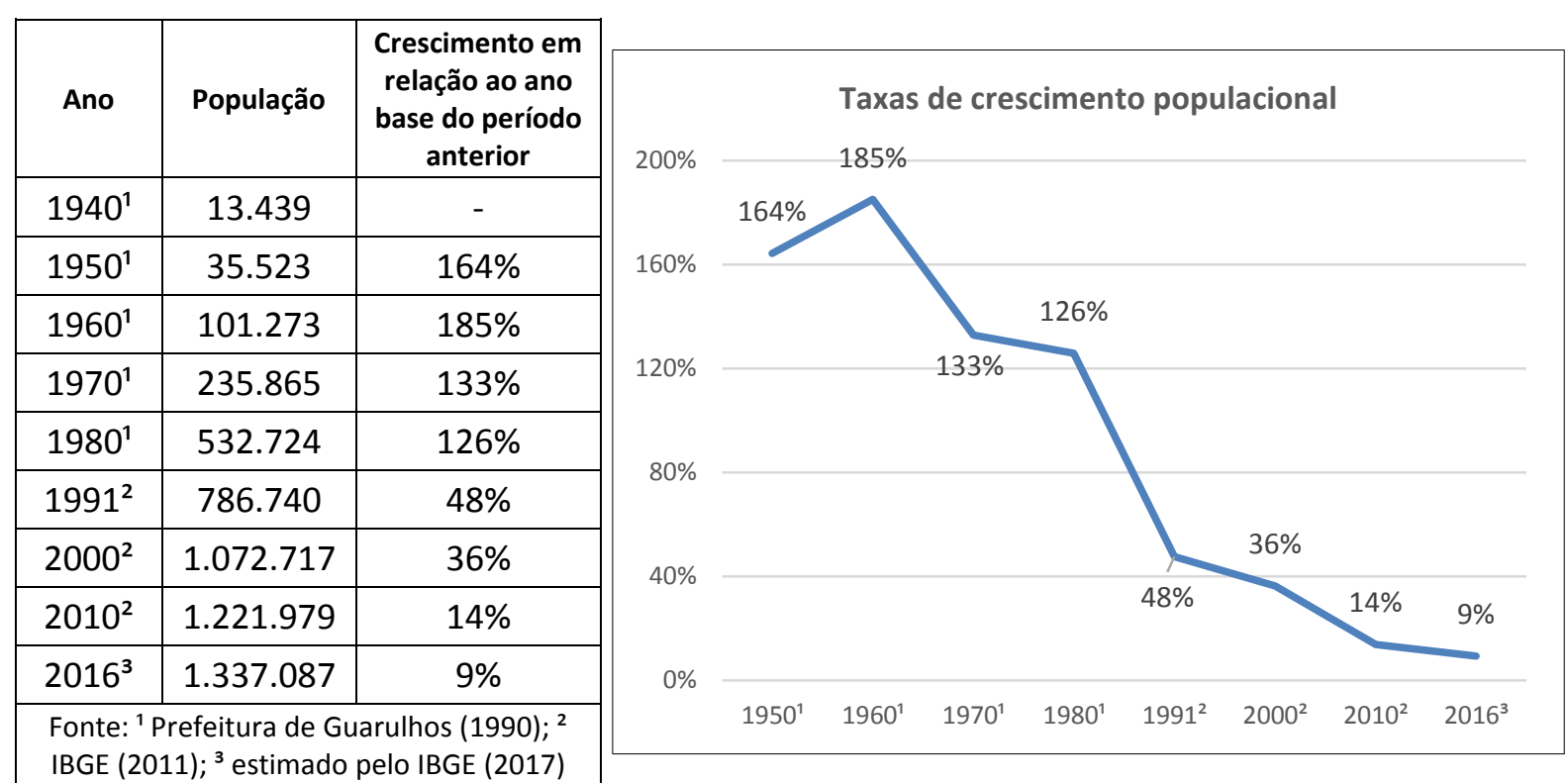

\section{Crescimento Populacional}

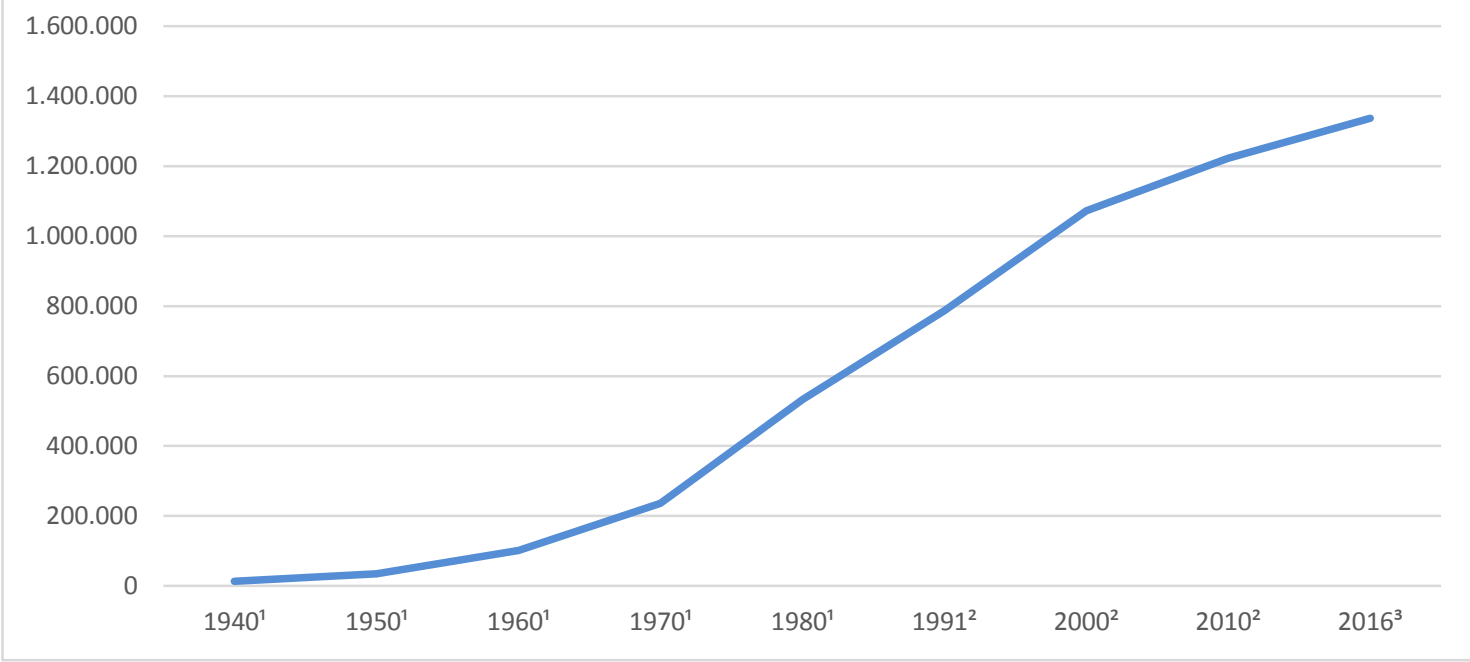

Figura 4.7 - Crescimento populacional

O Quadro A da Figura 4.8 apresenta a densidade demográfica no município de Guarulhos. Nesta figura é possível verificar que as maiores densidades demográficas estão concentradas nos bairros centrais, de origem mais antiga e a sudeste do Aeroporto de Guarulhos, nos bairros Pimentas e Presidente Dutra. De modo geral, a maior parte da população ocupa as áreas mais baixas do município. As pirâmides demográficas para 2000 e 2010 de Guarulhos mostram que a evolução populacional do município tem seguido a tendência do Brasil, que é a diminuição da base da pirâmide, o que significa o envelhecimento relativo da população. 
O Quadro B da Figura 4.8, por sua vez apresenta o rendimento médio por domicílio no munícipio de Guarulhos. Como pode ser observado, os maiores rendimentos, com rendimentos superiores aos $R \$ 4.000$ estão localizados unicamente nos bairros centrais, principalmente nos bairros Vila Galvão, Torres Tibagy, Maia, Macedo e Paraventil, além da vila militar ao sul do aeroporto. As piores situações estão nos setores a sudeste, oscilando entre $R$ \$ 937 e $R \$ 1.500$ e menos de $\mathrm{R} \$ 937$.

Considerando tais rendimentos, um dado importante que aparece no Atlas de Desenvolvimento Humano (PNUD, 2013) é que em 2010 o município tinha $1,95 \%$ dos habitantes classificados como extremamente pobres, ao passo que $6,5 \%$ deles eram pobres. Tais porcentagens representam uma pequena melhoria em relação ao período anterior, ao passo que o índice de Gini, que mede a desigualdade social, se manteve estável no período. Estes valores podem ser observados na Tabela 4.1 a seguir:

\begin{tabular}{|l|r|r|r|}
\hline & $\mathbf{1 9 9 1}$ & $\mathbf{2 0 0 0}$ & $\mathbf{2 0 1 0}$ \\
\hline Renda per capita (em R\$) & 635,29 & 694,75 & 829,91 \\
\hline \% de extremamente pobres & 1,69 & 2,58 & 1,95 \\
\hline \% de pobres & 8,75 & 10,78 & 6,50 \\
\hline Índice de Gini & 0,48 & 0,52 & 0,51 \\
\hline
\end{tabular}

Tabela 4.1 - Renda, pobreza e desigualdade em Guarulhos. IBGE, 2010. 


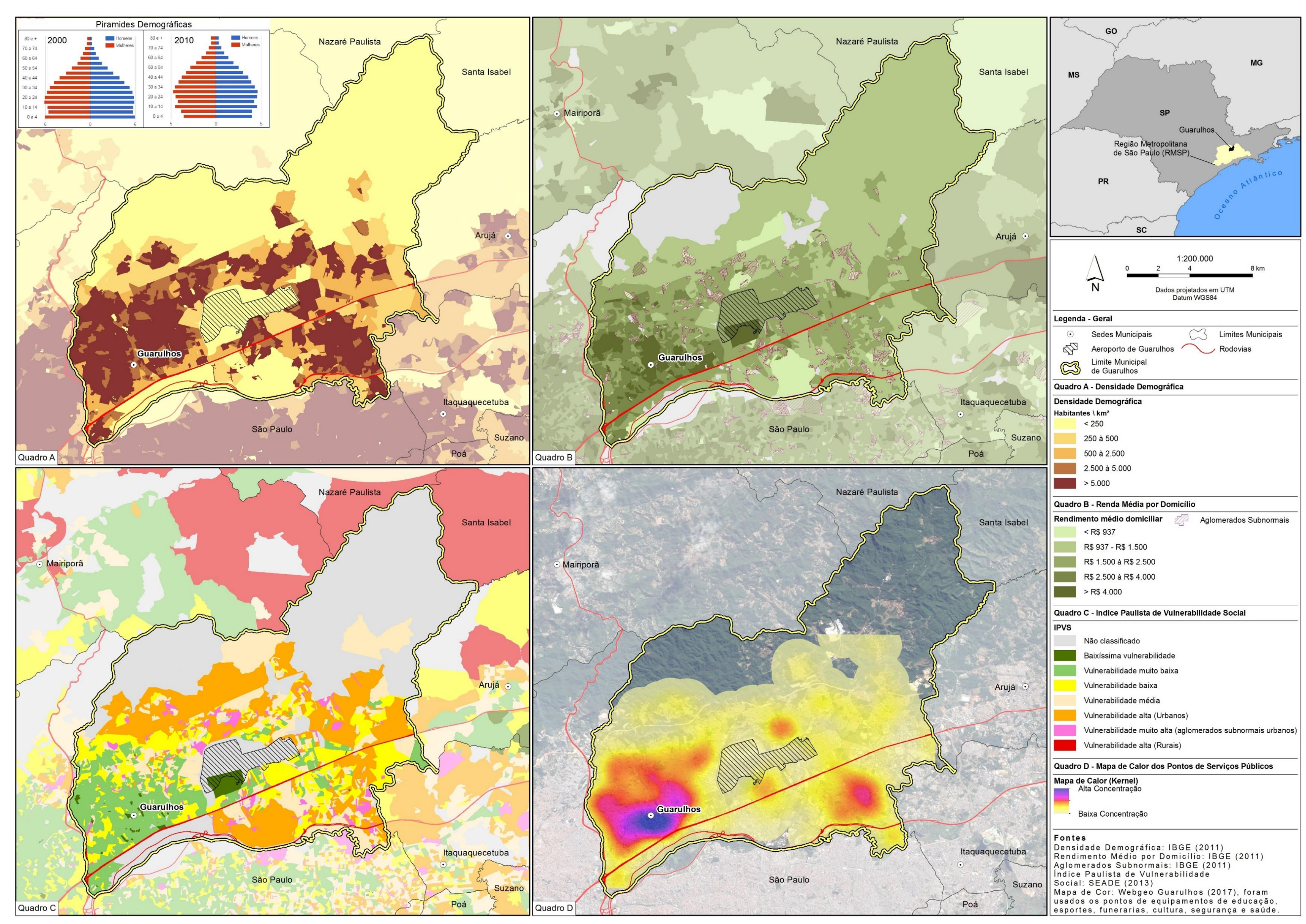

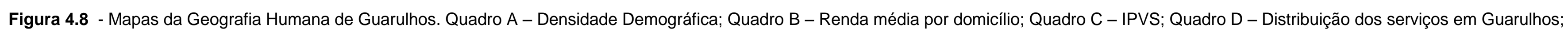


O Quadro C do mapa 4.8 apresenta o Índice Paulista de Vulnerabilidade Social (IPVS) para o município de Guarulhos. O IPVS é calculado pelo SEADE para cada setor censitário e leva em consideração informações relacionadas à escolaridade, rendimentos, saneamento básico, integrando tais variáveis em dois fatores, sendo o fator 1 relacionado aos dados socioeconômicos e o fator 2 aos dados que envolvem o ciclo de vida das famílias. Mais detalhes podem ser obtidos na metodologia da análise disponível em Seade (2010). Em termos gerais, reflete a vulnerabilidade das famílias localizadas em um determinado setor, conforme sintetizado na Tabela 4.2, a seguir.

\begin{tabular}{|c|c|c|c|c|}
\hline \multirow{2}{*}{ Grupos } & \multicolumn{2}{|c|}{ Dimensões } & \multirow{2}{*}{ IPVS2010 } & \multirow{2}{*}{$\begin{array}{c}\text { Situação e tipo de setores } \\
\text { por grupo }\end{array}$} \\
\hline & Socioeconômica & $\begin{array}{l}\text { Ciclo de vida } \\
\text { familiar }\end{array}$ & & \\
\hline 1 & Muito alta & $\begin{array}{l}\text { Familias jovens, } \\
\text { adultas e idosas }\end{array}$ & $\begin{array}{c}\text { Baixissima } \\
\text { vulnerabilidade }\end{array}$ & $\begin{array}{c}\text { Urbanos e rurais } \\
\text { não especiais e subnormais }\end{array}$ \\
\hline 2 & Média & $\begin{array}{l}\text { Familias adultas e } \\
\text { idosas }\end{array}$ & $\begin{array}{c}\text { Vulnerabilidade } \\
\text { muito baixa }\end{array}$ & $\begin{array}{c}\text { Urbanos e rurais } \\
\text { não especiais e subnormais }\end{array}$ \\
\hline 3 & Média & Familias jovens & $\begin{array}{c}\text { Vulnerabilidade } \\
\text { baixa }\end{array}$ & $\begin{array}{c}\text { Urbanos e rurais } \\
\text { não especiais e subnormais }\end{array}$ \\
\hline 4 & Baixa & $\begin{array}{l}\text { Familias adultas e } \\
\text { idosas }\end{array}$ & $\begin{array}{c}\text { Vulnerabilidade } \\
\text { média }\end{array}$ & $\begin{array}{c}\text { Urbanos } \\
\text { não especiais e subnormais }\end{array}$ \\
\hline 5 & Baixa & $\begin{array}{l}\text { Familias jovens em } \\
\text { setores urbanos }\end{array}$ & $\begin{array}{c}\text { Vulnerabilidade } \\
\text { alta }\end{array}$ & $\begin{array}{c}\text { Urbanos } \\
\text { năo especiais }\end{array}$ \\
\hline 6 & Baixa & $\begin{array}{l}\text { Familias jovens } \\
\text { residentes em } \\
\text { aglomerados } \\
\text { subnormais }\end{array}$ & $\begin{array}{c}\text { Vulnerabilidade } \\
\text { muito alta }\end{array}$ & $\begin{array}{l}\text { Urbanos } \\
\text { subnormais }\end{array}$ \\
\hline 7 & Baixa & $\begin{array}{l}\text { Familias idosas, } \\
\text { adultas e jovens em } \\
\text { setores rurais }\end{array}$ & \begin{tabular}{|} 
Vulnerabilidade \\
alta
\end{tabular} & Rurais \\
\hline
\end{tabular}

Tabela 4.2 - Tabela de interpretação do Índice Paulista de Vulnerabilidade Social

No caso de Guarulhos é marcante que os setores com a melhor classificação orbitam as áreas relacionadas aos bairros de origem do município, na porção sudoeste do município, onde a maior parte dos setores censitários correspondem ao grupo 2, com vulnerabilidade muito baixa, sendo ocasionalmente interrompidos por setores em situação melhor (grupo 1 baixíssima vulnerabilidade) ou pior (grupo 3 - vulnerabilidade baixa). A situação decai visivelmente nas porções norte e leste do município, justamente nos locais que foram ocupados no período de rápido crescimento populacional a partir da 
década de 1980. Ali a maior parte dos setores censitários está classificada no grupo 3 - vulnerabilidade baixa e 5 - vulnerabilidade alta, sendo frequentemente alternados com setores no grupo 4 - vulnerabilidade média e 6 - vulnerabilidade muito alta. Além disso, como pode ser observado, os domicílios subnormais estão concentrados nas áreas de maior vulnerabilidade.

Por fim, o Quadro D da figura 4.8 apresenta um mapa obtido pelo algoritmo Kernel sobre os pontos com a localização de equipamentos de serviços diversos, como saúde, educação, cultura, segurança e esportes. Esta figura reflete fortemente as variáveis observadas anteriormente e apresentam a maior concentração destes serviços na região central do município, o que faz com que esta área demande grandes quantidades de mão de obra.

No que se refere ao Produto Interno Bruto do município, Guarulhos destaca-se como a $2^{\text {a }}$ cidade mais importante da RMSP, atrás apenas da cidade de São Paulo, sendo ainda o 4 PIB do estado e o 13ํำ do país. A composição do PIB é apresentada na Tabela 4.3, a seguir, em que se pode observar a predominância do setor de serviços que compõe $63 \%$ do PIB municipal, seguido por $26 \%$ correspondentes ao PIB oriundo da indústria.

\begin{tabular}{|c|c|c|c|c|c|c|}
\hline \multirow[b]{2}{*}{ Unidade } & \multicolumn{4}{|c|}{ Valor Adicionado (R\$) } & \multirow[b]{2}{*}{ PIB Total (R\$) } & \multirow{2}{*}{$\begin{array}{c}\text { PIB per } \\
\text { Capita (R\$) }\end{array}$} \\
\hline & Agropecuária & Indústria & Serviços & $\begin{array}{l}\text { Administração } \\
\text { Pública }\end{array}$ & & \\
\hline \multirow{2}{*}{ Guarulhos } & 37.614 & 11.201 .740 & 27.218 .427 & 4.488 .096 & 42.945 .877 & \multirow{2}{*}{$39.162,96$} \\
\hline & $0,09 \%$ & $26 \%$ & $63 \%$ & $10 \%$ & $100 \%$ & \\
\hline \multirow{2}{*}{$\begin{array}{c}\text { São Paulo } \\
\text { (Cidade) }\end{array}$} & 39.801 & 66.843 .382 & 410.722 .122 & 37.866 .470 & 515.471 .775 & \multirow[b]{2}{*}{$52.796,78$} \\
\hline & $0,01 \%$ & $12,97 \%$ & $79,68 \%$ & $7,35 \%$ & $100,00 \%$ & \\
\hline
\end{tabular}

Tabela 4.3 - PIB e Valor Adicionado em Guarulhos. IBGE, 2010. 


\section{Material e Métodos}

\subsection{Procedimentos Metodológicos}

O primeiro conjunto de etapas foi conduzido com objetivo de compor um banco de dados, contendo informações relevantes que pudessem ser obtidas junto aos órgãos oficiais, às universidades, aos institutos, entre outros. Os arquivos obtidos foram sempre avaliados quanto à sua qualidade e topologia (existência de fendas e sobreposição entre os polígonos, linhas abertas, entre outros), e então sendo posteriormente inseridos no banco de dados.

De modo geral, estes referidos dados estão sintetizados no organograma da Figura 5.1, apresentada a seguir. Foram inseridos no banco os dados processados da planialtimetria em escala de 1:50.000 do IBGE (1980), o quais foram em seguida interpolados e transformados em mapas de declividade e altimetria. Da mesma forma, as imagens aéreas que foram obtidas no decorrer da pesquisa foram registradas e/ou georreferenciadas para serem adicionadas ao banco. Por fim, os dados oriundos da prefeitura e outros órgãos oficiais foram diretamente incluídos no banco de dados.

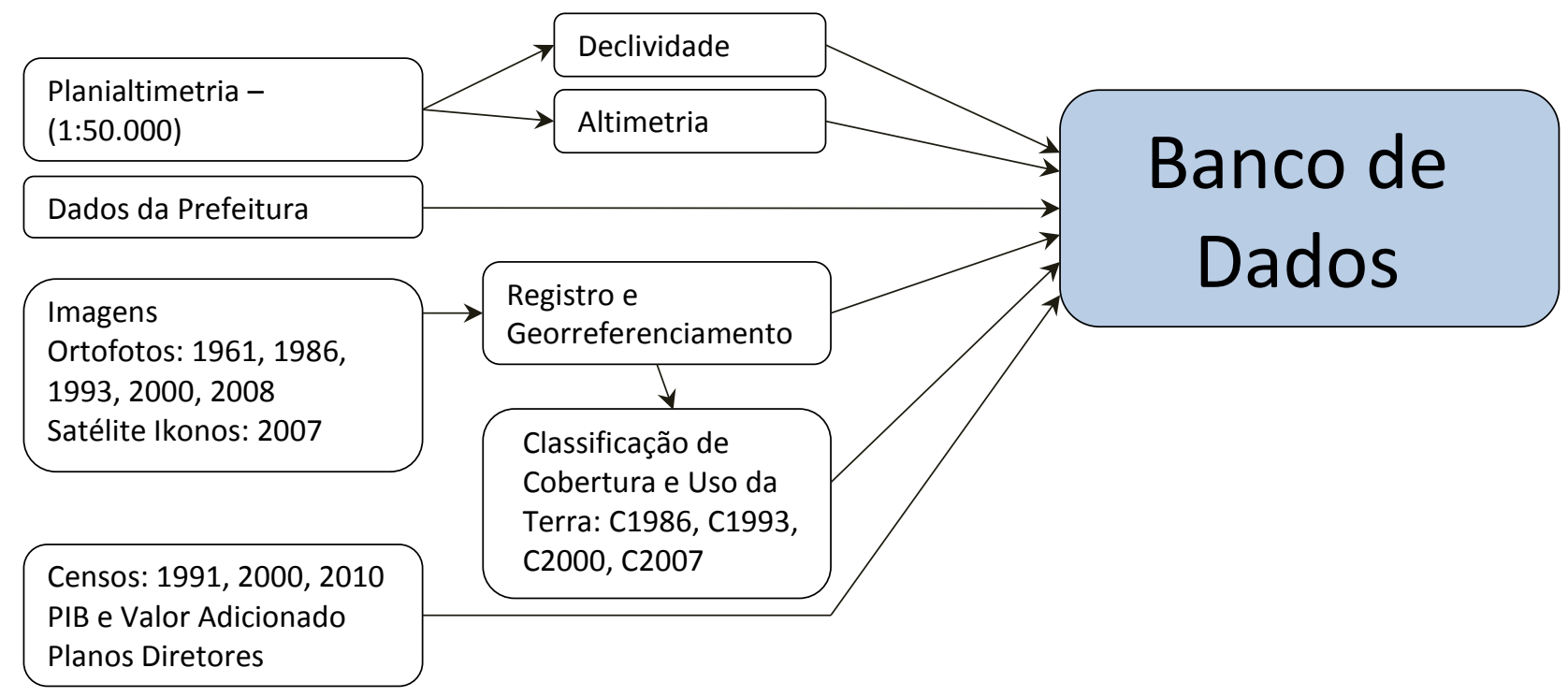

Figura 5.1 - Construção do banco de dados

A Tabela 5.1 a seguir, apresenta um compilado dos elementos principais que compõem o banco de dados criado nas primeiras etapas do projeto. 


\begin{tabular}{|l|c|c|c|c|c|}
\hline \multicolumn{1}{|c|}{ Dado } & Ano & Projetado? & Metadado & $\begin{array}{c}\text { Forma } \\
\text { to }\end{array}$ & $\begin{array}{c}\text { Fornecido por / } \\
\text { Origem }\end{array}$ \\
\hline Aerofotografia & 1961 & Não & Não & Raster & LASERE/USP \\
\hline Aerofotografia & 1986 & Não & Não & Raster & UNG \\
\hline Aerofotografia & 1993 & Não & Não & Raster & UNG \\
\hline Aerofotografia & 2000 & Não & Não & Raster & UNG \\
\hline lkonos & 2007 & Sim & Não & Raster & UNG \\
\hline Ortofoto & 2008 & Sim & Não & Raster & UNG \\
\hline Limites Municipais & 2015 & Sim & Sim & Vetor & IBGE (2013) \\
\hline Logradouros & 2008 & Sim & Sim & Vetor & CEM \\
\hline Setor Censitário e Censo & 2010 & Sim & Sim & Vetor & IBGE (2011) \\
\hline Planialtimetria & - & Sim & Sim & Vetor & IBGE (1980) \\
\hline PlB/ Valor Adicionado & 2016 & Não & Sim & Tabela & IBGE \\
\hline Planos Diretores & - & Não & Sim & Texto & Pref. Guarulhos \\
\hline Bases Geoambientais & 2008 & Não & Sim & Textos & UNG \\
\hline Bairros de Guarulhos & 2008 & Sim & Sim & Vetor & Pref. Guarulhos (2008) \\
\hline Equipamentos de Saúde & 2008 & Sim & Sim & Vetor & Pref. Guarulhos (2008) \\
\hline Equipamentos de Esportes & 2008 & Sim & Sim & Vetor & Pref. Guarulhos (2008) \\
\hline Equipamentos de Cultura & 2008 & Sim & Sim & Vetor & Pref. Guarulhos (2008) \\
\hline Equipamentos de Segurança & 2008 & Sim & Sim & Vetor & Pref. Guarulhos (2008) \\
\hline Unidades de Conservação & 2012 & Sim & Sim & Vetor & MMA (2012) \\
\hline Precipitação e Temperatura & 2016 & Sim & Sim & Vetor & INMET (2017) \\
\hline Geomorfologia & 2006 & Sim & Sim & Vetor & Ross (2006) \\
\hline
\end{tabular}

Tabela 5.1 - Descrição dos principais dados inseridos para composição do banco de dados utilizado no projeto

Para Almeida (2004) a escolha dos períodos modelados seria ideal se acompanhasse a configuração de circunstâncias mais ou menos homogêneas que são geradoras de modificações na paisagem, como o efeito de determinadas políticas públicas, cenários macroeconômicos favoráveis, ou mesmo a implantação de grandes obras estruturais.

A despeito disso, são frequentes os casos em que a seleção dos períodos a serem modelados ocorre em função do material disponível para a análise, normalmente relacionado à inexistência de mapeamentos pretéritos de cobertura e uso da terra na escala pretendida ou indisponibilidade de imagens com resolução espacial adequada.

Felizmente no caso de Guarulhos os levantamentos aerofotogramétricos existentes obedecem a uma periodicidade aproximadamente decenal, havendo imagens aéreas para os anos de 1961, 1972, 1985, 1993, 2000 e 2008. Isso tornou possível selecionar os períodos posteriores à implantação do aeroporto na cidade, de 1985 em diante, revelando as modificações na paisagem após este marco histórico. 
Os principais processamentos realizados para agregar os elementos ao banco de dados serão descritos em pormenor a seguir, nas Seções 5.1.1 Registro das Imagens, 5.1.2 - Classificação das Imagens e 5.2.3 Processamento da Planialtimetria.

Uma segunda etapa para o tratamento dos dados foi necessária para preparar as variáveis que seriam utilizadas na etapa de modelagem com o software Dinamica-EGO e envolveu o processamento de algumas das bases preparadas na primeira etapa. A Figura 5.2 a seguir apresenta os passos realizados para a composição da base para modelagem, bem como os passos realizados dentro do software Dinamica-EGO.

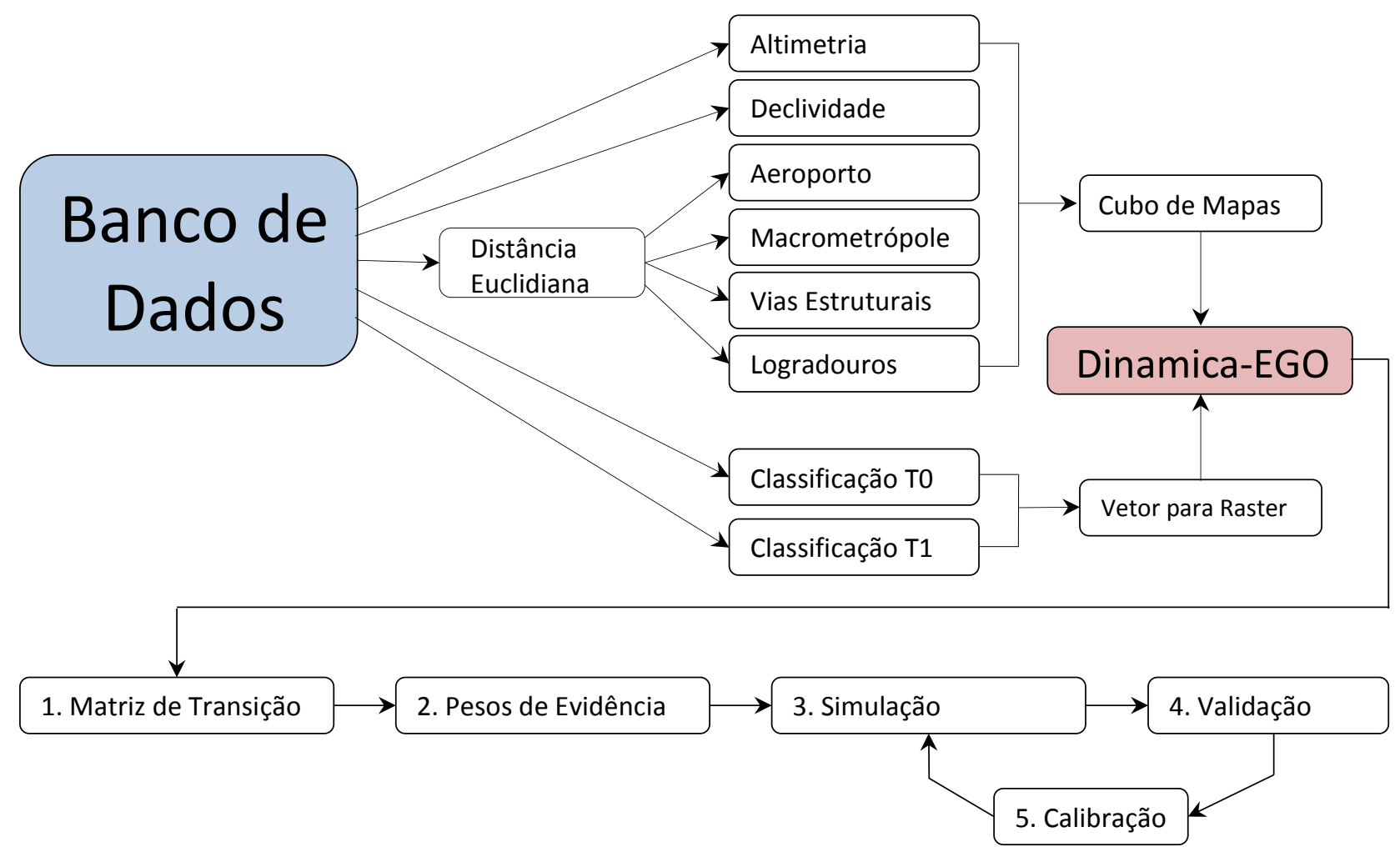

Figura 5.2 - Fluxo metodológico de preparação das bases para a modelagem e da modelagem em cada período analisado. T0 e T1 se referem aos mapas de cobertura e uso da terra inicial e final

Os processamentos realizados para a composição do banco de dados estão descritos nas seções 5.1.4 - Processamento dos Dados Planialtimétricos, 5.1.5 - Processamento dos Dados Vetoriais, 5.1.6 - Conversão das Classificações de Cobertura e Uso da Terra e 5.1.7 - Etapas de construção do modelo no Dinâmica-EGO. 


\subsubsection{Registro das Imagens}

Durante a etapa de avaliação das imagens, observou-se uma discrepância da imagem IkONOS-2 em relação às bases cartográficas vetoriais e cartas topográficas do IBGE, resultando em $75 \mathrm{~m}$ de deslocamento na direção sudoeste, sendo mais visível no setor sul, no limite com o rio Tietê.

A correção foi realizada com um procedimento de registro da imagem, a partir da sua sobreposição à carta topográfica, utilizando pontos notáveis, facilmente identificados nas duas camadas. Foram usados cinco pontos de registro e a imagem foi adequadamente reposicionada, conforme pode ser observado na Figura 5.3.

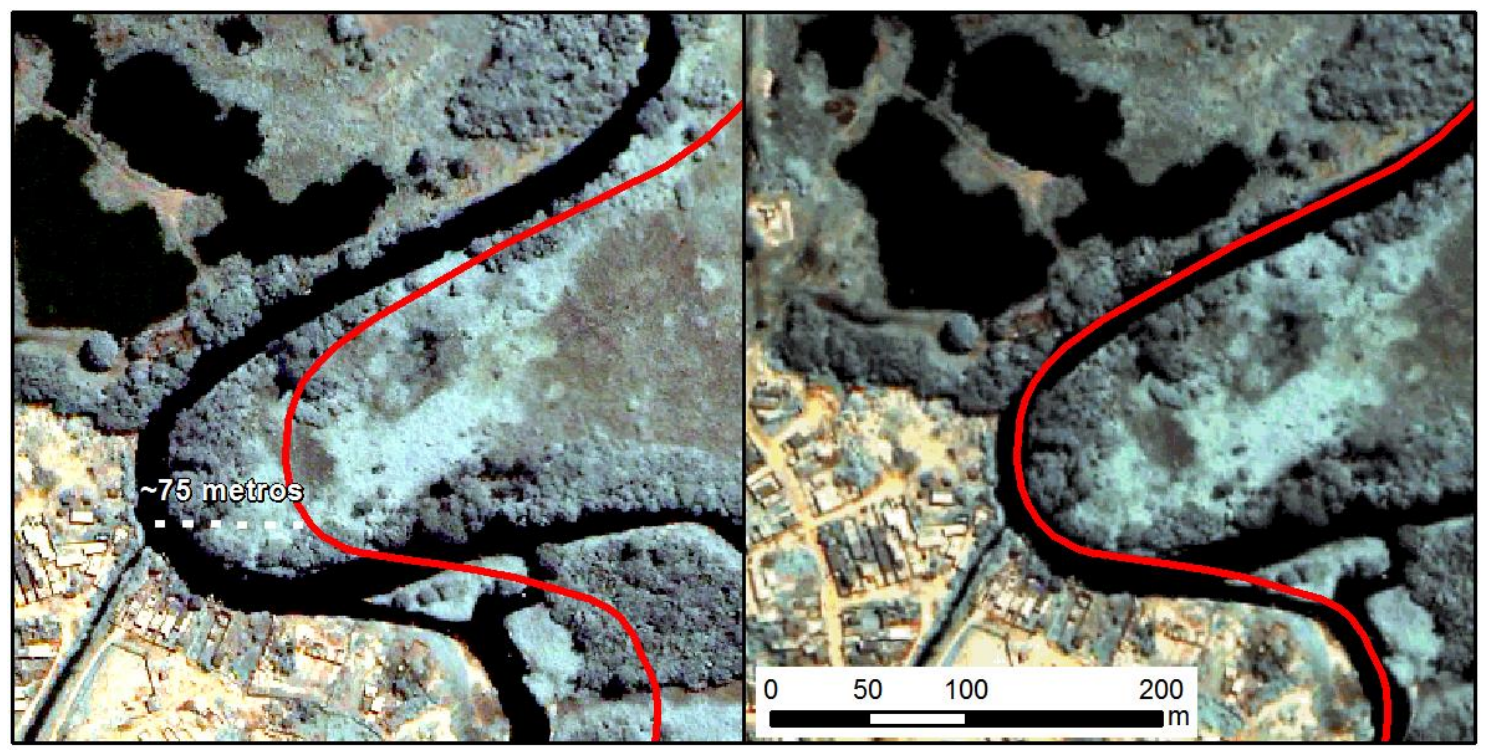

Figura 5.3 - À esquerda, apresenta-se a imprecisão em relação ao limite do município (linha em vermelho) no eixo do rio Tietê. À direita, a imagem Ikonos-2 registrada, na qual o problema foi corrigido.

Uma vez corrigido o erro atestou-se, a compatibilidade entre as ortofotos de 2008 e a imagem Ikonos de 2007, e a partir daí ambas foram utilizadas como referência para realizar o georreferenciamento das aerofotografias dos anos precedentes.

As imagens aéreas de 1986, 1993 e 2000 são coleções analógicas, para as quais não foram preservados os metadados necessários à correta ortorretificação. Sendo assim, para elaborar mapas de cobertura e uso da terra destes períodos, elas foram georreferenciadas uma a uma, buscando-se a máxima acurácia visual, sempre priorizando a alocação dos pontos em texturas 
e padrões com desenhos lineares. O menor número de pontos necessário para georreferenciar uma foram 4 pontos, sendo 16 a quantidade máxima. Cada imagem foi exportada no formato Geotiff, e as mesmas foram agregadas para se compor um mosaico para cada ano.

Como este procedimento não fornece uma imagem ortorretificada, as imagens foram usadas como uma referência na identificação das alterações ocorridas na paisagem, como será visto na seção a seguir.

\subsubsection{Classificação das Imagens}

De início percebeu-se que não seria possível aplicar a classificação de imagem baseada em objeto como havia sido proposto na fase de desenvolvimento do projeto deste trabalho. A técnica mencionada funciona bem quando são usadas imagens de satélite com bandas distintas, o que auxilia tanto na etapa de segmentação quanto na de classificação. Contudo, a imagem Ikonos-2 obtida sofreu a fusão das bandas, o que suprimiu o conteúdo de cada uma das bandas separadamente, e consequentemente não houve condições para se realizar a segmentação e extração das informações da imagem como pretendido. Os resultados iniciais com a segmentação da imagem lkonos-2 já mostraram que a classificação baseada em objeto seria uma técnica inviável para este caso.

Com isso, todas as classificações foram conduzidas manualmente por meio do método de análise visual da imagem, segmentação e identificação manual das classes.

Como mencionado na seção anterior, desde o início houve a preocupação de com relação a disparidades observadas entre produtos de anos distintos, principalmente por conta da qualidade geométrica das imagens de 2000, $1993 \mathrm{e}$ 1986. O procedimento adotado em definitivo para sanar este problema está descrito a seguir:

1- Uma vez que a imagem Ikonos-2 era a referência geométrica, ela foi utilizada para a primeira classificação. A partir de um polígono com os limites municipais, procedeu-se ao recorte das classes e posterior identificação. 
2- Após a classificação de 2007, copiou-se o resultado e o mesmo foi renomeado para a classificação de 2000 . Estes novos polígonos foram sobrepostos às imagens do ano de 2000, e as áreas em que houve transição foram destacadas. Para se desenhar o recorte dessas áreas sem acarretar imperfeições existentes na imagem não ortorretificada, foi utilizada a geometria da imagem de 2007. Por exemplo, uma área urbana, que aparecia como lote desocupado na imagem de 2000, teve seus limites identificados, e o recorte seguiu a geometria existente na imagem de 2007. Este procedimento foi repetido para os demais anos, inicialmente para 1993, e em seguida, para 1986.

Assim, a imagem de 2007 pode ser considerada a referência espacial, ao passo que as demais são a referencial temporal.

De modo geral, a escala de visualização para a identificação das classes foi fixada entre 1:2.000 e 1:8.000, de modo a manter coerência em relação à pretensão do resultado final: um mapeamento compatível com a escala $1: 10.000$.

A principal vantagem da rotina descrita é que as distorções ocasionadas pelo registro de imagens foram drasticamente reduzidas e, como resultado, temse um conjunto de vetores multi-temporais, de modo que entre um ano e outro só diferem as classes que sofreram transição.

A Figura 5.4 apresenta a chave de interpretação utilizada, destacando a aparência das classes visualizadas em solo, o padrão e a textura na imagem aérea e a descrição que se utilizou para proceder à identificação. Para mapear as classes de cobertura e uso, foram consideradas as formas, texturas, cores, localização e adjacências. A chave apresentada foi adaptada a partir da proposta de Monteiro (2008) para mapeamentos de detalhe em escala de 1:10.000.

É necessário ainda mencionar que as fotografias de superfície disponíveis no módulo Google Street View do GoogleEarth (GOOGLE, 2016) foram largamente utilizadas no decorrer do processo de classificação, a fim de sanar dúvidas que surgiram no decorrer do mapeamento. Além disso, a distinção entre áreas regulares e irregulares leva em conta apenas a avaliação visual, já que não estavam disponíveis as informações cadastrais para todos os períodos. 
Para avaliar a qualidade do mapeamento de 2007, foram gerados 50 pontos aleatórios para cada classe de cobertura e uso da terra (exceto aeroporto, rodovias e espelhos d'água, que apresentam limites claramente definidos). $\mathrm{Na}$ sequência, em cada um dos pontos, foi feita uma verificação com coleta de informações em gabinete, por meio da imagem ortorretificada com maior detalhe de 2008, ou em campo, que, somadas, formaram as informações de verdade de campo. O cruzamento entre as classes assim coletadas e as obtidas diretamente da classificação foi realizada por meio do índice Kappa.

Como era de se esperar, o procedimento foi aplicado apenas ao mapeamento de 2007, em função da disponibilidade de dados e da possibilidade de se verificar em campo as dúvidas que surgiram quanto a algumas classes.

\subsubsection{Organização e Processamento da Base de Dados}

Segundo consta no manual do Dinamica-EGO, o software processa unicamente imagens em formato matricial (raster) com Sistemas de Coordenadas Geodésicas ou UTM e Datum WGS84, Córrego Alegre ou SAD69.

Como Guarulhos situa-se integralmente dentro do Fuso 23, variando entre as longitudes $46,35^{\circ}$ e $46,57^{\circ}$ a oeste, o primeiro passo foi converter todas as bases para o sistema UTM e Datum WGS84. O segundo passo foi a conversão dos dados vetoriais em matrizes (raster). Todos os procedimentos para preparar os dados que seriam utilizados no modelo são minuciosamente apresentados no Apêndice A.

\subsubsection{Processamento dos Dados Planialtimétricos}

Foi utilizada a planialtimetria das cartas de 1:50.000 do IBGE (1980), disponível nas cartas Guarulhos (SF23-Y-C-III-4), Itaquaquecetuba (SF23-Y-DI-3) e São Paulo (SF23-Y-C-VI-2). Tais dados estão disponibilizados em formato vetorial e foram processados por um interpolador com objetivo de gerar um modelo digital do terreno (MDT) com pixels de $25 \mathrm{~m}^{2}$, sendo esta a base de altimetria necessária. 
Em seguida, foi aplicado nesta base um algoritmo para gerar as declividades do município, fornecidas em porcentagem de inclinação e mantendo-se os pixels com $25 \mathrm{~m}^{2}$.

\subsubsection{Processamentos dos Dados Vetoriais Temáticos}

Para se utilizar os vetores temáticos como variáveis no Dinamica-EGO também foi necessário convertê-los em dados matriciais, utilizando valores discretos ou contínuos conforme o caso.

Neste estudo foram usados dados oriundos do sistema viário de Guarulhos e seus entornos, o próprio aeroporto, as áreas urbanas e industriais e as pontes sobre o rio Tietê, que dão acesso ao setor sul do município.

Para converter tais dados em formato raster, foi calculada a distância euclidiana, no qual cada pixel assume como valor a distância em linha reta até a feição em questão mais próxima. Em seguida, foi gerado um cubo de mapas com todos estes mapas, de modo a integrar todas as bases temáticas em um único arquivo. A sequência desses passos está descrita minuciosamente na Seção 5.2 do Apêndice $A$.

\subsubsection{Conversão das Classificações de Cobertura e Uso da Terra}

Os vetores com os mapeamentos de cobertura e uso da terra foram convertidos em formato raster com pixels de $25 \mathrm{~m}^{2}$ e 13 classes, como descritas a seguir: 0-Nulo, 1-Urbano Regular, 2-Urbano Irregular, 3-Urbano rural, 4Loteamento Desocupado, 5-Indústria/ Galpão, 6-Mata, 7-Campo/ Capoeira, 8Agricultura, 9-Corpo d'Água, 10-Rodovias, 11-Mineração e 12-Aeroporto. Como o resultado precisa ser um quadro completo, a classe 0 se refere aos pixels fora do município de Guarulhos.

Para evitar a existência de transições espúrias entre as classes, após a conversão para raster, as bases foram submetidas a um procedimento de tabulação cruzada, para cada período de análise, conforme detalhado na Seção 7.2 do Apêndice A. Assim, ao final desse processamento, para o período de 1986 a 1993, obteve-se a classificação de 1986 e a classificação corrigida de 1993; no período seguinte, a classificação de 1993 e a classificação corrigida de 2000, 
e para o último período, produziu-se a classificação de 2000 e a classificação corrigida de 2007.

\subsubsection{Etapas de Construção do Modelo no Dinamica-EGO}

\section{Matriz de Transição}

Uma vez que os mapas de cobertura e uso da terra estejam corrigidos, é preciso obter as variáveis de entrada do modelo Dinamica-EGO. O primeiro passo é calcular a matriz de transição que irá determinar a taxa de alteração líquida da paisagem, ou seja, qual a porcentagem de alteração para cada classe.

De forma geral, a matriz de transição descreve um sistema que muda em intervalos ou passos regulares, sendo que estes passos de tempo são definidos pelo usuário, seja em dias, semanas, meses ou anos, de acordo com a temática estudada. A taxa de transição tanto pode ser fixa como flutuante, ao ser utilizada como retroalimentação do modelo.

Com isso, foram geradas as matrizes de transição para os três intervalos ou períodos de simulação analisados, a saber: 1985-1993, 1993-2000 e 20002007.

\section{Cálculo dos Pesos de Evidência}

No Dinamica-EGO, o método de pesos de evidência, baseado no teorema de Bayes, trata da probabilidade condicional, ou seja, a probabilidade de um dado evento ocorrer, dado que uma evidência (que é independente) já ocorreu.

É utilizado para produzir os mapas com a probabilidade de transição, ou seja, mapas que representam as áreas mais favoráveis para ocorrer as transições de cobertura e uso da terra, sendo as classes de cobertura e uso da terra também chamadas de estado. Enquanto as matrizes de transição quantificam o quanto houve de alteração em cada iteração, os pesos de evidência indicam os locais onde ela provavelmente ocorrerá.

O cálculo consiste de um método bayesiano e representa a influência de cada faixa de valores das variáveis estáticas e dinâmicas na transição de um estado $i$ para outro estado $j$. 


\section{Função Expander e Patcher}

No intuito de expandir as manchas de cobertura e uso da terra do mapa, bem como gerar novas manchas, o Dinamica-EGO conta com as funções de alocação de transição denominadas expander (expansor de manchas) e patcher (formador de manchas), que atuam para que isso ocorra de modo específico.

Nos dois casos, conforme descrito em Soares-Filho et al. (2007), um mecanismo nucleador de manchas irá operar sobre o mapa de probabilidades de transição, tendo como parâmetro de entrada o índice de isometria (adimensional), a variância e o tamanho médio das manchas, estes dois últimos fornecidos em hectares (ha).

Para cada uma das transições existentes em dado período de análise, foi elaborado um mapa que destacou as áreas em que houve tais mudanças, como pode ser visto na Figura 5.5 a seguir, referente à transição de Loteamentos para Urbano Regular. O mapa é criado a partir da tabulação cruzada que indica todas as transições e permanências de classes possíveis.

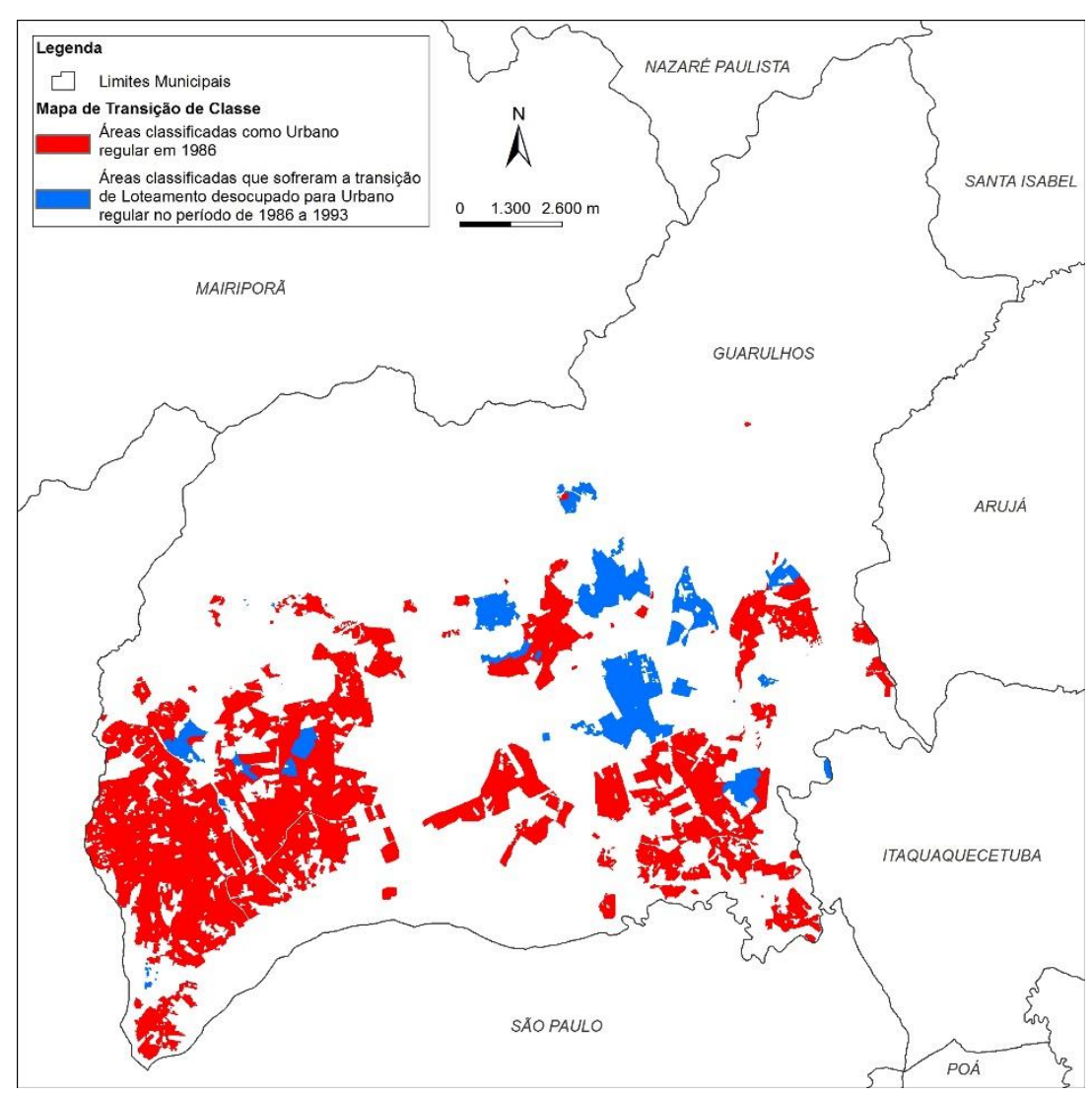

Figura 5.5 - Mapa para a transição de Loteamentos desocupado para Urbano Regular. 
Foram destacadas apenas as informações de interesse e que estão marcadas com as cores preto e vermelho. Em preto, estão marcados todos os pixels que pertencem à classe Urbano Regular por qualquer origem, ou seja, todos aqueles que estavam classificados assim em 1986 e permaneceram assim em 1993, além de todos aqueles que transitaram para essa classe por qualquer origem, exceto a partir dos Loteamentos. Em preto, estão os pixels da transição específica de Loteamento para Urbano Regular.

Com isso, foi possível estimar os parâmetros de patchere expander. Além disso, também foram calculados os parâmetros de área média, variância e índice de isometria de cada transição, que irão responder, respectivamente, pela dimensão das alterações, disposição das manchas geradas em relação à vizinhança e grau de compacidade das manchas. Os métodos para cálculo dos parâmetros iniciais de patcher e expander, bem como as demais variáveis, estão descritos na Seção 7.2 do Apêndice A.

\section{Simulação e Calibração do Modelo}

Neste ponto da modelagem, conforme destacado no organograma da Figura 5.2, chega-se a um ciclo que passa de uma simulação para a avaliação dos resultados, e então, retorna-se à simulação, alterando-se pouco a pouco os parâmetros utilizados, pois estes tendem a convergir após sucessivas etapas iterativas de ajuste.

Assim, tendo as variáveis de entradas (mapas de cobertura e uso da terra $T_{0}$ e $T_{1}$ ), o cubo de mapas, a matriz de transição, os pesos de evidência e os parâmetros para os algoritmos de alocação de transição patcher e expander, foi montado o modelo de simulação conforme apresentado na Seção 7.3 do Apêndice A.

De um modo geral, a variação dos parâmetros segue um padrão empírico de tentativa e erro, que leva em conta a maneira como as manchas foram formadas e a área que elas se desenvolveram. A manipulação dos parâmetros pode seguir as seguintes indicações: 
A soma do patcher e do expander é igual a 1, assim é possível aumentar um ou outro de acordo com a necessidade de se formar novas manchas ou de se expandir as já existentes. A área média indica o tamanho das manchas que serão ampliadas ou formadas, e este parâmetro deve ser alterado para mais ou para menos de acordo com a necessidade de se ampliar ou diminuir as manchas formadas. A variância diz respeito à variabilidade do tamanho das manchas, e quanto maior esse parâmetro, maior a tendência de se produzirem novas manchas na paisagem. Por fim, o índice de isometria, que varia entre 0 e 2, deve ser diminuído quando se deseja obter uma mancha mais disforme, ou então, aumentado quando se deseja gerar manchas mais compactas (i.e., mais próximas a formas geométricas estáveis, como círculo, quadrado, retângulo). Por default, às manchas urbanas atribui-se um valor de isometria de 1,5 e às demais, de 1.

\section{Validação do Modelo}

A primeira simulação foi validada utilizando-se uma abordagem de decaimento exponencial disponibilizada no Dinamica-EGO, conforme apresentada na Seção 7.7 do Apêndice A, a qual irá comparar dois mapasdiferença, resultantes, por um lado, da subtração entre os mapas reais em $T_{1} \mathrm{e}$ $\mathrm{T}_{0}$, e por outro lado, entre o mapa simulado em $\mathrm{T}_{1}$ e o mapa real em $\mathrm{T}_{0}$. Esta função utiliza um método de similaridade fuzzy, que considera a incerteza da localização de uma categoria dentro da vizinhança de uma célula e calcula a similaridade para um conjunto de janelas com diferentes resoluções, a saber $3 \times 3$, $5 \times 5,7 \times 7,9 \times 9$ e $11 \times 11$ pixels.

É importante destacar que, além da validação por meio de um método matemático, é importante avaliar o resultado visualmente. Isso porque o método de validação por múltiplas resoluções não considera a morfologia da paisagem, mas tão somente a frequência de distribuição de células corretamente simuladas dentro do alcance das distintas janelas de vizinhança.

É comum, muitas vezes, que uma mancha surja em uma área próxima à mancha real em $T_{1}$ e ainda com área e aparência similar, porém, por estar além dos limites da máxima janela de vizinhança, não influenciará positivamente no 
resultado da validação. A avaliação visual, contudo, indicará que o surgimento da mancha nesta área permite, por exemplo, manter a mesma análise quanto aos vetores de crescimento elaborado para o mapa real, além de indicar que as variáveis utilizadas foram o bastante para a produção de um resultado coerente. 


\section{Resultados}

\subsection{Validação do Mapeamento de 2007}

Foram gerados 50 pontos aleatórios para cada classe e em seguida foi realizado um procedimento de intersecção entre estes pontos e o mapa classificado, tendo como resultado as classes do mapa classificado. Em seguida seguiu-se a interpretação sobre as ortofotografias de 2008, com resolução submétrica, tendo como resultado a obtenção de classes baseadas em uma imagem mais precisa.

Além disso, no início da pesquisa, foi realizado um trabalho de campo preliminar, que teve como objetivo obter fotografias em nível do solo para ajudar no processo de classificação. Embora tenham sido coletados poucos pontos (13), e em período posterior à classificação, eles foram incorporados ao conjunto total.

Os pontos utilizados para a formação do índice Kappa estão apresentados na Figura 6.1 a seguir. 


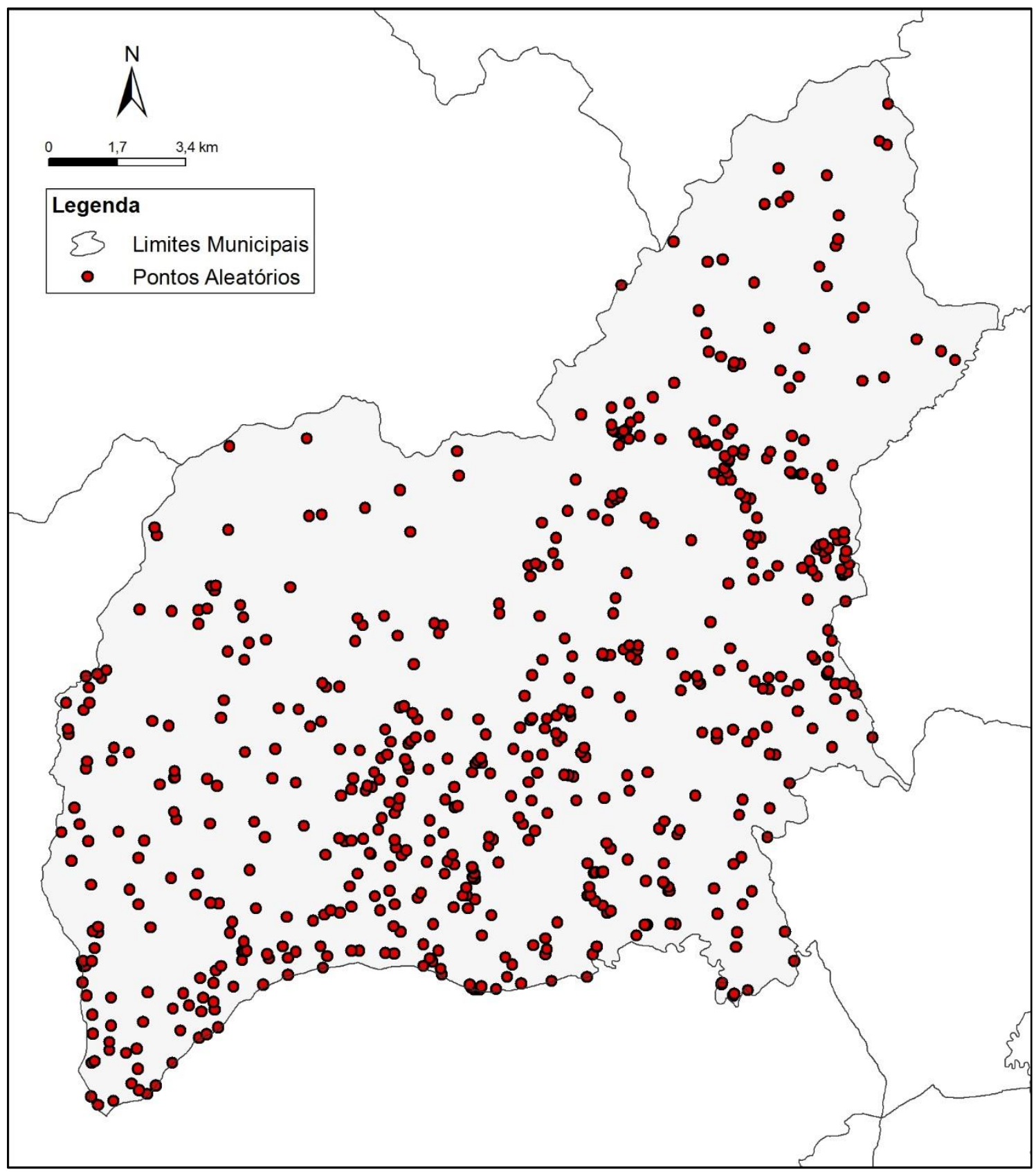

Figura 6.1 - Pontos de verdade de campo.

Com a tabela contendo os valores de verdade de campo e os valores obtidos do mapa foi gerada a matriz de confusão, que é apresentada na Tabela 6.1 , a seguir. 


\begin{tabular}{|c|c|c|c|c|c|c|c|c|c|c|c|c|c|}
\hline & \multicolumn{13}{|c|}{ Verificação com pontos de campo e ortofotografias de altíssima resolução espacial } \\
\hline & \# & 1 & 2 & 3 & 4 & 5 & 6 & 7 & 8 & 9 & 10 & 11 & 12 \\
\hline \multirow{12}{*}{ 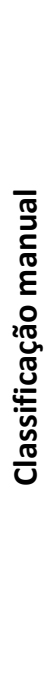 } & 1 & 50 & 0 & 0 & 0 & 0 & 0 & 0 & 0 & 0 & 0 & 0 & 0 \\
\hline & 2 & 0 & 50 & 0 & 0 & 0 & 0 & 0 & 0 & 0 & 0 & 0 & 0 \\
\hline & 3 & 1 & 0 & 43 & 0 & 0 & 4 & 2 & 0 & 0 & 0 & 0 & 0 \\
\hline & 4 & 7 & 1 & 0 & 38 & 4 & 0 & 0 & 0 & 0 & 0 & 0 & 0 \\
\hline & 5 & 0 & 0 & 0 & 0 & 52 & 0 & 0 & 0 & 0 & 0 & 0 & 0 \\
\hline & 6 & 0 & 0 & 0 & 0 & 0 & 50 & 0 & 0 & 0 & 0 & 0 & 0 \\
\hline & 7 & 0 & 1 & 0 & 0 & 1 & 2 & 46 & 0 & 0 & 0 & 0 & 0 \\
\hline & 8 & 1 & 0 & 0 & 0 & 0 & 1 & 2 & 45 & 1 & 0 & 0 & 0 \\
\hline & 9 & 0 & 0 & 0 & 0 & 0 & 0 & 1 & 2 & 47 & 0 & 0 & 0 \\
\hline & 10 & 1 & 0 & 0 & 0 & 0 & 0 & 0 & 0 & 0 & 49 & 0 & 0 \\
\hline & 11 & 0 & 0 & 0 & 0 & 0 & 0 & 1 & 0 & 0 & 0 & 49 & 0 \\
\hline & 12 & 0 & 0 & 0 & 0 & 0 & 0 & 0 & 0 & 0 & 0 & 0 & 50 \\
\hline
\end{tabular}

Classes: 1 - Urbano Regular; 2 - Urbano Irregular; 3 - Urbano Rural ; 4 - Loteamento Desocupado; 5 Industria/ Galpao; 6 - Mata; 7 - Campo / Capoeira; 8 - Agricultura; 9 - Corpo D'água; 10 - Rodovias; 11 Mineração; 12 - Aeroporto;

Tabela 6.1 - Matriz de confusão

A partir desses valores foi possível calcular o índice Kappa par ao mapeamento em questão. O índice calculado é apresentado na tabela 6.2, a seguir.

Correlação observada: $94,52 \%$
Quantidade de erros: $8,34 \%$
Índice Kappa: $94,02 \%$

Tabela 6.2 - Índice Kappa observado

O cálculo do índice Kappa resultou em acurácia de 94\%, o que indica alta qualidade do mapeamento, de acordo com Landis e Koch (1977). É importante destacar que o resultado elevado é esperado para mapeamentos realizados manualmente, principalmente pela constante interação entre o especialista e as imagens utilizadas na classificação.

E conforme detalhado anteriormente, não foi possível a verificação da qualidade dos mapeamentos dos anos anteriores por meio do índice Kappa, porque não há imagens ortorretificadas com melhor resolução espacial para o período e tampouco informações de campo. 


\subsection{Mapeamentos}

A Tabela 6.3, a seguir, apresenta as áreas e proporção de cada classe de cobertura e uso nos anos de 1986,1993, 2000 e 2007 referentes ao município de Guarulhos. Conforme elucidado anteriormente, foram utilizadas 12 classes sendo importante o exercício de comparação em cada ano para se verificar as alterações relativas de cobertura e uso da terra.

\begin{tabular}{|c|l|c|c|c|c|c|c|c|c|}
\hline Cód & \multicolumn{2}{|c|}{ Classe } & \multicolumn{2}{c|}{1986} & \multicolumn{2}{c|}{1993} & \multicolumn{2}{c|}{$\mathbf{2 0 0 0}$} & \multicolumn{2}{c|}{2007} \\
\hline 1 & Urbano Regular & 42,96 & $13,5 \%$ & 58,29 & $18,3 \%$ & 67,69 & $21,2 \%$ & 70,82 & $22,2 \%$ \\
\hline 2 & Urbano Irregular & 0,39 & $0,1 \%$ & 1,57 & $0,5 \%$ & 1,95 & $0,6 \%$ & 1,97 & $0,6 \%$ \\
\hline 3 & Urbano Rural & 1,96 & $0,6 \%$ & 3,61 & $1,1 \%$ & 3,80 & $1,2 \%$ & 3,80 & $1,2 \%$ \\
\hline 4 & Loteamento Desocupado & 40,63 & $12,8 \%$ & 29,59 & $9,3 \%$ & 19,13 & $6,0 \%$ & 14,78 & $4,6 \%$ \\
\hline 5 & Indústria / Galpão & 5,53 & $1,7 \%$ & 17,78 & $5,6 \%$ & 20,13 & $6,3 \%$ & 22,33 & $7,0 \%$ \\
\hline 6 & Mata & 127,17 & $39,9 \%$ & 125,84 & $39,5 \%$ & 125,37 & $39,4 \%$ & 125,10 & $39,3 \%$ \\
\hline 7 & Campo / Capoeira & 80,2 & $25,2 \%$ & 60,11 & $18,9 \%$ & 58,98 & $18,5 \%$ & 58,04 & $18,2 \%$ \\
\hline 8 & Agricultura & 3,68 & $1,2 \%$ & 5,05 & $1,6 \%$ & 4,79 & $1,5 \%$ & 4,70 & $1,5 \%$ \\
\hline 9 & Corpo d'Água & 2,02 & $0,6 \%$ & 2,10 & $0,7 \%$ & 2,10 & $0,7 \%$ & 2,10 & $0,7 \%$ \\
\hline 10 & Rodovias & 2,27 & $0,7 \%$ & 2,27 & $0,7 \%$ & 2,27 & $0,7 \%$ & 2,27 & $0,7 \%$ \\
\hline 11 & Mineração & 2,11 & $0,7 \%$ & 2,70 & $0,8 \%$ & 2,70 & $0,8 \%$ & 3,01 & $0,9 \%$ \\
\hline 12 & Aeroporto & 9,70 & $3,0 \%$ & 9,70 & $3,0 \%$ & 9,70 & $3,0 \%$ & 9,70 & $3,0 \%$ \\
\hline \multicolumn{2}{r}{ Total } & 318,6 & $100 \%$ & 318,6 & $100 \%$ & 318,6 & $100 \%$ & 318,6 & $100 \%$ \\
\hline
\end{tabular}

Tabela 6.3 - Áreas e respectivas proporções dos mapas de cobertura e uso da terra para os anos de 1986, 1993, 2000 e 2007 do município de Guarulhos.

Os mapas de cobertura e uso da terra para os anos 1986, 1993, $2000 \mathrm{e}$ 2007 são apresentados nas Figuras 6.2, 6.3, 6.4 e 6.5 a seguir, onde é possível verificar o mosaico de classes na paisagem. No quadro de legendas à direita de cada mapa, também estão apresentadas as transições das classes de Urbano Regular, Urbano Irregular e Indústria /Galpão, mostrando em preto as áreas existentes no mapa anterior, e em vermelho, as áreas que passaram a compor tais classes no ano em questão. 


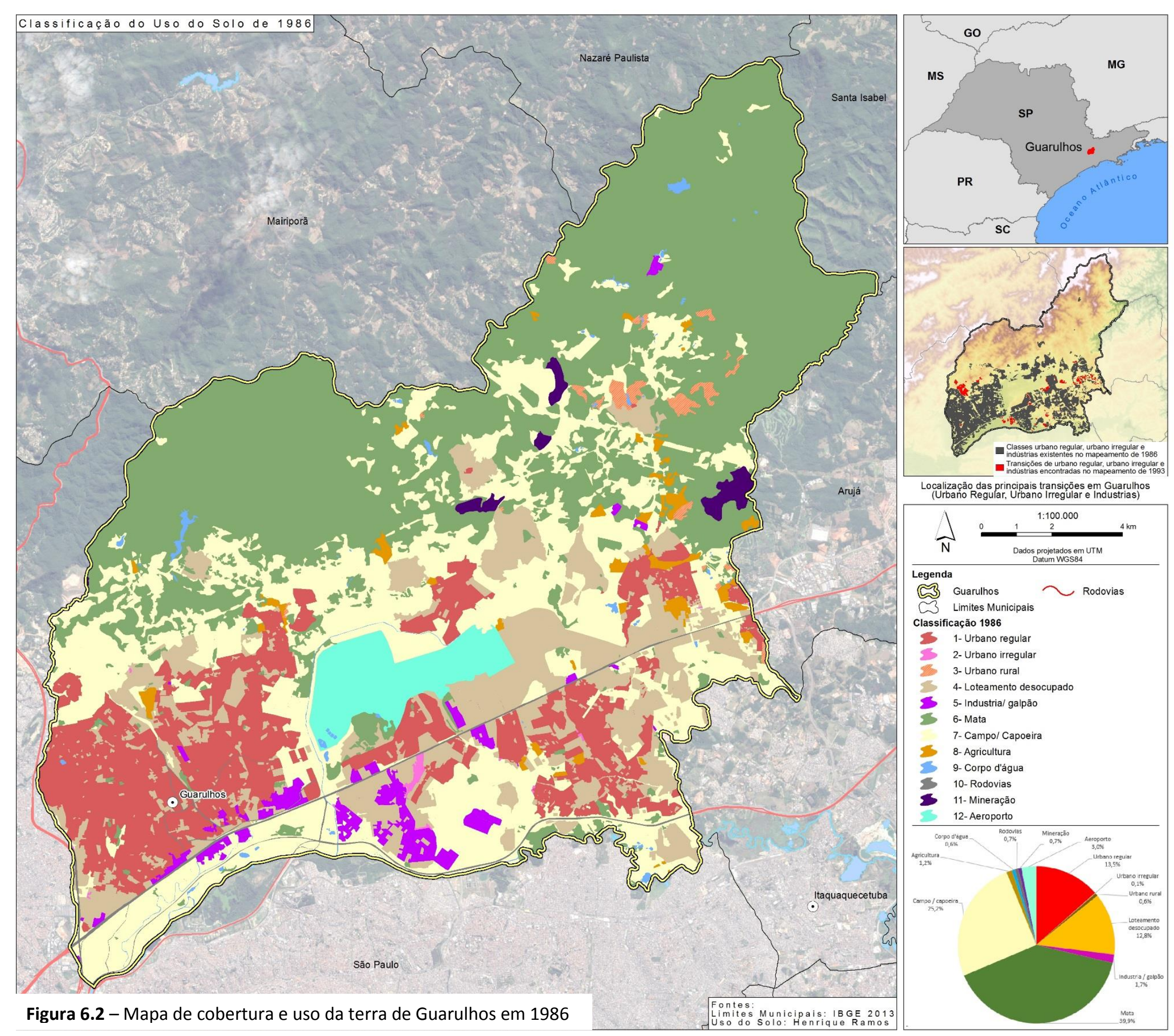




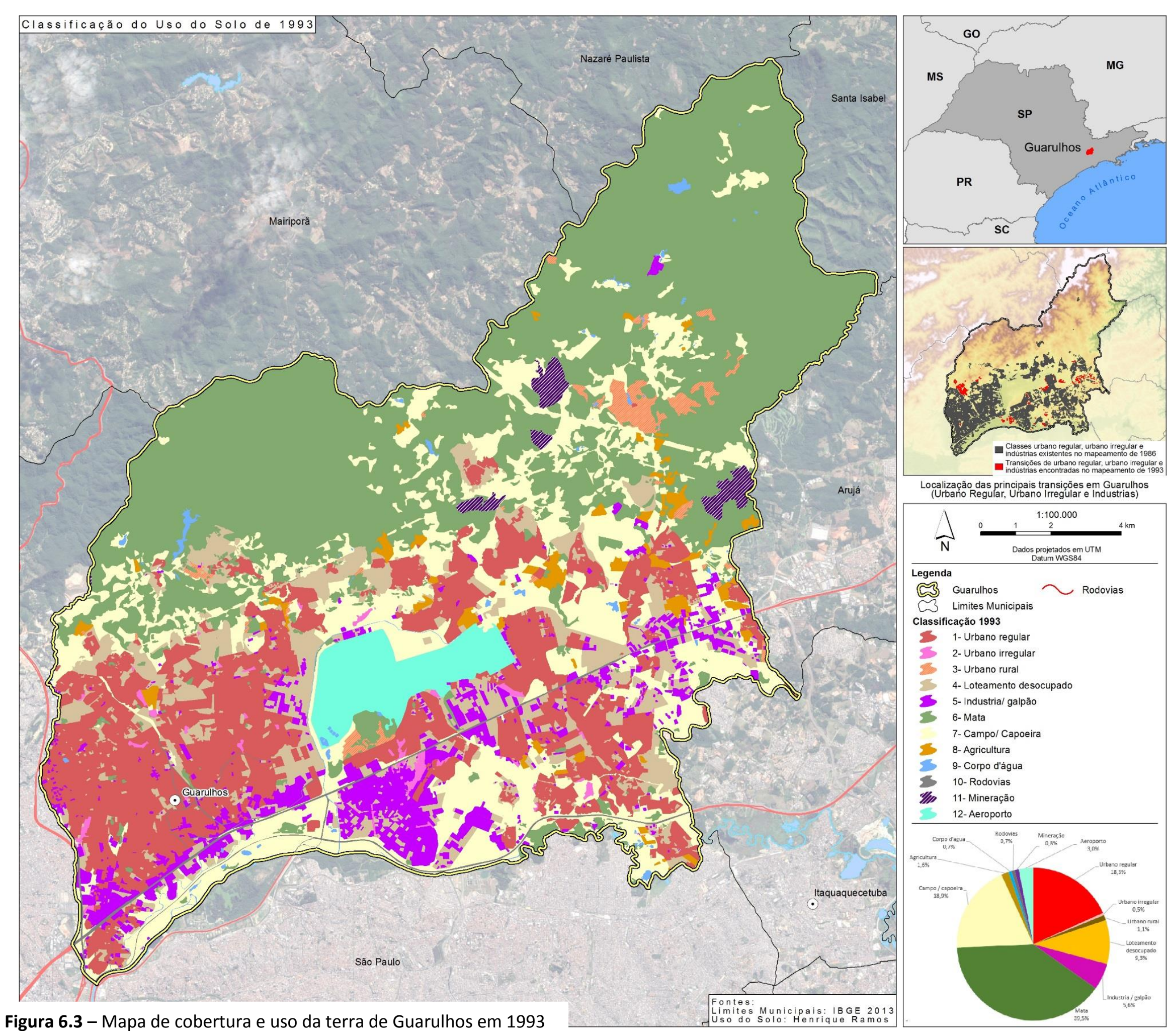



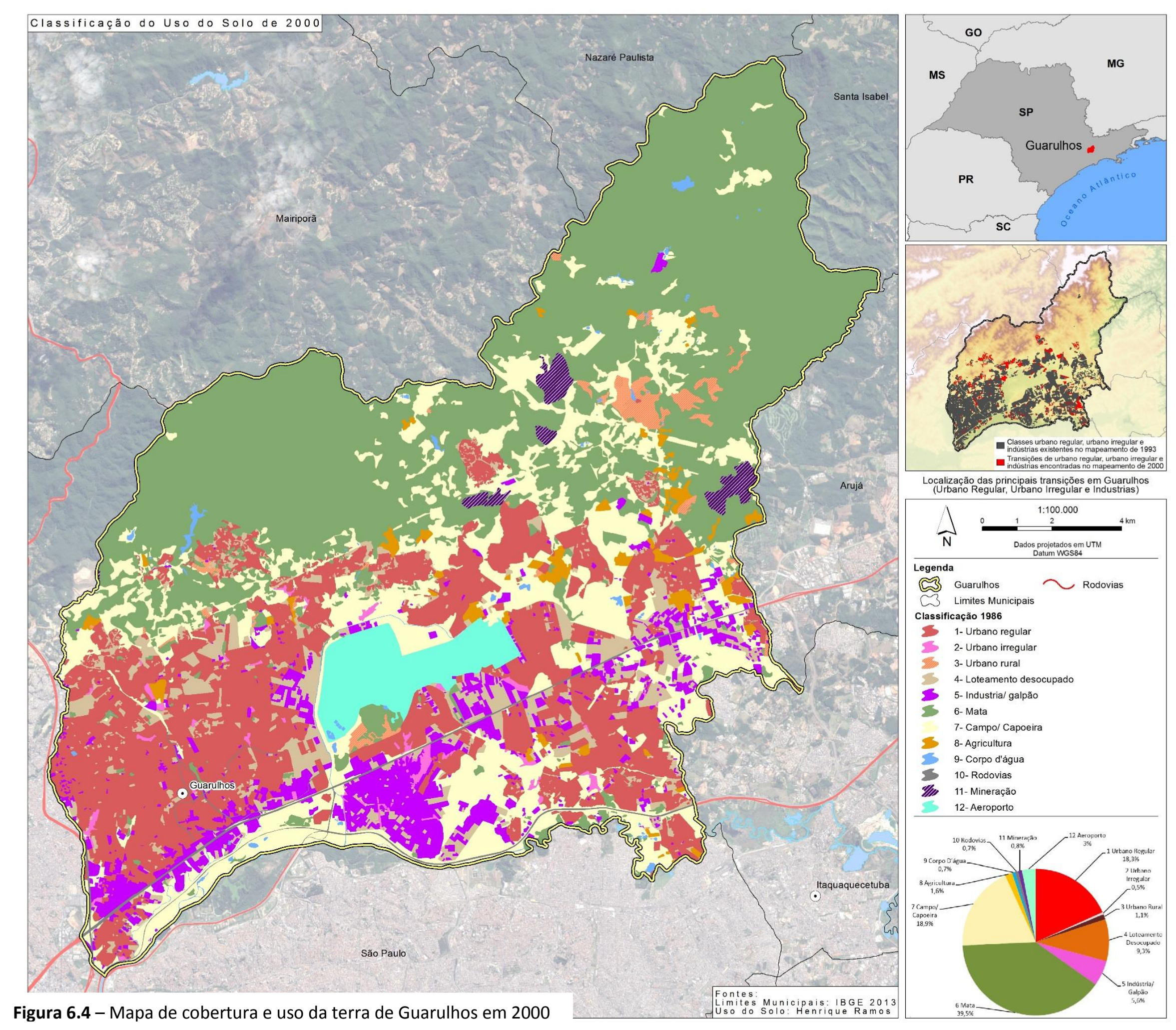


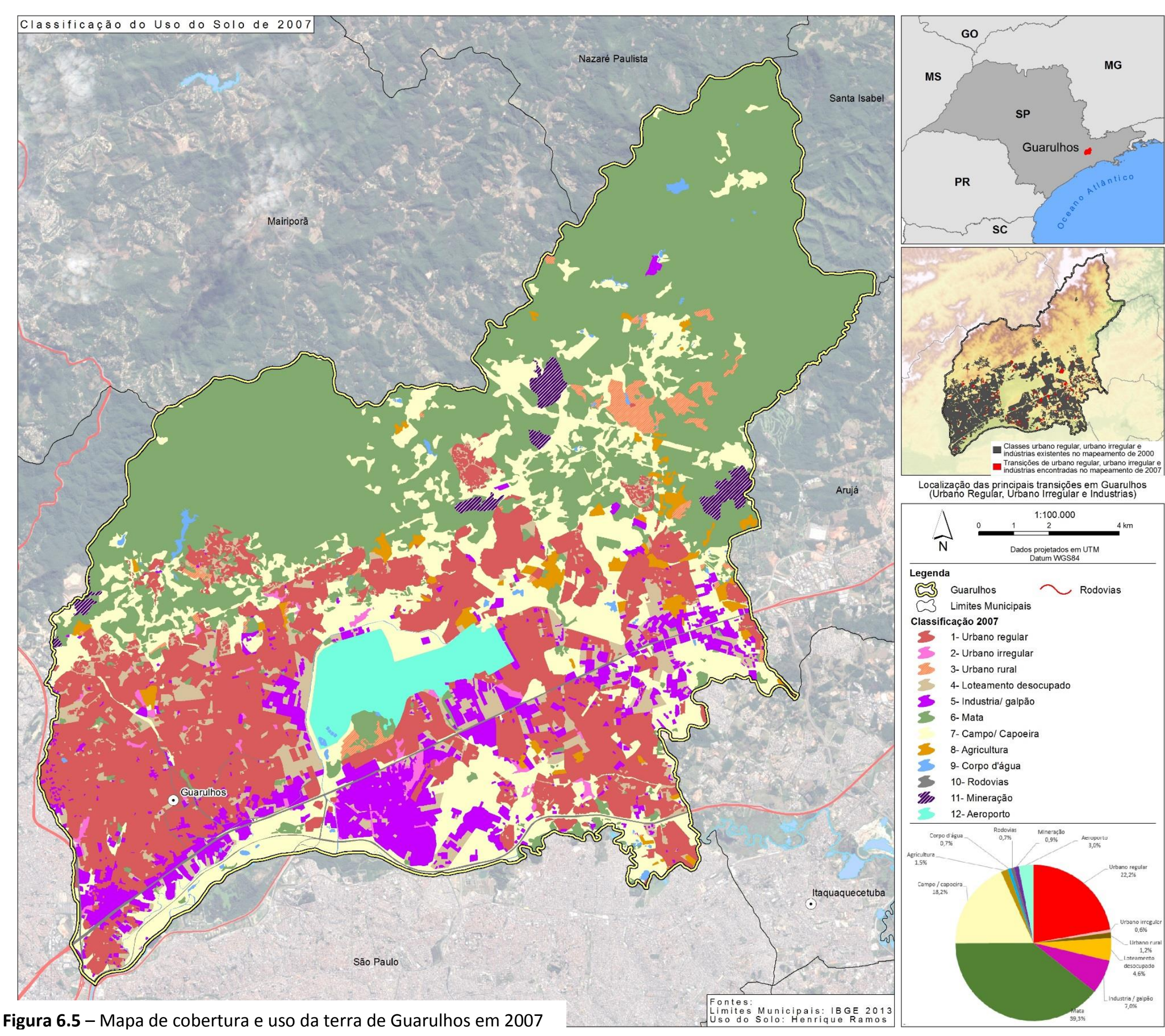




\subsection{Matrizes de Transição}

As matrizes de transição de passo simples foram obtidas por meio do Dinamica-EGO, como resultado do cruzamento entre os mapas matriciais de cobertura e uso da terra para o tempo inicial $\left(T_{0}\right)$ e tempo final $\left(T_{1}\right)$ de cada período analisado, e quantificam as transições totais ocorridas em cada um dos períodos.

\subsubsection{Matriz de Transição para o Período entre 1986 e 1993}

$\mathrm{Na}$ Tabela 6.4 estão apresentadas as porcentagens de mudanças relativas a este período no qual foram computadas um total de 23 transições.

\begin{tabular}{|l|c|c|c|c|c|c|c|c|c|}
\hline \multicolumn{1}{|c|}{ De / Para } & $\begin{array}{c}\text { Urbano } \\
\text { Regular }\end{array}$ & $\begin{array}{c}\text { Urbano } \\
\text { Irregular }\end{array}$ & $\begin{array}{c}\text { Urbano } \\
\text { Rural }\end{array}$ & $\begin{array}{c}\text { Loteamento } \\
\text { Desocupado }\end{array}$ & $\begin{array}{c}\text { Indústria } \\
\text { / Galpão }\end{array}$ & $\begin{array}{c}\text { Campo / } \\
\text { Capoeira }\end{array}$ & Agricultura & $\begin{array}{c}\text { Corpo } \\
\text { d'Água }\end{array}$ & Mineração \\
\hline $\begin{array}{l}\text { Urbano } \\
\text { Regular }\end{array}$ & - & - & - & - & $0,45 \%$ & - & - & - & - \\
\hline $\begin{array}{l}\text { Loteamento } \\
\text { Desocupado }\end{array}$ & $27,54 \%$ & $2,27 \%$ & $3,68 \%$ & - & $23,84 \%$ & - & - & - & - \\
\hline $\begin{array}{l}\text { Indústria / } \\
\text { Galpão }\end{array}$ & - & - & - & $6,83 \%$ & - & $0,16 \%$ & - & - & - \\
\hline Mata & - & - & - & $0,48 \%$ & $0,02 \%$ & $0,38 \%$ & $0,05 \%$ & - & - \\
\hline $\begin{array}{l}\text { Campo / } \\
\text { Capoeira }\end{array}$ & $5,17 \%$ & $0,29 \%$ & $0,19 \%$ & $14,56 \%$ & $3,43 \%$ & - & $1,74 \%$ & $0,10 \%$ & $0,74 \%$ \\
\hline Agricultura & $0,82 \%$ & $0,74 \%$ & - & - & - & $0,93 \%$ & - & - & - \\
\hline
\end{tabular}

Tabela 6.4 - Matriz de transição de passo simples para o período entre 1986 e 1993.

Como pode ser observado na Tabela 6.4, as maiores contribuições para a formação das áreas ocupadas por novas classes vieram dos loteamentos desocupados em 1986, sendo mais evidentes nas transições para a classe Urbano Regular e Indústria/ Galpão, que no período corresponderam a 27,54\% e $23,84 \%$, respectivamente.

Parte das áreas ocupadas por agricultura em 1986 deram lugar a áreas de uso Urbano Regular (0,82\%), Urbano Irregular (0,74\%) e Campo / Capoeira $(0,93 \%)$. Também no caso da redução das matas do município, que diminuiu pouco menos que $2 \mathrm{~km}^{2}$ no período entre 1986 e 1993, é possível verificar que as maiores pressões foram oriundas da abertura de novos campos / capoeiras e dos novos loteamentos. 
Também foram gerados os mapas de transições de classe para quantificar os parâmetros iniciais da modelagem. Os mapas que visualmente apresentaram as transições mais significativas foram os de Loteamento Desocupado para Urbano Regular, Loteamento Desocupado para Industrial, e Campo/Capoeira para Urbano Regular. Estes três mapas estão apresentados nas Figuras 6.6, 6.7 e 6.8.

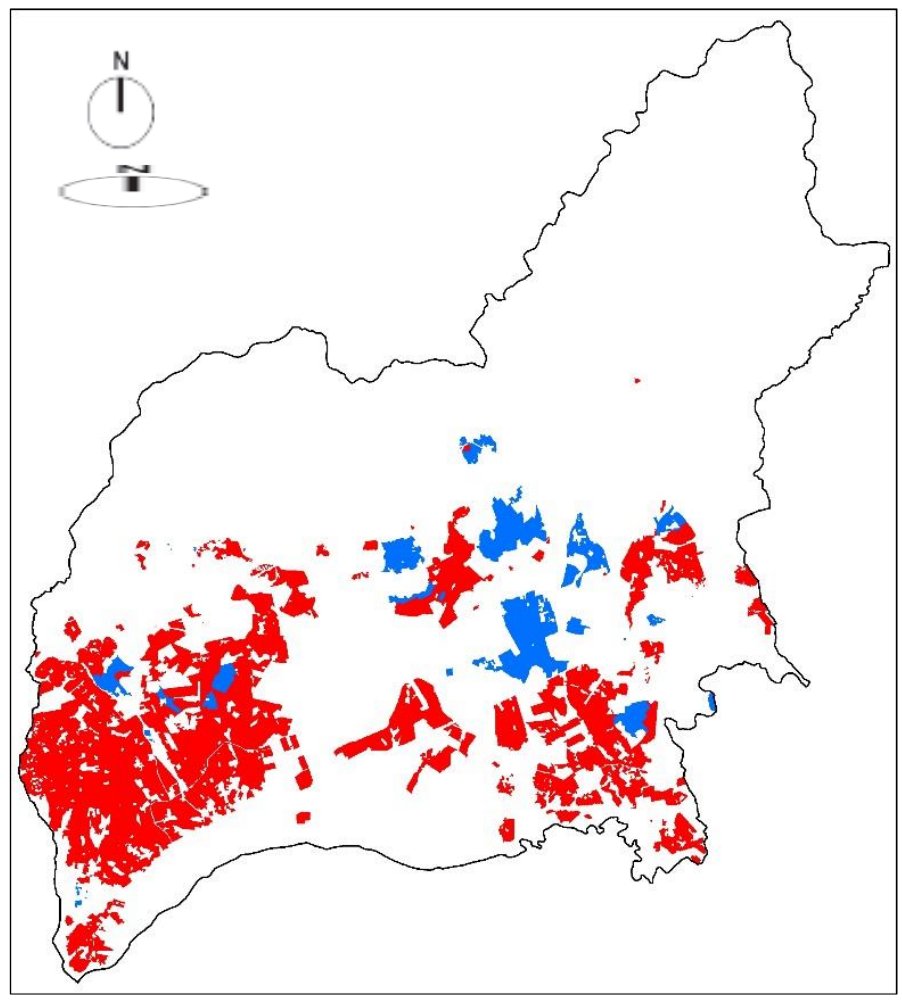

Figura 6.6 - Mapa de transição de classe, de Loteamento Desocupado para Urbano Regular. (Em vermelho estão as áreas classificadas como Urbano Regular em 1986, e em azul estão as áreas de Loteamento Desocupado que transitaram para Urbano Regular em 1993) 


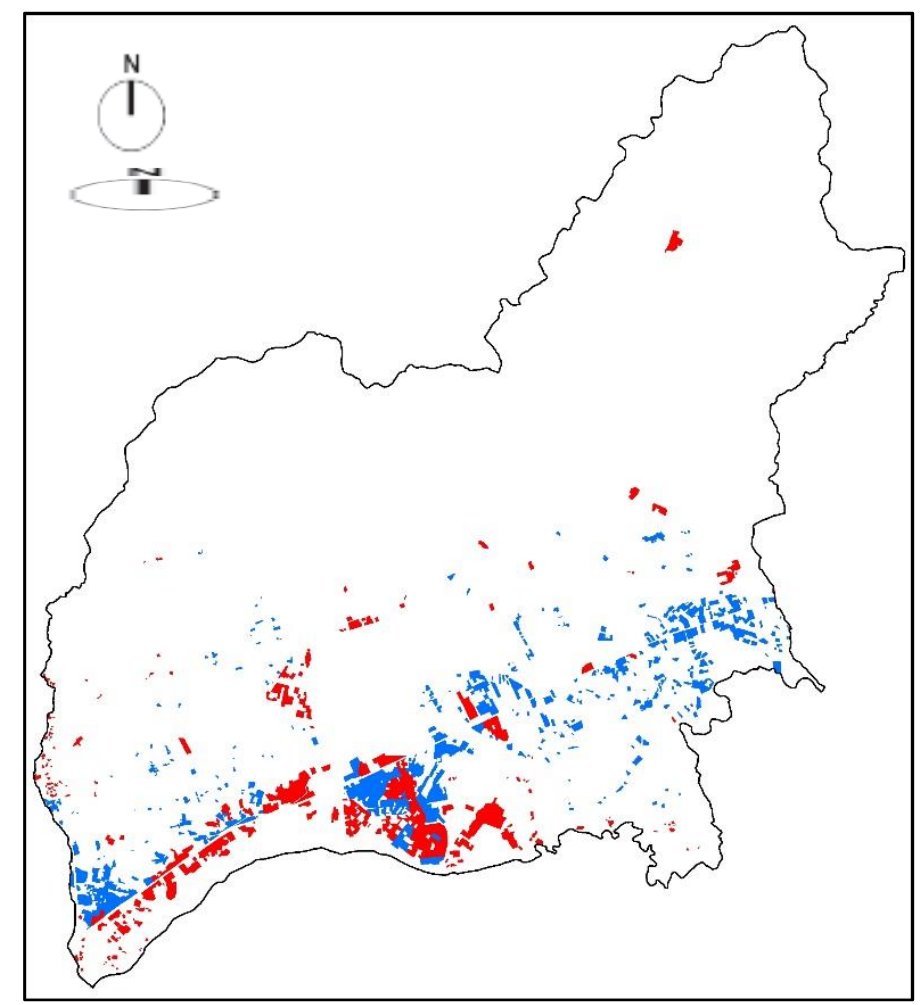

Figura 6.7 - Mapa de transição de classe, de Loteamento Desocupado para Indústria. (Em vermelho estão as áreas classificadas como Indústria/ Galpão em 1986, e em azul estão as áreas de Loteamento Desocupado que transitaram para Indústria/ Galpão em 1993)

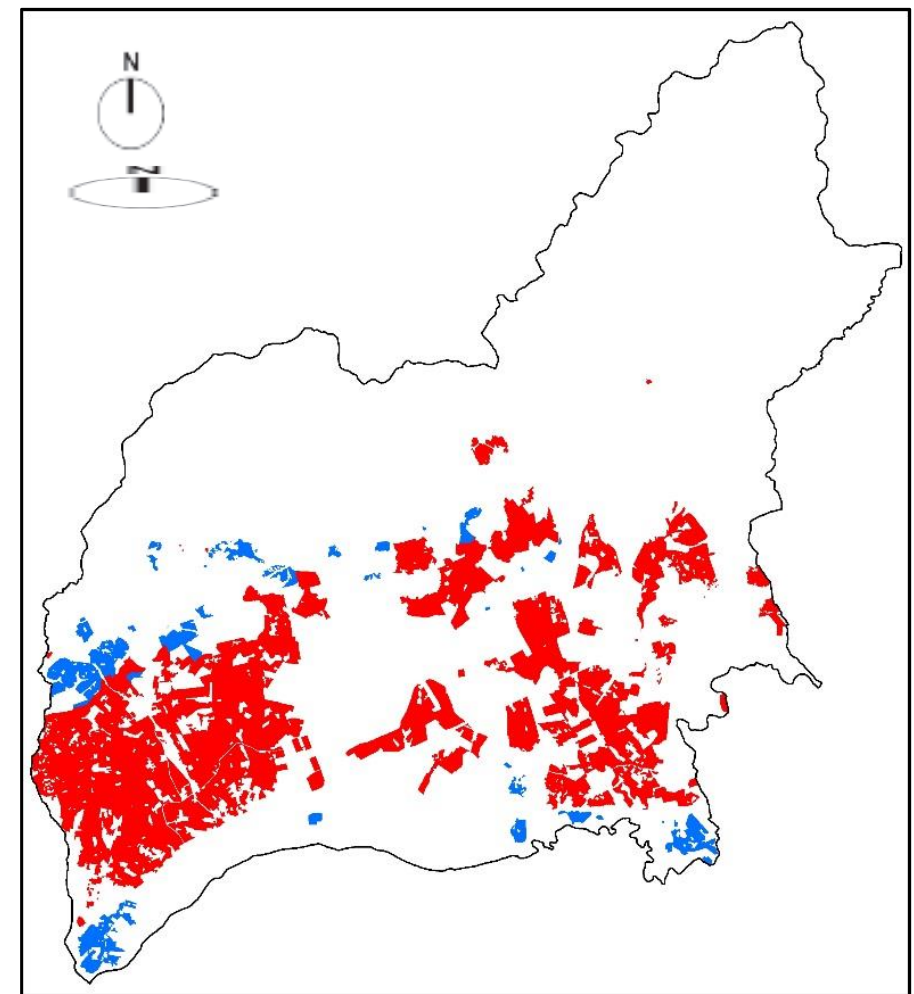

Figura 6.8 - Mapa de transição de classe, de Campo/ Capoeira para Urbano Regular. (Em vermelho estão as áreas classificadas como Urbano Regular em 1986, e em azul estão as áreas de Campo/ Capoeira que transitaram para Urbano Regular em 1993) 


\subsubsection{Matriz de Transição para o Período entre 1993 e 2000}

$\mathrm{Na}$ Tabela 6.5, estão apresentadas as porcentagens de mudanças relativas a este período, no qual foi computado um total de 21 transições.

\begin{tabular}{|l|c|c|c|c|c|c|c|}
\hline \multicolumn{1}{|c|}{ De / Para } & $\begin{array}{c}\text { Urbano } \\
\text { Regular }\end{array}$ & $\begin{array}{c}\text { Urbano } \\
\text { Irregular }\end{array}$ & $\begin{array}{c}\text { Urbano } \\
\text { Rural }\end{array}$ & $\begin{array}{c}\text { Loteamento } \\
\text { Desocupado }\end{array}$ & $\begin{array}{c}\text { Indústria / } \\
\text { Galpão }\end{array}$ & $\begin{array}{c}\text { Campo / } \\
\text { Capoeira }\end{array}$ & Agricultura \\
\hline Urbano Regular & - & - & - & - & $0,01 \%$ & - & - \\
\hline $\begin{array}{l}\text { Loteamento } \\
\text { Desocupado }\end{array}$ & $28,61 \%$ & $0,24 \%$ & $0,12 \%$ & - & $7,21 \%$ & $0,09 \%$ & - \\
\hline Indústria / Galpão & $0,33 \%$ & $0,21 \%$ & - & - & - & - & - \\
\hline Mata & $0,10 \%$ & - & $0,09 \%$ & $0,03 \%$ & - & $0,16 \%$ & - \\
\hline Campo / Capoeira & $1,26 \%$ & $0,45 \%$ & $0,07 \%$ & $0,35 \%$ & $0,48 \%$ & - & $0,06 \%$ \\
\hline Agricultura & $0,06 \%$ & - & - & $0,96 \%$ & - & $4,74 \%$ & - \\
\hline
\end{tabular}

Tabela 6.5- Matriz de transição de passo simples para o período entre 1993 e 2000.

Como pode ser observado nesta tabela, as maiores contribuições para a formação das áreas ocupadas por novas classes vieram dos loteamentos desocupados em 1993, sendo mais evidentes nas transições para as classes Urbano Regular e Indústria/ Galpão, que no período corresponderam a 28,6\% e $7,21 \%$, respectivamente.

Da mesma forma que ocorreu no período anterior, entre 1985 e 1993, a Tabela 6.4 aponta para a conversão de áreas industriais para as classes Urbano Regular e Urbano Irregular, com taxas de 0,33\% e 0,21\% respectivamente.

A maior parte das áreas de agricultura que sofreram alteração a partir de 1993 foram convertidas em Campo / Capoeira (4,74\%). No caso da redução das matas do município neste período, verifica-se que as maiores pressões foram oriundas da abertura de áreas de Campo / Capoeira, dos novos loteamentos e da formação de novas áreas ocupadas pela classe Urbano Rural.

Além disso, também foram criados os mapas de transição de classes para quantificar os parâmetros iniciais da modelagem. Visualmente, os mapas com as transições mais significativas foram de Loteamento Desocupado para Urbano Regular, Loteamento Desocupado para Indústria / Galpão, e Campo / Capoeira para Urbano Regular. Estes três mapas estão apresentados nas Figuras 6.9, 6.10 e 6.11 . 


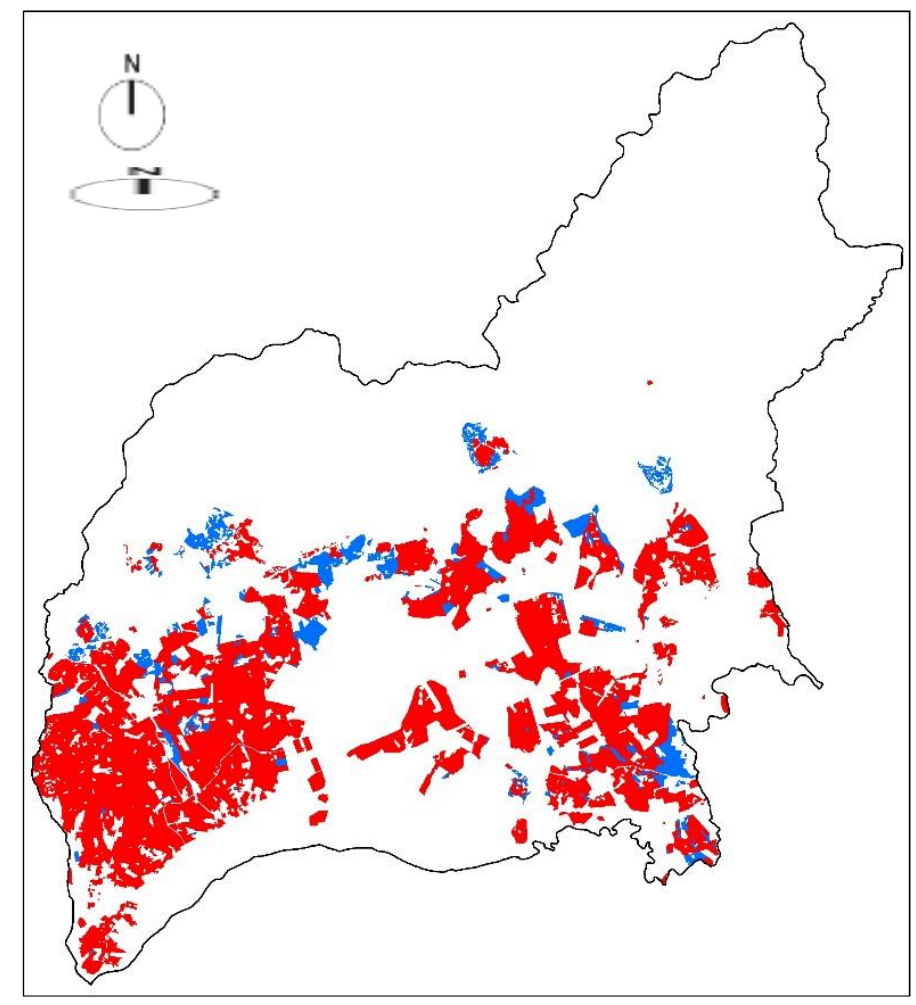

Figura 6.9 - Mapa de transição de classe, de Loteamento Desocupado para Urbano Regular. (Em vermelho estão as áreas classificadas como Urbano Regular em 1993, e em azul estão as áreas de Loteamento Desocupado que transitaram para Urbano Regular em 2000)

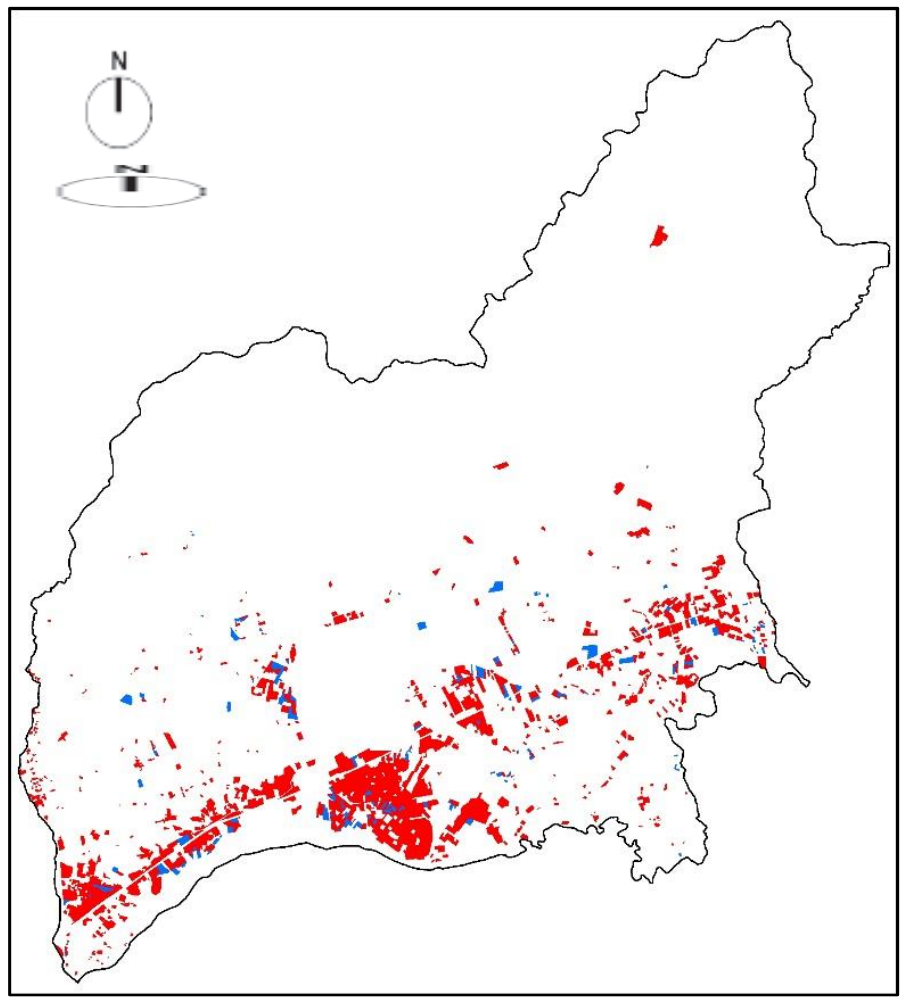

Figura 6.10 - Mapa de transição de classe, de Loteamento Desocupado para Indústria. (Em vermelho estão as áreas classificadas como Industria/ Galpão em 1993, e em azul estão as áreas de Loteamento Desocupado que transitaram para Indústria/ Galpão em 2000) 


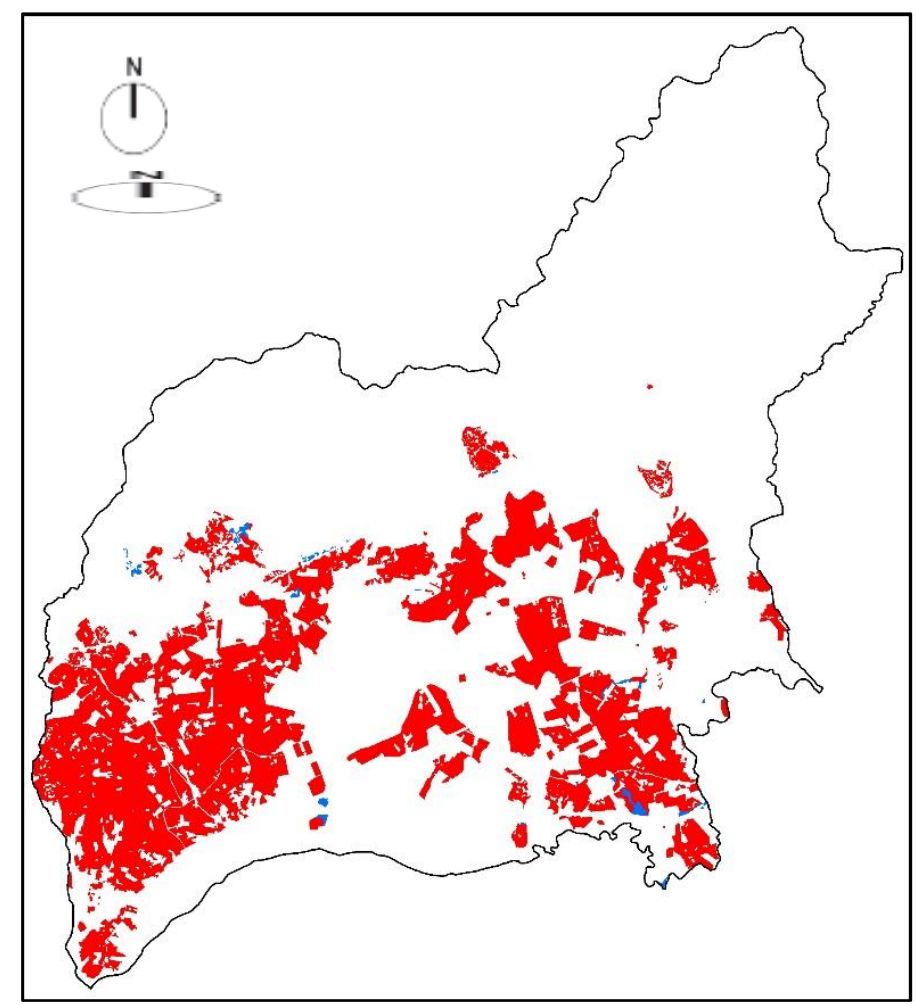

Figura 6.11 - Mapa de transição de classe, de Campo/ Capoeira para Urbano Regular. (Em vermelho estão as áreas classificadas como Urbano Regular em 1993, e em azul estão as áreas de Campo/ Capoeira que transitaram para Urbano Regular em 2000)

\subsubsection{Matriz de Transição para o Período entre 2000 e 2007}

$\mathrm{Na}$ Tabela 6.6, estão apresentadas as porcentagens de mudanças relativas a este período, no qual foi computado um total de 19 transições.

\begin{tabular}{|l|c|c|c|c|c|c|c|c|}
\hline \multicolumn{1}{|c|}{ De / Para } & $\begin{array}{c}\text { Urbano } \\
\text { Regular }\end{array}$ & $\begin{array}{c}\text { Urbano } \\
\text { Irregular }\end{array}$ & $\begin{array}{c}\text { Urbano } \\
\text { Rural }\end{array}$ & $\begin{array}{c}\text { Loteamento } \\
\text { Desocupado }\end{array}$ & $\begin{array}{c}\text { Indústria } \\
\text { / Galpão }\end{array}$ & $\begin{array}{c}\text { Campo / } \\
\text { Capoeira }\end{array}$ & Agricultura & Mineração \\
\hline Urbano Irregular & $0,27 \%$ & - & - & $1,65 \%$ & - & - & - & - \\
\hline $\begin{array}{l}\text { Loteamento } \\
\text { Desocupado }\end{array}$ & $12 \%$ & $0,07 \%$ & - & - & $11,26 \%$ & - & - & - \\
\hline Indústria / Galpão & $0,46 \%$ & $0,38 \%$ & - & - & - & $0,02 \%$ & - & - \\
\hline Mata & $0,03 \%$ & - & - & - & $0,01 \%$ & $0,18 \%$ & - & - \\
\hline Campo / Capoeira & $1,04 \%$ & $0,08 \%$ & - & - & $0,31 \%$ & - & $0,06 \%$ & $0,52 \%$ \\
\hline Agricultura & $1,71 \%$ & - & - & - & $0,42 \%$ & $0,66 \%$ & - & - \\
\hline
\end{tabular}

Tabela 6.6 - Matriz de transição de passo simples para o período entre 2000 e 2007.

Como pode ser observado nesta tabela, as maiores contribuições para a formação das áreas ocupadas por novas classes vieram dos loteamentos desocupados em 2000, sendo mais evidentes nas transições para as classes 
Urbano Regular e Indústria/ Galpão, que no período corresponderam a 12\% e $11,26 \%$, respectivamente.

Da mesma forma que no período anterior, a Tabela 6.5 aponta para a conversão de áreas de Indústria / Galpão para as classes Urbano Regular e Urbano Irregular, com taxas de $0,46 \%$ e $0,38 \%$, respectivamente.

A maior parte das áreas de agricultura que sofreram alteração a partir de 1993 foram convertidas em Urbano Regular (1,71\%). No caso da redução das matas do município neste período, verifica-se que as maiores pressões foram oriundas da abertura de áreas de Campo / Capoeira, dos novos loteamentos e da formação de novas áreas ocupadas pela classe Urbano Rural.

Além disso, também foram criados os mapas para verificação das transições, a fim de se quantificar os parâmetros iniciais da modelagem. Visualmente, os mapas com as transições mais significativas foram de Loteamento Desocupado para Urbano Regular, Loteamento Desocupado para Indústria / Galpão, e Campo / Capoeira para Urbano Regular. Estes três mapas estão apresentados nas Figuras 6.12, 6.13 e 6.14 .

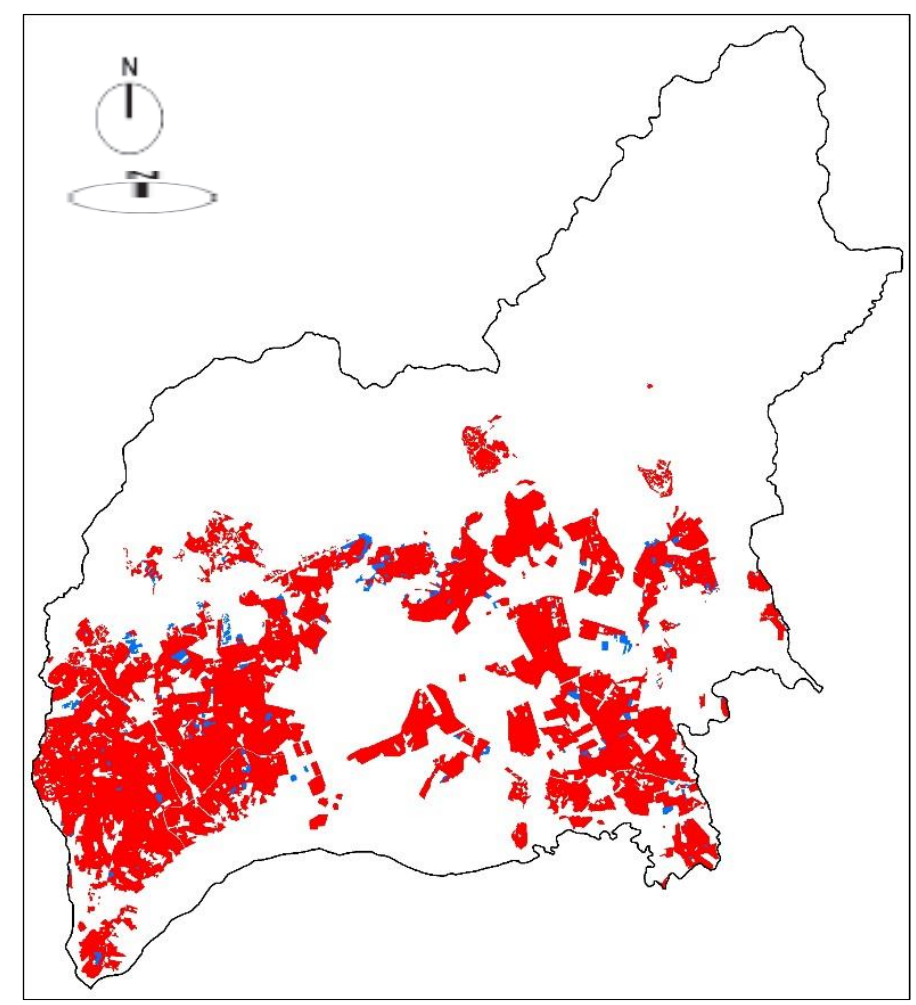

Figura 6.12 - Mapa de transição de classe, de Loteamento Desocupado para Urbano Regular. (Em vermelho estão as áreas classificadas em Urbano Regular em 2000, e em azul estão as áreas de Loteamento Desocupado que transitaram para Urbano Regular em 2007) 


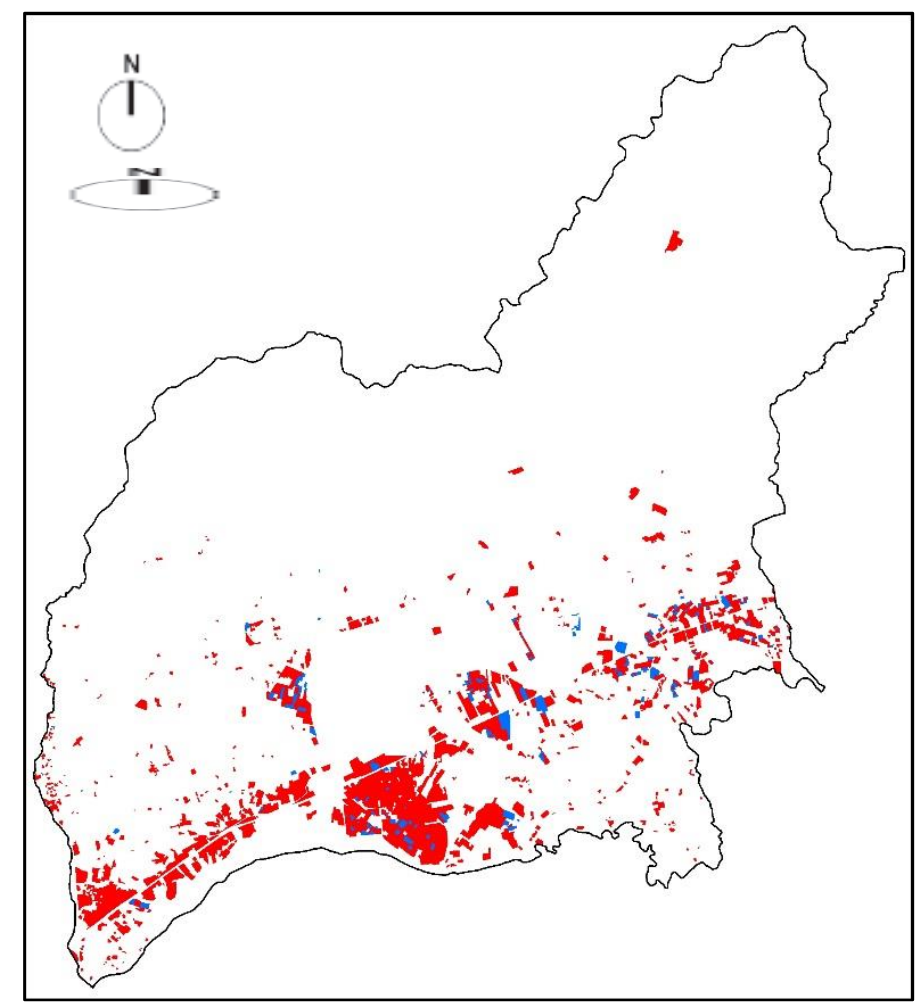

Figura 6.13 - Mapa de transição de classe, de Loteamento Desocupado para Indústria. (Em vermelho estão as áreas classificadas como Industria/ Galpão em 2000, e em azul estão as áreas de Loteamento Desocupado que transitaram para Indústria/ Galpão em 2007)

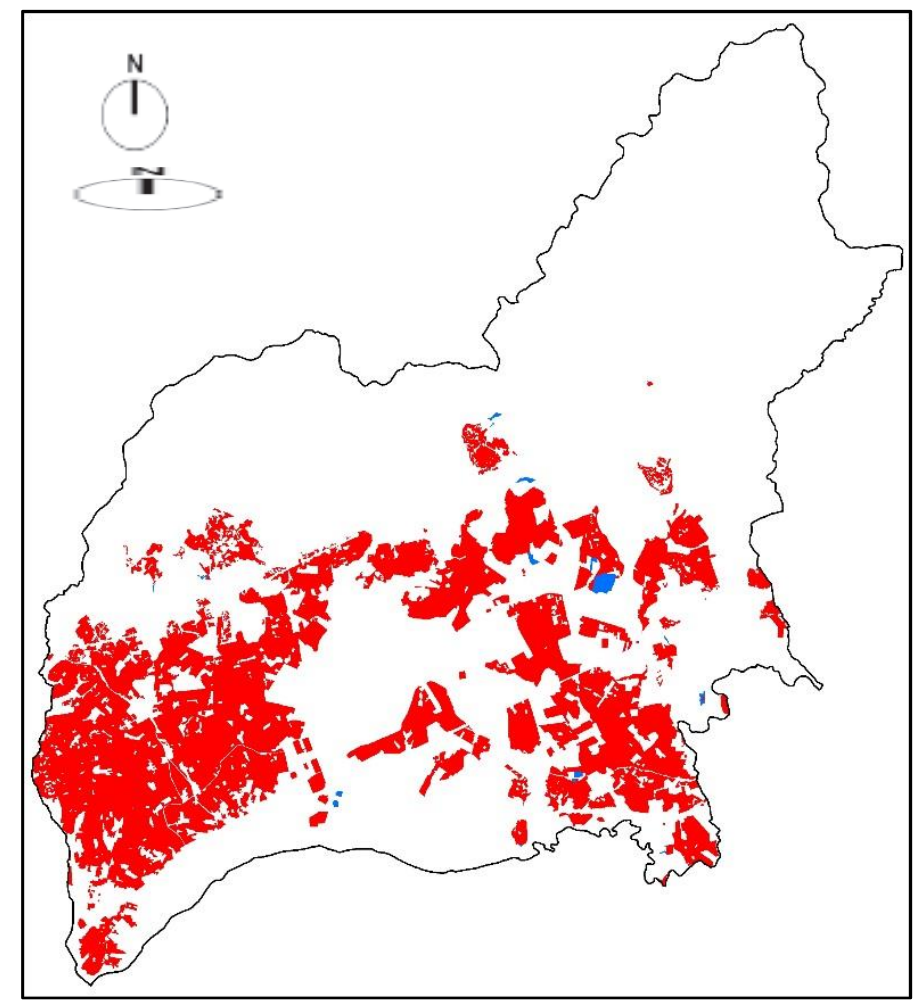

Figura 6.14 - Mapa de transição de classe, de Campo/ Capoeira para Urbano Regular. (Em vermelho estão as áreas classificadas em Urbano Regular em 2000, e em azul estão as áreas de Campo/ Capoeira que transitaram para Urbano Regular em 2007) 


\subsection{Pesos de Evidência}

Os pesos de evidência quantificam a influência exercida por um determinado elemento da paisagem, em função de sua proximidade, na probabilidade da transição de um estado da célula para outro. Com isso os pesos de evidência permitem avaliar como cada variável atuou na dinâmica da paisagem entre dois passos de tempo.

De forma geral, a interpretação dos pesos positivos de evidência se baseia no fato que os valores positivos se referem a uma associação positiva entre a variável e a transição analisada, enquanto os valores inferiores a zero indicam uma associação negativa entre elas. Com isso, é possível inferir de que forma a distância de dada variável afeta na alteração do estado de uma determinada célula.

Nas subseções a seguir, serão avaliados os resultados dos pesos de evidência para cada período, considerando-se as transições mais relevantes para a compreensão da dinâmica da paisagem no município de Guarulhos.

\subsubsection{Transição de Loteamento Desocupado para Urbano Regular}

$\mathrm{Na}$ transição de Loteamento Desocupado para Residencial Urbano, a distância aos logradouros exerce influência positiva até aproximadamente $50 \mathrm{~m}$ de distância, nos três períodos analisados.

Por sua vez, a distância às vias estruturais exerce uma influência diferente em cada período. Entre 1986 e 1993, a influência desta variável é pouco relevante até $1.600 \mathrm{~m}$ de distância, quando passa a oferecer influência negativa. No período seguinte, de 1993 a 2000, é possível verificar uma pequena influência positiva até $250 \mathrm{~m}$, passando a afetar negativamente as transições até $1.300 \mathrm{~m}$ de distância. A partir desse ponto, a influência passa a ser crescentemente positiva. No período final, entre 2000 e 2007, as transições se restringem a uma faixa menor ao redor destas vias estruturais, de modo que a influência é negativa apenas até $100 \mathrm{~m}$, quando então passa a apresentar valor de peso de evidência essencialmente positivo até $500 \mathrm{~m}$. Para além de $750 \mathrm{~m}$ de distância, já não há transições desse tipo. 
Em relação às vias macrometropolitanas, o período entre 1986 e 1993 mostrou que a proximidade com estas vias resultou em uma influência fortemente negativa nos primeiros $100 \mathrm{~m}$, de modo a diminuir tal influência aos poucos até os $750 \mathrm{~m}$ de distância. A partir daí e até a transição mais distante, a influência da variável é tipicamente positiva. Essa característica se repete nos dois períodos seguintes, mantendo a distância de $750 \mathrm{~m}$ como a transição entre a influência negativa para a positiva para esta transição, como pode ser verificado na Figura 6.15 a seguir

\begin{tabular}{|c|c|c|}
\hline \multicolumn{3}{|c|}{ Distância às vias macrometropolitanas } \\
\hline 1986-1993 & $1993-2000$ & $2000-2007$ \\
\hline 2.5 & 2.5 & \\
\hline${ }_{1.5}^{2} \ldots \ldots$ & $i_{1.5}^{2}$ & $\therefore$ \\
\hline $\mid \begin{array}{ll}1 & \ldots \\
0.5 & \ldots\end{array}$ & & 0.5 \\
\hline$c_{-0.5}^{1} \quad 750.5$ & $\int_{-0.5}^{b} \quad 750.5$ & 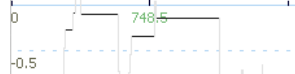 \\
\hline-1.5 & is & -1 \\
\hline
\end{tabular}

Figura 6.15 - Gráficos dos pesos de evidência com a variáveis de distância às Vias Macrometropolitanas.

A ocupação dos terrenos em função da declividade oferece um quadro sobre a ocupação do município de Guarulhos. Havendo maior diversidade de terrenos livres disponíveis neste período, a baixa declividade, com inclinação do terreno de até $8 \%$, ofereceu uma influência positiva, ao passo que nos períodos seguintes, quando se inicia com mais velocidade a ocupação de terrenos mais inclinados, a influência positiva passa a ocorrer nas declividades mais elevadas, acima de $7 \%$ nos dois períodos finais.

A distância às indústrias também fornece um quadro interessante para ser analisado em conjunto. Nos três períodos, há uma forte influência negativa à presença de indústria entre 300 e $500 \mathrm{~m}$, a partir de onde passa a exercer uma influência positiva com crescimento constante, conforme pode ser observado na Figura 6.16 abaixo.

\begin{tabular}{|c|c|c|}
\hline \multicolumn{3}{|c|}{ Distância às indústrias/galpões } \\
\hline 1986-1993 & $1993-2000$ & 2000-2007 \\
\hline 3 & & 3.75 \\
\hline & & $2.5^{\circ}$ \\
\hline$=-\frac{1}{1}$, & $\mid \begin{array}{lll}1 & \cdots & -\end{array}$ & 1.25 \\
\hline 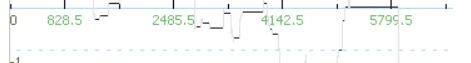 & 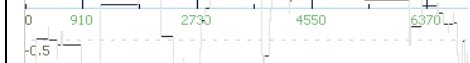 & $--^{-450}$ \\
\hline-7 & - & \\
\hline & & \\
\hline
\end{tabular}


Figura 6.16 - Gráficos dos pesos de evidência com a variável de Distância à Indústria /Galpão.

Por fim, a distância ao Aeroporto de Guarulhos também fornece um quadro interessante para análise em conjunto. No período entre 1986 e 1993, a proximidade com o aeroporto fornece influência positiva até $2.500 \mathrm{~m}$, quando então passa a exercer uma influência negativa crescente. Nos dois períodos seguintes, entre 1993 e 2000 e entre 2000 e 2007, a proximidade ao aeroporto exerceu uma influência negativa para o crescimento das áreas urbanas regulares. Essas características podem ser observadas na Figura 6.17 a seguir.

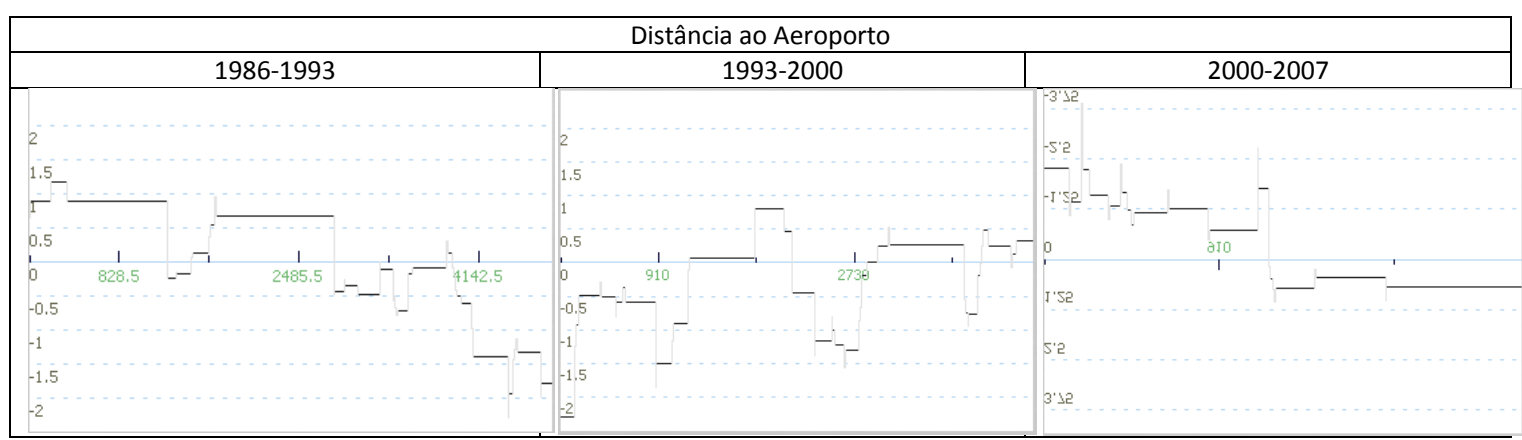

Figura 6.17 - Gráficos dos pesos positivos de evidência com a variável de Distância ao Aeroporto.

A seguir, são apresentados os mapas de probabilidade para esta transição nos três períodos analisados, nas Figuras 6.18, 6.19 e 6.20. 


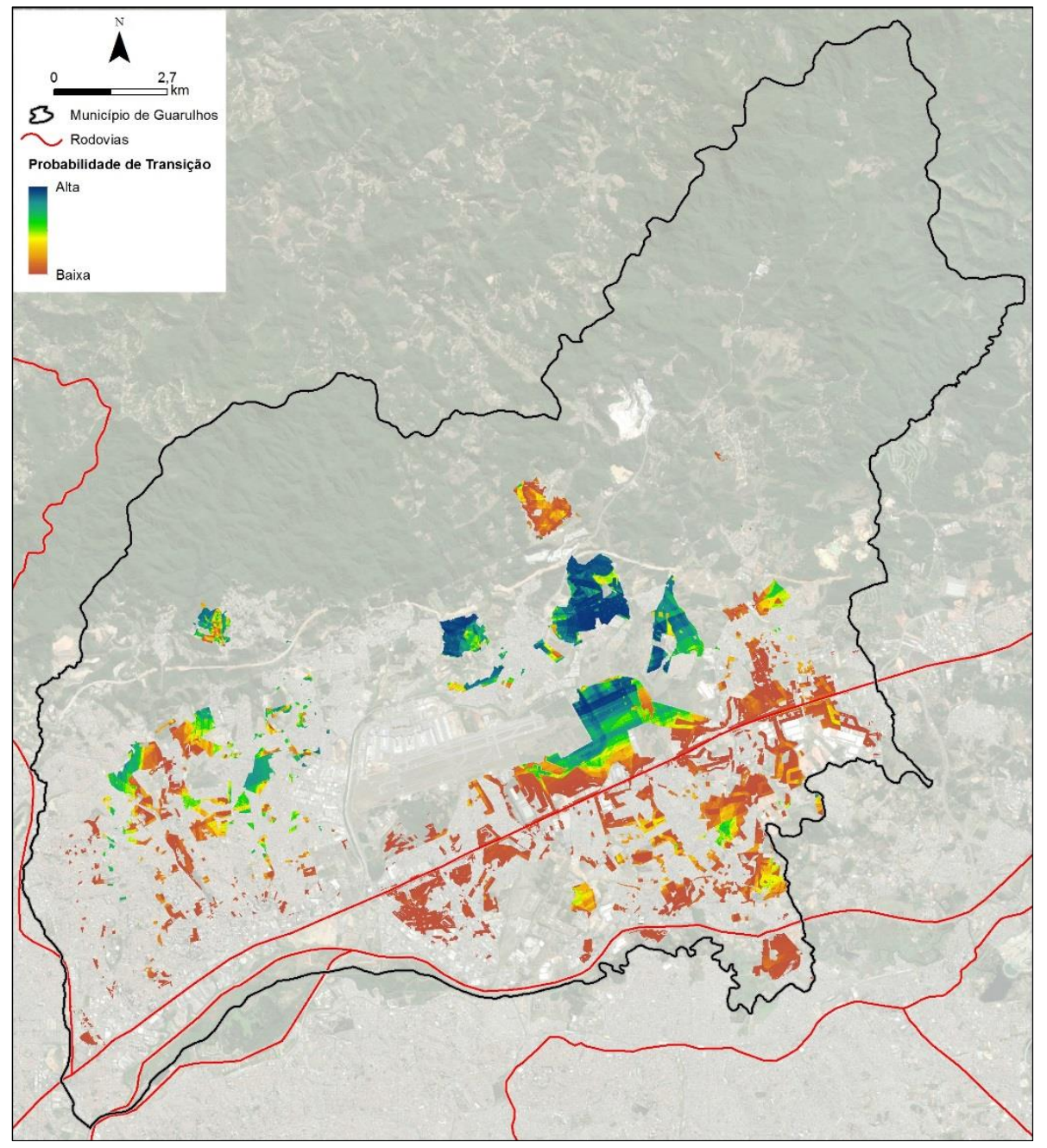

Figura 6.18 - Mapa de probabilidade de transição de Loteamento Desocupado para Urbano Regular no período entre 1986 e 1993. 


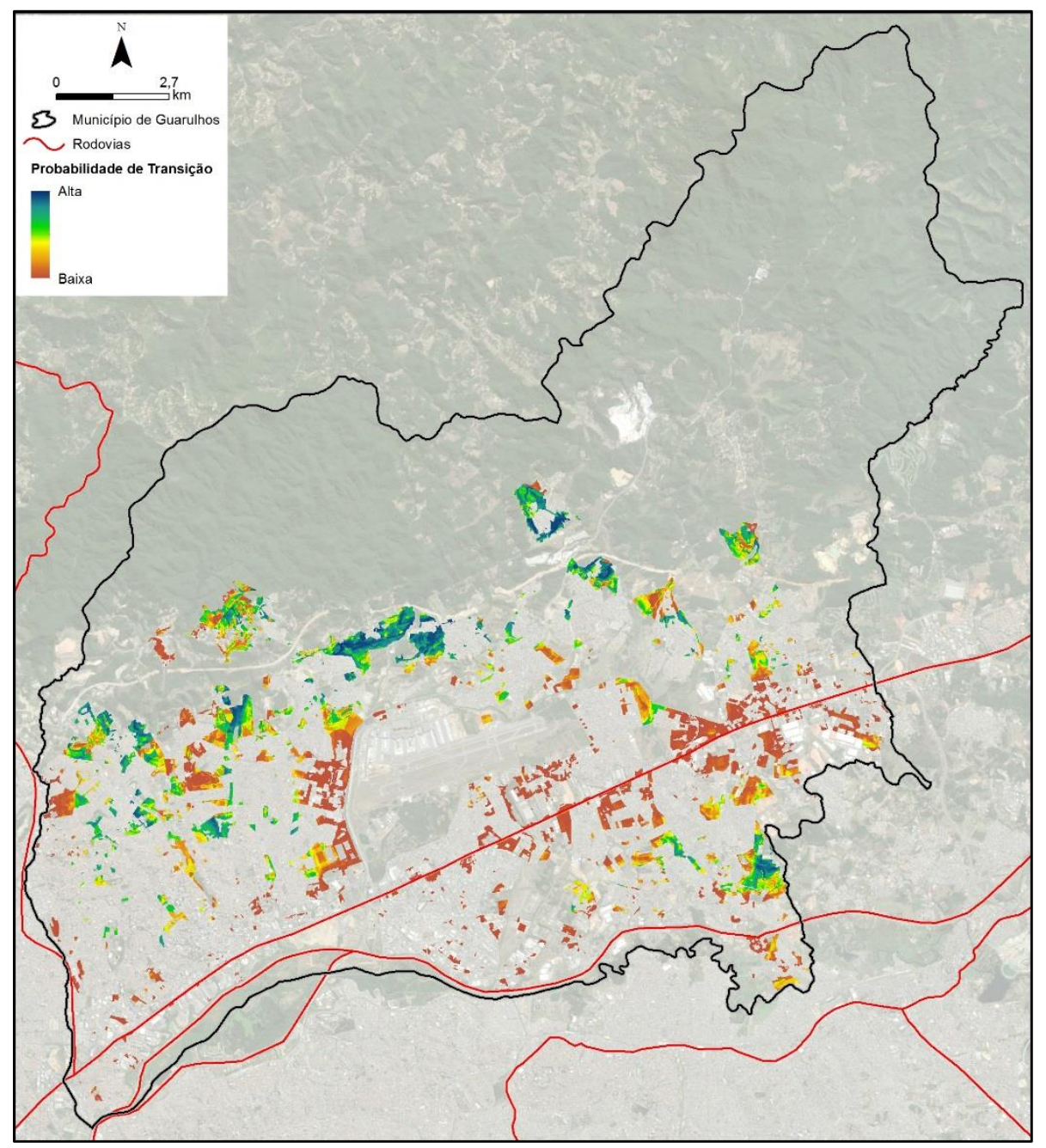

Figura 6.19 - Mapa de probabilidade de transição de Loteamento Desocupado para Urbano Regular no período entre 1993 e 2000. 


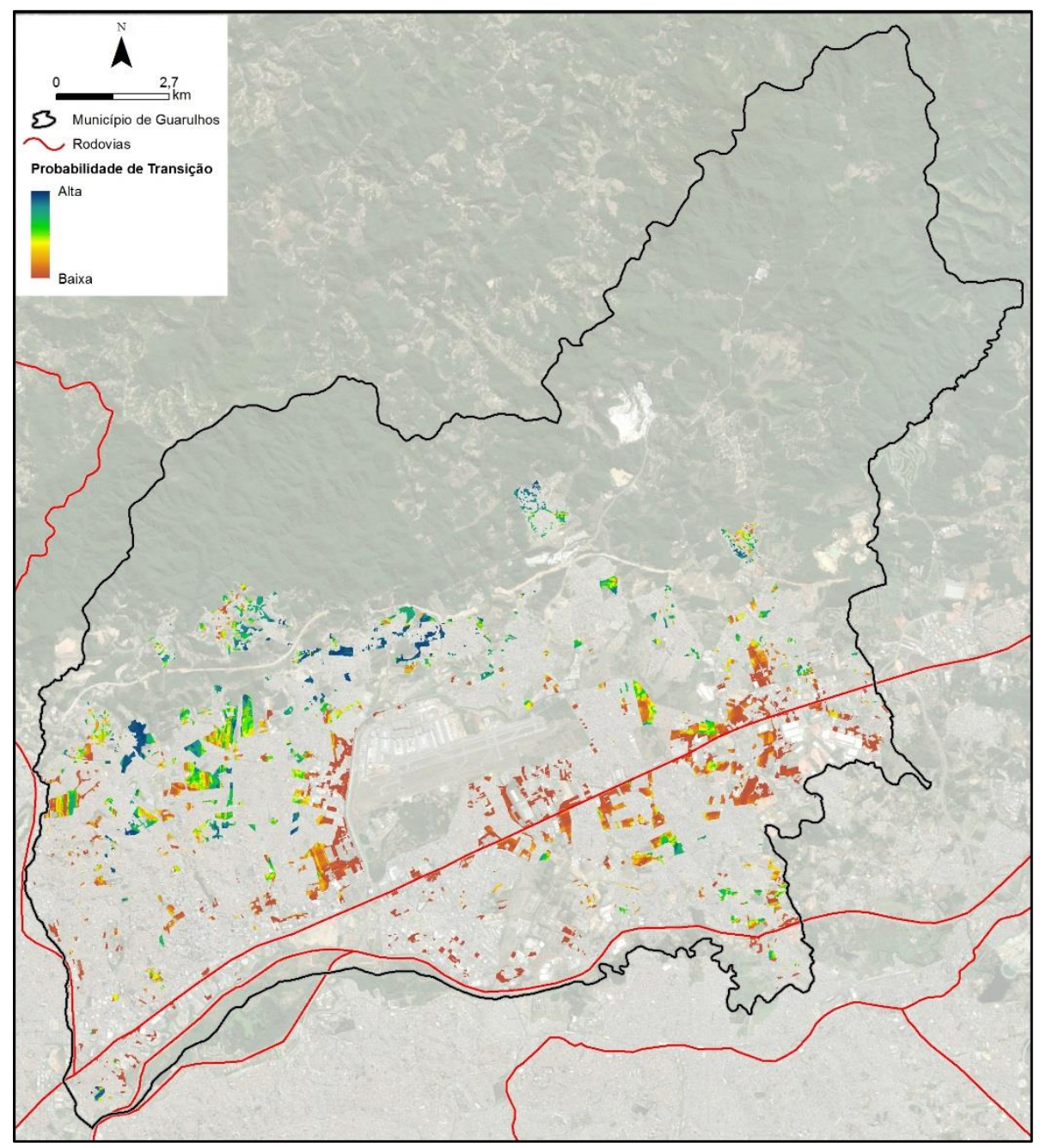

Figura 6.20 - Mapa de probabilidade de transição de Loteamento Desocupado para Urbano Regular no período entre 2000 e 2007. 
A sequência de mapas com as probabilidades da transição Loteamento Desocupado para Urbano Regular mostra claramente uma movimentação das áreas mais suscetíveis à transição em cada período.

No período entre 1986 e 1993, os loteamentos mais visados para ocupação estavam localizados no entorno do Aeroporto de Guarulhos, em áreas a leste, nordeste e norte do mesmo, ao passo que as áreas menos visadas correspondem aos terrenos localizados ao longo das rodovias, principalmente entre a Fernão Dias e Ayrton Senna. Destaca-se também a coesão da ocupação das transições deste período, marcada por manchas grandes e concentradas.

No período seguinte, que se estende entre 1993 e 2000, as áreas com maior probabilidade migram para locais mais afastados, ao longo de todo o setor norte do município de Guarulhos, ao mesmo tempo em que se dispersam pelo território, ocupando, cada uma, espaços mais reduzidos.

A tendência dessa movimentação e dispersão se mantém no último período analisado, quando as áreas com maiores probabilidades de transição se concentram quase que totalmente ao norte dos bairros centrais do município de Guarulhos.

\subsubsection{Transição de Campo / Capoeira para Urbano Regular}

Da mesma forma que ocorreu na transição de Loteamento Desocupado para Urbano Regular, também aqui a distância aos logradouros exerceu influência positiva até aproximadamente $50 \mathrm{~m}$ de distância nos três períodos analisados.

Por sua vez, a distância às vias estruturais exerce uma influência diferente em cada período. Entre 1986 e 1993, a influência que esta variável exerce é negativa até $200 \mathrm{~m}$ de distância, a partir de onde passa a exercer uma influência positiva crescente, chegando até $2.000 \mathrm{~m}$ de distância, quando então para de induzir esta transição. No período seguinte, de 1993 a 2000, a situação se inverte, e é possível verificar uma pequena influência positiva até $1.060 \mathrm{~m}$, passando a partir de então a atuar negativamente até $1.700 \mathrm{~m}$ de distância. No período final, entre 2000 e 2007, as transições se restringem a uma faixa maior ao redor destas vias estruturais, de modo que a influência é praticamente nula 
até $530 \mathrm{~m}$, quando então passa a apresentar valores de peso, na média, mais positivos.

Em relação às vias macrometropolitanas, no período entre 1986 e 1993, a proximidade a estas vias não resultou em influências particularmente negativas ou positivas, situando-se próximo de zero ao longo de todas as faixas de distâncias analisadas. Nos dois períodos seguintes, os valores oscilam fortemente entre positivo e negativo, indicando a baixa influência dessa variável na transição em questão.

A ocupação dos terrenos em função da declividade oferece um quadro sobre a ocupação do município de Guarulhos. É importante observar que no período entre 1986 e 1993 houve a maior expansão, em termos absolutos, da classe Urbano Regular sobre Campo / Capoeira. Nesse período, houve a ocupação de terrenos em áreas de baixa a alta declividade, entre 5\% e 25\%, a partir de onde a declividade passa a repelir esse tipo de transição. Nos anos seguintes, contudo, há uma tendência de ocupação dos terrenos com declividades mais elevadas, de modo que há uma influência positiva crescente à medida que a declividade aumenta.

É possível reparar ainda que a proximidade às indústrias é um repelente para a efetivação da transição da classe Campo / Capoeira para Urbano Regular, passando a exercer influência positiva à medida que se afasta das mesmas, aproximadamente por volta de 2.000 m no período de 1986 a 1993, decaindo para 750 m no período de 1993 a 2000, e 250 m no terceiro período. É interessante reparar que há uma tendência de aproximação às indústrias ao longo do período analisado, conforme Figura 6.21 a seguir.

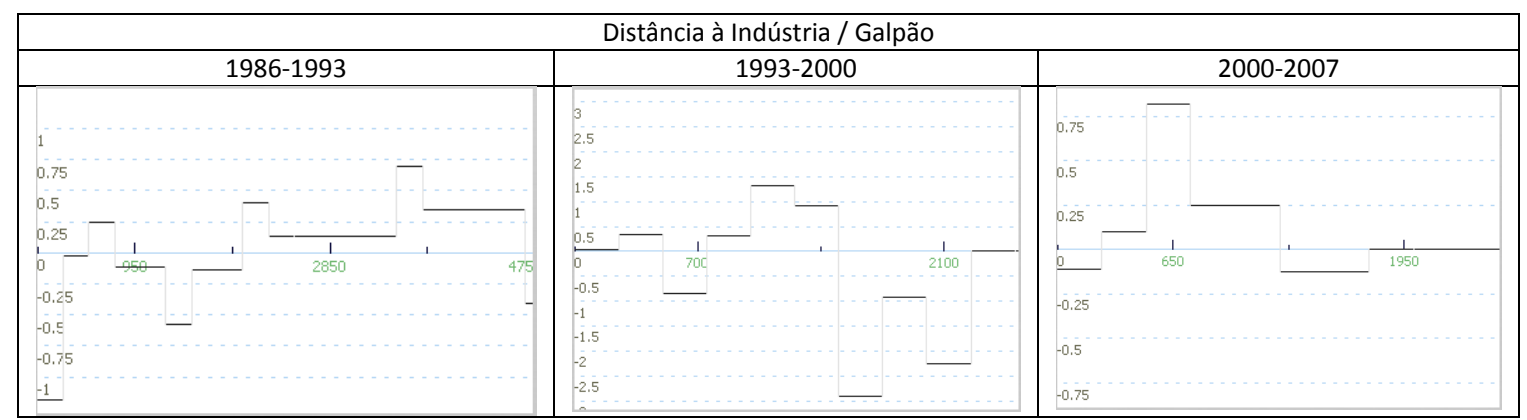

Figura 6.21 - Gráficos dos pesos de evidência com a variável de Distância à Indústria / Galpão. 
Por fim, a distância ao Aeroporto de Guarulhos fornece um panorama interessante nesta transição. Embora exista uma forte variação entre os valores positivos e negativos em função da distância ao aeroporto nos três períodos, estar próximo ao terminal aeroportuário atua como um repelente à ocupação urbana regular de terrenos ocupados por campos e capoeiras, tal como pode ser observado na Figura 6.22 a seguir. É importante destacar que essa característica repelente reflete uma condição esperada, já que o plano diretor do município restringe a ocupação ao redor do aeroporto, em função da possibilidade de quedas, choques com edificações e ruído.

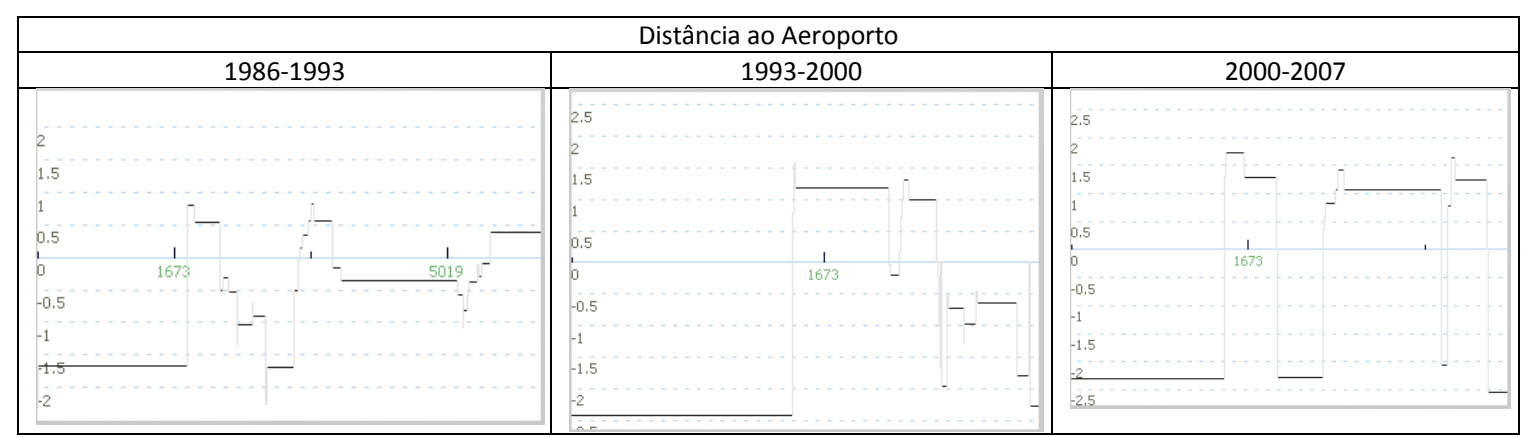

Figura 6.22 - Gráficos dos pesos de evidência com a variáveis de distância ao aeroporto.

A seguir, são apresentados os mapas de probabilidade para esta transição nos três períodos analisados, nas Figuras 6.23, 6.24 e 6.25. 


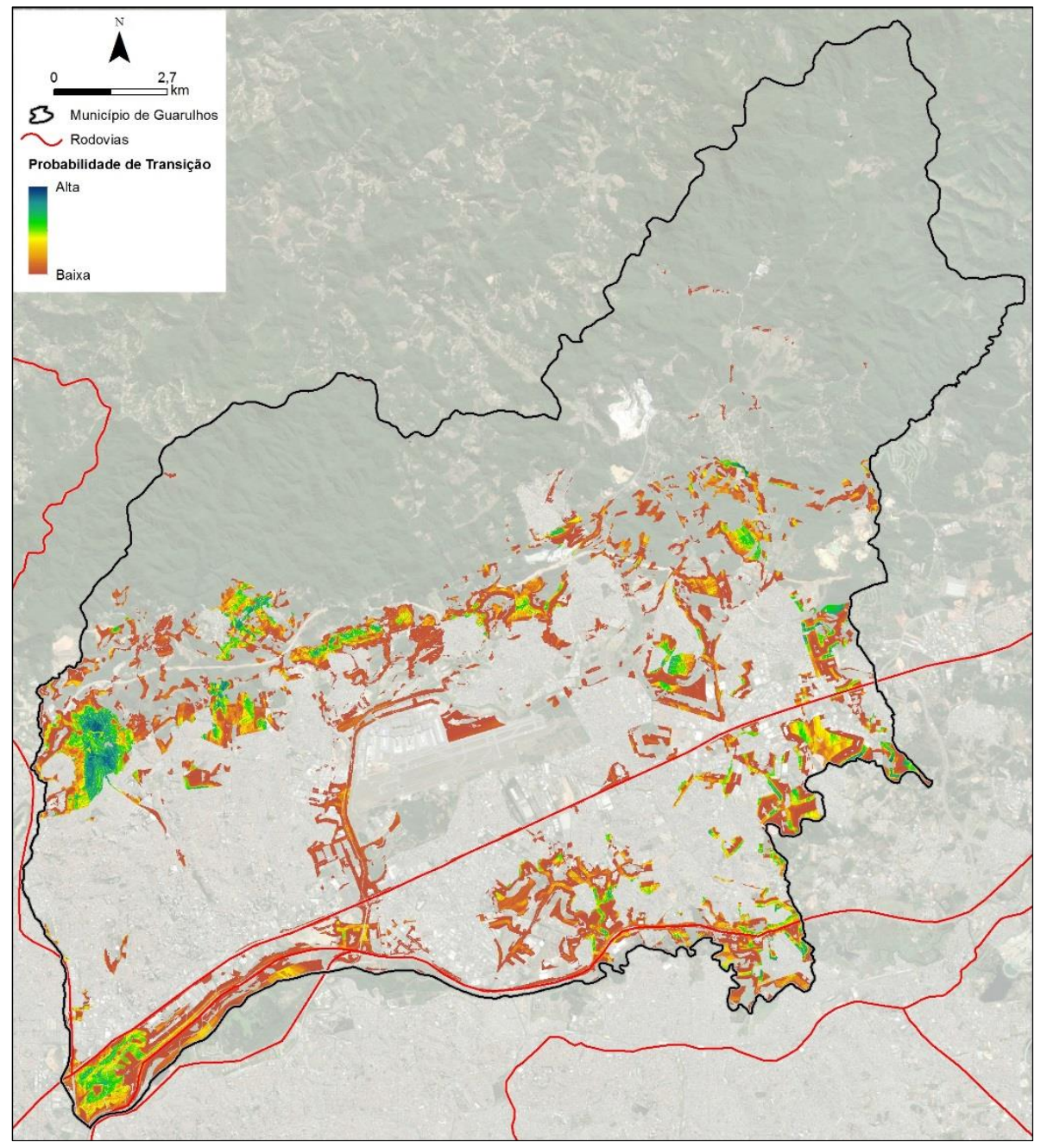

Figura 6.23 - Mapa de probabilidade de transição de Campo/Capoeira para Urbano Regular no período entre 1986 e 1993. 


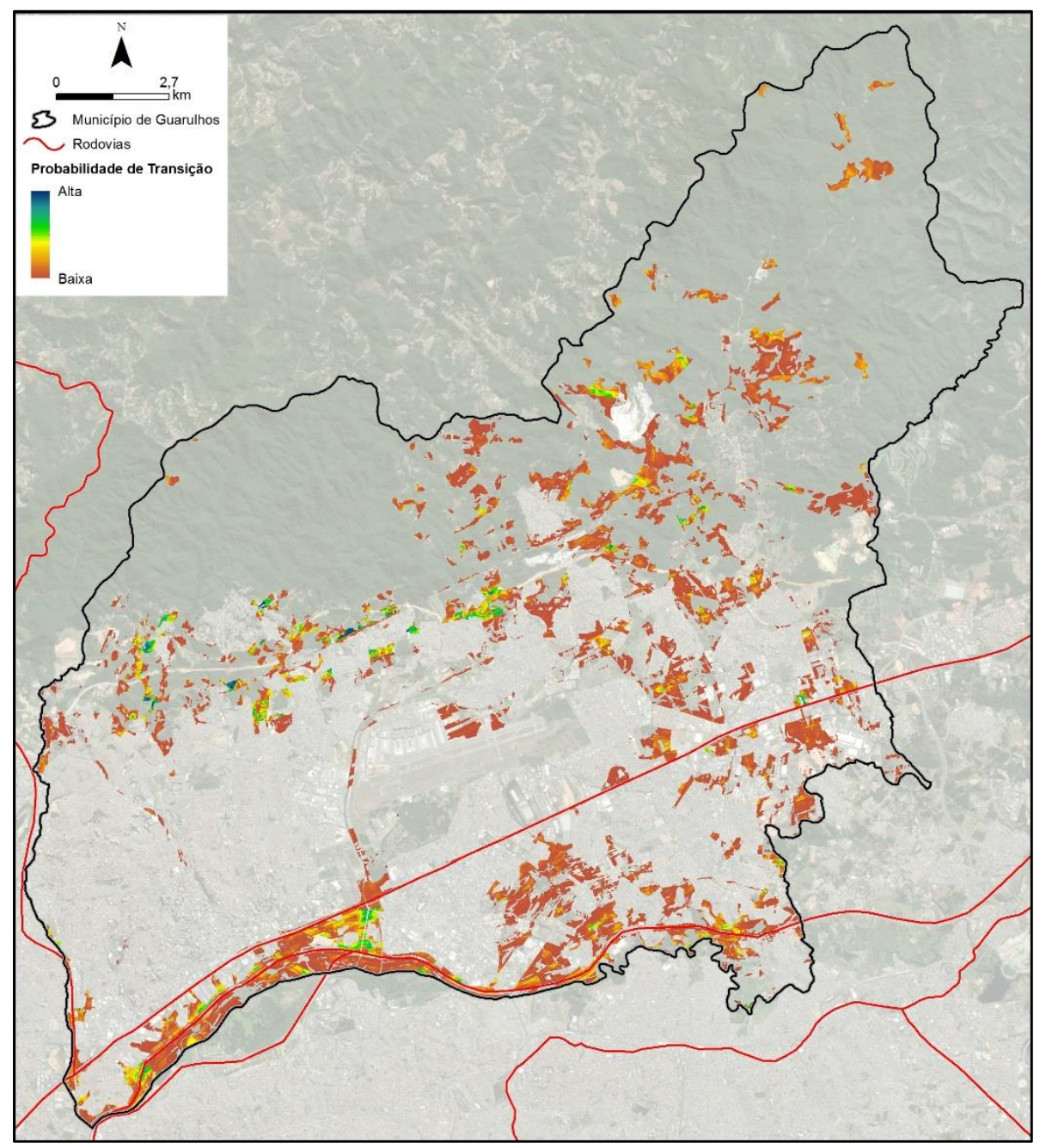

Figura 6.24 - Mapa de probabilidade de transição de Campo/Capoeira para Urbano Regular no período entre 1993 e 2000. 


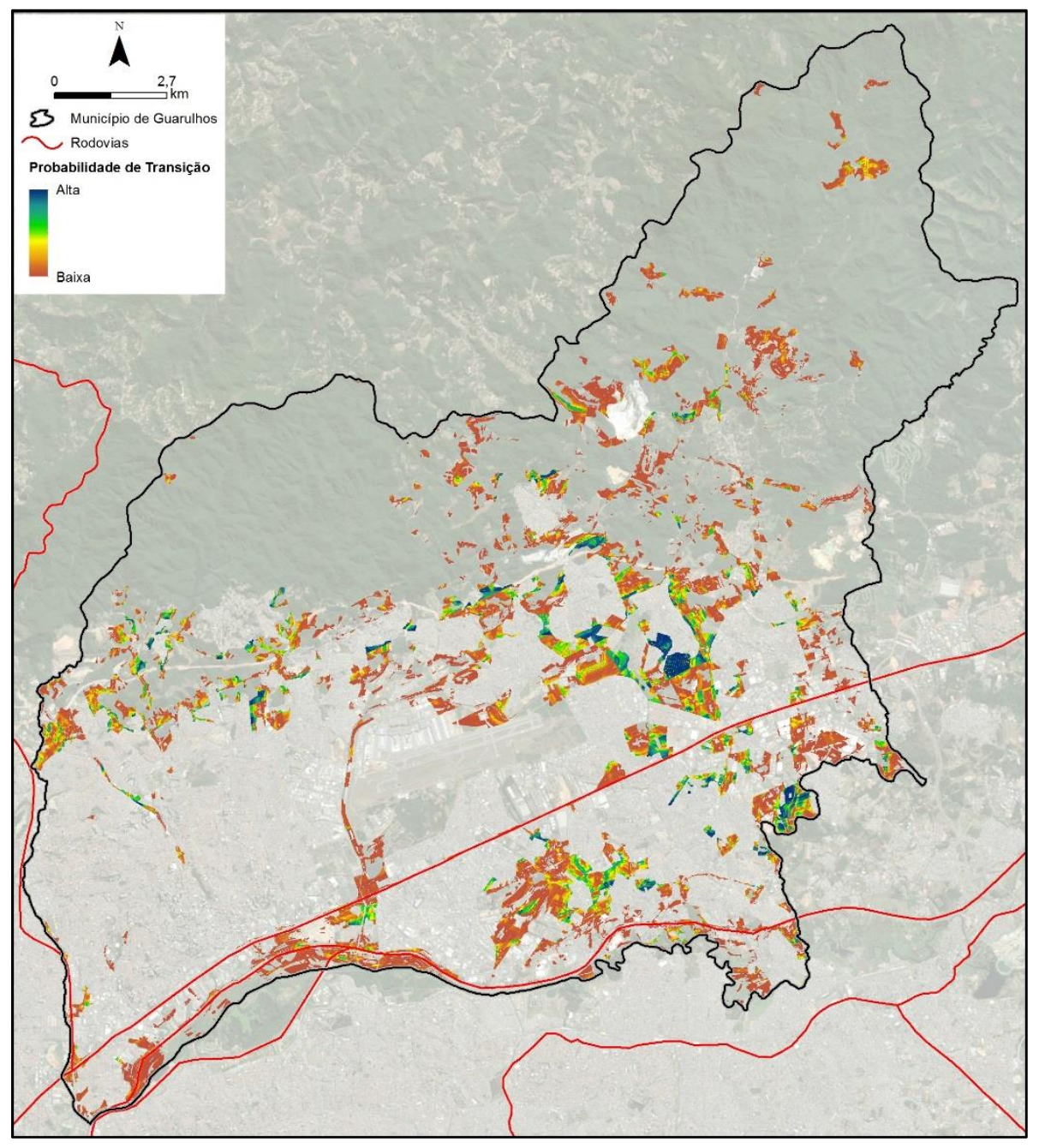

Figura 6.25 - Mapa de probabilidade de transição de Campo/Capoeira para Urbano Regular no período entre 2000 e 2007.

De modo geral, as áreas da transição de Campo / Capoeira para Urbano Regular têm as manchas de probabilidade espalhadas nos extremos das áreas urbanas do município ou entremeadas a elas. As áreas com maior probabilidade de acolher a transição no período entre 1986 e 1993 estão localizadas nos setores a noroeste e sudoeste do centro histórico de Guarulhos.

No período seguinte, entre 1993 e 2000, essas áreas com maior probabilidade ficam aglomeradas ao longo de todo o setor norte do município de Guarulhos. Como resultado da ocupação de áreas de maior declividade neste período, é possível verificar que algumas áreas com probabilidade mais reduzida se dispersam em direção a locais mais afastados e com maior declividade, no setor nordeste de Guarulhos. 
Por fim, o período compreendido entre 2000 e 2007 continua com as maiores probabilidades nas áreas mais afastadas, porém com menor abrangência, ao mesmo tempo em que surgem manchas de alta probabilidade para esta transição a leste do Aeroporto de Guarulhos e ao norte da rodovia Ayrton Senna.

\subsubsection{Transição de Loteamento Desocupado para Urbano Irregular}

A transição de Loteamento Desocupado para Urbano Irregular há influência positiva das áreas de baixa declividade nos períodos entre 1986 e 1993 e entre 2000 e 2007. A exceção para esta classe é o período entre 1993 e 2000, no qual as baixas declividades repelem a formação dos aglomerados irregulares até $10 \%$, a partir de onde existe uma influência positiva até $30 \%$ de declividade.

De forma geral, as proximidades das áreas livres às margens das vias estruturais apresentam repulsão nos três períodos analisados, sendo particularmente mais forte entre 1993 e 2000, quando os valores de pesos de evidência situam-se de torno de -2 até a distância de $1.500 \mathrm{~m}$, quando então essas áreas passam a ter uma influência positiva. Da mesma forma, as vias macrometropolitanas exercem uma influência repelente nos assentamentos irregulares, pelo menos até $1.000 \mathrm{~m}$ de distância, conforme pode ser observado na Figura 6.26 abaixo.

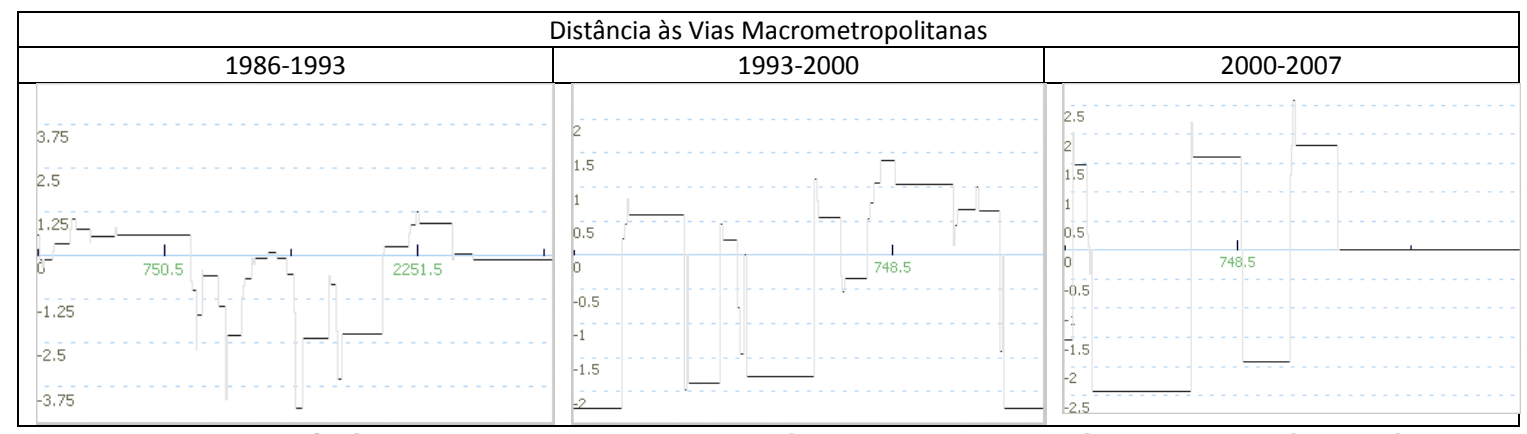

Figura 6.26 - Gráficos dos pesos de evidência com a variável de Distância às Vias Macrometropolitanas

É importante destacar o papel da indústria como uma variável influenciadora da transição de Loteamento Desocupado para a classe Urbano Irregular. De forma geral, os terrenos nas proximidades das indústrias tendem a atrair esse tipo de ocupação, de forma que ela induz à formação de núcleos 
irregulares, particularmente no período entre 2000 e 2007, quando a única influência é positiva. No período entre 1986 e 1993 e entre 1993 e 2000, a influência sofre uma variação em função da distância à indústria, conforme pode ser atestado no gráfico abaixo.

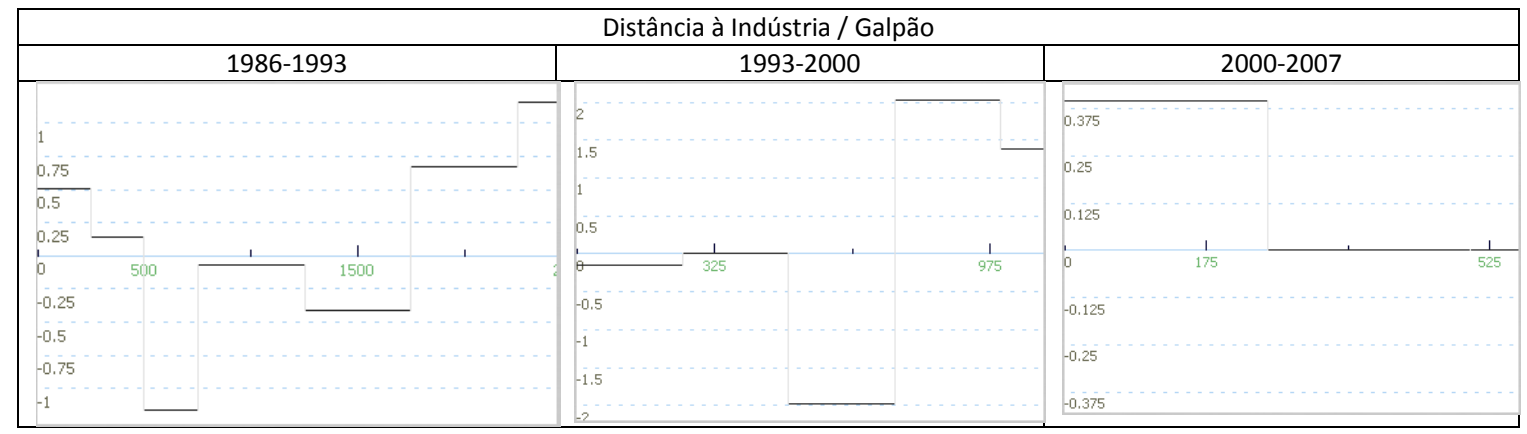

Figura 6.27 - Gráficos dos pesos de evidência com a variáveis de distância à indústria / galpão.

No que se refere à variável da distância ao aeroporto é interessante constatar que no período entre 1986 e 1993, que compreende os primeiros anos após a inauguração dele, a influência exercida por ele foi positiva até os 1.200 m de distância, porém, nos períodos seguintes, que compreendem os anos entre 1993 e 2007, a influência do aeroporto foi repelente para esse tipo de transição até quase $2.000 \mathrm{~m}$ de distância. A Figura 6.28 abaixo apresenta claramente estes termos.

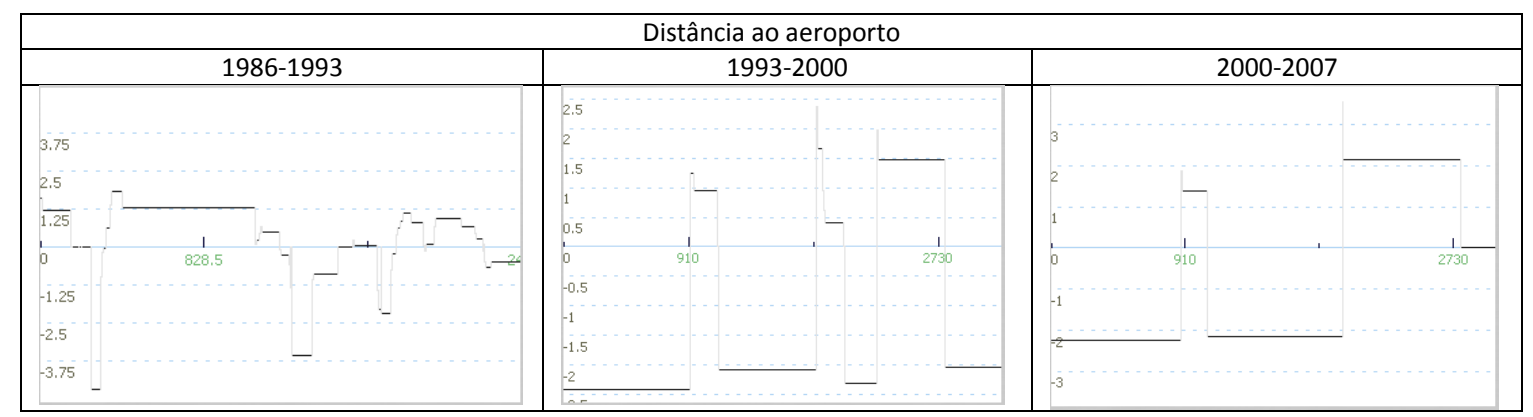

Figura 6.28 - Gráficos dos pesos de evidência com a variáveis de distância ao aeroporto.

A seguir são apresentados os mapas de probabilidade para esta transição nos três períodos analisados, nas Figuras 6.29, 6.30 e 6.31. 


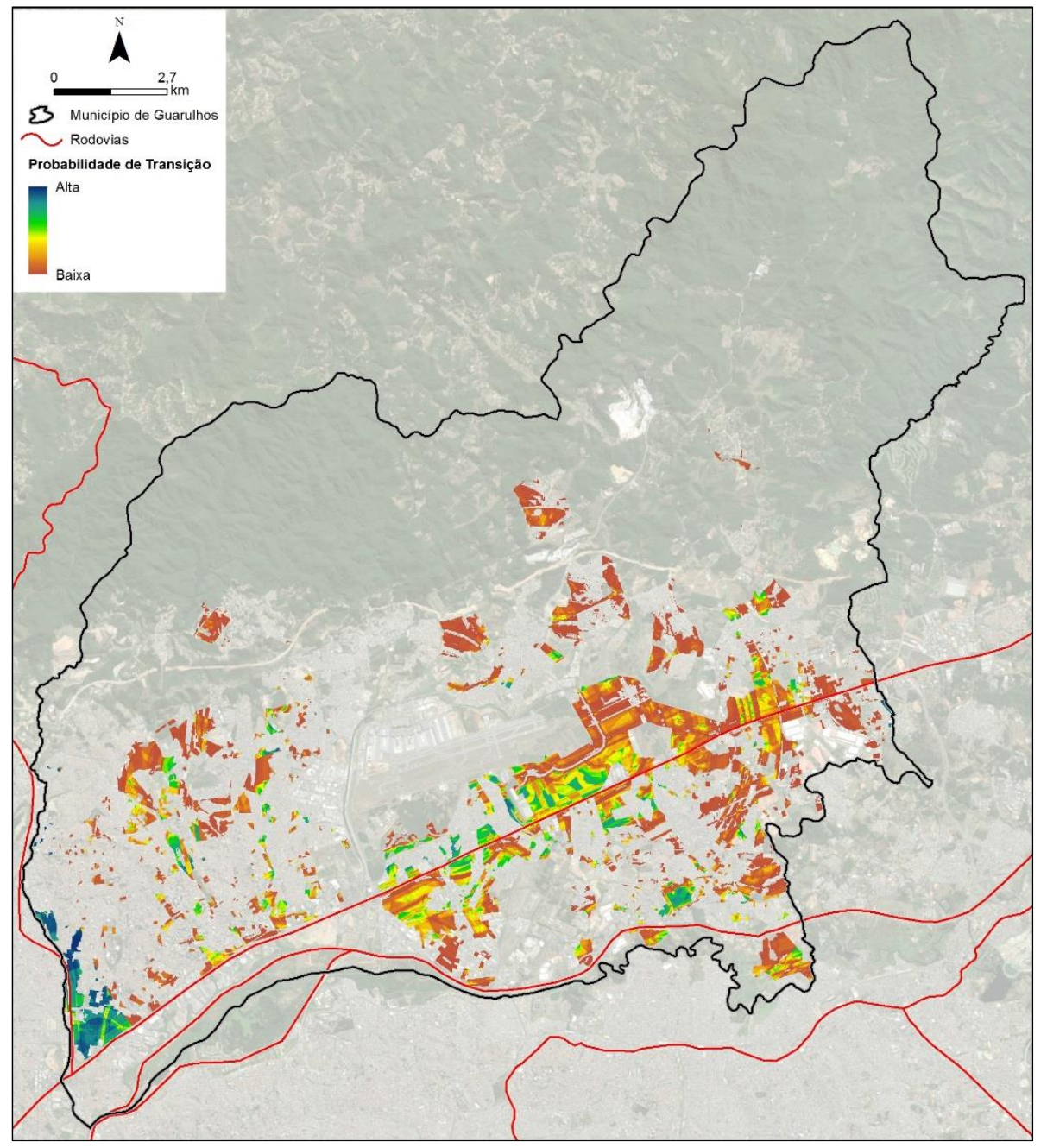

Figura 6.29 - Mapa de probabilidade de transição de Campo/Capoeira para Urbano Irregular no período entre 1986 e 1993. 


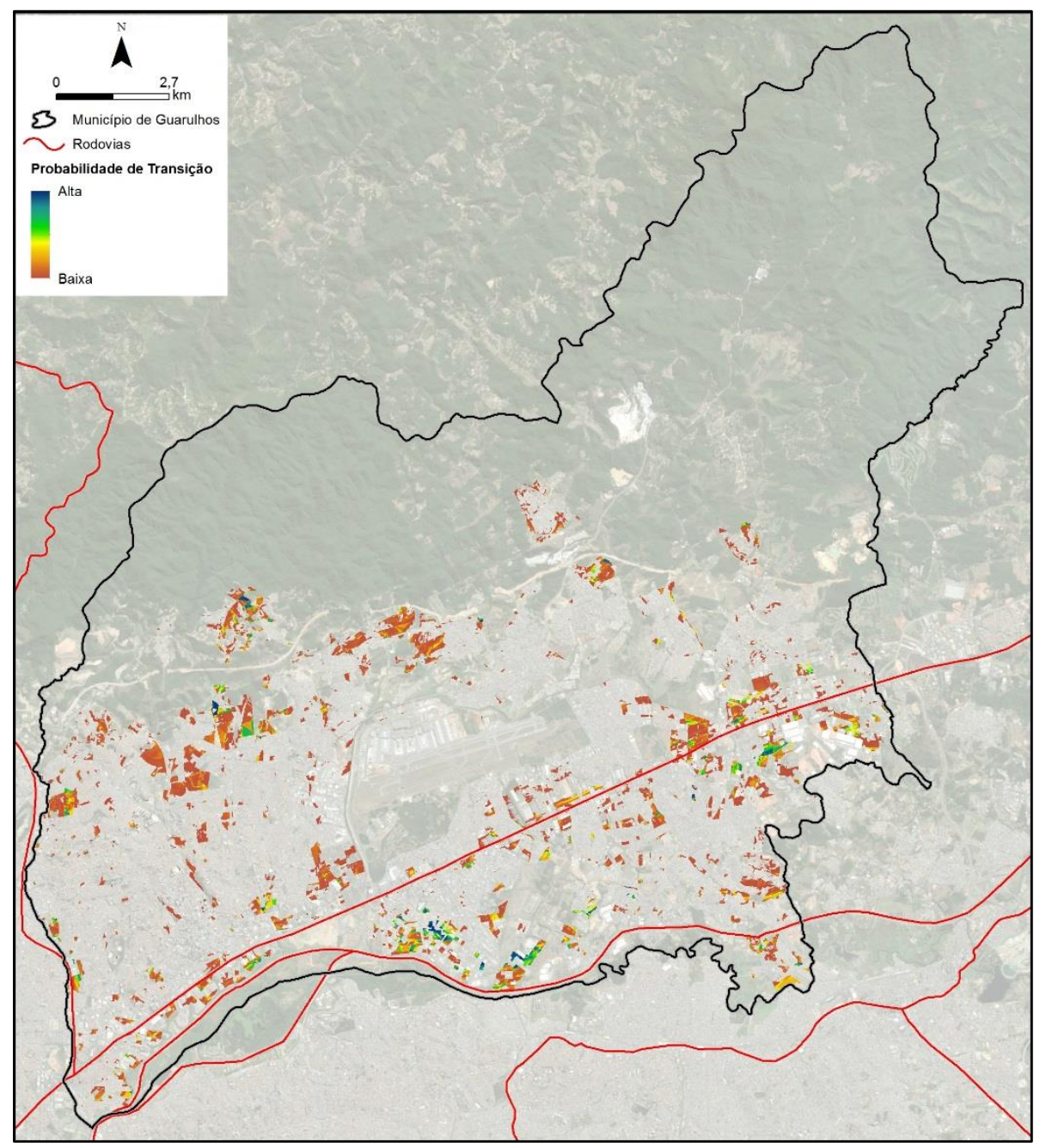

Figura 6.30 - Mapa de probabilidade de transição de Campo/Capoeira para Urbano Irregular no período entre 1993 e 2000. 


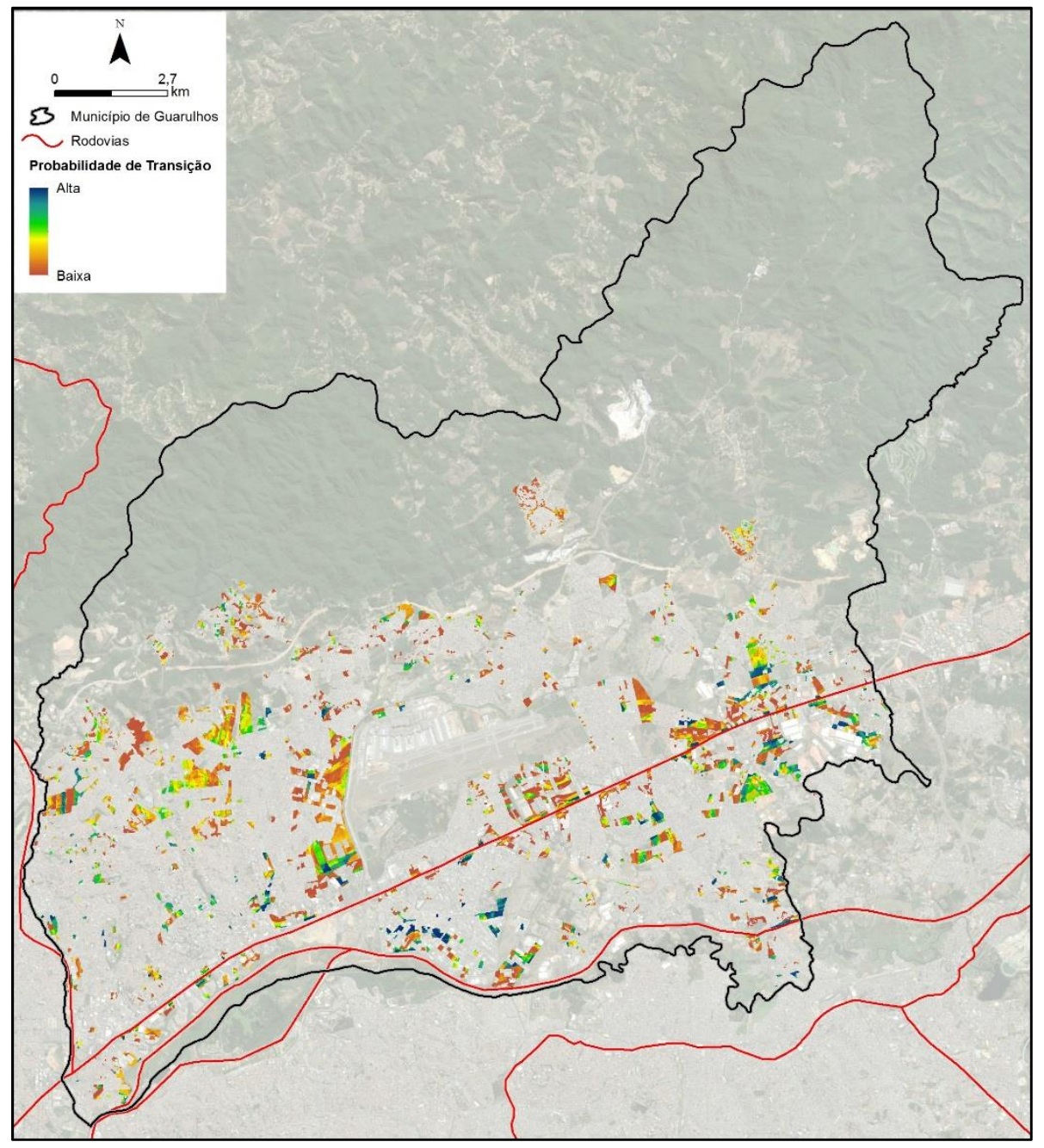

Figura 6.31 - Mapa de probabilidade de transição de Campo/Capoeira para Urbano Irregular no período entre 2000 e 2007.

Tal como na transição Loteamento desocupado para Urbano regular, a transição de Campo/ Capoeira para Urbano regular sofreu uma forte movimentação nas áreas mais suscetíveis à transição em cada período.

No período entre 1986 e 1993 os loteamentos mais visados para ocupação estavam localizados a oeste do município, na proximidade da rodovia Fernão Dias, além de áreas com média probabilidade ao longo da rodovia Presidente Dutra.

No período seguinte, que se estende entre 1993 e 2000, as áreas com maior probabilidade à transição migram para locais ao sul da rodovia presidente Dutra, sendo mais comum a transição entremeadas às indústrias, ao mesmo tempo que se dispersam pelo território, ocupando espaços mais reduzidos. 
No período seguinte essa movimentação ganha mais importância e quase todas as manchas com a maior probabilidade de transição se encontram entre as rodovias Presidente Dutra e Ayrton Senna, com outras pequenas manchas surgindo tanto a oeste como a leste do aeroporto.

\subsubsection{Transição de Loteamento desocupado para Indústrias/ Galpões}

Uma das modificações mais importantes ocorridas na paisagem do município ao longo das décadas analisadas, foi transição dos loteamentos desocupados para áreas industriais e galpões. Isso porque essa transformação foi um eixo catalisador para a expansão da rede urbana como um todo, dada a quantidade de pessoas, serviços e infraestrutura que um amplo pátio industrial e terminais logísticos demandam.

No que se refere às distâncias com os logradouros há uma influência positiva até os $50 \mathrm{~m}$ de distância no período entre 1986 e 1993, ao passo que nos dois períodos seguintes, a proximidade com os logradores repele a transição até os $85 \mathrm{~m}$ de distância, a partir de onde ela começa a favorecer a expansão desta classe de uso e cobertura da terra.

Por sua vez, a distância para as vias estruturais exerce uma essencialmente positiva nesta transição, de modo que influencia positivamente nos três períodos entre $400 \mathrm{~m}$ e até $750 \mathrm{~m}$ de distância, conforme pode ser observado na Figura 6.32 a seguir.

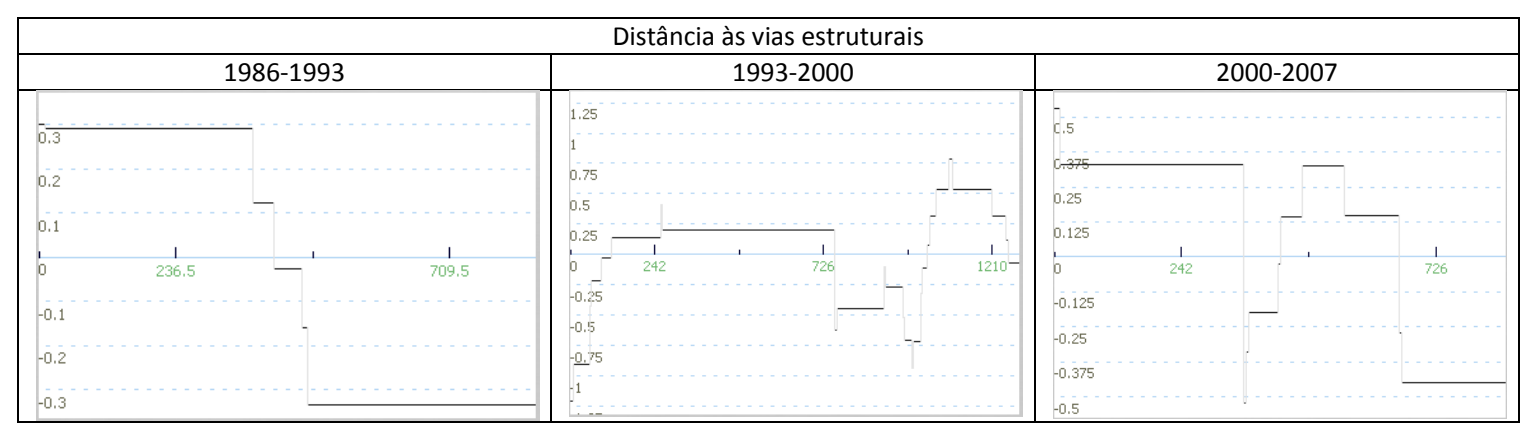

Figura 6.32 - Gráficos dos pesos de evidência com a variável da distância à classe Vias Estruturais.

No que se refere às vias macrometropolitanas a relação com a transição dos loteamentos desocupados para industrias e galpões se torna especialmente clara. De uma forma geral, os três períodos apontam para uma influência positiva da transição nas áreas que estão próximas a estas vias variando em distância 
entre 1.080 e 1.400 m nos três períodos. Para além destas distâncias a variável passa a repelir a transição para indústria / galpão, conforme pode ser observado na Figura 6.33, a seguir.

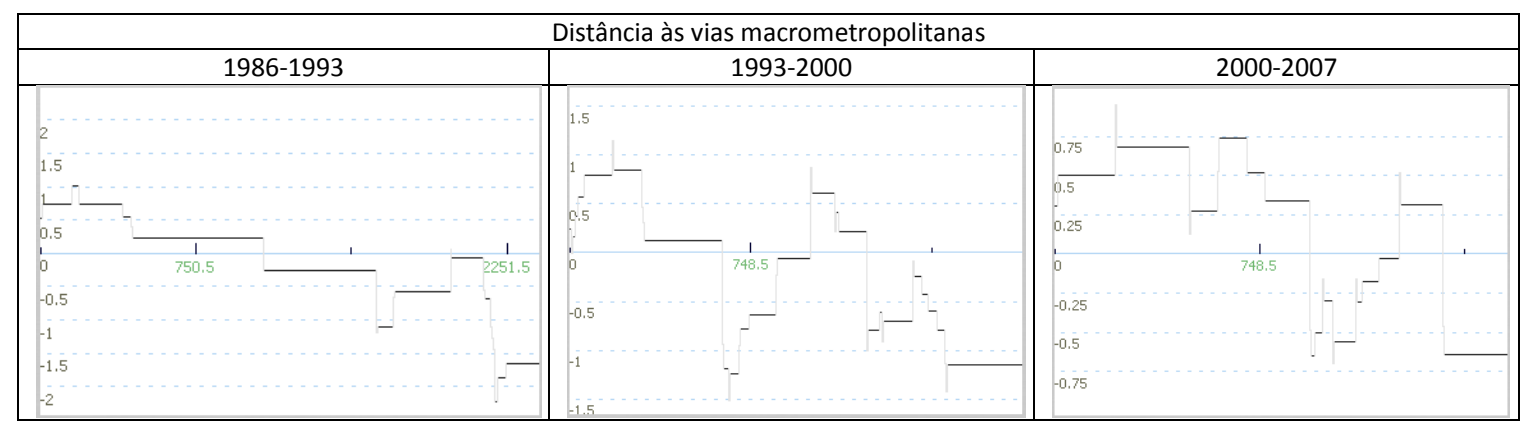

Figura 6.33 - Gráficos dos pesos de evidência com a variável da distância à classe Declividade.

A ocupação dos loteamentos desocupados por indústrias e galpões é fortemente favorecida por baixas declividades, como pode ser constatado na Figura 6.34, onde é possível verificar que só há uma influência positiva até os $10 \%$ de declividade, sendo que para além disso há uma constante repelência do terreno para este tipo de transição.

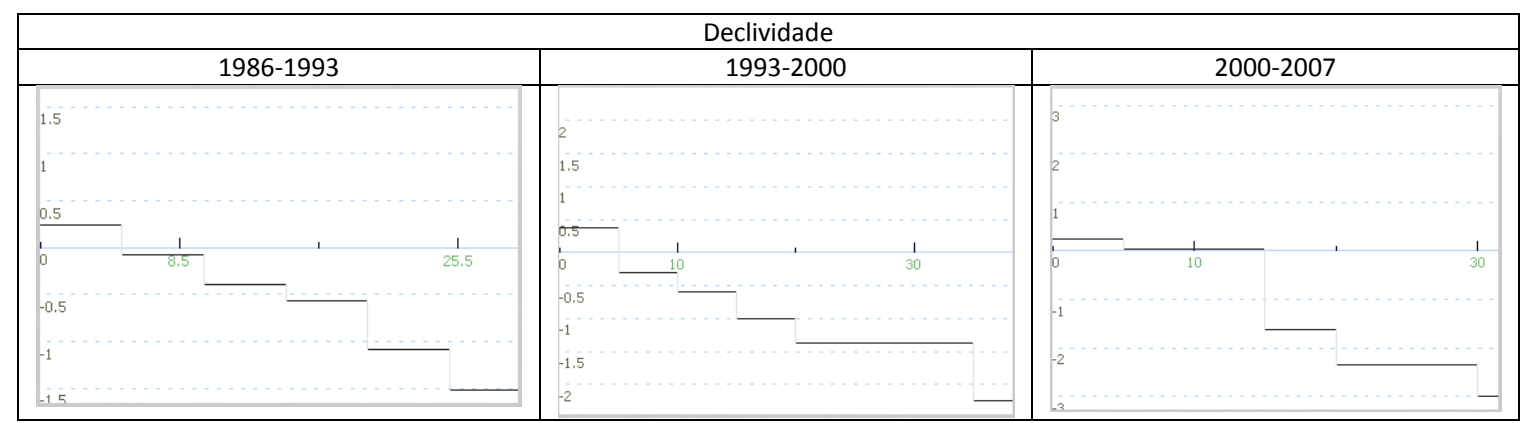

Figura 6.34 - Gráficos dos pesos de evidência com a variável da distância à classe Declividade.

De maneira geral, esse tipo de transição recebe influência positiva à medida que se afasta das áreas ocupadas por elementos da classe urbano regular, iniciando em torno dos $200 \mathrm{~m}$ de distância e crescendo a influência à medida que se afasta, como pode ser observado na Figura 6.35. 


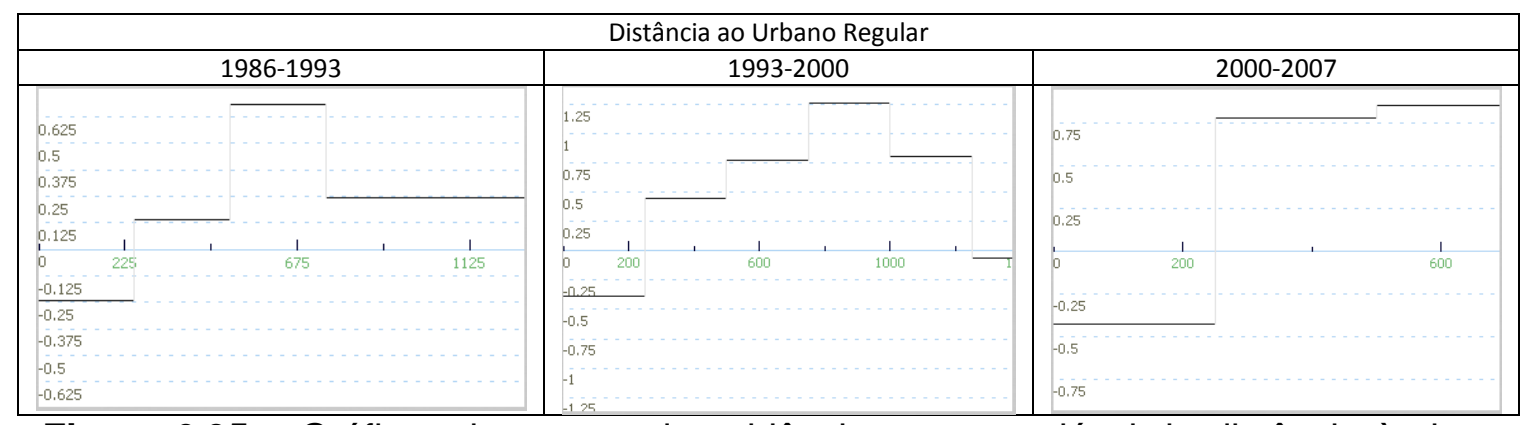

Figura 6.35 - Gráficos dos pesos de evidência com a variável da distância à classe Urbano Regular.

Por fim, a distância ao Aeroporto de Guarulhos fornece um panorama interessante nesta transição. Embora exista uma forte variação entre os valores positivos e negativos em função da distância com o aeroporto, nos três períodos estar próximo ao terminal aeroportuário resulta em um atrativo para a ocupação por industrias e galpões como pode ser observado na Figura 6.36 a seguir.

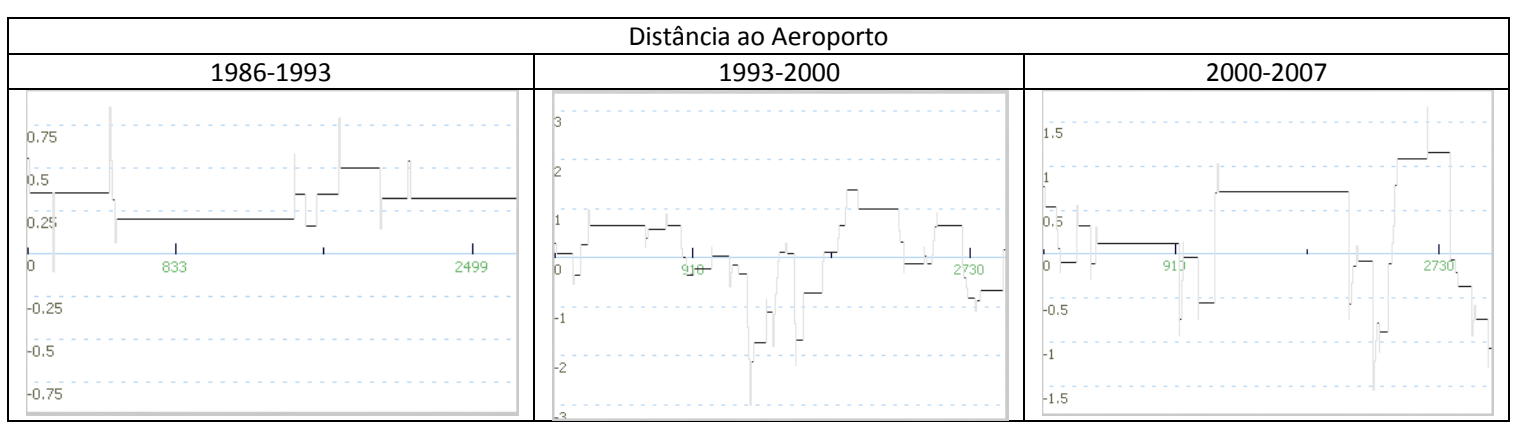

Figura 6.36 - Gráficos dos pesos de evidência com a variável de distância ao aeroporto.

A seguir são apresentados os mapas de probabilidade para esta transição nos três períodos analisados, nas Figuras 6.37, 6.38 e 6.39 . 


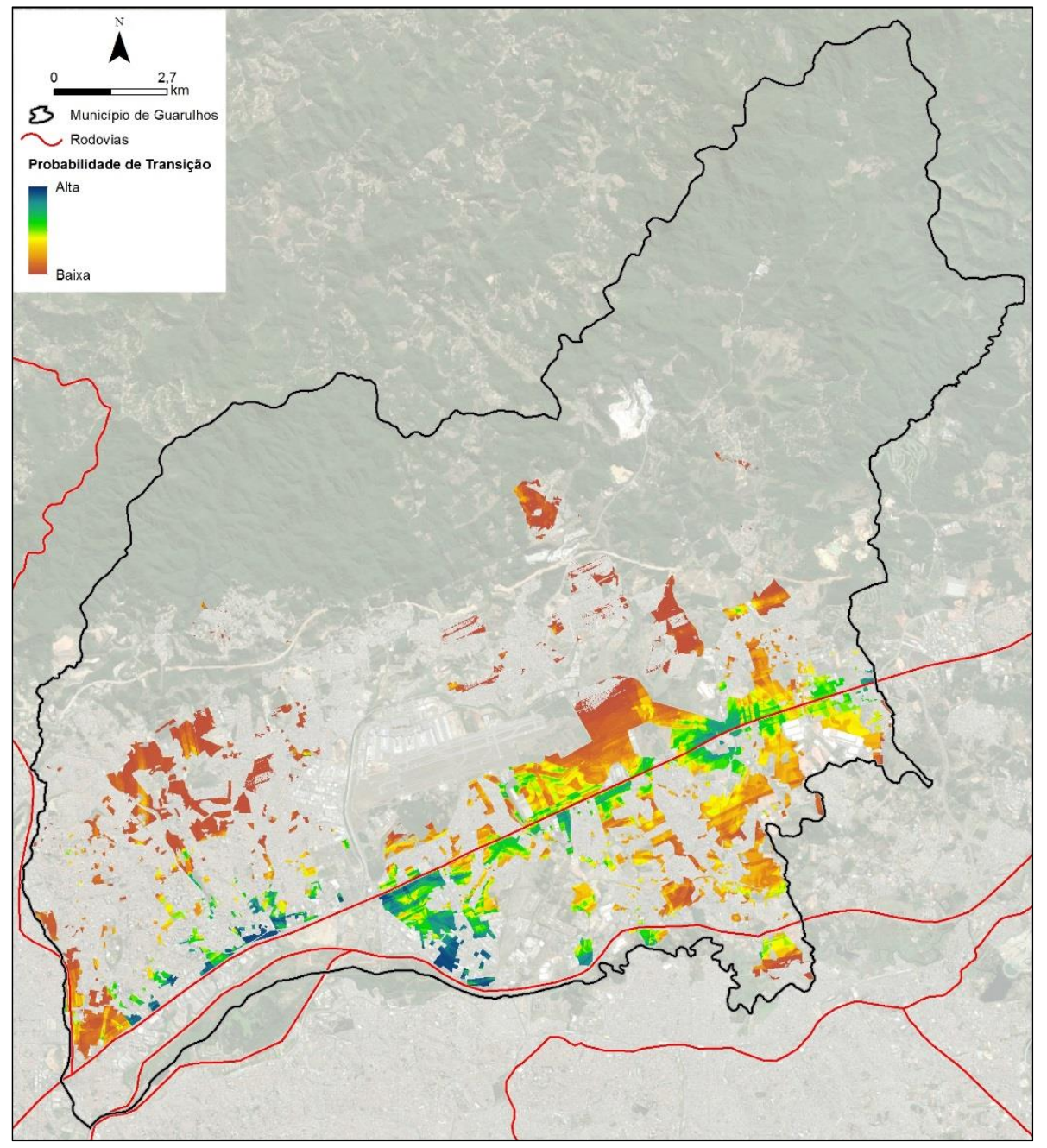

Figura 6.37 - Mapa de probabilidade de transição de Loteamento desocupado para Indústria/ Galpão no período entre 1986 e 1993. 


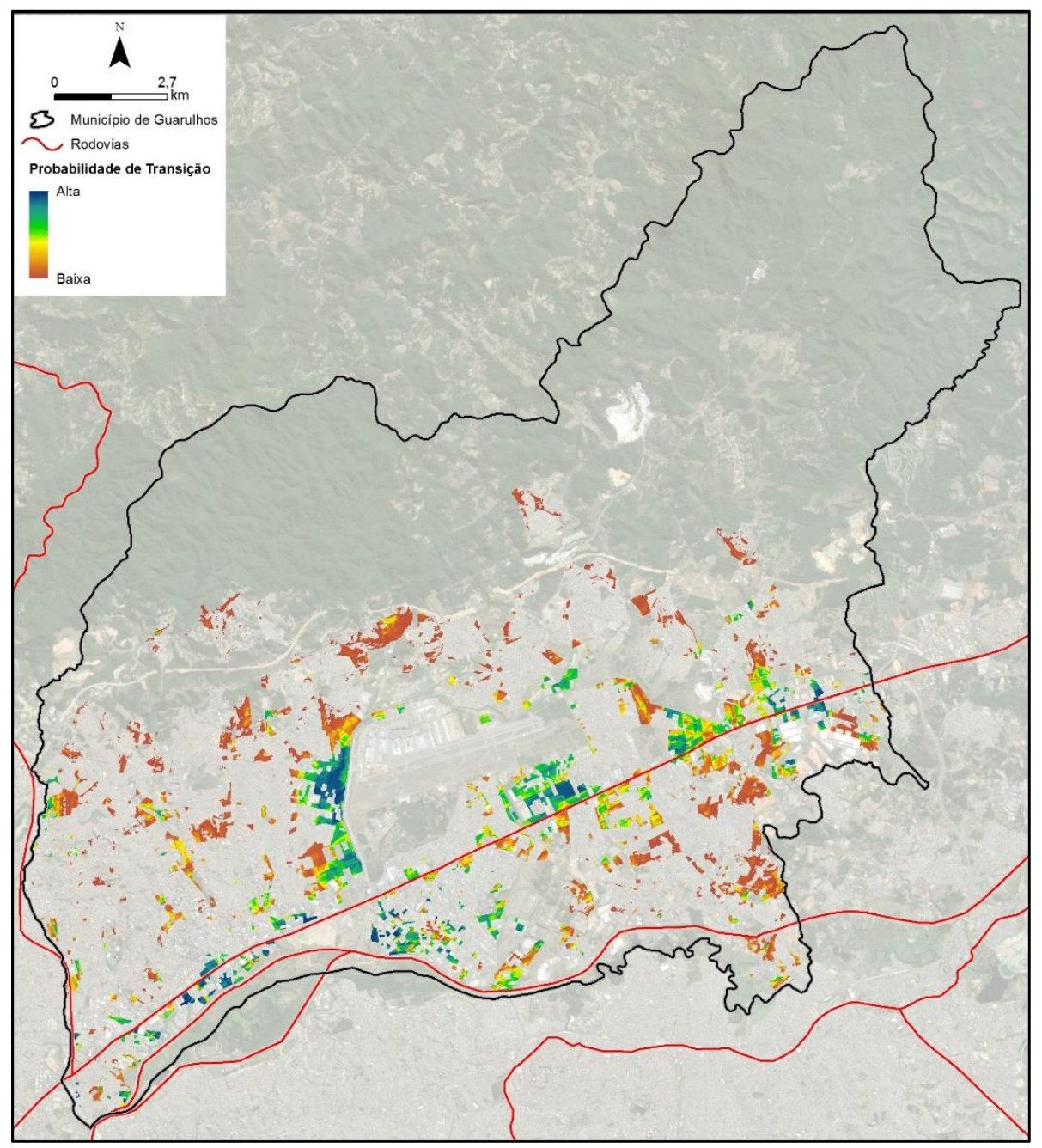

Figura 6.38 - Mapa de probabilidade de transição de Loteamento desocupado para Indústria/ Galpão no período entre 1993 e 2000. 


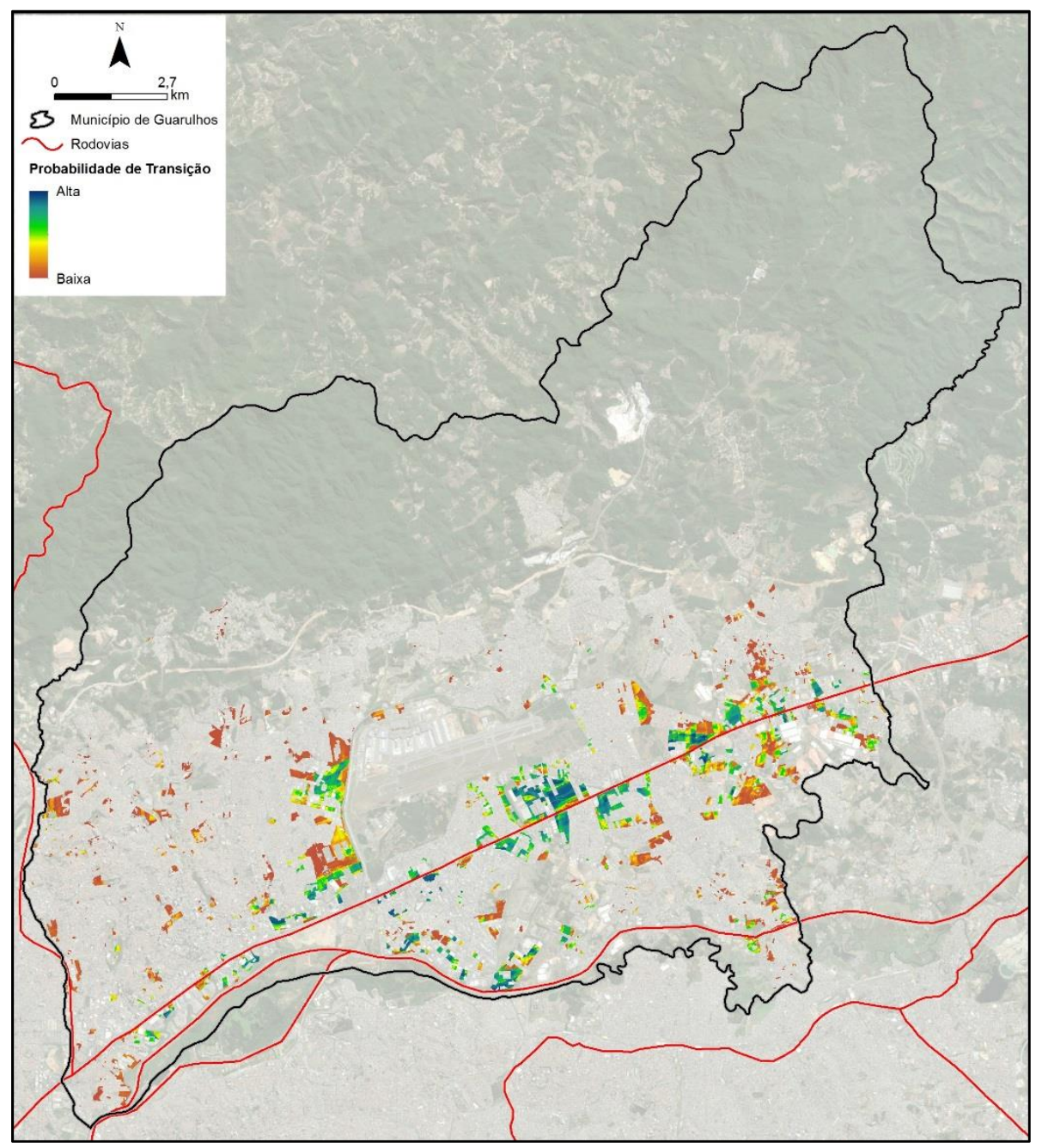

Figura 6.39 - Mapa de probabilidade de transição Loteamento desocupado para Indústria/ Galpão no período entre 2000 e 2007.

É possível verificar que no período entre 1986 e 1993 as probabilidades de transição de Loteamento desocupado para Industria/Galpão ficaram fortemente vinculados à proximidade com as rodovias, tendo se concentrado principalmente no entorno da Rodovia Presidente Dutra. Nos dois períodos seguintes as áreas com probabilidade de sofrer essa transição ficaram mais restritas e mantiveram uma tendência de concentrar-se ao redor da rodovia. Além disso, a probabilidade de transição ao redor do aeroporto ganha mais força e se consolida tanto a oeste como ao sul do terminal. 


\subsection{Considerações sobre os Mapeamentos, Matrizes de Transição e Pesos de Evidência}

A leitura visual dos mapas de cobertura e uso da terra e a análise dos percentuais de área para cada classe nos anos investigados apresentados na Tabela 6.3 e Figuras 6.2, 6.3, 6.4 e 6.5, em conjunto com as matrizes de transição e pesos de evidência, obtidos como parte do processamento necessário para as simulações no Dinamica-EGO, foram interpretadas à luz de pesquisas já realizadas em Guarulhos, dentre as quais destaca-se a pesquisa conduzida por Lasalvia (2006). Este exercício permitiu, em primeiro lugar, que fossem destacados os principais eixos de crescimento urbano e, em um segundo momento, a identificação dos elementos que provocaram maior ou menor influência nas transições observadas.

O mapa de cobertura e uso da terra de 1986 indica onde as populações que se dirigiram a Guarulhos até este ano se fixaram. Por sua vez, a comparação com os anos seguintes indica o eixo de crescimento das áreas ocupadas pelos novos contingentes populacionais. A quantificação dessas classes aponta 0 rápido crescimento de áreas destinadas a residências entre 1986 e 2000, passando de 42,4 km² em 1986, para 58,3 km² em 1993 e 67,7 km² em 2000, tendo um crescimento menos expressivo no ano de 2007, quando atingiu a área de $70,82 \mathrm{~km}^{2}$. As taxas de crescimento destas classes são de $37,5 \%$ entre 1986 e 1993, 16,1\% entre 1993 e 2000 e 4,6\% entre 2000 e 20007.

De modo geral, as matrizes de transição apontam que os Loteamentos desocupados perfazem a principal origem das áreas urbanas regulares que surgiram em todo o período, sendo mais expressivos entre 1986 e 1993 e entre 1993 e 2000. De fato, no primeiro período esse tipo de transição representou $27,5 \%$ das transições ocorridas sobre os Loteamentos desocupados no primeiro período e $28,6 \%$ no período seguinte, caindo para 12\% entre 2000 e 2007 .

Esse forte crescimento foi impulsionado pela conjuntura de Guarulhos na segunda metade do século XX. De modo geral, conforme Lasalvia (2006), a posição geográfica de Guarulhos no eixo Rio-São Paulo, limítrofe à capital paulistana e a oferta de um conjunto razoável de terrenos planos disponíveis com preço baixo em relação aos praticados em São Paulo, foram elementos 
preponderantes para que o município absorvesse um grande contingente populacional.

Buscando compreender o que vinha motivando as pessoas a buscarem Guarulhos como alternativa de residência, foi realizada uma pesquisa no final da década de 1969 com 600 moradores recentes dos municípios, cujas perguntas estruturadas orbitavam sobre as razões que levaram tais pessoas para lá. O resultado apontou que $47 \%$ dos moradores estavam interessados nos valores mais baixos dos alugueis, imóveis e terrenos, enquanto que o emprego do chefe de família era apontado como motivo para $28 \%$ dos entrevistados Wilheim (1969).

A Figura 6.40 apresenta as áreas ocupadas por áreas urbanas regulares nos períodos analisados.

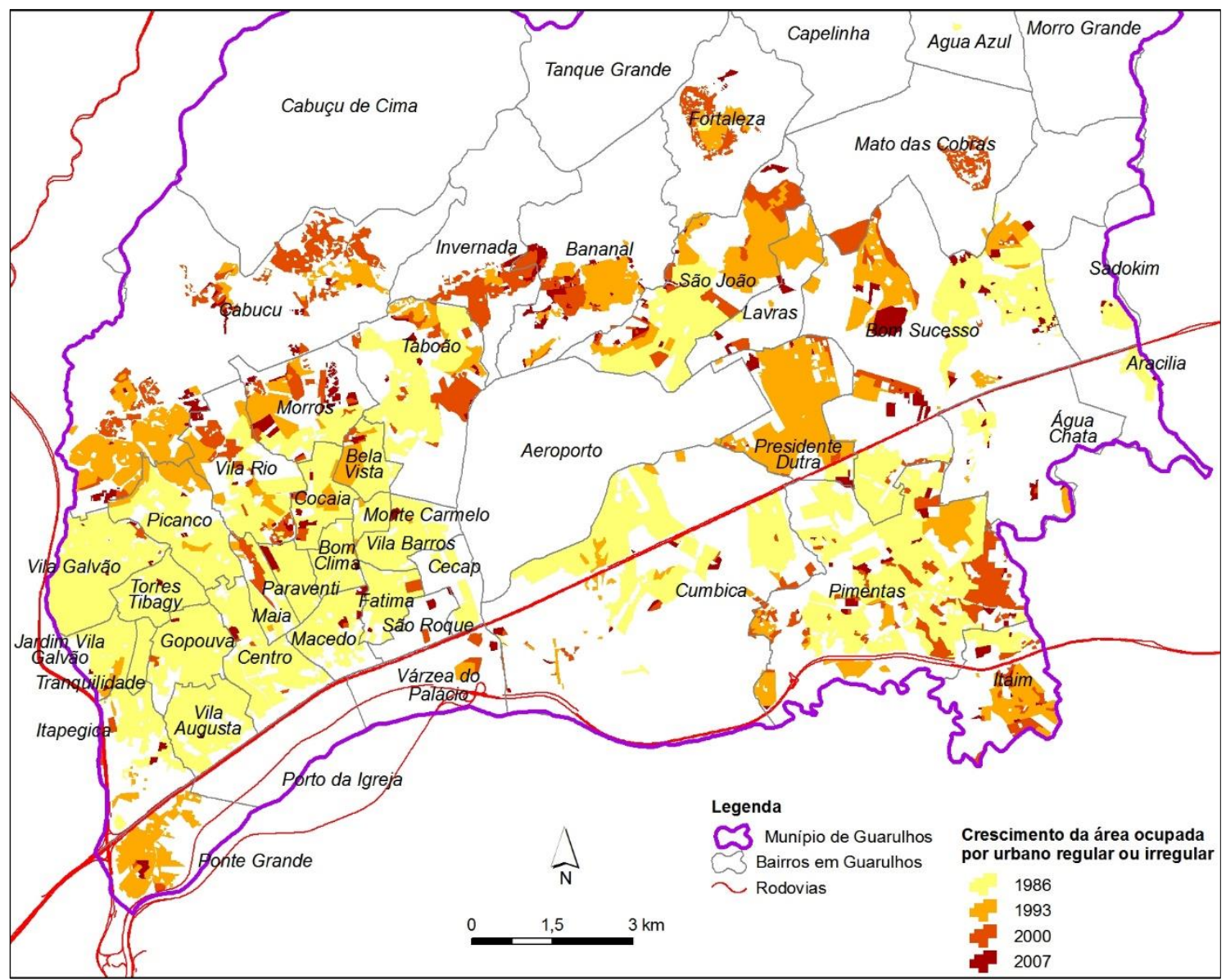

Figura 6.40 - Crescimento das Classe Urbano regular e Urbano irregular no município de Guarulhos

Como pode ser observado na Figura 6.40, no período entre 1986 e 1993 houve um movimento populacional que circunscreveu três áreas mais 
significativas. A primeira delas, ao norte dos bairros centrais, resultou na ocupação dos bairros Cabuçu e Morros, além do crescimento da área urbana nos bairros de Bela Vista e Vilário. A segunda grande área de expansão deste período está localizada ao norte e oeste do aeroporto de Guarulhos, inaugurado em 1985, de modo que a ocupação se expandiu nos bairros de Bananal, São João e Bom Sucesso. Além destes, neste período surgiram novos núcleos de ocupação no bairro de Fortaleza, e Presidente Dutra. Por fim, uma terceira área de expansão urbana do município ocorreu no setor sudeste, quase totalmente circunscrita no bairro Itaim.

O período seguinte, entre 1993 e 2000, tem como consequência o crescimento das áreas supracitadas, principalmente nos bairros Bananal, São João e Pimentas. Houve tambén o surgimento de um importante núcleo populacional no bairro Invernada, que aparece como uma extensão da mancha no bairro Bananal ao norte do aeroporto, além de um núcleo esparso no bairro Mato das Cobras.

O terceiro período, entre 2000 e 2007, tem um ritmo de crescimento menos acelerado, tendo como elemento central a ampliação de áreas urbanas pré-existentes, sendo o mais relevante no bairro de Bom Sucesso, localizado no setor a oeste do aeroporto.

A análise dos pesos de evidência para o período, considerando as transições de Loteamento Irregular para Urbano Regular e de Campo/Capoeira para Urbano Regular permitem identificar a influência das variáveis espaciais na alocação das novas áreas urbanas.

As baixas declividades (até 8\%) chamam atenção por exercer influência positiva no primeiro período, entre 1986 e 1993, quando os terrenos planos estavam amplamente disponíveis para ocupação. Nos anos seguintes, é possível verificar uma ampliação das declividades que exercem peso positivo na alocação de novas áreas, podendo chegar aos 15\% de declividade.

As indústrias apresentam uma relação positiva para as novas áreas residenciais entre 1986 e 1993 até os 2.600 m, ao passo que nos períodos seguintes essa relação é fortemente negativa até os $1.000 \mathrm{~m}$ de distância, 
quando então passa a ser positiva. Essa mudança da relação da indústria com os novos assentamentos pode ter uma influência direta com a melhoria dos transportes como um todo ao longo das décadas de 1990 e 2000.

A análise dos pesos de evidência em função das vias estruturais, que englobam as principais vias para deslocamento no município, corroboram essa idéia. Também ali houve uma mudança na influência das vias na alocação de novas áreas residenciais. Entre 1986 e 1993 a influência desta variável é pouco relevante até os $1.600 \mathrm{~m}$, quando passa a ser essencialmente negativa. Porém, nos períodos seguintes, começa a haver uma transição, de forma que entre 1993 e 2000 a influência é positiva até os $100 \mathrm{~m}$ de distância para ser crescentemente negativa até os $1.300 \mathrm{~m}$, enquanto no período seguinte a influência das vias estruturais é negativa apenas até os $100 \mathrm{~m}$ de distância, sendo a partir daí crescentemente positiva.

Um dos aspectos importantes para ser destacado do crescimento de Guarulhos é o aumento da população. Para ter uma ideia do que representou este contingente populacional, é preciso verificar que o plano urbanístico para o período previa um total de 355.274 habitantes no final da década de 1980 . Porém, ao final desta década a população já estava em mais de 500 mil habitantes e em ritmo de crescimento.

De modo geral, as transições de campo/capoeira para urbano regular foram negativamente influenciados pela proximidade com o aeroporto nos três períodos analisados, ao passo que no caso as transições ocorridas sobre os loteamentos desocupados apresentaram uma influência positiva do aeroporto no período entre 1986 e 1993 e entre 2000 e 2007 . Tais diferenças provavelmente refletem a disposição das classes de origem em relação ao referido equipamento, que a uma disposição direta com o aeroporto.

A forte oferta de empregos diretos e indiretos pelo aeroporto, bem como o valor reduzido dos imóveis nas áreas mais próximas ao parque aeroportuária, tem uma influência positiva na atração dos contingentes que se dirigiram ao município de Guarulhos. O mapa de probabilidades de transição para o primeiro período apresentado na Figura 6.23 reforça fortemente essa afirmação. Ali é 
possível verificar a disposição dessas probabilidades ao redor do aeroporto de Guarulhos.

Esse crescimento envolveu habitações tipicamente horizontalizadas, frequentemente geminadas e sem quintais ou jardins significativos. Tais elementos espalharam-se rapidamente na paisagem urbana, sem que o município conseguisse atender as novas demandas por serviços básicos, como saneamento, energia elétrica e asfalto, para as quais a ausência foi mais marcante nos bairros afastados da região central de Guarulhos. Isso acabou gerando também a proliferação de favelas.

Um dos fatores de dispersão e fixação das camadas mais pobres da sociedade está associada à oferta de trabalho temporário e a existência de moradias, por uma vez que o vínculo empregatício cessa, o trabalhador tende a permanecer no local, ainda que em moradias precárias, dada a baixa mobilidade em função das condições financeiras (REIS, 2006).

Lasalvia (2006) entende que este processo tenha ocorrido em Guarulhos, principalmente em função das indústrias, que atraíram ao longo da década de 1970 um contingente de mão de obra pouco qualificada, mas à medida que a indústria se especializava, passava a ofertar empregos para profissionais mais qualificados, trazendo novos contingentes, que se somaram aos primeiros assentamentos.

Um dos principais problemas deste crescimento foi a incapacidade da prefeitura para fiscalizar adequadamente as construções que vinham sendo erguidas. Com isso o município de Guarulhos viu os loteamentos irregulares crescerem rapidamente, e já na década de 1980 o município ocupava a primeira posição dentre os municípios da RMSP em número absoluto de favelas.

Os mapeamentos realizados para o presente estudo só puderam mensurar as favelas com as características de cobertura apontadas na figura 5.4, ou seja, ficaram de fora loteamentos cuja irregularidade se constata pela inexistência da certidão do imóvel, inexistência do saneamento adequado ou pelos calçamentos inadequados. Ainda assim, é possível acompanhar o rápido crescimento delas no período analisado por meio destes mapas. 
Dentre as áreas classificadas como Urbano irregular, o período de maior expansão ocorreu entre 1986 e 1993, quando a classe saltou de 0,39 km² no primeiro ano para $1,57 \mathrm{~km}^{2} \mathrm{em} 1993$, com o surgimento de manchas nas proximidades das industrias ao sul e ao norte do aeroporto. Em 2000 atinge a marca de $1,95 \mathrm{~km}^{2}$ com o crescimento das áreas preexistentes. E por fim, se mantém praticamente estável em 2007, quando chega à marca de 1,97 km².

De acordo com as matrizes de transição, as favelas que surgiram na paisagem de Guarulhos entre 1986 e 1993 fixaram-se principalmente os Loteamentos desocupados, como resultado de um menor controle dessas áreas. Nos períodos seguintes, entre 1993 e 2000 e entre 2000 e 2007, a ocupação de favelas se deu principalmente sobre as classes campo/capoeira e industrias/galpão, respectivamente.

A análise dos pesos de evidência mostra que esta classe sofreu uma influência positiva nos terrenos de baixa declividade (até 10\%) nos dois primeiros períodos, ao passo que no período final, entre 2000 e 2007, a influência positiva é exercida até os terrenos mais íngremes, cerca de 30\% de declividade.

É importante destacar que uma das características desse tipo de ocupação é a condição dos terrenos, frequentemente associada a áreas de risco, seja por sua suscetibilidade a enchentes, quando localizados em áreas de baixa declividade, seja por sua suscetibilidade a escorregamentos, quando localizados em áreas com maior declividade.

É um problema que tem reflexos atuais no município. Segundo um boletim da prefeitura de Guarulhos (GUARULHOS, 2016), existem ainda 45 áreas de risco no município, o que afeta milhares de pessoas, principalmente nos períodos de chuva.

É importante notar que o aeroporto exerce um papel positivo nas transições de urbano irregular apenas no primeiro período, que compreende os primeiros anos após a sua inauguração. Lasalvia (2006) sustenta que o aeroporto concentra uma grande demanda de mão de obra em serviços o que tende a atrair mão de obra, o que acaba tendo reflexos também nas residências 
irregulares. Contudo, nos dois períodos seguintes o aeroporto deixa de exercer essa atração para esta classe.

No que se refere à economia do município, de acordo com dados apresentados por Lasalvia (2006), a evolução do cenário econômico de Guarulhos a partir da década de 1980 evidencia seu perfil industrial, destacandose o fato de apresentar um ritmo de crescimento ao longo de todo o período analisado.

Mesmo no caso da queda no número de empregos ocorrida no Brasil no final da década de 1980 e ao longo da década de 1990, como resultado de crises econômicas internas e da abertura dos portos para importação de produtos estrangeiros, o município de Guarulhos apresentou uma taxa de redução menor no número de empregos (21\%) em relação à taxa média para a Região Metropolitana de São Paulo (30\%), conforme estudo realizado por Figueiredo Ferraz (2003).

No mesmo estudo há a menção sobre o setor de serviços em Guarulhos, que cresceu mais rapidamente que o setor industrial ao longo das décadas de 1980 e 1990. Segundo Figueiredo Ferraz (2003) o número de estabelecimentos no setor de serviços passou de 387 em 1980 para 5.001 em 1999, ao passo que dentre os estabelecimentos comerciais o crescimento também foi elevado,

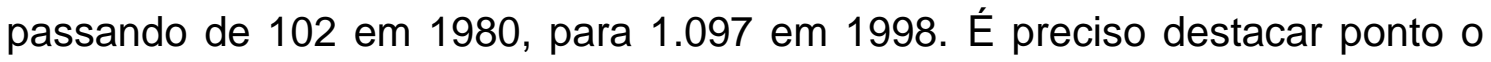
elevado crescimento das empresas relacionadas ao turismo no período, com crescimento de 500\% entre a década de 1980 e 1990.

Também é preciso destaque para o surgimento de atividades comerciais em atividades correlatas ao aeroporto, como as escolas de aviação, armazenamento, carga, descarga e logística, serviços de fornecimento de refeições, limpeza despacho e aduaneiros, e os serviços de transporte e remessa de bens. Os restaurantes que atendem aos trabalhadores de todas essas empresas e os fornecedores de itens diversos como papelaria e mercados, completam o quadro de elementos que justificam esse crescimento acelerado do setor de serviços. 
Por sua vez, o ritmo de crescimento das industrias foi menos elevado, passando de 23 em 1980 para $141 \mathrm{em}$ 1999. Isso fez com que o setor industrial tivesse uma menor participação na composição do valor adicionado do município. No entanto, isso não diminui a importância do setor industrial em Guarulhos, que a despeito das crises econômicas e das dificuldades da indústria brasileira em função da abertura econômica na década de 1990, continuou crescendo, como pode ser observado nos mapas de cobertura e uso da terra apresentados.

Neste sentido, um dado importante sobre a relação das industrias com o aeroporto após sua inauguração foi apresentada por Kobashi (apud Lasalvia, 2006), e se refere à tipologia dos empreendimentos industriais existentes em Guarulhos, que puderam de alguma forma se utilizar das rotas áreas para realizar importações de Máquinas e Material Elétrico, Reatores e Caldeiras, Produtos Farmacêuticos e Instrumentos Óticos, bem como a exportação dos mesmos itens e Produtos Químicos Orgânicos.

A conclusão a que chegou o estudo apresentado, é que o aeroporto reforçou a ampliação de alguns segmentos já existentes, bem como favoreceu 0 surgimento de novos segmentos, principalmente em função do crescimento de industrias que geram produtos com alto valor agregado.

Em relação às áreas ocupadas por industrias ou galpões, é possível verificar que a quase a totalidade do crescimento desta classe ocorre no primeiro período, entre 1986 e 1993, quando passa 4,82 km² para $17,78 \mathrm{~km}^{2}$, um crescimento de $269 \%$. Esse rápido crescimento é resultado da desindustrialização de São Paulo, ocorrida ao longo da década de 1980, e é consoante à chegada das grandes industrias em Guarulhos, conforme apontou Lasalvia (2006).

Nos dois períodos posteriores a taxa de crescimento decai rapidamente e se estabiliza em valores próximos aos 10\% tanto no período entre 1993 e 2000, como entre 2000 e 2007.

Tais movimentos localizam-se, de modo geral, no entorno da rodovia Presidente Dutra, como pode ser observado na figura 6.7 a seguir. Os bairros 
mais afetados na fase de maior crescimento foram Itapegica, no sudoeste de Guarulhos, Taboão e Cumbica à oeste e sul do aeroporto de Guarulhos, respectivamente, e Bom Sucesso, Sadokim, Água Chata e Aracília no extremo leste do município. Os dois períodos posteriores foram responsáveis pelo crescimento das áreas previamente ocupadas por industrias no município. Essas transições podem ser visualizadas na Figura 6.41, a seguir.

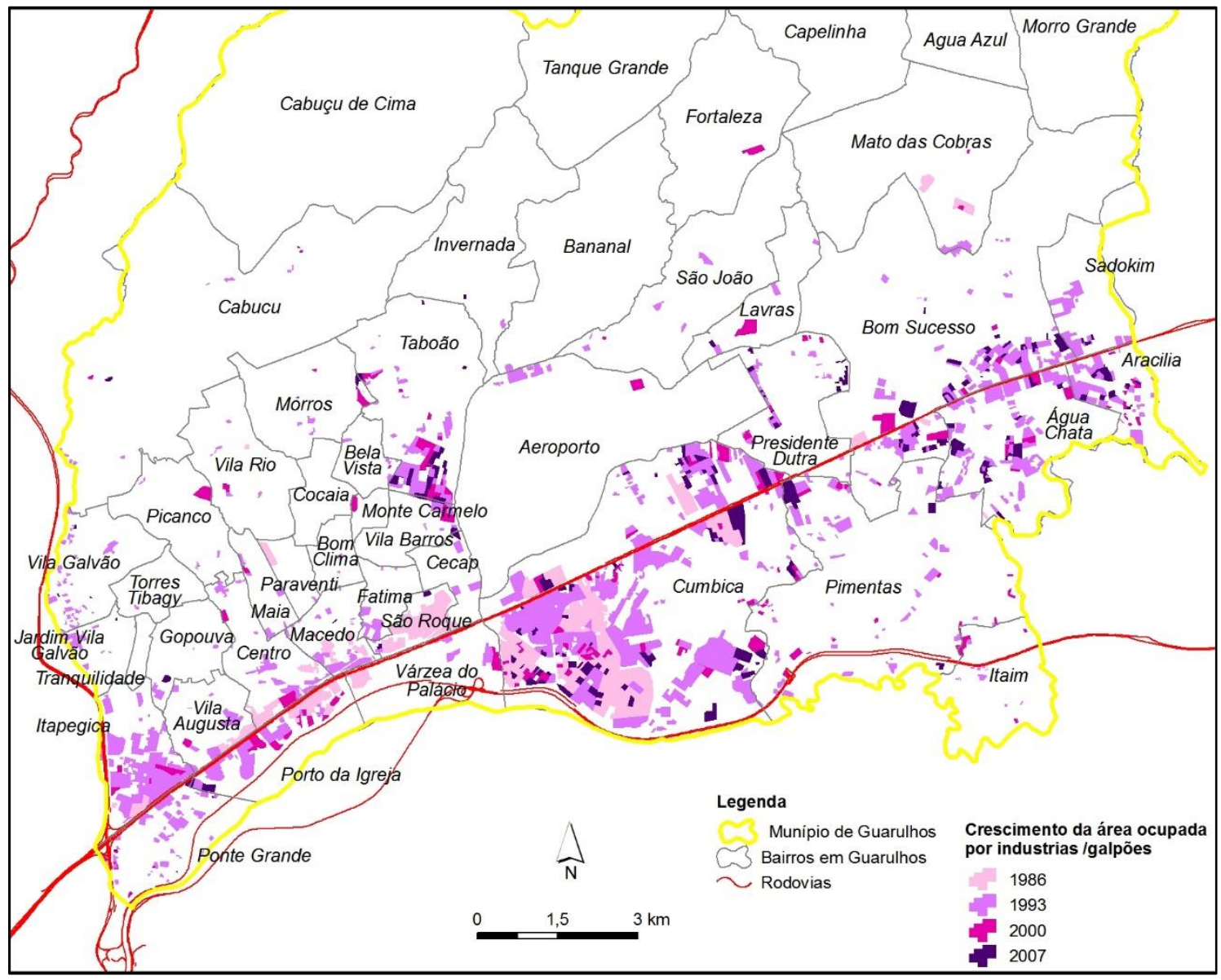

Figura 6.41 - Crescimento da indústria/ Galpão no município de Guarulhos

Vale destacar que tais crescimentos se desenvolveram principalmente sobre áreas previamente ocupadas por campos ou capoeiras, sendo esta a classe que mais rapidamente diminuiu, passando de $38,4 \mathrm{~km}^{2}$ em 1986 para 29,6 km² em 1993, 19,13 km³ em 2000 e 14,8 em 2007.

A análise das matrizes de transição para os três períodos permite verificar que em geral as transições ocorrem sobre os loteamentos desocupados, tendo sido mais representativo no período entre 1986 e 1993, quando a transição 
ocorreu sobre $23,8 \%$ dos loteamentos desocupados. Nos demais períodos 0 percentual se estabilizou em torno dos $10 \%$.

É preciso destacar que a origem em outras classes para a classe de industrias e galpões foi significativa apenas no primeiro período, quando $14,5 \%$ das áreas classificadas como campo e capoeira em 1986 passaram a indústria/galpão em 1993.

Além disso, a Tabela 6.4 permite verificar dois aspectos sobre a industrialização do município. Um deles é o fato que houve um pequeno crescimento industrial dentro da malha residencial do município, acarretando 0,45\% das mudanças ocorridas no período, com a transição de urbano regular para indústria/galpão. Outro aspecto relevante, é que a despeito da crescente industrialização no período analisado, parte das áreas ocupadas com indústrias/ galpões em 1986 foram desativadas, dando lugar a loteamentos desocupados $(6,83 \%)$.

No que se refere à observância dos pesos de evidência para esta transição é preciso levantar algumas questões importantes.

Normalmente a topografia é um fator determinante para alocação das industrias, e isso se refletiu muito bem no cálculo dos pesos de evidência. Nos três períodos analisados foi possível verificar a forte dependência da declividade para alocação das industrias, conforme pode ser visto na Figura 6.34, no qual se nota uma influência positiva de declividades até os 4,5\%, 7\% e $8 \%$ no primeiro, segundo e terceiro período respectivamente.

A distância às áreas urbanas também se torna um fator determinanteem função dos planos diretores que determinam a distância às manchas ocupadas por residências. Nos três períodos verificou-se uma influência negativa até os 280 metros, a partir de onde passa a haver uma influência crescentemente positiva, na medida em que se afasta, conforme a figura 6.35.

Por outro lado, o ponto preferencial para a ocupação por industrias e galpões é a proximidade com vias de acesso ao município. Também neste aspecto o cálculo dos pesos de evidência se mostrou particularmente acurado, revelando uma influência positiva em função da proximidade com as vias 
estruturais, que dão mobilidade dentro do município de Guarulhos e acesso aos municípios limítrofes, e também com as vias estruturais e macrometropolitanas, que dão acesso ao eixo Rio-São Paulo, tal como pode ser observado nas Figuras 6.32 e 6.33 , respectivamente.

As áreas com produção agrícola no município são relativamente pequenas, sendo que o IBGE classificou todas as áreas do município como áreas urbanas, o que indica que não existe nenhum setor censitário com quantidade suficiente de domicílios em situação rural. Em termos de área, a produção agrícola ocupava 3,68 km² em 1986, cresceu para 5 km² em 1993 e decresceu continuamente nos anos seguintes, passando a 4,8 km² em 2000 e $4,7 \mathrm{~km}^{2}$ em 2007.

No processo de mapeamento, as áreas vegetadas foram classificadas como mata. Todo o município de Guarulhos está inserido no bioma da Mata Atlântica e sofreu pequenas supressões ao longo dos anos observados, mantendo-se praticamente estável ao longo de 20 anos.

Essa situação só foi possível em função da alta declividade onde estão localizadas as matas e da extensão das áreas protegidas do Parque Estadual da Cantareira e do Parque Estadual de Itaberaba, que juntos agregam quase a totalidade do setor norte de Guarulhos.

É importante destacar que boa parte desta vegetação é secundária, que se desenvolveu após o século XIX em função das necessidades de abastecimento da cidade de Guarulhos. 


\subsection{Resultados da Modelagem}

A etapa de validação implementada no Dinâmica-EGO utiliza um algoritmo para gerar índices de similaridade baseados em uma janela de análise de pixels com tamanhos variados entre $5 \times 5$ e $11 \times 11$. Tais métodos para avaliação das simulações foram aplicados nos mapas simulados de 1993, 2000 e 2007.

Os resultados das validações realizadas para os três períodos são apresentados nas Tabelas 6.7, 6.8 e 6.9, ao passo que as comparações entre os mapas reais e os mapas simulados são apresentadas nas figuras $6.42,6.43$ e 6.44 .

\begin{tabular}{ccc}
$\begin{array}{c}\text { Tamanho da } \\
\text { Janela }\end{array}$ & $\begin{array}{c}\text { Similaridades } \\
\text { Mínimas }\end{array}$ & $\begin{array}{c}\text { Similaridades } \\
\text { Máximas }\end{array}$ \\
\hline 1 & 0,367 & 0,370 \\
\hline 3 & 0,382 & 0,400 \\
\hline 5 & 0,393 & 0,418 \\
\hline 7 & 0,404 & 0,434 \\
\hline 9 & 0,415 & 0,448 \\
\hline 11 & 0,426 & 0,461
\end{tabular}

Tabela 6.7 - Decaimento exponencial da simulação para o ano de 1993.

\begin{tabular}{ccc}
$\begin{array}{c}\text { Tamanho da } \\
\text { Janela }\end{array}$ & $\begin{array}{c}\text { Similaridades } \\
\text { Mínimas }\end{array}$ & $\begin{array}{c}\text { Similaridades } \\
\text { Máximas }\end{array}$ \\
\hline 1 & 0,392 & 0,392 \\
\hline 3 & 0,418 & 0,443 \\
\hline 5 & 0,439 & 0,471 \\
\hline 7 & 0,456 & 0,493 \\
\hline 9 & 0,471 & 0,511 \\
\hline 11 & 0,484 & 0,526
\end{tabular}

Tabela 6.8 - Decaimento exponencial da simulação para o ano de 2000. 


\begin{tabular}{ccc}
$\begin{array}{c}\text { Tamanho da } \\
\text { Janela }\end{array}$ & $\begin{array}{c}\text { Similaridades } \\
\text { Mínimas }\end{array}$ & $\begin{array}{c}\text { Similaridades } \\
\text { Máximas }\end{array}$ \\
\hline 1 & 0,284 & 0,285 \\
\hline 3 & 0,301 & 0,321 \\
\hline 5 & 0,316 & 0,340 \\
\hline 7 & 0,329 & 0,354 \\
\hline 9 & 0,342 & 0,366 \\
\hline 11 & 0,354 & 0,376
\end{tabular}

Tabela 6.9 - Decaimento exponencial da simulação para o ano de 2007.

De modo geral, os mapas simulados apresentaram bons resultados tanto pela validação de similaridade exponencial, bem como na comparação com o mapeamento realizado.

No caso do mapa simulado para o ano de 1993, na Figura 6.42, é possível verificar que existem duas áreas nas quais as manchas tiveram um resultado menos adequado na simulação. Na quadrícula $\mathrm{A} 6$ há um núcleo habitacional isolado no ano de 1986 que sofreu expansão e se dissolveu à mancha urbana principal no ano de 1993. No mapa simulado para 1993, contudo, é possível verificar que este núcleo urbano permaneceu isolado. Por outro lado, na quadricula F6 houve uma concentração muito grande da classe industrial margeando a rodovia. Também nessa área ficaram as novas manchas de loteamentos desocupados.

Por sua vez, a simulação para o ano de 2000, na Figura 6.43, apresentou resultados melhores de modo geral, inclusive atestado em coeficientes mais elevados na análise por decaimento exponencial. De fato, as manchas visualmente mais inadequadas estão concentradas na quadricula B5, ao redor da mancha de áreas urbanas regulares, e nas quadrículas C6 e E6, onde o crescimento das áreas industriais foi superior ao esperado.

A simulação do ano de 2007, na Figura 6.44, responde por modificações relativamente pequenas na paisagem, o que gerou mapas visualmente muito coerentes, resultando em diferenças mais marcantes ao sul do aeroporto, no quadrante E6. 


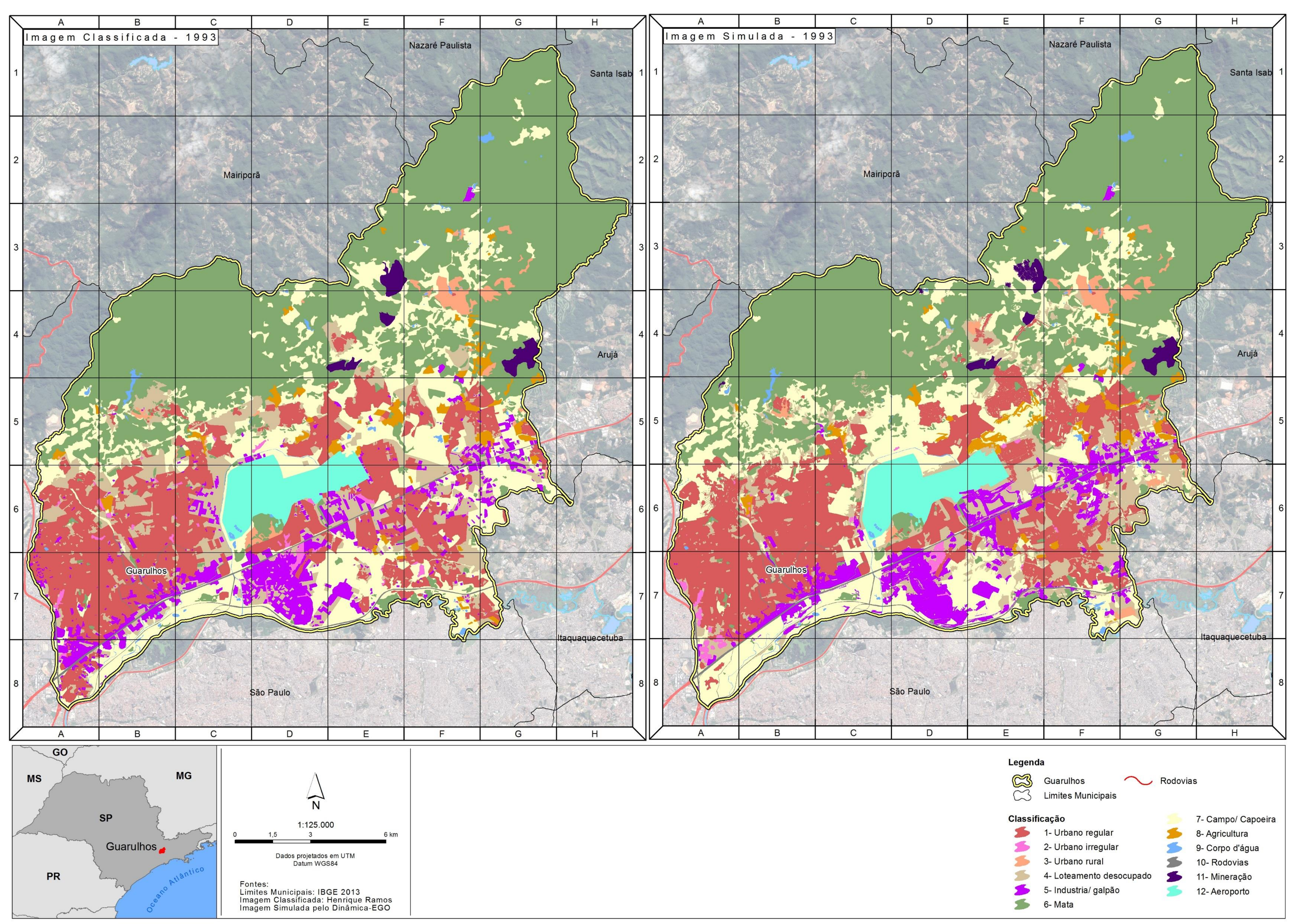

Figura 6.42 - Comparação entre o mapeamento realizado para 1993 e a simulação para o ano de 1993 


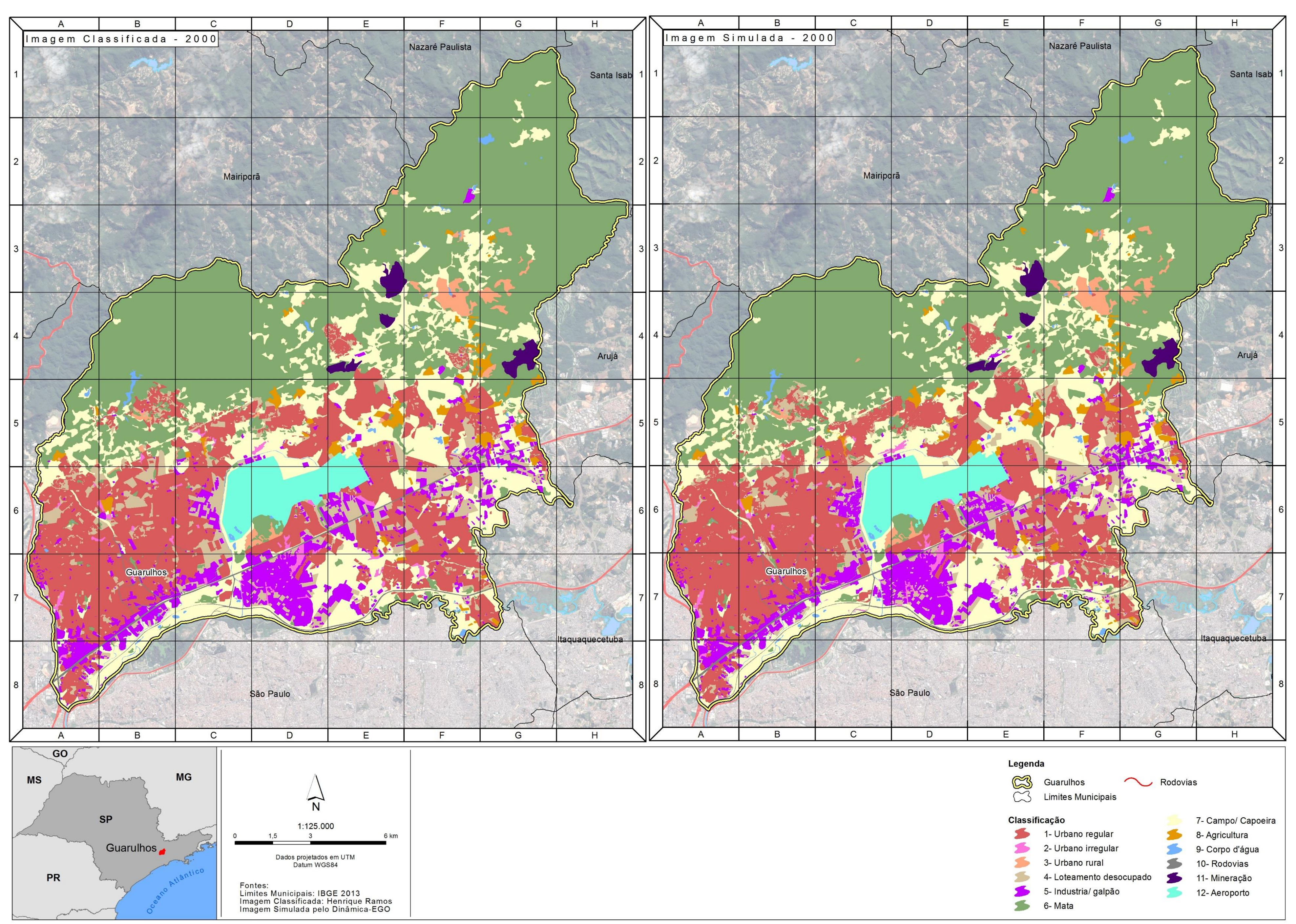

Figura 6.43 - Comparação entre o mapeamento realizado para 2000 e a simulação para o ano de 2000 


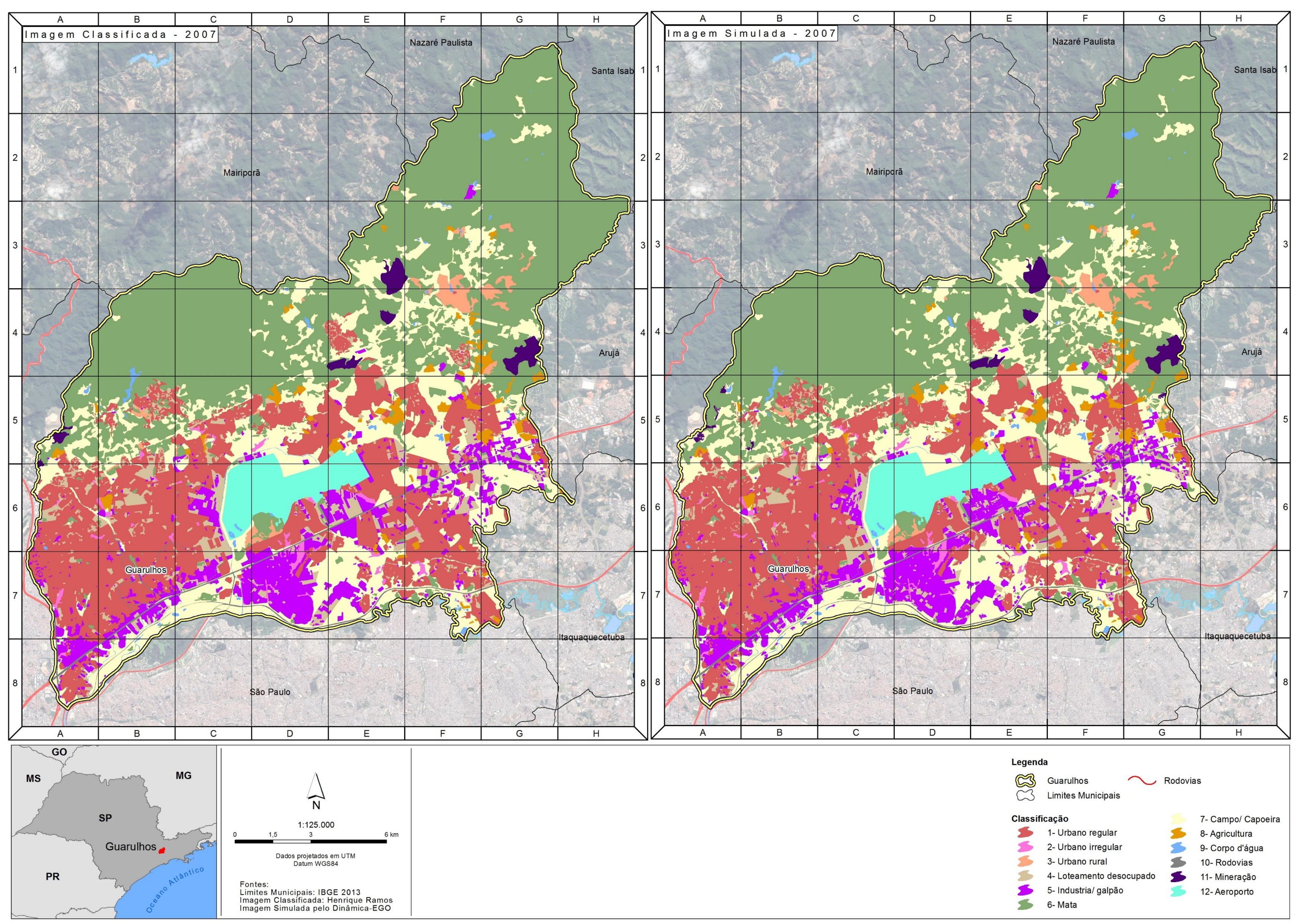

Figura 6.44 - Comparação entre o mapeamento realizado para 2007 e a simulação para o ano de 2007 


\section{Considerações Finais}

A pesquisa permitiu investigar as relações entre as vias de acesso ao município de Guarulhos e o desenvolvimento e crescimento urbano, principalmente no que se refere às manchas residenciais e industriais existentes no município.

No desenvolvimento da pesquisa, foi possível a utilização de imagens orbitais de alta resolução para gerar um mapa de referência, no nosso caso o mapa de cobertura e uso da terra de 2007 e, com isso usar ele como base para traçar os mapas dos demais anos, onde só estavam disponíveis as imagens aéreas sem metadados. Permitindo a integração de fotografias antigas com bases mais modernas oriundas de satélite ou fotografias ortorretificadas.

Isso abre a possibilidade de ampliar o estudo para a década de 1950, uma vez que no decorrer do estudo, foram inventariadas as imagens para os anos de 1952, 1961 e 1972, disponíveis por meio de solicitação formal.

O uso de imagens de alta resolução possibilitou a identificação de 12 classes de cobertura e uso da terra, o que permitiu destacar classes de grande importância em estudos urbanos, mas que possuem abrangência reduzida, tais como pequenas indústrias e galpões entremeados à mancha de unidades habitacionais, bem como as manchas ocupadas por favelas. Além disso, a escala dos mapas, fixadas em 1:10.000, permitiu que trabalhássemos com um grid de detalhe (pixel de $25 \mathrm{~m}^{2}$ ).

É importante destacar que a realização manual dos mapeamentos resultou em um índice de Kappa elevado e em um mapa multitemporal, no qual os polígonos se sobrepõem mutuamente. Isso resultou em menor esforço para corrigir os mapas matriciais por tabulação cruzada.

A seleção das variáveis explicativas buscou um conjunto de dados disponível para todos os períodos analisados. Embora isso tenha excluído muitos dados importantes que poderiam ter sido utilizados para o último período, entre 2000 e 2007, também permitiu avaliar a influência das variáveis na 
dinâmica da paisagem ao longo do tempo, bem como as flutuações das probabilidades nos referidos mapas.

De modo geral, foi possível verificar que mesmo com um número limitado de variáveis, restritas aos aspectos geomorfológicos da paisagem, à disposição das vias de locomoção internas e vias de acesso ao município de Guarulhos e distância das manchas urbanas e industriais, foi possível extrair um conjunto bastante aderente às informações disponíveis para o município de Guarulhos.

Neste aspecto destaca-se particularmente a influência que as vias estruturais e macrometropolitanas tiveram na dinâmica das áreas ocupadas por industrias e galpões, resultando que tais elementos foram mais importantes que o próprio aeroporto. Na mesma linha de raciocínio, a análise conjunta dos mapas de cobertura e uso da terra, matrizes de transição, mapas de probabilidade e pesos de evidencia, mostraram que o aeroporto exerceu uma influência positiva nos primeiros anos após sua inauguração, e afastou a transição de urbano regular nos quinze anos seguintes.

No que se refere às simulações, pudemos constatar que o modelo conseguiu acompanhar os principais eixos de crescimento urbano e industrial, fato que pode ser melhor constatado no primeiro período, quando as alterações foram mais significativas.

No que se refere às simulações, pudemos constatar que de um modo geral os modelos conseguiram acompanhar os principais eixos de crescimento do município, tendo um resultado particularmente eficaz na alocação das novas áreas ocupadas por industrias e galpões. É preciso reforçar que foi uma das classes cujos resultados no cálculo dos pesos de evidência que mais se adequaram ao que esperávamos em função das leituras de pesquisas realizadas no local. Da mesma forma, embora seja possível estimar os principais vetores de crescimento das manchas de urbano regular, essa classe teve um descolamento razoável em relação ao mapa real, e isso pode ser um resultado direto da impossibilidade de modelar o preço dos imóveis e terreno em Guarulhos nos referidos anos. 
Quanto aos erros, parte dos problemas da alocação de áreas que tiveram crescimento elevado em áreas distintas do mapa, como por exemplo a classe de urbano regular e o loteamento desocupado entre os anos de 1986 e 1993, tem a ver com o processo estocástico de alocação das transições sobre as manchas de probabilidade e devido à aleatoriedade é possível obter mapas mais acurados ainda que rodando o modelo sem alteração dos parâmetros.

Período de tempo com menores quantidades globais de transições, se mostraram mais difíceis de serem modelados. Em especial o período entre 2000 e 2007, cuja validação por decaimento exponencial mostrou um desempenho menos eficaz que o encontrado nos demais anos. Parte disso ocorre devido à interseção das pequenas transições com um grupo de variáveis diverso, o que gerou mapas de probabilidade de transição muito distintas em relação ao esperado. A despeito desta consideração, visualmente é possível verificar que a dispersão das manchas na paisagem não seguiu nenhuma direção incomum, limitando-se onde era o esperado.

A manipulação de dados básicos do município de Guarulhos junto com os mapas obtidos por meio de classificação manual permitiu identificar as transições ocorridas no município e a influência de cada elemento geográfico em cada uma das transições, permitindo obter respostas aos mecanismos dinâmicos da cidade.

A obtenção de dados mais acurados sobre o município, pode ampliar as possibilidades de obter melhores resultados, como por exemplo, plantas que indiquem os valores dos imóveis ou terrenos, ou a integração de simulações com variáveis econômicas, podem gerar simulações com melhores resultados. 


\section{Referências Bibliográficas}

AKIN, A.; SUNAR, F.; BERBEROGLU, S.; Urban change analysis and future growth of Istanbul. Environmental Monitoring and Assessment, 2015.

ALJOUFIE, M.; ZUIDGEEST, M.; BRUSSEL, M.; VLIET, J.; MAARSEVEEN, M.; A Cellular Automata-Based Land Use and Transport Interaction Model Applied to Jeddah, Saudi Arabia. Landscape and Urban Planning, n 112, pag 89-99, 2013.

ALMEIDA, C.M.; Modelagem da dinâmica espacial como uma ferramenta auxiliar ao planejamento: simulação de mudanças de uso da terra em áreas urbanas para as cidades de Bauru e Piracicaba-SP. 351p. Tese (Doutorado) - Instituto Nacional de Pesquisas Espaciais, INPE, São José dos Campos, SP. 2004.

ALMEIDA, C. M; MONTEIRO, M. V.; CÂMARA, G.; 2003. Modelos de Dinâmica Urbana: Conceitos, Derivação de Relações, Calibração, Exemplos. In Módulo 6 do Curso Modelagem Ambiental e Modelos Dinâmicos de Uso e Cobertura do Solo oferecido durante XI Simpósio Brasileiro de Sensoriamento Remoto, 2003a. Disponível em http:/www.dpi.inpe.br/cursos/ tutoriais/modelagem/Cap3_Modelos_Urbanos_Versao_Nova.pdf.

ALMEIDA, C. M.; BATTY, M.; CÂMARA, G.; CERQUEIRA, G. C.; MONTEIRO, A. M. V.; SOARES-FILHO, B. S.; PENNACHIN, C. L.; Stochastic cellular automata modelling of urban land use dynamics: empirical development and estimation. Computers, Environment and Urban Systems, vol. 27, p.481$509,2003 \mathrm{~b}$.

ALMEIDA, C. M; MONTEIRO, M. V.; CÂMARA, G.; SOARES-FILHO, B. S.; CERQUEIRA, G. C.; PENNACHIN, C. L.; BATTY, M.; GIS and remote sensing as tools for the simulation of urban land-use change. International Journal of Remote Sensing, vol. 26, ㄲo4, fev, p. 759-774, 2005.

ALMEIDA, C. M.; CAMARA, G.; MONTEIRO, . M. V.; SOARES-FILHO, B. S. S.; CERQUEIRA, G. C.; Modelos Celulares de Dinâmicas Espaço-Temporais: Aplicações em Estudos Urbanísticos. In: MEIRELLES, M. S. P.; CÂMARA, G.; 
ALMEIDA, C. M. (Ed.). Geomática: modelos e aplicações ambientais. 2007.

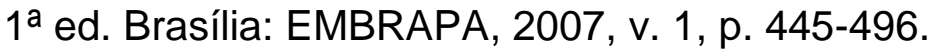

ALMEIDA, F. F. M.; O Cráton do São Francisco. Revista Brasileira de Geociências, 7:349-364, 1977.

ANDERSON, J.R; HARDY, E.E.; ROACH, J. T.; WITMER, R.E. Sistema de classificação de uso da terra e do revestimento do solo para utilização com dados de sensores remotos. Tradução de Harold Strang. Rio de Janeiro: IBGE, $78 p, 1979$.

ANTUNES, A. F. B.; LINGNAU, C. Uso dos Índices de Acurácia para Avaliação de Mapas temáticos obtidos por meios de classificação digital. In: III Congresso e Feira para Usuário de geoprocessamento, Curitiba, III Congresso e Feira para Usuário de geoprocessamento, Curitiba: Sagres, 1997.

BASSE, R.M.; A constrained cellular automata model to simulate the potential effects of high-speed train stations on land-use dynamics in transborder, Journal of Transport Geography, 32, p. 23-37, 2013.

BATTY, M.; COUCLELIS, H.; EICHEN, M.; Urban Systems As Cellular Automata, Environmental and Planning B, v.24, p. 159-164, 1997.

BONHAM-CARTER, G. Geographic information systems for geoscientists: modelling with GIS. New York: Pergamon, 1994. 414p.

BURROUGH, P.A.; Principles Of Geographical Information Systems For Land Resources Assessment. Oxford: Claredon Press, 194p, 1998.

BÜTTNER, G.; FERANEC, J.; JAFFRAIN, G.; Corine Land Cover Update 2000: Technical Guide. EEA Technical Report n.․ 89. EEA, Copenhagen. 2002.

CÂMARA, G.; DAVIS, C.; MONTEIRO, A.M.V.; Introdução à Ciência da Geoinformação. INPE: São José dos Campos, 2003. Disponível em http://www.dpi.inpe.br/gilberto/livro/introd/

CHADID, M.A.; DÁVALOS, L.M.; MOLINA, J.; ARMENTERAS, D.; A Bayesian Spatial Model Highlights Distinct Dynamics in Deforestation from Coca and 
Pastures in an Andean Biodiversity Hotspot, Forests, v6, Issue 11, pag 38283846, 2015.

CHORLEY, R.; J., HAGGETT, P.; Modelos Físicos e de Informação em Geografia. São Paulo: Edusp, 1975.

CHRISTOFOLETTI, A. Modelagem de Sistemas Ambientais. São Paulo: Edgar Blücher, 1999.

CHWIF, L; MEDINA, A. C. Modelagem e simulação de eventos discretos: teoria e aplicações. 1. Ed. São Paulo: Bravarte, 2006. v. 1, 255p

COHEN, J.; A coefficient of agreement for nominal scales. Educational and Psychological Measurement 20, 37-46, 1960.

CONGALTON, R. G.; A Review of assessing the accuracy of classifications of remotely sensed data. Remote Sensing Environment, v. 37, p. 35-46, 1991.

COUCLELIS, $\mathrm{H}_{\text {.; }}$ From cellular automata to urban models: new principles for model development and implementation. Environment and Planning B, v.24, pp. 165-174, 1997.

CRÓSTA, A. P. Processamento digital de imagens de sensoriamento remoto. Campinas: Unicamp, 1993.

ECHENIQUE, M.; Models: A discussion. Cambridge: University of Cambridge Dept. of Architecture, 1968.

FIGUEIREDO FERRAZ. Estudo de Impacto Ambiental - EIA-RIMA Para o Aeroporto Internacional de São Paulo / Guarulhos. São Paulo, 2003

GALINARI, R. Economias de Aglomeração no Brasil: Evidências a Partir da Concentração Industrial Paulista. CEPEPLAR, UFMG, 2007.

GOOGLE; Guarulhos - Google Maps. 2016. Consultado em Maio de 2016, em https://goo.gl/maps/5BvcSo3xipH2. 
GUAN, D., LI, H., INOHAE, T., SU, W.; NAGAIE, T.; HOKAO, K.. Modelling urban land use change by the integration of cellular automaton and Markov model. Ecological Modelling, v. 222, n. 20-22, p. 3761- 3772, 2011.

GUARULHOS, Portal de Geoprocessamento, 2008, disponível em http://webgeo.guarulhos.sp.gov.br/index2.php

GUARULHOS, Prefeitura reduz quantidade de áreas de risco na cidade, Boletim da Prefeitura, publicado em Setembro, 2016, disponível em http://www.guarulhos.sp.gov.br/municipal-de-defesa-civil/conteudo/prefeiturareduz-quantidade -de-\%C3\%A1 reas-de-risco-na-cidade

IBGE - INSTITUTO BRASILEIRO DE GEOGRAFIA E ESTATÍSTICA. 2006. Manual Técnico de Uso da Terra. $2^{\text {a }}$ ed. Rio de Janeiro, n. 7, 2006.

Cartas Topográficas. Rio de Janeiro, 1980.

Censo Demográfico 1990. Rio de Janeiro, 1991.

Censo Demográfico 2000. Rio de Janeiro, 2001.

Censo Demográfico 2010. Rio de Janeiro, 2011.

Malhas Digitais do Brasil em formato SHAPE. Rio de Janeiro, 2013.

JENSEN, J. R. Sensoriamento Remoto do Ambiente: uma perspectiva em Recursos Terrestres. Traduação de J. C. N. Epiphanio. São José dos Campos, SP: Parênteses, 2009. 598 p. (Prentice Hall Series in Geographic Information Sciennce) Tradução de: Remote Sensing of the environment: na earth resource perspective.

KAWASHIMA, R. S. Proposta De Modelagem Da Dinâmica Da Paisagem A Partir De Imagens De Satélite E Dados De Infraestrutura De Transportes E Da Atividade Portuária De Santos, 192p. Dissertação (Mestrado). Escola Politécnica - Departamento de Transportes - USP, São Paulo, 2015. 
LANDIS, J. R.; KOCH, G. G. The measurement of observer agreement for categoriacal data. Biometrics, v. 33, p. 159-174, 1977.

LASALVIA, L. A Cidade de Guarulhos e o Aeroporto. Dissertação (Mestrado), Faculdade de Arquitetura e Urbanismo - USP, São Paulo, 2006.

LANGENBUCH, J. R. A Estruturação da Grande São Paulo.Rio de Janeiro: IBGE, 1971.

LIMA T.C.; GUILLEN-LIMA C.M.; OLIVEIRA M.S.; SOARES-FILHO B.S. DINAMICA EGO e Land Change Modeler para simulação de desmatamento na Amazônia brasileira: análise comparativa. In: Anais do XVI Simpósio Brasileiro de Sensoriamento Remoto, Foz do Iguaçu: INPE, p. 6379-6386. 2013.

LIU, Y. Modelling urban development with geographical information systems and cellular automata. Boca Raton: Taylor \& Francis, 2009. 188 p.

LONGLEY, P.A.; GOODCHILD, M.F.; MAGUIRE, D.J.; RHIND, D.W.; Sistemas e Ciência da Informação Geográfica, São Paulo: Editora Bookman, 2011, 560 p.

LOPES, S. B. Uma Ferramenta para Planejamento da Mobilidade Sustentável com Base em Modelo de Uso do Solo e Transportes. Tese (Doutorado), Escola de Engenharia de São Carlos, São Carlos, 200p, 2010.

MALEK, Z.; BOERBOOM, L.; GLADE, T. Future Forest Cover Change Scenarios with Implications for Landslide Risk: An Example from Buzau Subcarpathians, Romania. Environmental Management. 2015.

MARQUES, E.; REQUENA, C.; O Centro Voltou a Crescer? Trajetórias Demográficas e Heterogeneidade na São Paulo dos Anos 2000, São Paulo: Novos Estudos, ㄲo95, Março, 2013.

MAS, J.F.; KOLB, M.; HOUET, T.; PARGELOW, M.; OLMEDO, M.T.C.; Una Comparación de Programas de Modelación de Cambios de Cobertura / Uso do Solo, Anais do Simposio Brasileiro de Sensoriamento Remoto, Curitiba, pag. 5801-5808, 2014. 
MEYER, R. M. P.; GROSTEIN, M. D.; BIDERMAN, C. São Paulo Metrópole. São Paulo. Edusp, 2004.

MMA - MINISTÉRIO DO MEIO AMBIENTE. Malha de Unidades de Conservação no Brasil, 2012.

MONBEIG, P. Pioneiros e Fazendeiros de São Paulo. Editora Hucitec, São Paulo, 392p., 1998.

MONTEIRO C.L.S. Proposta de Classificação do Uso e Cobertura da Terra e Sua Representação Cartográfica na Escala 1:10.000. 128p. Dissertação (Mestrado). Escola Engenharia Civil - UFSC, Santa Catarina, 2008.

NIMER, E.; Climatologia do Brasil. Instituto Brasileiro de Geografia e Estatística, Rio de Janeiro, RJ;, 1989. 421p.

NOVAES, A. G.; Modelos em Planejamento Urbano, Regional e de Transportes. São Paulo: Editora Edgard Blücher, 1981. 290p.

OLIVEIRA, A. M. S.; ANDRADE, M.R.M.; SATO, S.E.; QUEIROZ, W.; Bases Geoambientais para um Sistema de Informações Ambientais do Município de Guarulhos. Guarulhos: Laboratório de Geoprocessamento da Universidade Guarulhos, 2009. 178 p.

OMRANI, H.; CHARIF, O.; GERBER, P.; BÓDIS, K.; BASSE, R.M.; Simulation of Land-Use Change Using Cellular Automata and Artificial Neural Network. CEPS/INSTEAD, Italy. 2012.

ONU - Organização das Nações Unidas. Estado de Las Ciudades de America Latina Y el Caribe - Rumbo a una nueva transición urbana. ONU-Habitat, Mexico. 2012.

ONU - Organização das Nações Unidas. World Urbanization Prospects - The 2014 Revision. United Nations, New York, 2014.

PACHECO, E.; Alteração das Acessibilidades e Dinâmicas Territoriais na Região Norte: expectativas, intervenções e resultantes. Tese (Doutorado). Faculdade de Letras da Universidade do Porto, Porto, Portugal, 2001. 
PEDROSA, B.M.; CÂMARA, G.; Modelagem Dinâmica e Sistemas de Informações Geográficas in MEIRELLES, M.S.P., CAMARA,G., ALMEIDA, C.M. Geomatica - Modelos e Aplicações Ambientais, Embrapa: Brasilia, 2007

PRADO, F.A.; GALO, M.L.B.T.; Desenvolvimento De Um Sistema Hierárquico De Classificação Com Aplicação Baseada Em Abordagem Fuzzy. Boletim de Ciências Geodésicas, Seção de Artigos, Curitiba, V16, n2, p. 309-331, 2010.

REIS, N. G.; Notas sobre urbanização dispersa e novas formas de tecido urbano. São Paulo: Via das Artes, $1^{\circ}$ edição, 2006.

ROMÃO, J.G.; NORONHA, A.V.; Edição histórica comemorativa do I Centenário de Emancipação Política de Guarulhos (1880-1980). Homenagem da Prefeitura Municipal de Guarulhos e da Academia Guarulhense de Letras, 1980. São Paulo, 2000, Apud LASALVIA, L. A Cidade de Guarulhos e o Aeroporto. Dissertação (Mestrado), Faculdade de Arquitetura e Urbanismo - USP, São Paulo, 2006.

ROSS, J. L. S.; Mapa Geomorfológico do Estado de São Paulo. Escala 1:500.000. São Paulo: FFLCH/USP-IPT-FAPESP, 2006.

SANTOS, M. A.; Urbanização Brasileira. Editora Edusp, São Paulo, 174p., 1993.

SANTOS, R. R. Aeroportos: Do Campo de Aviação à Área Terminal. 1985.

SEADE - Fundação Sistema Estadual de Análise de Dados - FUNDAÇÃO SEADE, Índice Paulista de Vulnerabilidade Social, 2010.

SILVA, B. A. Aeroportos e Desenvolvimento. INCAER, Rio de Janeiro,1991.

SKLAR, F.H.; COSTANZA, R.; The development of dynamic spatial models for landscape ecology: a review and prognosis. In: TURNER, G.M., GARDNER, R.H. (Eds.), Quantitative Methods in Landscape Ecology: The Analyses and Interpretation of Landscape Heterogeneity. New York: Springer, 1990. p. 239-288. 
SOARES-FILHO, B. S.; CERQUEIRA, G. C.; PENNACHIN, C. L. DINAMICA- A stochastic cellular automata model designed to simulate the landscape dynamics in an Amazonian colonization frontier. Ecological Modelling, v.154, p. 217- 235. 2002.

SOARES-FILHO, B.S.; RODRIGUES, H.O.; COSTA, W.L.; Tradução de LIMA, L.S.; Modelagem Dinâmica Ambiental com Dinâmica EGO. Centro de Sensoriamento Remoto. Universidade Federal de Minas Geral, Belo Horizonte, MG. 2009.

SOUZA, C.D.R.; D'AGOSTO, M.A.; Modelo de quatro etapas aplicado ao planejamento de transporte de carga, Journal of Transport Literature, V.7, n.2, p207-234, 2013

STAN, K.; SANCHEZ-AZOFEIFA, A.; ESPÍRITO-SANTO, M.; Portillo-Quintero C, Simulating Deforestation in Minas Gerais, Brazil, under Changing Government Policies and Socioeconomic Conditions.PLOS ONE. 2015.

SUAREZ, A. F.; CANDEIAS, A. L. B.; Modelagem Dinâmica Para 0 Uso Cobertura Do Solo Na Mata Atlântica No Município De Maragogipe, BA. RBC. Revista Brasileira de Cartografia (Online), v. 66, p. 953-981, 2014.

TASM - Transport Appraisal and Strategic Modelling. Land Use/ Transpor Interaction Models. Supplementary Guidance, London, UK. 2014. Disponível em https://www.gov.uk/government/uploads/system/uploads/attachment data/ file/427140/webtag-tag-supplementary-luti-models.pdf.

TAUTENBÖCK, H.; ESCH, T.; FELBIER, A.; WIESNER, M.; ROTH, A.; DECH, S.; Monitoring Urbanization in Mega Cities from Space. Remote Sensing of Environment, n 117, p. 162-176, 2012.

VERBURG, P.H., OVERMARS, K.P., HUIGEN, M.G.A., de GROOT, W.T., VELDKAMP, A. Analysis of the effects of land use change on protected areas in the Philippines. Applied Geography, v.26, p.153-173, 2006.

VILLAÇA, F., Espaço Intra-Urbano no Brasil. São Paulo, Studio Nobel, 2001. 
WEGENER, M.; FÜRST, F.; Land-Use Transport Interation: State or Art. Publicação 46 (Berichte aus dem Institute für Raumplanung 46). Institute für Raumplanung, Universität Dortmund, Dortmund. 1999.

WEGENER, M.; GNAD, F.; VANNAHME, M.; The Time Scale of Urban Change. In Advances in Urban Systems Modelling, edited by Bruce Hutchinson and Michael Batty. Amsterdam: North Holland, 145-97, 1986.

XIMENES, A. C.; ALMEIDA, C. M.; AMARAL, S.; ESCADA, M. I. S.; AGUIAR, A. P. D. Modelagem Dinâmica do Desmatamento na Amazônia. Boletim de Ciências Geodésicas, v. 14, p. 370-391, 2008. 


\section{Apêndice A - Memorial para Modelagem}

O presente apêndice registra toda a sequência de passos realizados para a modelagem de cobertura e uso da terra em Guarulhos por meio do Dinamica-EGO, desde a conversão dos dados até a construção final do modelo. O objetivo é disponibilizar todos os procedimentos adotados ao longo da pesquisa realizada.

Os softwares utilizados foram o Arcgis 10.1, com licença proprietária, e Ilwis 3.8 e Dinâmica-EGO 3.0, com licença livre. E importante mencionar que o Arcgis 10.1 foi utilizado por mera familiaridade do autor, podendo ser facilmente substituído por outros programas, como por exemplo o Quantum Gis.

A sequência de passos foi dividida entre a Etapa A, com a preparação da base, e Etapa $B$, que diz respeito a construção dos modelos em si, conforme apresentado a seguir:

\section{Etapa A - Tratamento da base de dados}

1 - Conversão do sistema de coordenadas da base original para o sistema do projeto

2 - Consolidação das bases

2.1 - Verificação topológica dos shapes

2.2 - Correção geométrica e registro das imagens

3 - Elaboração dos mapas de cobertura e uso da terra

4 - Índice Kappa

5 - Extração de bases em Raster

5.1 - Conversão dos mapas shape para raster

5.2 - Criação dos mapas de distância

6 - Criação de um cubo de mapas

7 - Tabulação cruzada

7.1 - Processamento das bases

7.2 - Análise do Resultado

7.3 - Atribuição de classes para corrigir os valores

7.2 - Geração da base para realizar as estimativas de patcher, expander, área média e variância.

\section{Etapa B - Construção do modelo}

1 - Matriz de transição

2 - Pesos de evidência

3 - Modelo de transição com formação e expansão das manchas

4 - Validação por decaimento exponencial

5 - Projeção de cobertura e uso da terra 


\section{Etapa A - Preparação das Bases}

\section{1 - Conversão do sistema de coordenadas da base original para o sistema do projeto}

Uma vez que são realizados inúmeros procedimentos em que se mensuram as áreas e distâncias é preciso que as bases elas estejam em um sistema de coordenadas planas. Com isso, independente da origem dos dados ou do seu formato, as bases para o estudo foram convertidas para o sistema de coordenadas UTM com datum em WGS84.

O procedimento foi realizado no Arcgis $10.3 \mathrm{com}$ as ferramentas Project (para vetores) e Project Raster (para rasteres), ambos disponíveis em Data Management > Projections and Transformations.

\section{2 - Consolidação das bases}

\section{1 - Validação dos arquivos em formato shape}

Após a conversão dos dados, os shapes foram submetidos a uma análise da geometria por meio da ferramenta Check Geometry, disponível em Data Management > Features. A ferramenta verifica problemas de superposição de pontos em um polígono e os shapes que apresentaram problemas foram corrigidos manualmente.

Além disso, as bases foram submetidas a uma análise multicamadas, buscando adequar os limites externos, o traçado das vias que porventura apresentassem desvio e dos rios, obtendo assim maior coerência espacial entre as camadas. Este procedimento foi realizado manualmente com as ferramentas apropriadas para edição.

\section{2 - Ortorretificação, Georreferenciamento e Registro}

A imagem Ikonos apresentava um deslocamento de aproximadamente 75 metros, como pode ser observado na Figura A.2.1, a seguir. Para corrigir este problema foi realizado o registro da imagem, tomando por base as ortofotografias de Guarulhos de 2008 e bases cartográficas de detalhe. Com efeito, uma vez corrigida, a imagem Ikonos serviu de referência para o registro das aerofotografias de 1986, 1993 e 2000.

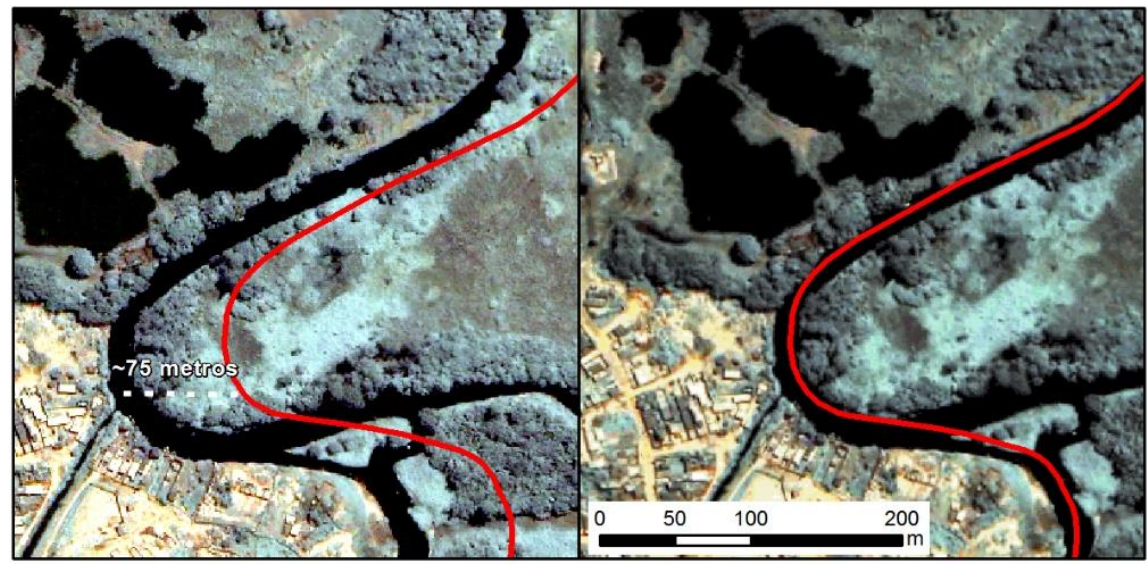

Figura A.2.1 - Correção geométrica da imagem Ikonos

\section{3 - Elaboração dos mapas de cobertura e uso da terra}


O mapa de cobertura e uso da terra para o ano de 2007 foi realizado por meio de sobreposição com a imagem Ikonos-2, sendo que os cortes dos polígonos foram feitos manualmente por meio da ferramenta Cut disponível no menu Editor. Após o recorte dos polígonos, as classes foram atribuídas manualmente.

As demais classificações foram feitas a partir dessa primeira, na ordem cronológica inversa, ou seja, 2000, 1993 e 1986, recortando-se e mudando-se as classes dos polígonos que sofreram transição em relação ao período anterior. É importante mencionar que com este procedimento, obteve-se uma base de cobertura e uso da terra multitemporal, na medida em que não se sobrepõem classes distintas sem que tenha ocorrido uma transição.

\section{4 - Índice Kappa}

Os pontos aleatórios foram gerados por meio do Arcgis $10.1 \mathrm{com}$ a ferramenta Create Random Points disponível em Data Management Tools > Feature Class. A cada classe foram atribuitos 50 pontos. Com o shape pronto, foram criadas três novas colunas, com formato tipo long: ID, Valor_Mapa, Valor_Ref. Na coluna ID foi inserida uma sequência de números em ordem crescente, de tal forma a não ter nenhum valor repetido. As demais colunas foram mantidas com valor nulo, a serem usadas nas etapas seguintes.

O valor do mapa de cobertura e uso da terra de 2007 foi obtido automaticamente por meio da ferramenta Intersect, disponível em Analysis Tools > Overlay. Foi realizada uma intersecção com o mapa de cobertura e uso da terra de 2007 e os resultado da operação foram transportados para o shape dos pontos aleatórios do pronto, no atribuito "Valor_Mapa". O passo final na preparação desta base, foi indicar a classe de cobertura e uso da terra, tomando como base as ortografias de 2008 , com maior resolução espacial, colocando tais valores na coluna do atributo "Valor_Ref".

O cálculo do índice Kappa foi realizado por meio de um script (Kappa Statistics) disponibilidade pela ESRI em seu site de compartilhamento, que pode ser acessado no endereço http://codesharing.arcgis.com. Neste script, após indicar o caminho do shape com os atributos obtidos no mapa a ser avaliado, é preciso indicar a primeira e a segunda observação, que nesta pesquisa se referem aos atributos Valor_Mapa e Valor_Ref, respectivamente. Os campos são apresentados na Figura A.4.1, a seguir. O resultado é apresentado na forma de uma tabela com os parâmetros de avaliação. 


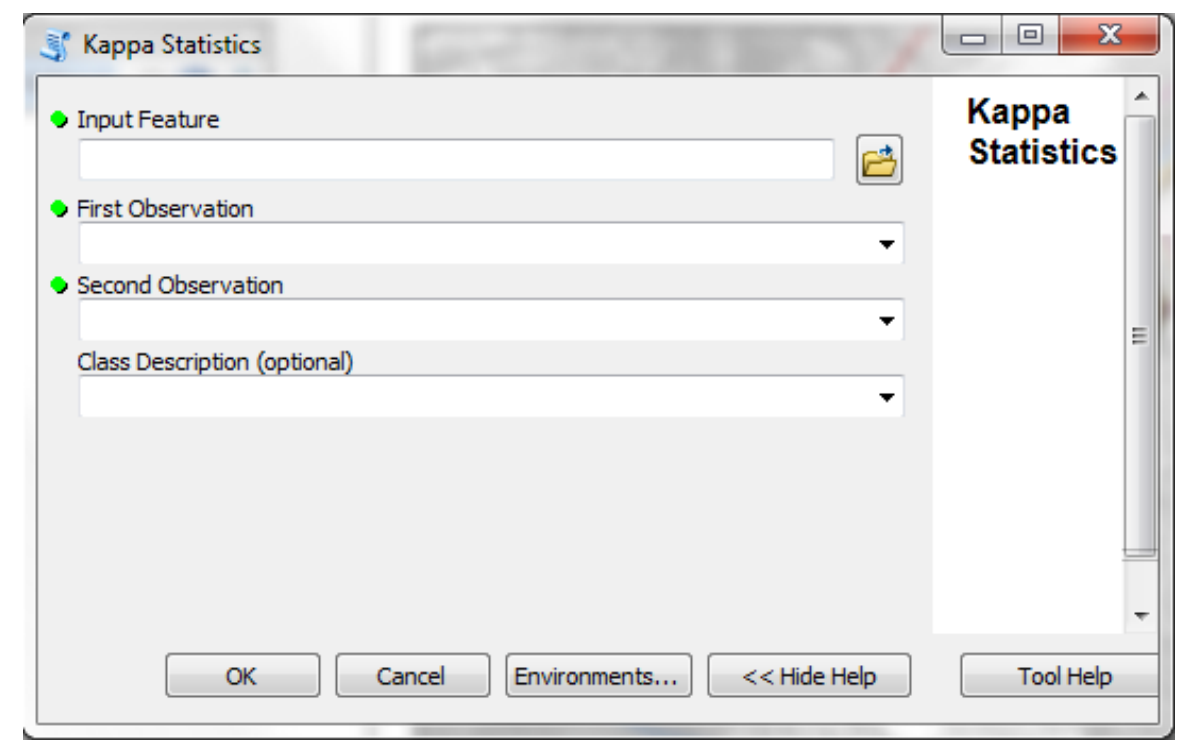

Figura A.4.1 - Janela do script Kappa Statistics.

\section{5 - Extração de bases em formato raster}

Todos os processamentos do Dinâmica-EGO são realizados sobre rasteres e com isso é necessário que todas as bases estejam neste formato. É preciso que todos eles tenham a mesma quantidade de linhas e colunas, resolução e coordenadas. A seguir são apresentados os passos para gerar, em raster, os mapas de cobertura e uso da terra, os mapas de distância e os métodos usados para corrigir o número de linhas e colunas quando necessário.

\section{1 - Variáveis categóricas}

Um aspecto importante é que o Dinamica-EGO trabalha apenas com valores numéricos em mapas categóricos. Com isso, é preciso criar no shape um novo atributo para atribuir um número a cada classe.

O procedimento é simples: Clicar com o botão direito no shape e depois em Open Atribute Table. No ícone Table Options ( short. Então basta atribuir os valores correspondentes. Não existe nenhum critério, basta que sejam anotados, pois a partir de então é com esses números que serão referidas as classes. A Figura A.5.1 indica as classes e valores usados na presente pesquisa.
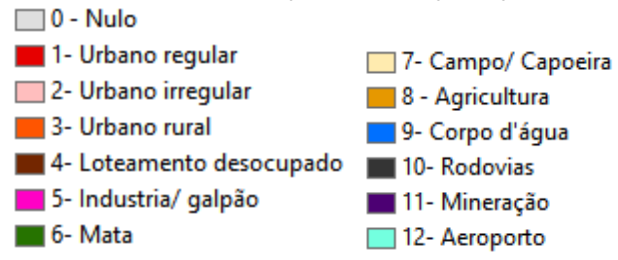

Figura A.5.1 - Valores inteiros atribuídos às classes dos mapas de cobertura e uso do solo.

Além disso, é importante que o arquivo shape possua um retângulo envolvente, que corresponderá aos limites de todas as camadas dos arquivos subsequentes. No caso do presente estudo, ele foi gerado usando a ferramenta para criação de retângulo da guia Editor e, em 
seguida, integrado ao conjunto de polígonos de cobertura e uso da terra. Outras ferramentas podem ser usadas para esse fim.

A conversão de shape para raster foi realizada por meio do Arcgis 10.1 com a ferramenta Polygon to Raster disponível em Conversion Tools > To Raster. Os parâmetros adotados estão apresentados na Figura A.5.2, a seguir.

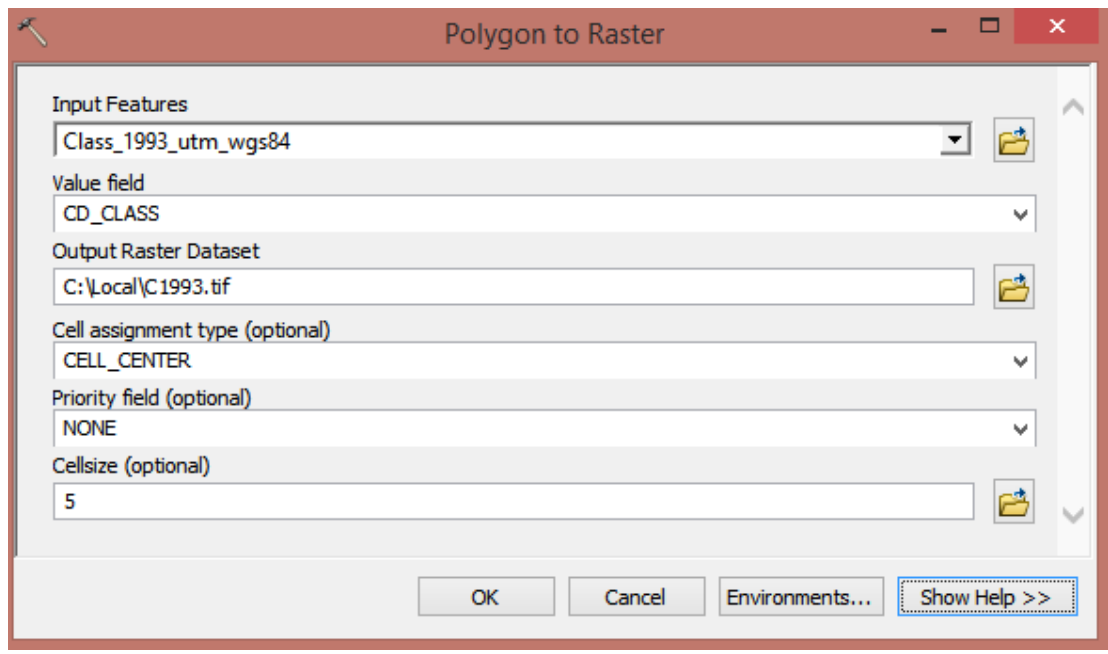

Figura A.5.2 - Janela da ferramenta Polygon to Raster.

A partir dessa primeira conversão foi gerada uma máscara por meio da ferramenta Raster Calculator, disponível em Spatial Analyst Tools > Map Algebra, na qual foi inserida a equação que consta na Figura A.5.3, a seguir.

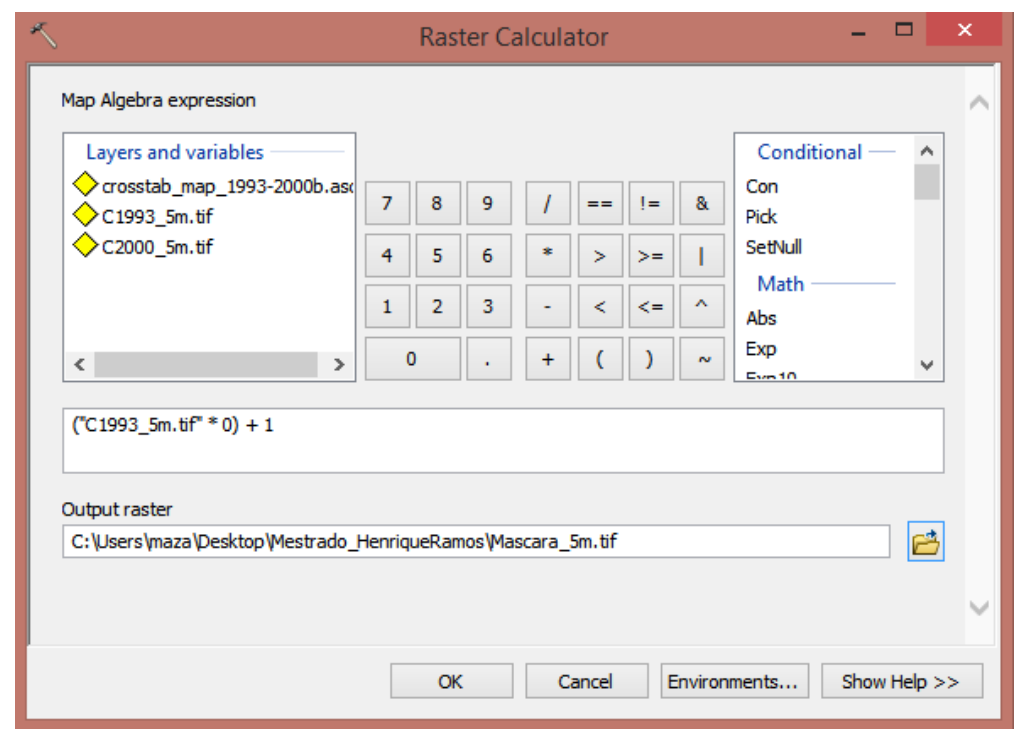

Figura A.5.3 - Janela da ferramenta Raster Calculator.

O resultado é uma máscara com a mesma quantidade de linhas e colunas e iniciada no mesmo ponto que a cobertura e uso da terra de 1986, porém com todos os valores de pixel igual a 1. A primeira vantagem de máscara é poder parametrizar os limites dos mapas de saída. Além disso, é importante se ter a máscara para corrigir pequenas inconsistências geométricas ou posicionais, muito comuns ao se usarem diferentes plataformas em etapas de manipulação, como será descrito mais adiante. 
Com isso, ao se abrir novamente a ferramenta Polygon to Raster para os três anos seguintes, clica-se em Environments e depois em Processing Extent, e escolhe-se na guia Extent a camada da máscara, conforme a Figura XX, a seguir. Como resultado, o ArcGIS produz a saída conforme estas coordenadas, mesmo que algum tipo de problema ocorra.

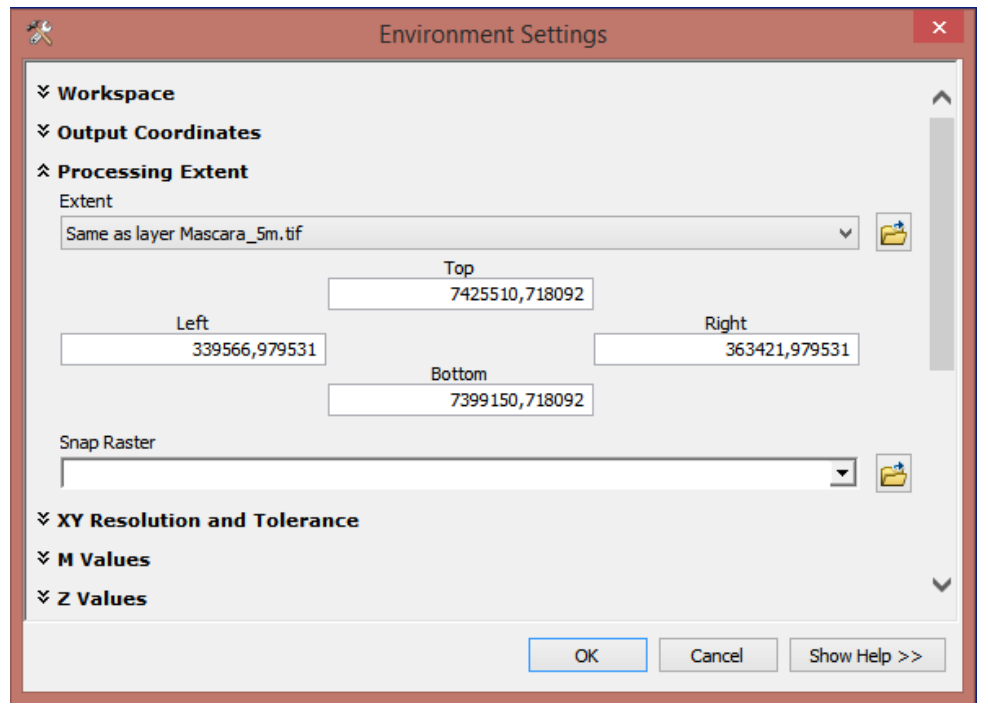

Figura A.5.4 - Janela da ferramenta Environment Settings.

\section{2 -Variáveis contínuas}

Os mapas de distância foram criados a partir das bases vetoriais previamente preparadas, nas quais foram exportadas apenas as feições de interesse, ou seja, as vias macrometropolitanas, vias estruturais, logradouros, aeroporto e acessos em arquivos distintos. Cada um deles foi submetido à ferramenta Euclidean Distance do Arcgis 10.1, disponível em Spatial Analyst Tools > Distance, em que os parâmetros principais foram preenchidos como indicado na Figura A.5.5, a seguir e, em seguida, clica-se em "Environments" e depois em "Processing Extent", e escolhe-se na guia "Extent" a camada da máscara. Como resultado o Arcgis gera a saída nestas coordenadas, ainda que algum tipo de problema ocorra.

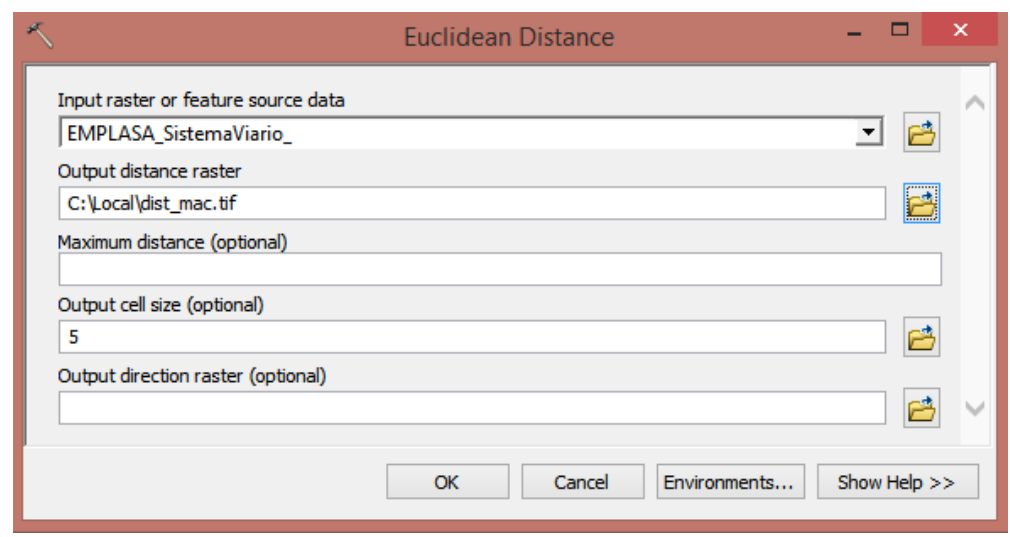

Figura A.5.5 - Janela da ferramenta Euclidean Distance.

5.3 - Verificação das bases em formato raster e alternativas para solução. 
A cada base criada, verifica-se a quantidade de linhas e colunas, resolução espacial e coordenadas do raster. Para isso basta clicar com o botão direito na camada, abrir a opção de propriedades, apontar a guia source, e verificar as linhas Columns and Rows, Cell Size $(x, y)$, Extent e Spatial Reference, conforme a Figura A.5.6, abaixo.

\begin{tabular}{|c|c|c|c|c|c|c|c|c|}
\hline General & Source & Key Metadata & Extent & Display & Symbology & Fields & \multicolumn{2}{|l|}{ Joins \& Relates } \\
\hline \multicolumn{4}{|c|}{ Property } & \multicolumn{4}{|c|}{ Value } & $\wedge$ \\
\hline \multicolumn{9}{|c|}{$\boxminus \quad$ Raster Information } \\
\hline \multicolumn{4}{|c|}{ Columns and Rows } & \multicolumn{4}{|c|}{4771,5272} & \\
\hline \multicolumn{4}{|c|}{ Number of Bands } & \multicolumn{4}{|c|}{1} & \\
\hline \multicolumn{4}{|c|}{ Cell Size $(X, Y)$} & \multicolumn{4}{|c|}{5,5} & \\
\hline General & Source & Key Metadata & Extent & Display & Symbology & Fields & Joins \& Relates & \\
\hline \multicolumn{3}{|c|}{ Property } & & \multicolumn{4}{|c|}{ Value } & $\wedge$ \\
\hline \multicolumn{9}{|c|}{$\square \quad$ Extent } \\
\hline \multicolumn{3}{|c|}{ Top } & & \multicolumn{4}{|c|}{7425510,71809} & \\
\hline \multicolumn{3}{|c|}{ Left } & & \multicolumn{4}{|c|}{339566,979531} & \\
\hline \multicolumn{3}{|c|}{ Right } & & \multicolumn{4}{|c|}{363421,979531} & \\
\hline \multicolumn{3}{|c|}{ Bottom } & & & \\
\hline \multicolumn{3}{|c|}{$\square \quad$ Spatial Reference } & & \multicolumn{4}{|c|}{ WGS_1984_UTM_Zone_23S } & \\
\hline
\end{tabular}

Figura A.5.6 - Janela Propriedades dos Raster.

Eventualmente pode acontecer de haver uma linha ou coluna a mais ou a menos ou ainda, pixels com tamanho incorreto, e mesmo uma coordenada incorreta por conta de arredondamento na saída do arquivo. Quando isso acontecer é possível corrigir o problema usando a calculadora raster ou a manipulação do arquivo ASCII.

\section{Calculadora raster}

É normalmente mais usado para correção do número de linhas ou colunas e adequação do tamanho do pixel. Basta realizar a multiplicação entre a base a ser corrigida e a máscara gerada na primeira etapa, além de ajustar em Environments os parâmetros de saída, conforme segue a equação apresentada na figura A.5.7, a seguir. O resultado deve conter o tamanho da máscara.

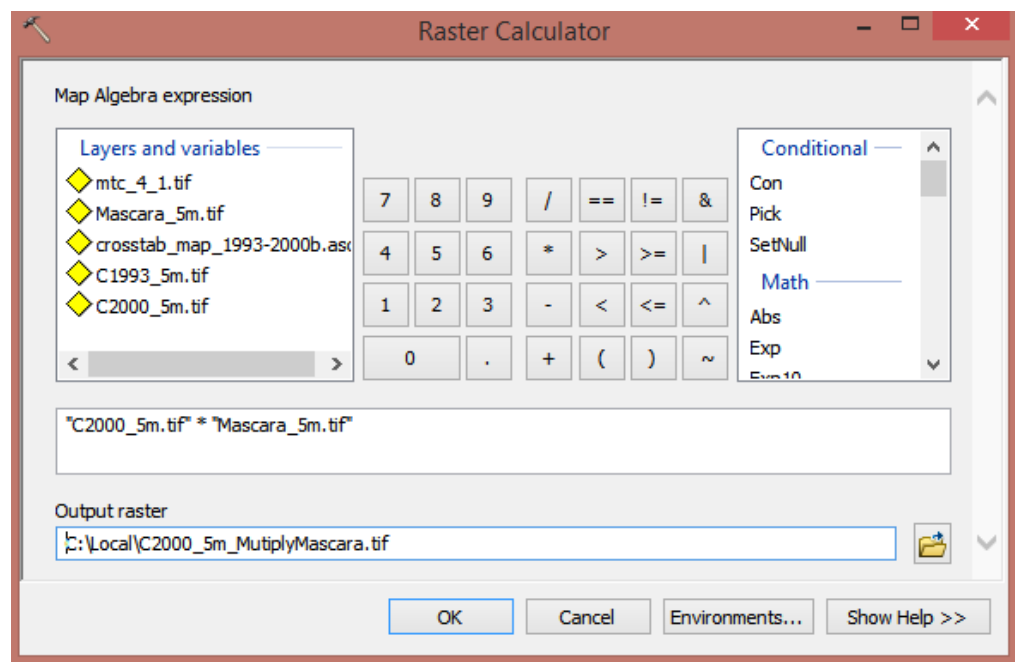

Figura A.5.7 - Janela da ferramenta Raster Calculator.

\section{Manipulação do arquivo ASCII}


Quando o problema se relaciona ao par de coordenadas, a melhor opção é resolver utilizando a manipulação em ASCII. Assim, basta seguir a seguinte sequência de passos:

- Converter o arquivo em ASCII por meio da ferramenta Raster to ASCII disponível em Conversion Tools > From Raster.

- Abrir o arquivo ASCII em um editor de texto, preferencialmente o Notepad ++, e verificar se o problema pode ter sido causado por uma simples questão de arredondamento.

- Alterar as linhas de coordenadas iniciais, conforme discriminado na Figura A.5.8 a seguir.
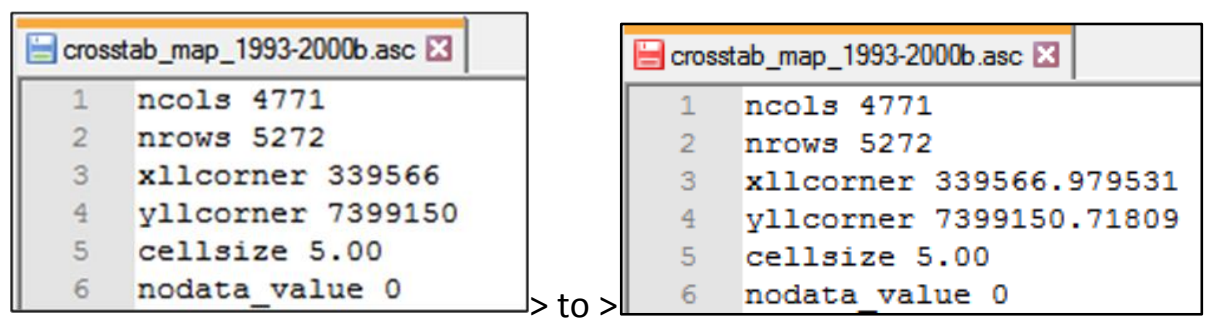

Figura A.5.8 - Edição do arquivo em ASClI.

Converter o arquivo em Geotiff por meio da ferramenta ASCIl to Raster disponível em Conversion Tools > To Raster.

\section{6 - Criação do cubo de mapas}

Para facilitar a manipulação das variáveis de entrada no Dinamica-EGO é recomendado utilizar o cubo de mapas, que nada mais é que um conjunto de bases "empilhadas" em um mesmo arquivo.

O Dinamica-EGO oferece uma ferramenta para criar um cubo de mapas: o functor Create Cube Map. Assim, montou-se um modelo de acordo com o apresentado na figura a seguir. Os mapas de distâncias foram carregados por meio do functor Load Map, ao passo que os mapas categóricos foram ser carregados com o functor Load Categorical Map. Cada um deles entrou em um functor Number and Name Map, onde foram inseridos os nomes que constarão no mapa de saída e a ordem deles, a partir de 0.

O mapa de saída se dá pela inserção do functor Save Map e deve ser preferencialmente no formato ERS, pois ele salva cada uma das camadas com o nome inserido no functor Number and Name Map. A Figura A.6.1 apresenta um pedaço do fluxo montado no software. 


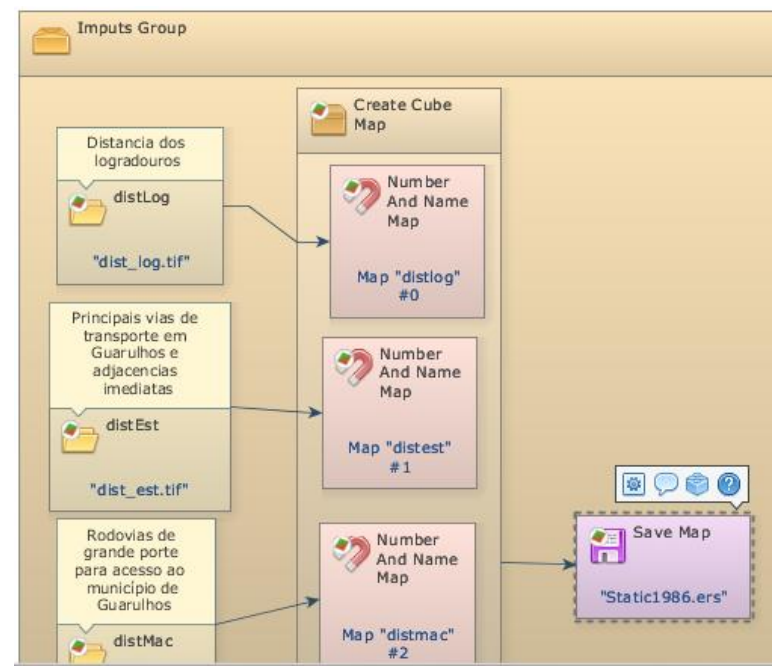

Figura A.6.1 - Fluxo de dados no Dinamica-EGO, entre os mapas de entrada e o cubo de mapas na saída.

\section{7 - Tabulação cruzada}

A tabulação cruzada serve a dois propósitos distintos. O primeiro deles é a eliminação de transições espúrias. Tais transições são especialmente comuns quando os mapas T0 e T1 têm origem em processamentos automáticos ou semiautomáticos, mas também podem acontecer nos mapeamentos realizados manualmente, ainda que em menor grau. Essas transições espúrias referem-se àquelas que, de fato, não ocorrem na realidade, como é o caso das transições Urbano > Mata e Aeroporto > Mata em Guarulhos. é importante mencionar que a não correção deste problema incorrerá na formação e expansão de manchas desconectadas com o ambiente real.

O segundo propósito se refere à conformação de uma base, que auxiliará o pesquisador a estimar os parâmetros de patcher, expander, área média e variância de tamanho de manchas (tanto originadas por expansão quanto por difusão) para cada transição, que servirão para alimentar o modelo. $O$ procedimento desta etapa é detalhada item a item, a seguir.

\section{1 - Processamento das bases}

Primeiramente é preciso importar os dados dos anos T0 e T1 no llwis. Utilizar a guia Operation Tree, e escolher dentro de Import/Export a ferramenta Import via GDAL, conforme a Figura A.7.1 abaixo. 


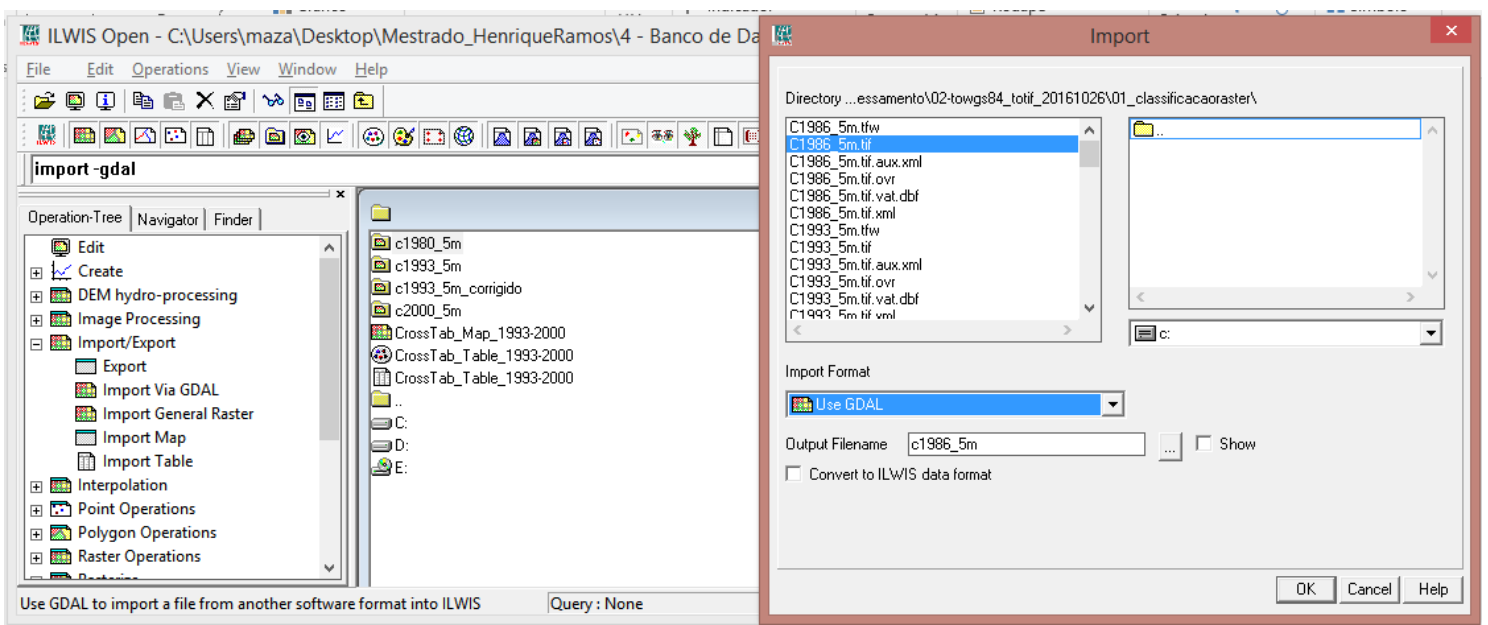

Figura A.7.1 - Janelas de importação e exportação de mapas no llwis.

Para gerar a tabulação cruzada é necessário abrir a ferramenta Cross, disponível dentro de Raster Operations na guia Operation-Tree, conforme figura abaixo. Nela também é possível observar que o preenchimento deve ter o mapa inicial em 1st Map, e final em 2nd Map, um nome de tabela deve ser informado (neste caso, CrossTab_Table_1993-2000) e clica-se na opção para gerar o mapa, e informando-se o nome dele (neste caso, CrossTab_Map_1993-2000). Em seguida clica-se em Show, conforme Figura A.7.2.

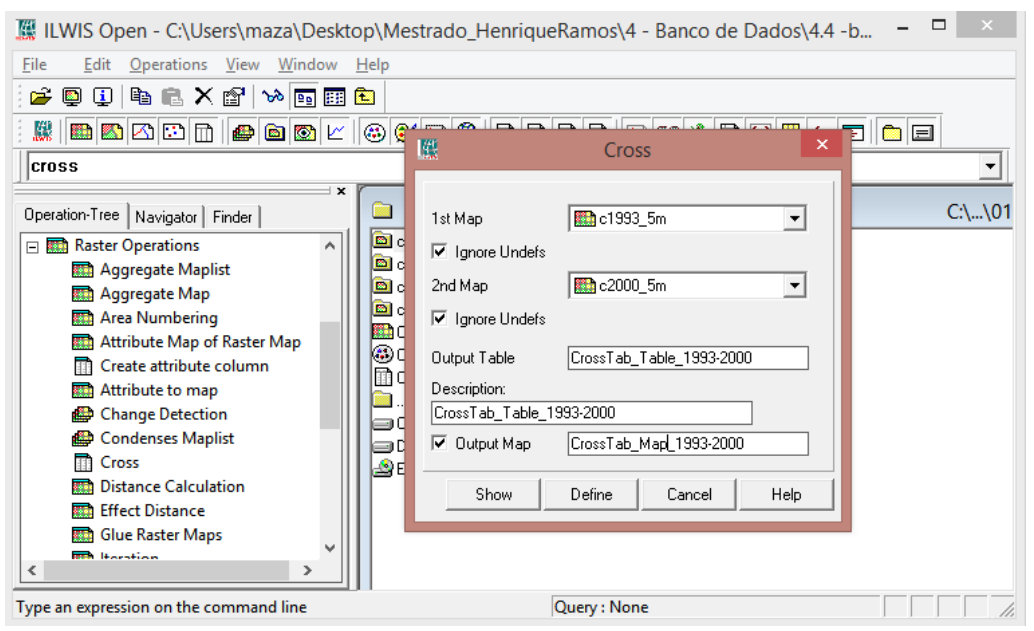

Figura A.7.2 - Janela de tabulação cruzada no llwis.

O tratamento do resultado foi realizado no Excel e no ArcGis. Para isso é preciso exportar a tabela e o mapa corretamente. Assim, novamente na caixa Import/Export e clicar duas vezes em Export. Seleciona-se na lista de bases o mapa a ser exportado, escolhe-se o formato Arc/Info ASCII .ASC e clica-se no botão com as reticências para se escolher a pasta de destino. Repete-se o procedimento com a tabela, escolhendo-se neste caso o formato DBF, conforme Figura A.7.3. 


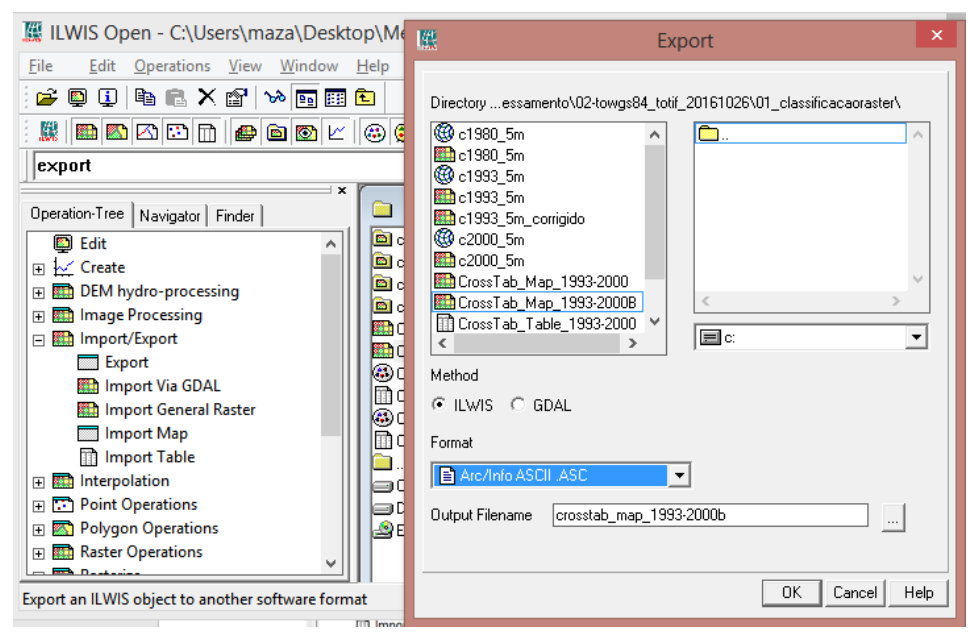

Figura A.7.3 - Janela de exportação de dados no Ilwis.

\section{2 - Análise do resultado}

Abre-se o mapa no ArcGIS. É possível verificar que a quantidade de classes foi aumentada. No exemplo abaixo, as 13 classes de origem passaram a 35 classes. Isso ocorre porque é gerada uma classe nova para cada transição, assim temos as 13 classes em situação de permanência (áreas em que não houve transições), mais 22 transições possíveis. A próxima etapa deverá elencar quais transições ocorreram de fato e quais são espúrias. Para isso, é preciso abrir o DBF no Excel, que deverá conter um arquivo com o aspecto da Figura abaixo. 


\begin{tabular}{|c|c|c|c|c|c|c|}
\hline & \multicolumn{2}{|l|}{ A } & $\mathrm{B}$ & c & D & $\mathrm{E}$ \\
\hline 1 & \multicolumn{5}{|c|}{ CROSSTAB_1 C1993_5N C2000_5I NPIX } & AREA \\
\hline 2 & \multicolumn{2}{|l|}{$0^{\circ} 0$} & 0 & 0 & 12408762 & 310219050 \\
\hline 3 & \multicolumn{2}{|l|}{$6^{\circ} 6$} & 6 & 6 & 5014558 & 125363950 \\
\hline 4 & \multicolumn{2}{|l|}{$7^{*} 7$} & 7 & 7 & 2338222 & 58455550 \\
\hline 5 & \multicolumn{2}{|l|}{$9 \cdot 9$} & 9 & 9 & 83841 & 2096025 \\
\hline 6 & \multicolumn{2}{|l|}{$3 \cdot 3$} & 3 & 3 & 144329 & 3608225 \\
\hline 7 & \multicolumn{2}{|l|}{$5^{*} 5$} & 5 & 5 & 710578 & 17764450 \\
\hline 8 & \multicolumn{2}{|l|}{$8^{\cdot} 8$} & 8 & 8 & 190250 & 4756250 \\
\hline 9 & $11^{*} 11$ & & 11 & 11 & 108010 & 2700250 \\
\hline 10 & $1^{*} 1$ & & 1 & 1 & 2330868 & 58271700 \\
\hline 11 & $6 \cdot 3$ & & 6 & 3 & 4426 & 110650 \\
\hline 12 & $4^{*} 4$ & & 4 & 4 & 753643 & 18841075 \\
\hline 13 & $4^{*} 1$ & & 4 & 1 & 338537 & 8463425 \\
\hline 14 & $7^{*} 5$ & & 7 & 5 & 11479 & 286975 \\
\hline 15 & $7^{* 1}$ & & 7 & 1 & 30320 & 758000 \\
\hline 16 & $4^{*} 5$ & & 4 & 5 & 85327 & 2133175 \\
\hline 17 & $6^{*} 7$ & & 6 & 7 & 8181 & 204525 \\
\hline 18 & $8^{*} 7$ & & 8 & 7 & 9577 & 239425 \\
\hline 19 & $6^{\circ} 4$ & & 6 & 4 & 1416 & 35400 \\
\hline 20 & $6^{*} 1$ & & 6 & 1 & 4841 & 121025 \\
\hline 21 & $2 \cdot 2$ & & 2 & 2 & 62870 & 1571750 \\
\hline 22 & $7^{*} 2$ & & 7 & 2 & 10802 & 270050 \\
\hline 23 & $8^{\circ} 4$ & & 8 & 4 & 1933 & 48325 \\
\hline 24 & $8^{*} 1$ & & 8 & 1 & 116 & 2900 \\
\hline 25 & $10 \cdot 10$ & & 10 & 10 & 90664 & 2266600 \\
\hline 26 & $7^{\cdot} 3$ & & 7 & 3 & 1745 & 43625 \\
\hline 27 & $4^{*} 7$ & & 4 & 7 & 1103 & 27575 \\
\hline 28 & $12 \cdot 12$ & & 12 & 12 & 387858 & 9696450 \\
\hline 29 & $4 \cdot 2$ & & 4 & 2 & 2892 & 72300 \\
\hline 30 & $4 \cdot 3$ & & 4 & 3 & 1371 & 34275 \\
\hline 31 & $5 \cdot 1$ & & 5 & 1 & 2391 & 59775 \\
\hline 32 & $1^{*} 5$ & & 1 & 5 & 280 & 7000 \\
\hline 33 & $7^{*} 4$ & & 7 & 4 & 8393 & 209825 \\
\hline 34 & $7^{\circ} 8$ & & 7 & 8 & 1399 & 34975 \\
\hline 35 & $5 \cdot 2$ & & 5 & 2 & 1477 & 36925 \\
\hline 36 & $4^{*} 6$ & & 4 & 6 & 253 & 6325 \\
\hline$\Delta$ & A & B & C & D & E & G \\
\hline 1 & CROSSTAB_ & C1993_5N & $2000 \_511$ & PIX & AREA & CLASSE \\
\hline 2 & $0^{\circ} 0$ & 0 & 0 & 12408762 & 310219050 & 1 \\
\hline 3 & $6^{\circ} 6$ & 6 & 6 & 5014558 & 125363950 & 2 \\
\hline 4 & $7 \cdot 7$ & 7 & 7 & 2338222 & 58455550 & 7 \\
\hline 5 & 9.9 & 9 & 9 & 83841 & 2096025 & 4 \\
\hline 6 & $3 \cdot 3$ & 3 & 3 & 144329 & 3608225 & 5 \\
\hline 7 & $5 \cdot 5$ & 5 & 5 & 710578 & 17764450 & 6 \\
\hline 8 & 8.8 & 8 & 8 & 190250 & 4756250 & 7 \\
\hline 9 & $111^{\circ} 11$ & 11 & 11 & 108010 & 2700250 & 8 \\
\hline 10 & $1 \cdot 1$ & 1 & 1 & 2330868 & 58271700 & 9 \\
\hline 11 & 6.3 & 6 & 3 & 4426 & 110650 & 10 \\
\hline 12 & $4^{\circ} 4$ & 4 & 4 & 753643 & 18841075 & 11 \\
\hline 13 & $4 \cdot 1$ & 4 & 1 & 338537 & 8463425 & 12 \\
\hline 14 & $7 \cdot 5$ & 7 & 5 & 11479 & 286975 & 13 \\
\hline 15 & $7 \cdot 1$ & 7 & 1 & 30320 & 758000 & 14 \\
\hline 16 & 4.5 & 4 & 5 & 85327 & 2133175 & 15 \\
\hline 17 & 6.7 & 6 & 7 & 8181 & 204525 & 16 \\
\hline 18 & 8.7 & 8 & 7 & 9577 & 239425 & 17 \\
\hline 19 & 6.4 & 6 & 4 & 1416 & 35400 & 18 \\
\hline 20 & 6.1 & 6 & 1 & 4841 & 121025 & 19 \\
\hline 21 & $2 \cdot 2$ & 2 & 2 & 62870 & 1571750 & 20 \\
\hline 22 & $7 \cdot 2$ & 7 & 2 & 10802 & 270050 & 21 \\
\hline 23 & $8^{\circ} 4$ & 8 & 4 & 1933 & 48325 & 22 \\
\hline 24 & 8.1 & 8 & 1 & 116 & 2900 & 23 \\
\hline 25 & $10 \cdot 10$ & 10 & 10 & 90664 & 2266600 & 24 \\
\hline 26 & $7 \cdot 3$ & 7 & 3 & 1745 & 43625 & 25 \\
\hline 27 & $4^{\circ} 7$ & 4 & 7 & 1103 & 27575 & 26 \\
\hline 28 & $12 \cdot 12$ & 12 & 12 & 387858 & 9696450 & 27 \\
\hline 29 & $4 \cdot 2$ & 4 & 2 & 2892 & 72300 & 28 \\
\hline 30 & $4 \cdot 3$ & 4 & 3 & 1371 & 34275 & 29 \\
\hline 31 & $5 \cdot 1$ & 5 & 1 & 2391 & 59775 & 30 \\
\hline 32 & 1.5 & 1 & 5 & 280 & 7000 & 31 \\
\hline 33 & $7 \cdot 4$ & 7 & 4 & 8393 & 209825 & 32 \\
\hline 34 & $7 \% 8$ & 7 & 8 & 1399 & 34975 & 33 \\
\hline 35 & $5 \cdot 2$ & 5 & 2 & 1477 & 36925 & 34 \\
\hline 36 & $4^{*} 6$ & 4 & 6 & 253 & 6325 & 35 \\
\hline
\end{tabular}

Na coluna A (CrossTab_...) está a classe gerada por tabulação cruzada; na coluna $B$ (C1993_5m), está a classe atribuída ao ano de 1993; na coluna C (C1200_5m), está a classe atribuída ao ano de 2000; na coluna D (NPIX), está o número de pixels nesta condição, e na coluna E (AREA), a área referente a eles. Assim, as linhas que têm o mesmo valor nas colunas $B$ e $C$ indicam que não houve transição; as linhas com valores diferentes indicam que houve transição. A correção da base está em manter o valor da coluna $\mathrm{C}$ apenas quando este estiver correto.

Como o formato ASCII do mapa não permite texto como valor de pixel (por exemplo, o texto " 0 * 0 " da célula A2), o Idrisi atribui o valor inteiro " 1 " para a primeira transição, "2" para a segunda, e assim por diante. O primeiro passo é, portanto, adicionar uma nova coluna "ID" e preencher com esses números nesta ordem. Assim, é possível relacionar as 35 classes da tabela com as 35 classes no mapa.

Em seguida, é preciso criar a coluna CLASSE e avaliar a possibilidade da transição existir efetivamente. Quando os valores são iguais nas colunas B e C, basta copiar o valor para a coluna CLASSE; quando eles são diferentes, é preciso ponderar se a transição é pertinente. No caso apresentado, o único erro ocorreu na linha 36 , em que um pequeno número de pixels apresentou a transição de Loteamento Desocupado para Mata. Isso ocorreu durante a conversão do polígono para raster e se configura em um erro. Na reclassificação, será mantido o valor 4, isto é, permanência da classe Loteamento Desocupado. 


\section{3 - Atribuição de classes para corrigir os valores}

Com os valores corretos atribuídos a cada uma das 35 classes, foi utilizada a ferramenta Reclassify do Arcgis, disponível na guia Reclass dentro de Spatial Analyst Tools. Ali basta selecionar o mapa CrossTab, clicar em unique para se ter pares de valores e preencher conforme marcado na tabela, sendo que a coluna Old Values faz referência ao ID do Excel, e na coluna New Values, deverão ser inseridos os valores corretos para cada classe. Clica-se em Environments > Processing Extent e seleciona-se a camada da máscara, depois clica-se em Output Coordinates e seleciona-se a camada da máscara (pode ocorrer que o arquivo ASCII não tenha a referência de coordenadas). Salva-se o arquivo como TIF, inserindo-se uma informação para marcar que esta classificação foi corrigida, como C2000_corrigida.tif, por exemplo.

\section{2 - Matriz de transição por classe - MTC}

A próxima etapa é gerar os parâmetros que serão utilizados no modelo de formação e expansão de manchas do Dinamica-EGO. Para isso, é realizada uma análise sobre as matrizes de transição por classe, geradas para cada uma das transições.

Em primeiro lugar, foi realizada novamente a tabulação cruzada com o mapa original de $T_{0}$ e o mapa corrigido de $T_{1}$, e então ambos foram exportados. Novamente, foi adicionada uma coluna de ID no Excel, e as linhas foram numeradas com 1, 2, .., n, conforme a ordem. Novas colunas foram criadas, contendo os valores das transições possíveis, como $1>5,4>1,4>2,4>3$, $5>4$ e assim por diante.

Em cada transição, foi realizada a seguinte sequência de operações para reclassificação dos valores:

- $\quad$ se é a transição em si, atribui-se o valor 3 .

- se o valor da classe no mapa $T_{0}$ é igual ao valor de origem da transição analisada, atribuise o valor 2;

- se o valor da classe no mapa $T_{1}$ é igual ao valor de destino da transição analisada, atribuise o valor 1 ;

- todas as demais recebem o valor 0 .

A Figura A.7.4 a seguir mostra um trecho da tabela como exemplo.

\begin{tabular}{|c|c|c|c|c|c|c|c|c|c|c|c|c|c|}
\hline$\Delta$ & A & c & D & $\mathrm{F}$ & G & H & I & $\mathrm{J}$ & & K & M & $\mathrm{N}$ & \\
\hline 1 & CROSS_TABLE! & C1986_5M & C1993_5M_Corrigido & NPIX & AREA & ID & $1>5$ & $4>1$ & $4>2$ & $4>3$ & $4>5$ & $5>4$ & 5> \\
\hline 2 & $0 * 0$ & 0 Vazio & 0 Vazio & 12408762 & 310219050 & 1 & & 0 & 0 & 0 & 0 & 0 & 0 \\
\hline 3 & $6 * 6$ & 6 Mata & 6 Mata & 5032529 & 125813225 & 2 & & 0 & $\overrightarrow{0}$ & 0 & 0 & 0 & 0 \\
\hline 4 & $7 * 7$ & 7 Campo / Capoeira & 7 Campo / Capoeira & 2366182 & 59154550 & 3 & & 0 & 0 & 0 & 0 & 0 & 0 \\
\hline 5 & $9 * 9$ & 9 Corpo D'água & 9 Corpo D'água & 80561 & 2014025 & 4 & & 0 & 0 & 0 & 0 & 0 & 0 \\
\hline 6 & $6 * 7$ & 6 Mata & 7 Campo / Capoeira & 19477 & 486925 & 5 & 5 & 0 & 0 & 0 & 0 & 0 & 0 \\
\hline 7 & $3 * 3$ & 3 Urbano Rural & 3 Urbano Rural & 78438 & 1960950 & & & 0 & 0 & 0 & 1 & 0 & 0 \\
\hline 8 & $5 * 5$ & 5 Industria/ Galpao & 5 Industria/ Galpao & 190699 & 4767475 & & 7 & 1 & 0 & 0 & 0 & 1 & 2 \\
\hline 9 & $8 * 8$ & 8 Agricultura & 8 Agricultura & 143388 & 3584700 & 8 & & 0 & 0 & 0 & 0 & 0 & 0 \\
\hline 10 & $11 * 11$ & 11 Mineração & 11 Mineração & 84291 & 2107275 & 9 & & 0 & 0 & 0 & 0 & 0 & 0 \\
\hline 11 & $7 * 11$ & 7 Campo / Capoeira & 11 Mineração & 23719 & 592975 & 10 & & 0 & 0 & 0 & 0 & 0 & 0 \\
\hline 12 & $4 * 3$ & 4 Loteamento Desocupado & 3 Urbano Rural & 59786 & 1494650 & 11 & & 0 & 2 & 2 & 3 & 2 & 0 \\
\hline & $1 * 1$ & 1 IIrhann Regular & 1 IIrhann Regular & 1687594 & $\Delta 318985 n$ & 12 & & , & 1 & n & n & n & n \\
\hline
\end{tabular}

Figura A.7.4 - Tabela com as transições de classe. 
A Equação A.7.1 foi utilizada no Excel para automatizar a reclassificação da tabela da Figura A.7.4:

$$
\begin{aligned}
& =S E(E(\$ B 2=E S Q U E R D A(J \$ 1 ; 1) * 1 ; \$ D 2=D I R E I T A(J \$ 1 ; 1) * 1) ; 3 ; S E \\
& (\$ B 2=E S Q U E R D A(J \$ 1 ; 1) * 1 ; 2 ; S E(\$ D 2=D I R E I T A(J \$ 1 ; 1) * 1 ; 1 ; 0)))
\end{aligned}
$$

Equação A.7.1 - Exemplo de equação a ser utilizada no Excel.

Com isso, seguiram-se os passos com a ferramenta Reclassify para se gerar um novo raster para cada transição, como o apresentado abaixo. A matriz de transição para a classe $4>1$ (coluna J) indica a transição de Loteamento Desocupado para a classe Urbano Regular. $O$ resultado é apresentado na Figura A.7.5 a seguir:

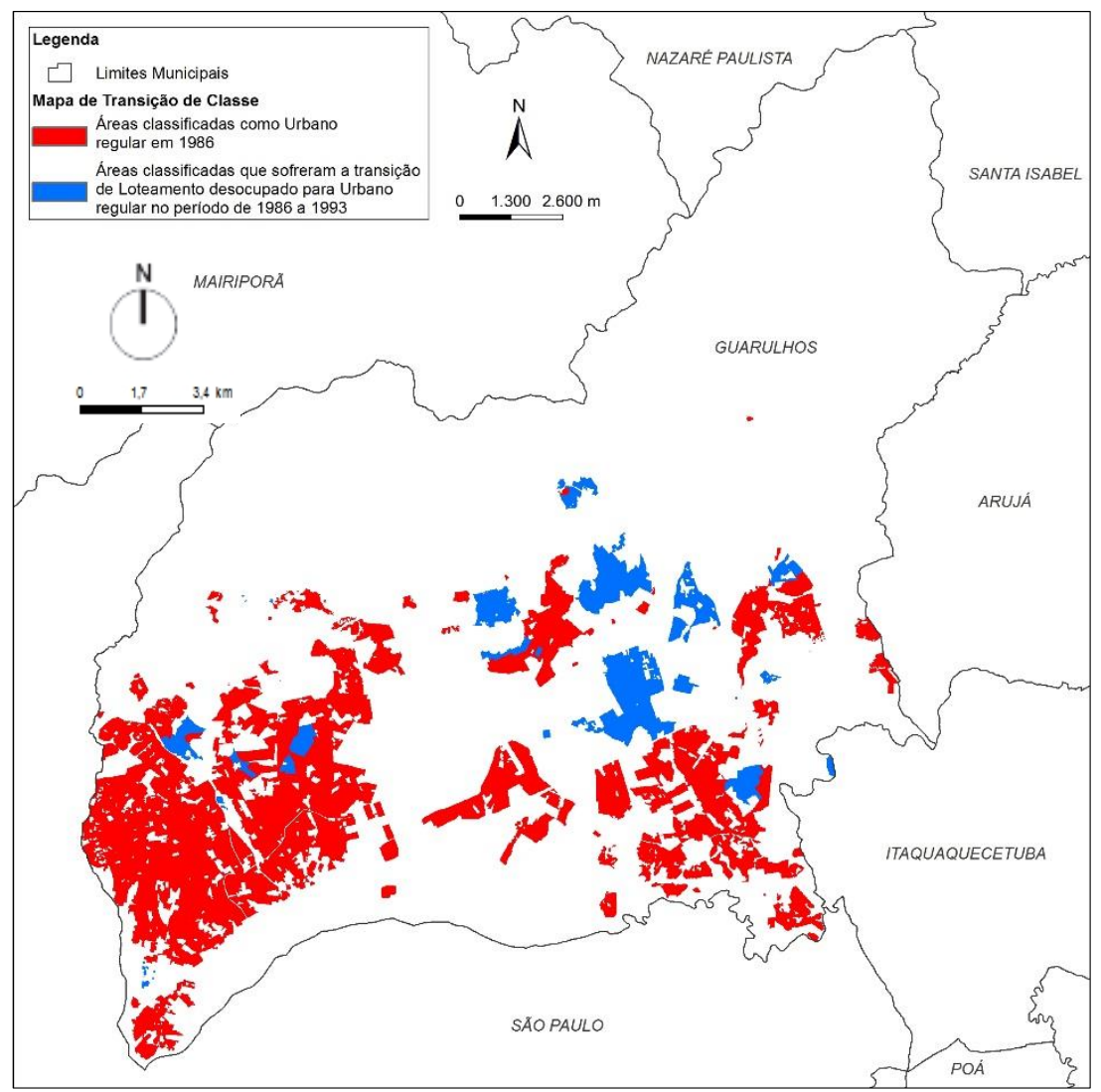

Figura A.7.5 - Mapa de transição de classe.

As classes de interesse são as de número 1 e 3 , e de fato, sendo que as demais poderiam ser unificadas para destacar apenas as classes 1 e 3 . A interpretação é a seguinte: as manchas $v$ representam a totalidade das classes de áreas urbanas regulares existentes em $T_{0}$ ao passo que as manchas azuis representam as transições de interesse, ou seja, os locais que eram Loteamento Desocupado no $T_{0}$ e passaram a Urbano Regular em $T_{1}$. Além disso, as manchas azuis que estão em contato com as vermelhas se formaram por expansão, o que no modelo corresponderá ao valor do algoritmo de alocação de transição expander, ao passo que as manchas azuis isoladas surgiram por formação de mancha (ou difusão), que no modelo corresponderá ao patcher. Assim, é preciso estimar para cada transição a porcentagem que deve ser atribuída a cada parâmetro, ou seja, quanto dessa transição especificamente foi formada por expansão das manchas e quanto foi formado por formação de novas manchas. 
É importante destacar que há duas formas de se resolver isso, e ambas serão apenas um ponto de partida, ou seja, independentemente do método adotado, é importante se ter em mente que posteriormente os parâmetros serão alterados no processo de validação. As duas são detalhadas na seção a seguir.

\section{3 - Extração dos parâmetros}

\subsection{1 - Parcial}

Os valores para patcher e expander são estimados visualmente, ou seja, os mapas são gerados conforme a Figura A.7.5, para cada uma das transições. No mapa acima, poder-se-ía estimar $35 \%$ para a função expander e $65 \%$ para a função patcher.

Após avaliarem-se todas as transições e atribuírem-se esses coeficientes, é preciso estimar os valores de área média, variância e índice de isometria. Para os dois primeiros, recorrese aos seguintes passos:

- Exportar o mapa Crosstab gerado na Etapa 7.1 para o formato shape por meio da ferramenta Raster to Polygon, disponível em Conversion Tools > From Raster. Desmarcar a opção para simplificar os polígonos.

- No shape gerado, abrir a tabela correspondente e criar uma coluna por meio de Add Field, com nome: Area_ha e type: Double.

- Clicar com o botão direito > Calculate Geometry > Area > Hectares.

- Clicar com o botão direito na coluna > Summarize. Na caixa 1, selecionar o nome do atributo de classe. Depois, na guia 2, localizar o atributo de área, clicar no sinal "+" e escolher Average e Variance. Então, selecionar um local para receber a tabela e clicar OK, conforme a Figura A.7.6.

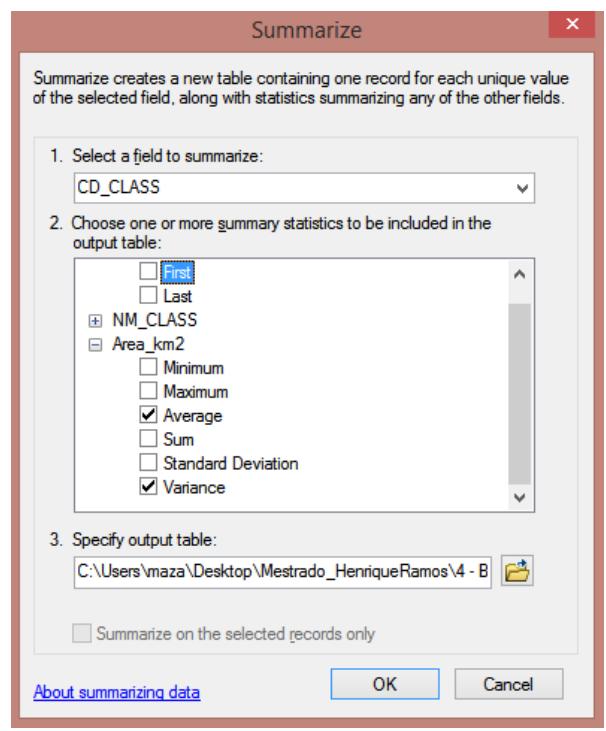

Figura A.7.6 - Janela de seleção da função Summarize.

Por fim, a isometria define o formato das manchas. Normalmente, para classes urbanas, é atribuído o valor 1,5. Quanto mais esse valor se aproxima de 2, mais o aspecto da mancha se torna geometricamente estável, isto é, compacto. 
Bastará então preencher uma tabela como a apresentada a seguir e reserva-la para a etapa de modelagem:

\begin{tabular}{|c|c|c|c|c|}
\hline Expander & Patcher & Área Média & Variância & Índice de Isometria \\
\hline 0.35 & 0.65 & 560 & 234 & 1.5 \\
\hline
\end{tabular}

Tabela A.7.1 - Parâmetros para a modelagem

\subsection{2 - Completo}

No modo melhorado, os valores de patcher e expander são calculados diretamente na base, com valores exatos. Além disso, o cálculo de área média, variância, ambos fornecidos em hectares (ha), e índice de isometria são estimados para as áreas que sofreram formação ou expansão das manchas.

Para isso, todos os mapas MTC devem ser convertidos em shape, conforme descrito na Seção 7.3.1 do Apêndice A, e a ele deve ser criada uma coluna de atributos chamada "Touch_2", com valor short. Uma consulta espacial deve ser conduzida para separar os polígonos da classe 3 que tocam os polígonos com da classe 2 . E deverão ser marcados com o valor " 1 ". Para auxiliar nesta etapa, foi criado um script para ArcGIS que automatiza esta parte do procedimento, e está disponibilizado no Apêndice $B$.

No shape gerado, abre-se a tabela correspondente e cria-se uma coluna por meio de Add Field, com nome: Area_ha e type: Double.Os procedimentos são os seguintes:

- Clicar com o botão direito > Calculate Geometry > Area > Hectares.

- Calcular a área para os polígonos que tocam os polígonos da classe 2 e os que não tocam, e calcular as porcentagens para se obterem, respectivamente, os valores de expander e patcher.

- Clicar com o botão direito no Shape e depois em Properties. Em Definition Query, criar a seguinte query: "Touch_2" = 1 .

- Clicar com o botão direito na coluna > Summarize. Na guia 1, selecionar o nome do atributo de classe. Depois, na guia 2, localizar o atributo de área, clicar no sinal "+" e escolher Average e Variance para o parâmetro expander.

- Repetir o procedimento para a query "Touch_2" $=0$ e preencher os dados para o parâmetro patcher.

Por fim, o índice de isometria se refere ao formato das manchas. Normalmente, para classes urbanas, é atribuído o valor 1,5. Quanto mais esse valor se aproxima de 2, mais o aspecto da mancha se torna geometricamente estável, isto é, compacto.

Bastará então preencher uma tabela como a apresentada a seguir e reserva-la para a etapa de modelagem:

\begin{tabular}{|c|c|c|c|c|c|c|c|c|}
\hline Transição & Expander & Patcher & \multicolumn{3}{|c|}{ Expander } & \multicolumn{3}{c|}{ Patcher } \\
\hline $4>1$ & 0.278 & 0.722 & Área Média & Variância & Isometria & Área Média & Variância & Isometria \\
\cline { 4 - 8 } & & & 234 & 243 & 1.5 & 430 & 590 & 1.5 \\
\hline
\end{tabular}

Tabela A.7.2 - Parâmetros para a modelagem 


\section{Etapa B - Construção do modelo}

A construção do modelo para o projeto seguiu as indicações da documentação oficial, e são apresentadas nas seções a seguir as figuras com os modelos gerados.

1 - Matriz de transição

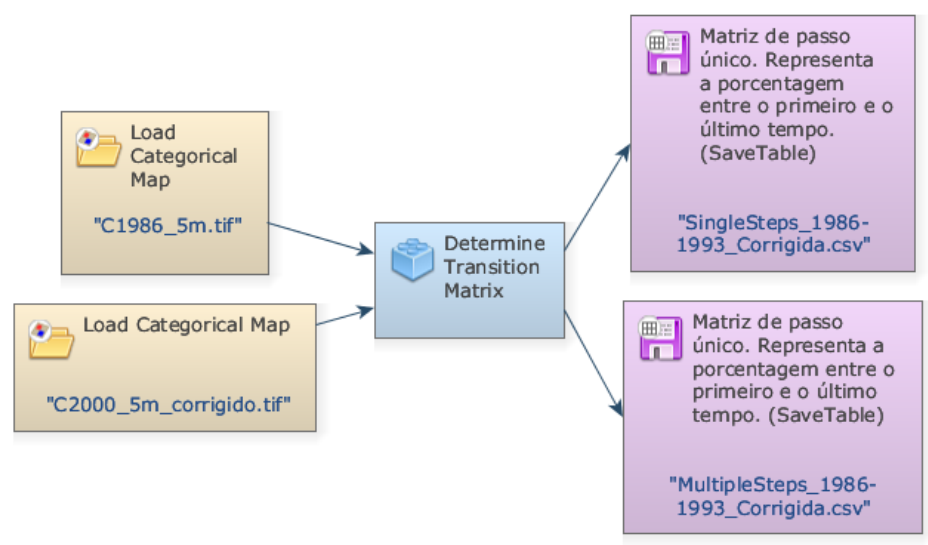

Figura B.1 - Entradas e saídas para a geração das matrizes de transição.

2 - Pesos de evidência

$\mathrm{O}$ arquivo pesos de evidência contém quatro passos integrados. No primeiro deles, é gerado o esqueleto com as faixas de distância para cada um dos mapas. No passo seguinte, este esqueleto é preenchido com os pesos de evidência para cada faixa da variável em cada transição. O passo três prepara a análise de correlação entre as variáveis e, por fim, no passo quatro, é gerado o mapa de probabilidade de transição para cada uma das transições.

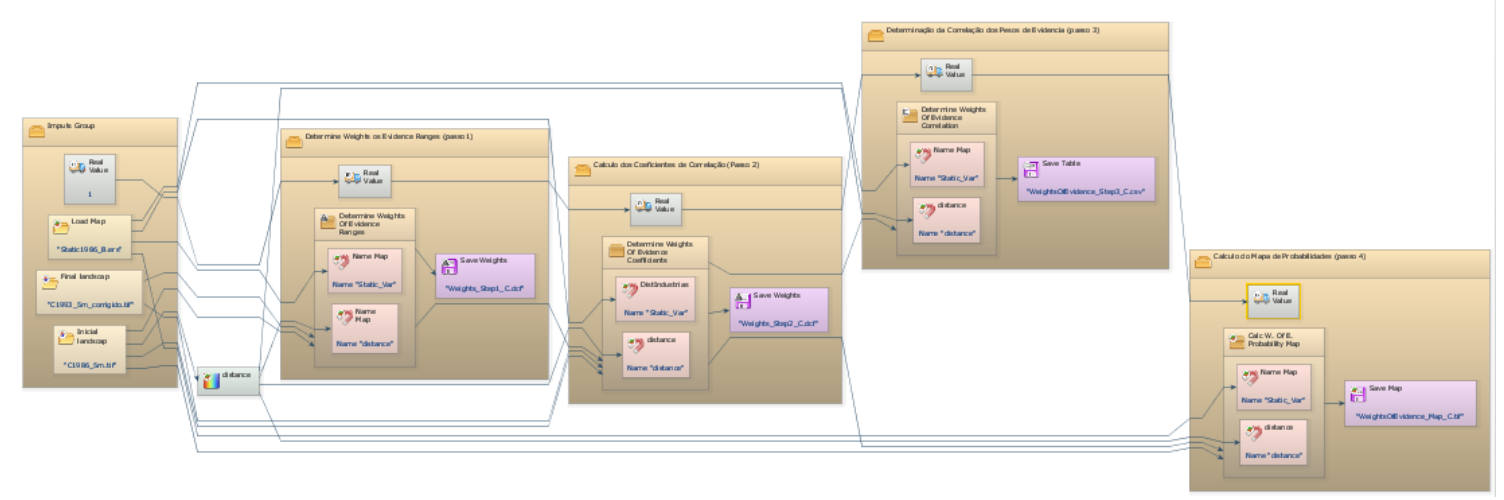

Figura B.2 - Entradas e saídas para a geração dos pesos de evidência.

A análise dos resultados deve passar pela verificação do conteúdo da tabela no passo três, apresentada na Figura xx a seguir. Nela é possível observar a classe de origem, a classe de destino e o resultado da comparação de correlação entre a primeira e a segunda variável. Uma vez que o método de pesos de evidência tem como premissa o fato de as variáveis serem 
independentes, quando houver a correlação em um par de coordenadas, é preciso excluir uma delas (preferencialmente, a mais fracamente associada com a transição) ou integrá-las, gerando uma nova variável. O resultado mostra a possibilidade de correlação por meio de cinco índices distintos, a saber: Chi-Quadrado, Crammer, Contigência, Joint Entropry e Joint Uncertanly.

\begin{tabular}{|c|c|c|c|c|c|c|c|c|c|}
\hline \multicolumn{9}{|c|}{ Table } & $\mathrm{x}$ \\
\hline. .4 & Tra... & First_Variable* & Second_Variable* & Chi_2 & Crammer & Contingency & Joint_Entropy & Joint_Uncertainty & 田 \\
\hline 1 & 5 & Static_Var/altmts & Static_Var/distacess & $1711990 \ldots$ & $0.337225 \ldots$ & $0.6368559 \ldots$ & $2.95942245742 \ldots$ & $0.22509874550 \ldots$ & $\mathbf{A}$ \\
\hline 1 & 5 & Static_Var/altmts & Static_Var/distaer & $5356200 \ldots$ & $0.190099 \ldots$ & $0.4221265 \ldots$ & $3.30007372912 \ldots$ & $0.07074919853 \ldots$ & \\
\hline 1 & 5 & Static_Var/altmts & Static_Var/distest & $4250191 \ldots$ & $0.168286 \ldots$ & $0.3811073 \ldots$ & $3.54768348797 \ldots$ & $0.04998951418 \ldots$ & \\
\hline 1 & 5 & Static_Var/altmts & Static_Var/distlog & $2354956 \ldots$ & $0.126853 \ldots$ & $0.2967311 \ldots$ & $3.30964346336 \ldots$ & $0.02951710403 \ldots$ & \\
\hline 1 & 5 & Static_Var/altmts & Static_Var/distmac & $1205597 \ldots$ & $0.283250 \ldots$ & $0.5700487 \ldots$ & $3.63393352773 \ldots$ & $0.12344949943 \ldots$ & \\
\hline 1 & 5 & Static_Var/altmts & Static_Var/slpperc & $9780138 \ldots$ & $0.267149 \ldots$ & $0.5475629 \ldots$ & $3.67555262116 \ldots$ & $0.11632286789 \ldots$ & \\
\hline 1 & 5 & Static_Var/altmts & distance/distance_t... & $3049295 \ldots$ & $0.246507 \ldots$ & $0.3291847 \ldots$ & $2.07780295249 \ldots$ & $0.06702295498 \ldots$ & \\
\hline 1 & 5 & Static_Var/altmts & distance/distance_t... & $6538624 \ldots$ & $0.208407 \ldots$ & $0.4546738 \ldots$ & $3.47926272018 \ldots$ & $0.07687344333 \ldots$ & \\
\hline 1 & 5 & Static_Var/distacess & Static_Var/distaer & $1472068 \ldots$ & $0.176876 \ldots$ & $0.6105834 \ldots$ & $2.87394689217 \ldots$ & $0.21528377705 \ldots$ & \\
\hline 1 & 5 & Static_Var/distacess & Static_Var/distest & $7223479 \ldots$ & $0.138582 \ldots$ & $0.4729160 \ldots$ & $3.29855867121 \ldots$ & $0.09316590874 \ldots$ & \\
\hline 1 & 5 & Static_Var/distacess & Static_Var/distlog & $1774138 \ldots$ & $0.085179 \ldots$ & $0.2600910 \ldots$ & 3.1395360077981 & $0.02353301770 \ldots$ & \\
\hline 1 & 5 & Statir Mar Idistaress & Statir Var/distmar & 1896423 & ก 189654 & ก 6559817 & 328914246367 & ก 21929353383 & \\
\hline
\end{tabular}

Figura B.3 - Índices para avaliação de correlação entre as variáveis.

No presente estudo, foi considerado o índice Joint Information Uncertainty, descrito em Bonham-Carter (1994). Assim, para cada par de variáveis analisado, foi verificado se o índice apresentava valor superior a 0,5 de associação ou dependência espacial. Quando isso acontecia, uma das variáveis era excluída, objetivando-se deixar apenas variáveis espacialmente independentes.

Além disso, o mapa de probabilidades deve ser usado para verificar se as variáveis utilizadas conseguiram delimitar corretamente as áreas com maiores probabilidades de transição para cada uma das classes. Isso pode ser feito ao adicionar o mapa de probabilidades, as novas áreas de uma determinada transição (classe 4 do mapa $\mathrm{mtc}$ ) e os mapas de distância calculados do cubo de mapas, como apresentado na Figura XX a seguir. O objetivo desta fase é tentar encontrar quais são as variáveis que determinam mais uma determinada transição. Sugere-se que na primeira vez em que se rodar o modelo, sejam usadas todas as variáveis disponíveis, e depois, no momento de revisão, esta análise de sobreposição seja realizada, para melhorar os resultados obtidos.

\section{3 - Modelo de transição com formação e expansão das manchas}




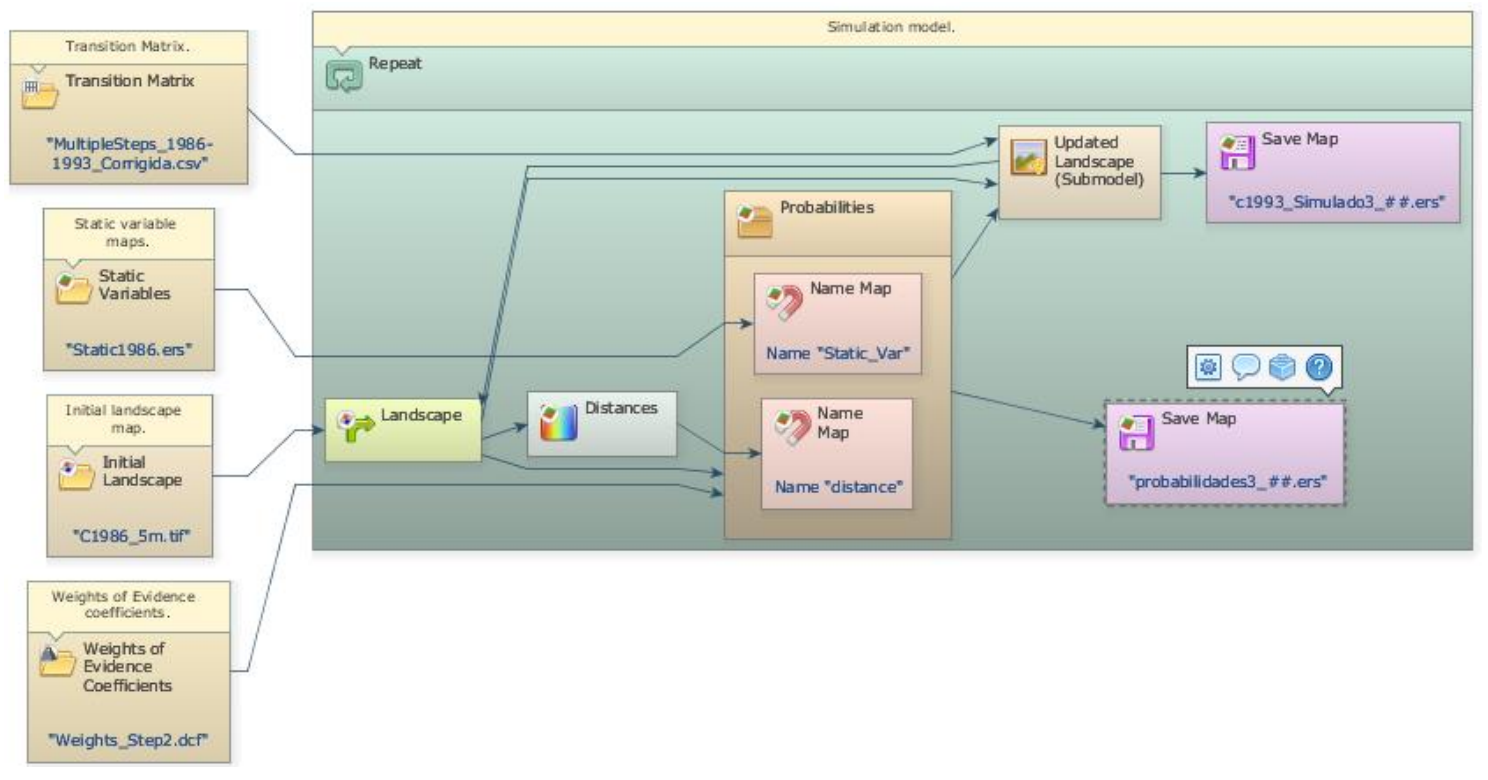

Figura B.4 - Entradas e saídas para a simulação do mapa de cobertura e uso da terra.

\section{4 - Validação por decaimento exponencial}

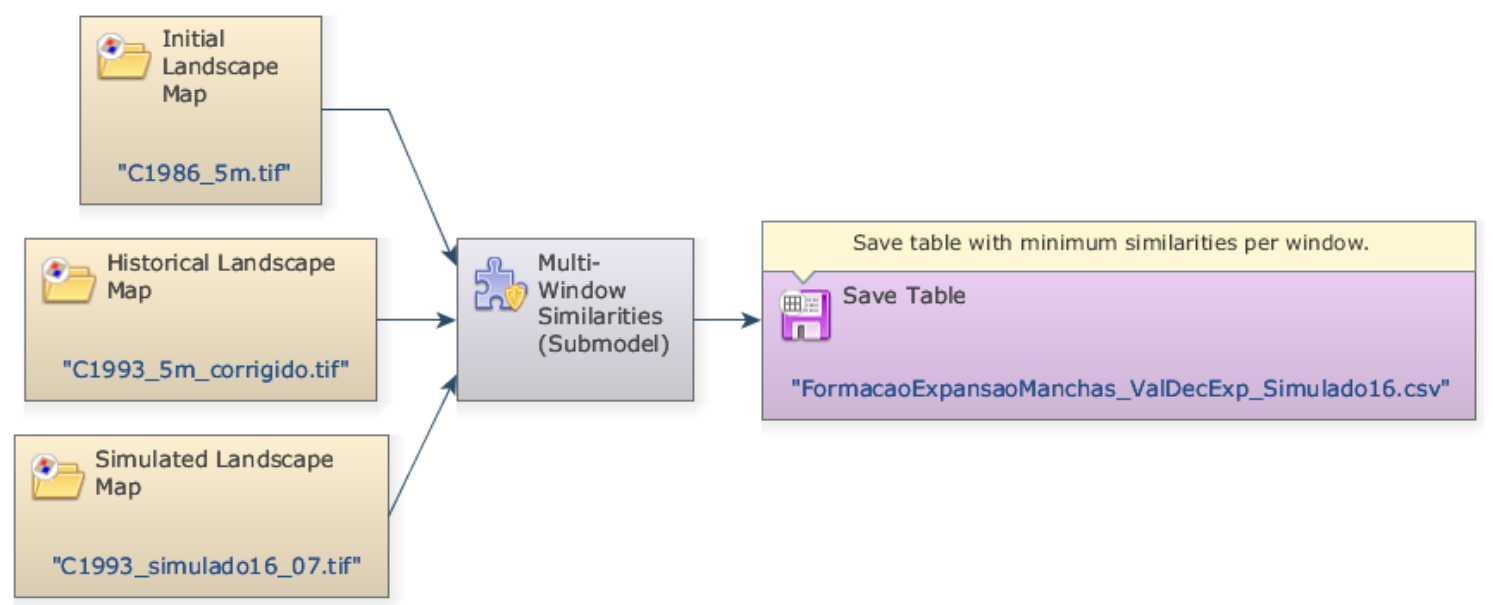

Figura B.5 - Entradas e saídas para a validação do mapa simulado. 


\section{Apendice B - Script para integrar a consulta por Atributos e Espacial}

O presente script realiza o seguinte conjunto de passos: Ao fornecer o caminho onde foram guardados os arquivos em raster com as classes $0,1,2$ e 3 em formato tiff, em que as classes de interesse são 1 e 3, conforme descrito na Seção 7.2 do apêndice $A$, o script converterá o raster em shape e realizará a consulta para saber quais são os polígonos da classe 3 que tocam a classe 1. Como resultado será criado, para cada arquivo raster na pasta de origem, um arquivo shape com a denominação NomeDoArquivo_Grid3.shp, o qual terá a indicado na coluna touch_1 o resultado da análise, marcando " 1 " para os polígonos que tocam e " 0 " quando não tocam. Além disso, também deixará uma tabela em DBF com estes resultados e o cálculo da área correspondente. $O$ shape servirá para o cálculo dos parâmetros de área média e variância em duas etapas, conforme descrito na Seção 7.3, ao passo que a proporção entre os polígonos que tocam a classe 1 e os que não a tocam, fornecerá os parâmetros de expander e patcher, respectivamente.

Para adicionar o script no Arcgis como ferramenta do Arctoolbox, é preciso copiar o texto indicado no script 1 em um editor de texto e salvar com o nome EstimatePatcherExpander. Posteriormente, é preciso localizar o arquivo na pasta correspondente e alterar a extensão do arquivo para py, ou seja, EstimatePatcherExpander.py. Este é o formato do Python, linguagem usada para compor o script.

A partir daí, basta clicar com o botão direito em um espaço livre do Arctoolbox em Add ToolBox. Então, clica-se no ícone New ToolBox e cria-se uma nova ToolBox na pasta de interesse com o nome de preferência. Feito isso, basta selecioná-la para adicioná-la em Arctoolbox.

No passo seguinte, é preciso clicar com o botão direito na Toolbox criada, e depois em $A d d>$ Script. Na janela que é aberta, copia-se "EstimatePatcherExpander" em Name e Label, e clica-se em Avançar.

Em "Script File", localiza-se a pasta onde o arquivo python foi salvo, seleciona-se o mesmo e clica-se em Avançar. Na guia de parâmetros, digita-se "Caminho de Origem" na primeira linha, e seleciona-se "Folder" na coluna seguinte. Na linha debaixo, digita-se "Caminho de Destino" e seleciona-se novamente "Folder" na coluna seguinte, conforme Figura B.1 abaixo. 


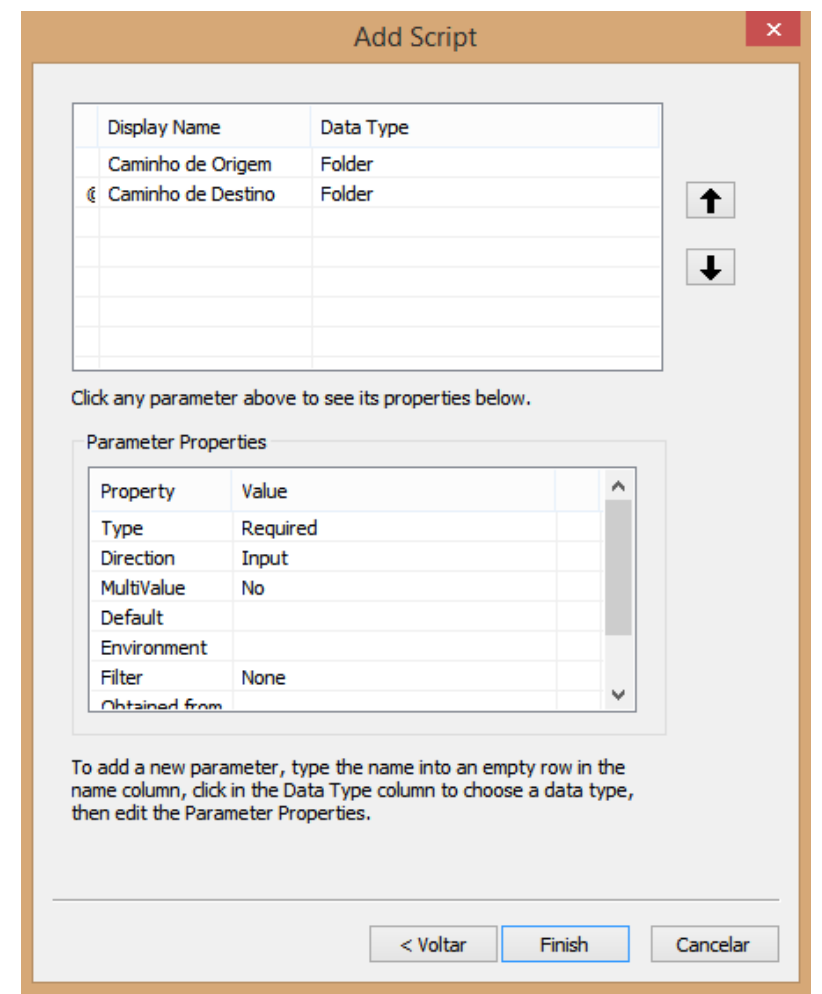

Figura B.6 - Janela para inserção das propriedades do script.

Feito isso basta clicar em Finish. A ferramenta é criada, e para usá-la basta clicar duas vezes sobre ela, que deve abrir como na figura abaixo. Para usar, é preciso indicar no primeiro campo a localização das figuras mtc, em formato tif, criadas na Seção 7.2 do Apêndice $A$, e no segundo campo a pasta de destino dos resultados pretendidos.

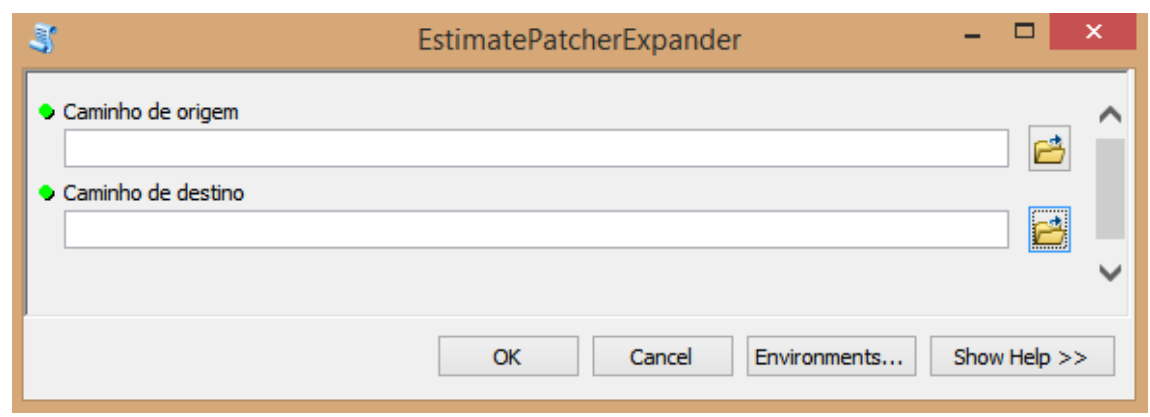

Figura B.7 - Ferramenta pronta para uso.

\section{Script 01}

\# Desenvolvido por Henrique Ramos em 04/2017

\# Realiza, em lote, a conversão para shape de um arquivo raster, e a consulta por atributo e espacial entre as classes 1 e 3

\# com proposito de estimar os parametro patcher e expander do software dinâmica-EGO

\# by: Maza

import arcpy, os

\#Le o local de origem e gera as linhas de endereço para cada arquivo tif path = arcpy.GetParameterAsText(0)

writeLog=open(path+"\FileListLog.txt","w") 


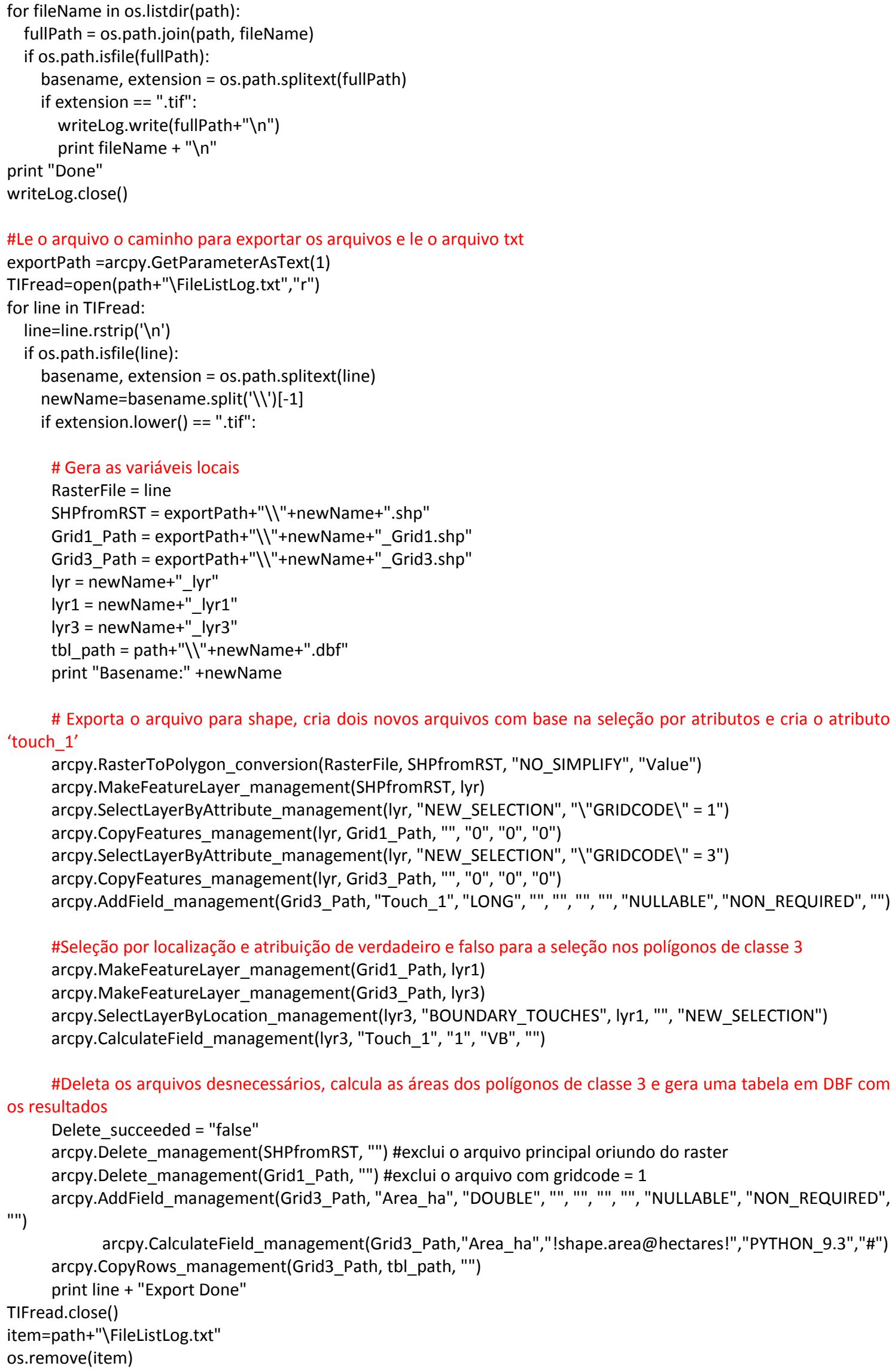

\#Deleta os arquivos desnecessários, calcula as áreas dos polígonos de classe 3 e gera uma tabela em DBF com os resultados

Delete_succeeded $=$ "false"

arcpy.Delete_management(SHPfromRST, "') \#exclui o arquivo principal oriundo do raster arcpy.Delete_management(Grid1_Path, "') \#exclui o arquivo com gridcode = 1

arcpy.AddField_management(Grid3_Path, "Area_ha", "DOUBLE", "', "'", "', "', "NULLABLE", "NON_REQUIRED", "')

arcpy.CalculateField_management(Grid3_Path,"Area_ha","!shape.area@hectares!","PYTHON_9.3","\#") arcpy.CopyRows_management(Grid3_Path, tbl_path, "'")

TIFread.close() print line + "Export Done"

item=path+"\FileListLog.txt" os.remove(item) 